\title{
The impact of diseases in dairy cows on greenhouse gas emissions and economic performance
}

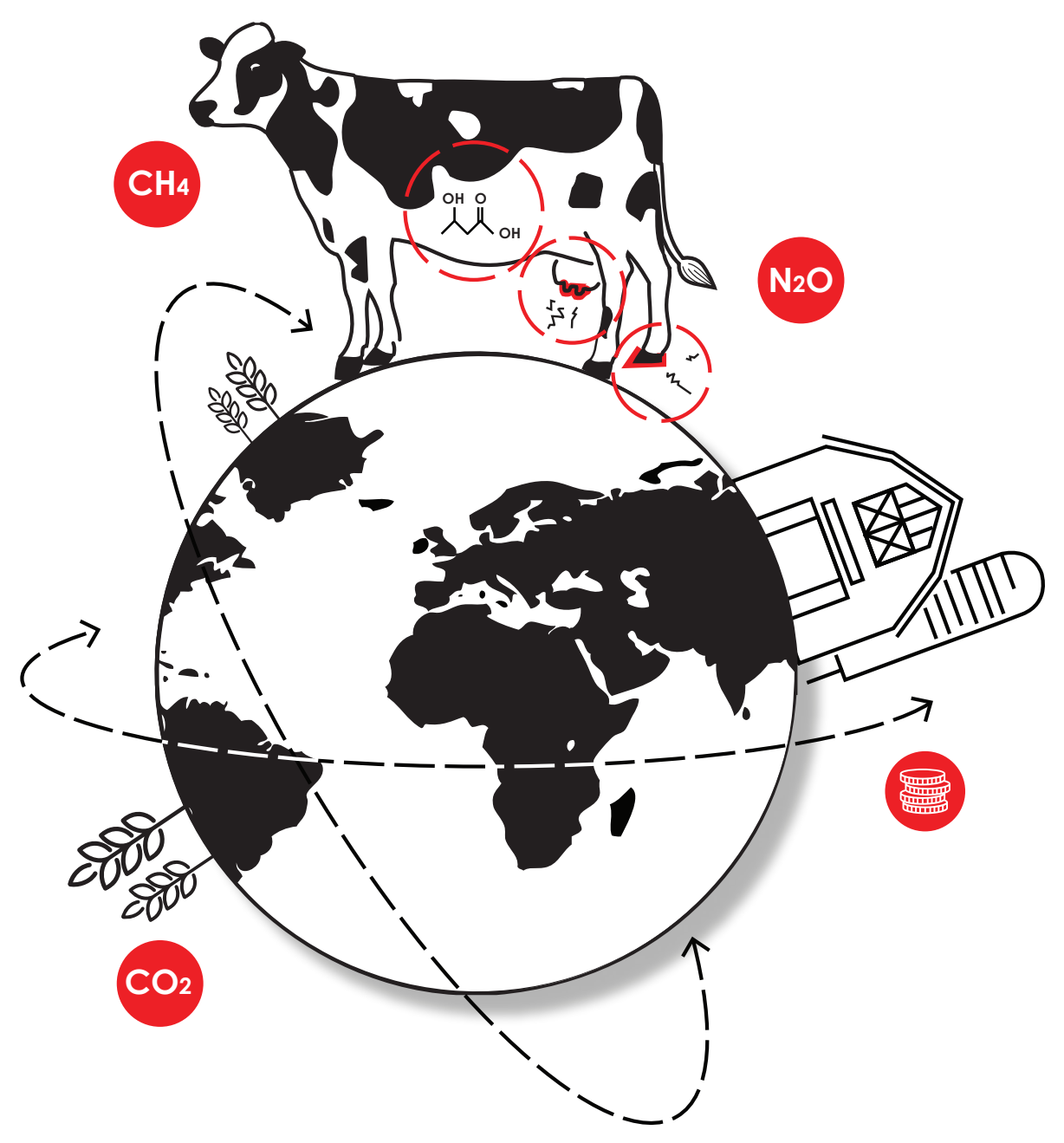

Pim Mostert 


\section{Propositions}

1. Increasing longevity is more important to reduce greenhouse gas emissions than to improve economic performance on dairy farms.

(this thesis)

2. Reducing diseases in dairy cows contributes to each pillar of sustainable development. (this thesis)

3. The certainty of life cycle assessment is uncertainty.

4. Maintaining current consumption levels in developed countries goes at the expense of quality of life in developing countries.

5. Instructions for authors that exceed their own allowed paper length are hilarious.

6. Future generations will lose the competence of non-verbal communication.

Propositions belonging to the thesis, entitled

'The impact of diseases in dairy cows on greenhouse gas emissions and economic performance.'

Pim Mostert

Wageningen, 25 June 2018 
The impact of diseases in dairy cows on greenhouse gas emissions and economic performance

Pim Mostert 


\section{Thesis committee}

\section{Promotor}

Prof. Dr I.J.M. de Boer

Professor of Animal Production Systems

Wageningen University \& Research

\section{Co-promotors}

Dr E.A.M. Bokkers

Associate professor, Animal Production Systems group

Wageningen University \& Research

Dr C.E. van Middelaar

Researcher, Animal Production Systems group

Wageningen University \& Research

\section{Other members}

Prof. Dr Y.H. Schukken, Wageningen University \& Research

Dr M.C.M. Mourits, Wageningen University \& Research

Dr A.G. Williams, Cranfield University, Bedford, United Kingdom

Dr L. Shalloo, Animal and Grassland Research and Innovation Centre (Teagasc), Fermoy, Ireland

This research was conducted under the auspices of the Graduate School of Wageningen Instititute of Animal Sciences (WIAS) 


\section{The impact of diseases in dairy cows on greenhouse gas emissions and economic performance}

Pim Mostert

\section{Thesis}

submitted in fulfilment of the requirements for the degree of doctor at Wageningen University by the authority of the Rector Magnificus,

Prof. Dr A.P.J. Mol,

in the presence of the

Thesis Committee appointed by the Academic Board

to be defended in public

on Monday 25 June 2018

at 1.30 p.m. in the Aula. 
Mostert, Pim

The impact of diseases in dairy cows on greenhouse gas emissions and economic performance, 152 pages.

PhD thesis, Wageningen University, Wageningen, the Netherlands (2018)

With references, with summaries in English and in Dutch

ISBN 978-94-6343-274-0

DOI https://doi.org/10.18174/445487 


\section{Abstract}

The world population is expected to grow to about 10 billion in 2050. To supply the future human population with food while sustaining a liveable planet, food should be produced sustainably. One of the most urgent environmental issues is climate change, induced by greenhouse gas (GHG) emissions. The dairy sector is a large contributor to GHG emissions. Important GHGs related to milk production are carbon dioxide $\left(\mathrm{CO}_{2}\right)$, methane $\left(\mathrm{CH}_{4}\right)$, and nitrous oxide $\left(\mathrm{N}_{2} \mathrm{O}\right)$, mainly emitted during feed production, enteric fermentation, and manure management. Diseases in dairy cows can reduce milk production, reproduction performance and longevity, and increase the amount of discarded milk. The objectives of this thesis were to estimate the impact of diseases (subclinical ketosis, clinical mastitis, and foot lesions) on GHG emissions, and to understand the relation between impact of diseases on GHG emissions and economic performance. First, a dynamic stochastic simulation model was developed to simulate the dynamics of the diseases and the associated production losses (reduced milk production, discarded milk, a prolonged calving interval, and removal (culling or dying on the farm)) per cow during one lactation. This model was combined with a life cycle assessment to quantify the impact of diseases on GHG emissions per ton fat-and-protein-corrected milk ( $\mathrm{kg} \mathrm{CO}{ }_{2}$ equivalents/t FPCM) from cradle to farm gate. Processes included were feed production, enteric fermentation, and manure management. The emissions of GHGs of cows with a disease increased on average by 21 (2.3\%) $\mathrm{kg} \mathrm{CO}_{2} \mathrm{e} / \mathrm{t}$ FPCM per case of subclinical ketosis, by 58 (6.2\%) $\mathrm{kg} \mathrm{CO}_{2} \mathrm{e} / \mathrm{t}$ FPCM per case of clinical mastitis, by 4 (0.4\%) $\mathrm{kg} \mathrm{CO}_{2} \mathrm{e} /$ $\mathrm{t}$ FPCM per case of digital dermatitis, by 39 (4.3\%) $\mathrm{kg} \mathrm{CO}_{2} \mathrm{e} / \mathrm{t}$ FPCM per case of white line disease, and by 33 (3.6\%) $\mathrm{kg} \mathrm{CO}_{2} \mathrm{e} / \mathrm{t}$ FPCM per case of sole ulcer. An economic analyses was performed to estimate the costs of subclinical ketosis and related diseases. The total costs of subclinical ketosis were $€ 130$ per case per year. Comparing the impact of production contributors from a GHG emissions and economic perspective showed that a reduction in milk production had the highest impact on the economic performance, whereas removal and discarded milk had the highest impact on increase in GHG emissions. Prevalence, pathogen type, farm management (e.g. culling, feed, and manure), and prices (e.g. milk and feed) will affect the impact of production contributors on GHG emissions and economic performance. Therefore, specific farm analyses are needed to estimate the impact of diseases for a specific dairy farm. Diseases in dairy cows increase GHG emissions by approximately 0.4 Mton per year, which equals 15\% of the Dutch governmental goal of GHG emission reductions in agriculture in 2030. Reducing diseases can decrease GHG emissions, can increase the income of the farmer, and can improve animal welfare. Therefore, reducing diseases can contribute to sustainable development of the dairy sector. 



\section{Contents}

Chapter 1 General introduction 1

Chapter 2 The impact of subclinical ketosis in dairy cows on

greenhouse gas emissions of milk production

15

Chapter 3 The impact of clinical mastitis in dairy cows on

greenhouse gas emissions of milk production

Chapter 4 The impact of foot lesions in dairy cows on

greenhouse gas emissions of milk production

67

Chapter 5 Estimating the economic impact of subclinical ketosis in

dairy cattle using a dynamic stochastic simulation model

87

Chapter 6 General discussion

111

Summary

133

Samenvatting

137

Dankwoord

141

About the author

143

Publications

145

Education certificate

147

Colophon 



\section{Chapter 1}

\section{General introduction}

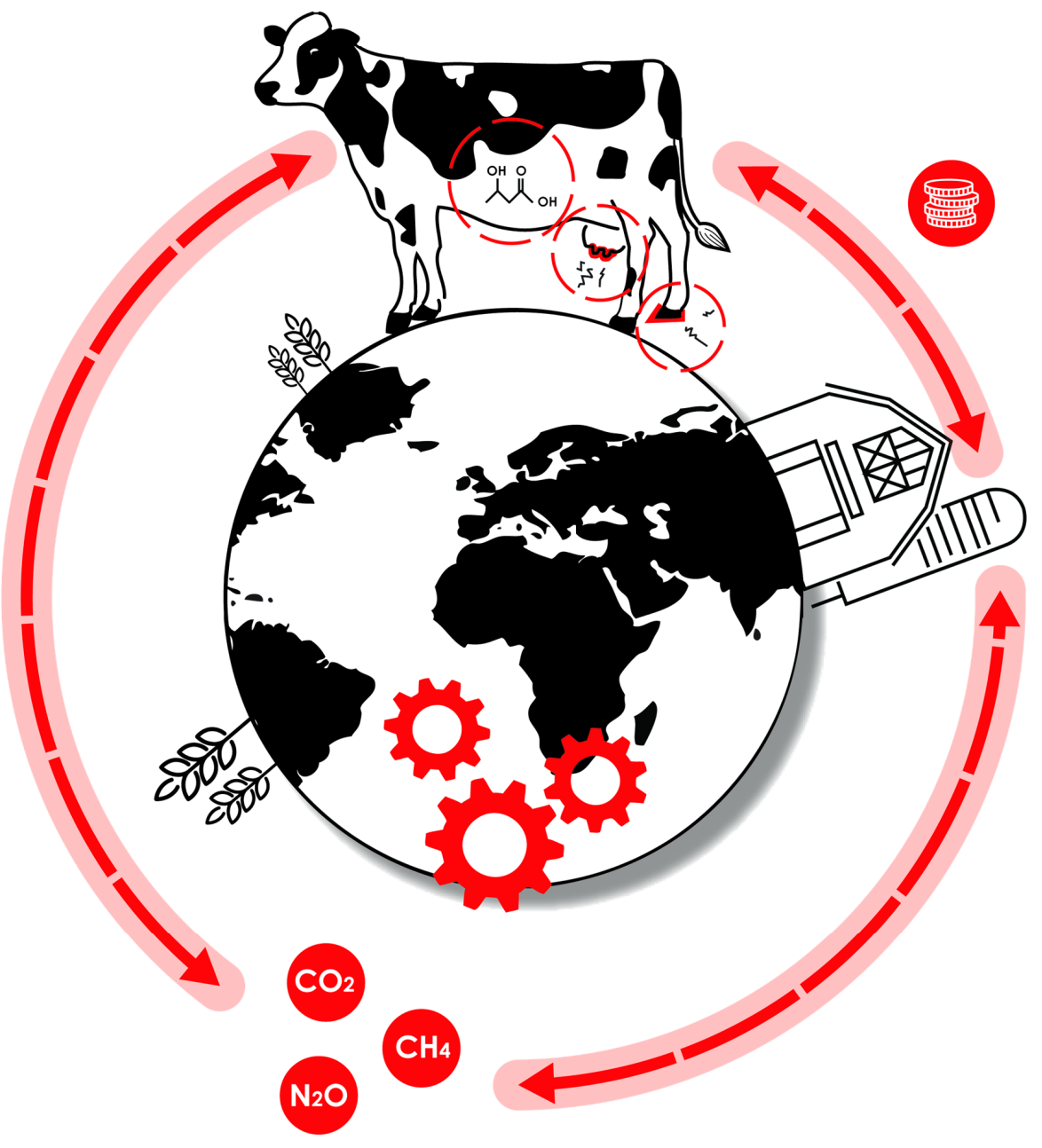




\section{Background}

The world population is expected to grow to about 10 billion in 2050. Feeding this growing population will be an enormous challenge. Natural resources, such as land and water, will become more scarce (Gerber et al., 2013). Moreover, food production has an important contribution to environmental issues, such as climate change. To supply the future human population with food while sustaining a liveable planet, food should be produced sustainably.

\section{Sustainability}

Sustainable development is defined as 'development that meets the needs of the present without compromising the ability of future generations to meet their own needs' (Brundtland, 1987). The definition of Brundtland already recognized the three pillars of sustainability that are currently widely acknowledged: social, economic, and environmental sustainability. Social sustainability represents various issues. In agricultural field, social sustainability is associated with issues such as food safety, working conditions, and animal welfare (van Calker et al., 2005). Economic sustainability is the difference between the value of goods and services produced, and the costs of resources used during production, and is mostly associated with profitability (Van Calker et al., 2005). Environmental sustainability implies living within the carrying capacity of the Earth system, and includes issues of climate change, acidification, depletion of fossil fuels (De Boer, 2012).

Of these three pillars, environmental sustainability is increasingly seen as the most important pillar, because without a life support system, societies and economics cannot thrive (Fischer et al., 2007). Related to that are the planetary boundaries of the Earth system. Planetary boundaries show the space for humanity to operate without affecting the stability of the Earth. One of the most urgent environmental issues that exceeds the planetary boundary, is climate change, induced by greenhouse gas (GHG) emissions (Steffen et al., 2015). Observed changes in climate are an increase in intensity and frequency of heat waves, number of heavy rainfalls in many regions, and increased drought in some regions of the world (Steffen et al., 2015). These changes can have a negative impact on ecosystems, liveability of certain regions, and human health, and therefore are a severe risk for humanity.

The current livestock sector is responsible for about $14.5 \%$ of the global human- induced emissions of GHGs (Gerber et al., 2013). Dairy cattle, producing milk, meat and non-edible products like manure, are responsible for about $30 \%$ of total livestock sector GHG emissions (Gerber et al., 
2013). Important GHGs related to milk production are carbon dioxide $\left(\mathrm{CO}_{2}\right)$, methane $\left(\mathrm{CH}_{4}\right)$, and nitrous oxide $\left(\mathrm{N}_{2} \mathrm{O}\right)$. Emission of $\mathrm{CO}_{2}$ results, for example, from fossil fuels used during feed production or transport of products. Emission of $\mathrm{CH}_{4}$ results, for example, from enteric fermentation and manure management practices. Emission of $\mathrm{N}_{2} \mathrm{O}$ results, for example, from manure storage and nitrogen application during crop production. Although dairy cows emit a significant amount of GHGs, milk also provides highly bioavailable protein and important micronutrients, such as vitamin B-12 and calcium, for humans (Murphy and Allen, 2003). Moreover, dairy cows can convert human inedible products, such as grass and crop residues, into human food, such as milk and meat.

The productivity of dairy cows in European countries has increased considerably the last decades. In 2014, the global production of fresh milk from dairy cows was approximately 652 million tonnes (FAOSTAT, 2017a), of which 159 million tonnes were produced in the European Union. Approximately $62 \%$ of the milk production in the European Union is produced by five countries, namely France, Germany, Poland, the Netherlands, and United Kingdom. In these countries, annual milk production per dairy cow increased, and consequently the same amount of milk could be produced with fewer dairy cows (Figure 1).

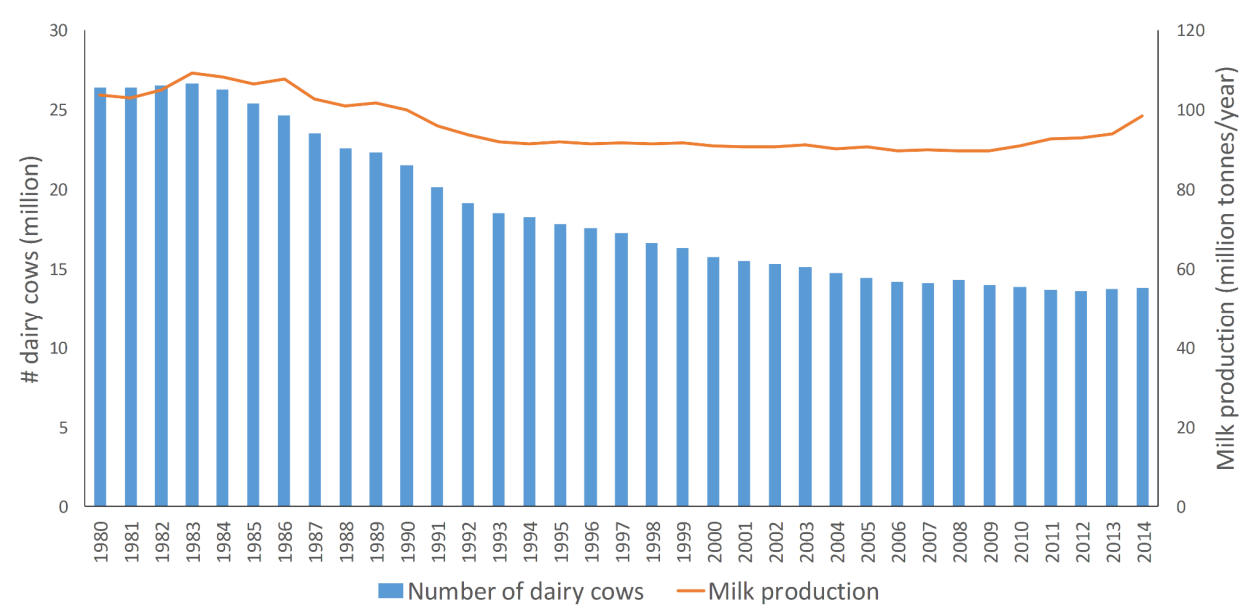

Figure 1. Total number of cows and milk production of five countries (France, Germany, Poland, the Netherlands, and United Kingdom) in the European Union with the highest milk production (FAOSTAT, 2017a). 
If current trends continue, the future global milk consumption in 2050 is expected to increase by 70\% compared with 2013 (FAOSTAT, 2017b). Given this expected increase in demand for milk, the limited amount of resources, and GHG emissions of dairy production, production of milk with a lower environmentally impact is urgent. In this context, an efficient milk production, meaning producing milk with the lowest environmental impact possible, is a way to reduce the environmental impact of milk production. This can be achieved by e.g. feeding strategies, or by reducing milk production losses. Feeding strategies that could reduce GHG emissions are, for example, supplementation of an extruded linseed product or of dietary nitrate source, or using beet tails, a co-product, in diets of dairy cattle (Van Middelaar et al., 2014; Van Zanten et al., 2014). Milk production losses are mainly caused by diseases. Milk production losses result in reduced milk production and fertility of cows, and discarded milk when animals are treated with antibiotics. Many diseases can occur during the life of a dairy cow, and health issues are the main reason for culling of cows (Hadley et al., 2006). Diseases in dairy cows occur in developed and developing countries. Factors such as housing, feeding, and management of the dairy cow often affect the risk of diseases.

Diseases in dairy cows increase e.g. the amount of labour for farmers, treatment costs, reduce feed efficiency ( $\mathrm{kg}$ feed intake/kg milk), and therefore reduce the income of the farmer. Reduced feed efficiency of dairy cows also affects GHG emissions related to feed production (production of inputs, e.g. fertilizers, cultivation, and processing stages), enteric fermentation (i.e. digestion of the feed by the cow), and manure management per unit of milk produced. Furthermore, an increased removal rate, results in additional breeding of replacement heifers, which increases the costs and GHG emissions related to non-productive animals.

Feeding strategies can reduce GHG emissions, but as a trade-off can reduce the income of farmers (Van Middelaar et al., 2014). Reducing diseases can reduce GHG emissions, and several studies showed that this also can increase the income of farmers (Bruijnis et al., 2012; Liang et al., 2017; Van Soest et al., 2016). Moreover, reducing diseases will improve the welfare of dairy cows and therefore have a positive impact on all three sustainability pillars.

\section{Diseases of dairy cows}

The prevalence of diseases varies among countries, farms, parity of the cow, and stage of lactation. Table 1 shows the main diseases of dairy cows and the average prevalence found in literature during a lactation on farms in North America and Europe. Variation between studies is high and can be even higher between farms within one country. 
Table 1. Average prevalence (minimum-mean-maximum) found in literature of most frequent diseases in dairy cows during an average lactation on farms in North America and Europe.

\begin{tabular}{llll}
\hline Disease & Minimum & Mean & Maximum \\
\hline Lameness & 2 & 30 & 70 \\
Clinical mastitis $^{1}$ & 2 & 27 & 82 \\
Subclinical ketosis & 11 & 25 & 49 \\
Retained placenta & 7 & 10 & 16 \\
Metritis & 3 & 10 & 36 \\
Displaced abomasum & 2 & 4 & 7 \\
\hline
\end{tabular}

${ }^{1}$ Clinical mastitis is expressed in incidence

(Berge and Vertenten, (2014); Cameron et al. (1998); Chapinal et al. (2011); Green et al. (2002); McArt et al. (2013); Quiroz-Rocha et al. (2009); Raboisson et al. (2015); Suthar et al. (2013); Van Soest et al. (2016); Walsh et al. (2007))

Lameness can reoccur during the whole lactation and across lactations. Lameness reduces milk production by 270 to $574 \mathrm{~kg}$ per cow per lactation, reduces several aspects of reproduction performance (e.g. calving to conception interval, days open, calving interval), and increases the risk of culling (Huxley, 2013). Costs for lameness are estimated at $\$ 75$ per cow per year on herd level (Bruijnis et al., 2010). About 90\% of lameness cases are associated with foot lesions (Murray et al., 1996; Somers and O'Grady, 2015). Foot lesions can be classified in infectious and noninfectious lesions. Examples of infectious lesions are interdigital phlegmon, interdigital dermatitis and heel horn erosion, and digital dermatitis. Examples of non-infectious lesions are sole hemorrhage, white line disease, sole ulcer, and interdigital hyperplasia. Non-infectious lesions are caused by physical or metabolic disturbance (Bruijnis et al., 2010).

Clinical mastitis is an intramammary infection that can reoccur in the same lactation and across lactations due to several pathogens. Pathogens can be classified as gram-positive bacteria (e.g. Streptococcus spp), gram-negative bacteria (e.g. E.coli), and other organisms (Schukken et al., 2009). Clinical mastitis reduces the milk production of an affected cow by on average $5 \%$ per year, increases the risk of removal by 1.5-5.0 and reduces the probability of successful conception (Hertl et al., 2014; Seegers et al., 2003). Costs associated with mastitis are estimated between on average $€ 61-€ 97$ per cow per year on herd level (Hogeveen et al., 2011), whereas costs per case are estimated at \$134 for gram-positive, \$211 for gram-negative, and \$95 for other organisms (Cha et al., 2011).

Subclinical ketosis in dairy cows is a metabolic disorder that occurs in the period around calving. In this period, the energy requirement of the cow can exceed her energy intake, resulting in a negative energy balance (Grummer, 1995). A negative energy balance results in an increase of non- 
6 | Chapter 1

esterified fatty acids and beta-hydroxybutyrate levels in the blood. A cow is considered to have subclinical ketosis when the beta-hydroxybutyrate level is higher than 1.2-1.4 mmol/l blood, but shows no clinical signs of ketosis (Raboisson et al., 2014). Subclinical ketosis increases the risk of clinical ketosis and other diseases such as displaced abomasum, metritis, lameness, mastitis (Berge and Vertenten, 2014). Subclinical ketosis reduces milk production by $340 \mathrm{~kg}$ per lactation, reduces several aspects of reproduction and can increase the risk of removal (Raboisson et al., 2014). Costs of subclinical ketosis have been estimated at $€_{257}$ (Raboisson et al., 2015) and \$289 (McArt et al., 2015) per case of subclinical ketosis.

This thesis focuses on foot lesions, clinical mastitis, and subclinical ketosis.

\section{Knowledge gaps}

Diseases have an economic impact and can increase GHG emissions per unit output. Although the economic impact of diseases in dairy cows has been well investigated, little attention has been given to the impact of diseases in dairy cows on GHG emissions. Several studies estimated the impact of other strategies to reduce GHG emissions of dairy cows. A review about feeding strategies showed that enteric $\mathrm{CH}_{4}$ emissions could be reduced by e.g. improving forage quality, by increasing the amount of concentrates over roughage, or by including dietary lipids (Hristov et al., 2013). Garnsworthy (2004) showed that improving fertility of dairy cows can reduce $\mathrm{CH}_{4}$ herd emissions by $16 \%$, whereas Bannink et al. (2011) showed that increasing the daily milk yield per cow from 17.2 to $22.9 \mathrm{~kg}$ decreased enteric $\mathrm{CH}_{4}$ emissions per unit of milk by $13 \%$. A different strategy to reduce GHG emissions, however, might also affect other GHGs and processes along the production chain. A change in diet, for example, might reduce enteric $\mathrm{CH}_{4}$ on the farm but will also affect other GHGs $\left(\mathrm{CO}_{2}, \mathrm{~N}_{2} \mathrm{O}\right)$ and processes (emissions from manure and feed production) along the chain (Van Middelaar et al., 2013). Therefore an integrated approach is needed that includes all processes and emissions that are affected to analyse a strategy. Life cycle assessment is a common method to assess GHG emissions, and includes all relevant chain processes during the production of milk and meat. Life cycle assessment has been used to estimate the impact of feeding strategies (Van Middelaar et al., 2014), improving fertility (Bell et al., 2011), increasing longevity (Bell et al., 2011) or milk production of dairy cows (Gerber et al., 2011).

Only a few studies estimated the impact of diseases on GHG emissions. Williams et al. (2015) estimated the impact of 10 endemic cattle diseases, Özkan Gülzari et al. (2018) the impact of subclinical mastitis, Hospido and Sonesson (2005) the impact of mastitis, and Chen et al. (2016) the impact of lameness on GHG emissions. Although the four studies gave an indication of the 
impact of some diseases on GHG emissions, they did not analyse the underlying factors. Also, they did not include different and dynamics of pathogens of diseases, different parity of cows, variation in production losses and GHG emissions, and did not analyse different production parameters (e.g. culling, reproduction) per type of diseases. Including these aspects can give new and better insights into the impact of diseases on GHG emissions.

Many studies already estimated the costs of mastitis and foot lesions. Only two studies, however, estimated the economic impact of subclinical ketosis (McArt et al., 2015; Raboisson et al., 2015). These studies used two different types of models to estimate the production losses and included different relations of subclinical ketosis and other diseases. Using a deterministic model, McArt et al. (2015) estimated the economic impact at $\$ 289$ per case of subclinical ketosis. They included only the relation of subclinical ketosis with metritis, displaced abomasum, and ovarian dysfunction and therefore might have underestimated the total costs of subclinical ketosis. Raboisson et al. (2015) developed a stochastic simulation model and included more diseases related to subclinical ketosis, resulting in an estimated economic impact of $€ 257$ per case of subclinical ketosis. This study, however, did not distinguish between removal risks of cows with only subclinical ketosis and of cows with subclinical ketosis and a related disease, which might have led to an over- or underestimation of costs. Furthermore, McArt et al. (2015) and Raboisson et al. (2015) only distinguished primiparous and multiparous cows, while prevalence of subclinical ketosis and related diseases, milk production, calving interval, energy requirement, and removal risk can differ between multiparous cows (Bar et al., 2008; Berge and Vertenten, 2014; CRV, 2014).

Using a dynamic stochastic simulation model and distinguishing between the removal risks of cows with only subclinical ketosis and of cows with subclinical ketosis and a related disease, and including several parities, can provide new insight into the costs of subclinical ketosis.

Moreover, having an economic and environmental analyses on the same production losses makes it possible to compare the output and to show synergies and trade-offs between impact of diseases on the economic and environmental sustainability.

\section{Aim of thesis}

The objectives of this thesis are:

- $\quad$ To estimate the impact of diseases in dairy cows on greenhouse gas emissions;

- $\quad$ To understand the relation between impact of diseases on greenhouse gas emissions and economic performance. 
8 | Chapter 1

Most data of disease prevalence, production losses of diseases, and emissions that occur during the production of milk, are available from western countries, and therefore, in this thesis analyses are done for conventional dairy farms in western countries.

\section{Research approach}

To assess the impact of diseases on GHG emissions, first a dynamic stochastic simulation model is developed to estimate production losses associated with diseases. Dynamic stochastic simulation models are commonly used to estimate these production losses, especially in studies that estimated the impact of diseases on the income of the farmer (Bruijnis et al., 2010, Huijps and Hogeveen, 2007). This type of model simulates diseases and production of a cow over time and shows the variation in production performances (Dijkhuizen et al., 1997).

Second, a life cycle assessment model is developed to estimate GHG emissions. Emissions from processes that occur on the farm need to be included, such as maize and grass production, and manure management, but also processes that occur off the farm, such as production of concentrates and related input (e.g. fertilizer, energy) (Figure 2).

Finally, the dynamic stochastic simulation model is combined with the life cycle assessment model to estimate the impact of the production losses of diseases on GHG emissions. Subsequently, the developed dynamic stochastic simulation model was used to estimate the economic impact of subclinical ketosis.

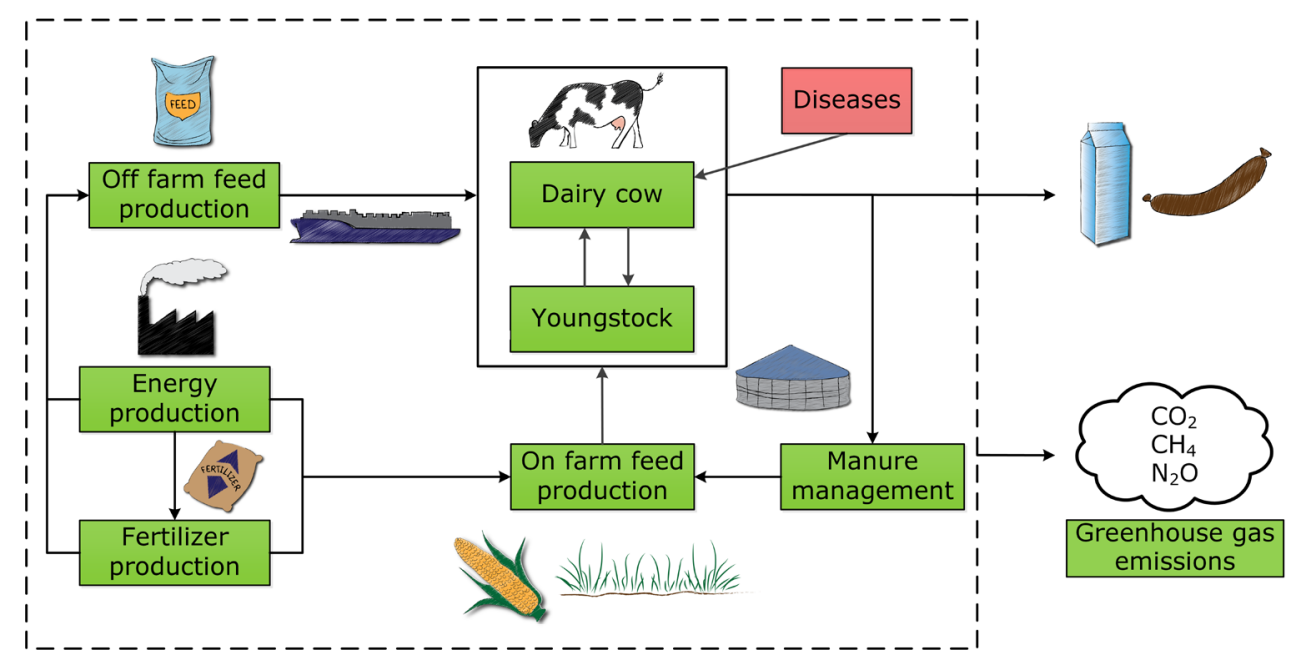

Figure 2. Included processes along the milk production chain to estimate the impact of diseases on greenhouse gas emissions $\left(\mathrm{CO}_{2}\right.$ (carbon dioxide), $\mathrm{CH}_{4}$ (methane), $\mathrm{N}_{2} \mathrm{O}$ (nitrous oxide)). 


\section{Outline of thesis}

The structure and chapters of the thesis are shown in Figure 3. Chapter 2 describes the methodology to estimate the impact of diseases on GHG emissions and estimates the impact of subclinical ketosis on GHG emissions.

Chapter 3 applies the method developed in chapter 2 to estimate the impact of clinical mastitis on GHG emissions. Chapter 4 applies the method developed in chapter 2 to estimate the impact of foot lesions on GHG emissions. Chapter 5 estimates the economic impact of subclinical ketosis. In chapter 6 the impact of reducing diseases in dairy cows on GHG emissions is estimated and the relation between impact of diseases on the GHG emissions and economic performance is discussed. Moreover, the developed method to estimate GHG emissions is discussed, and implications of reducing GHG emissions, and conclusions are given.

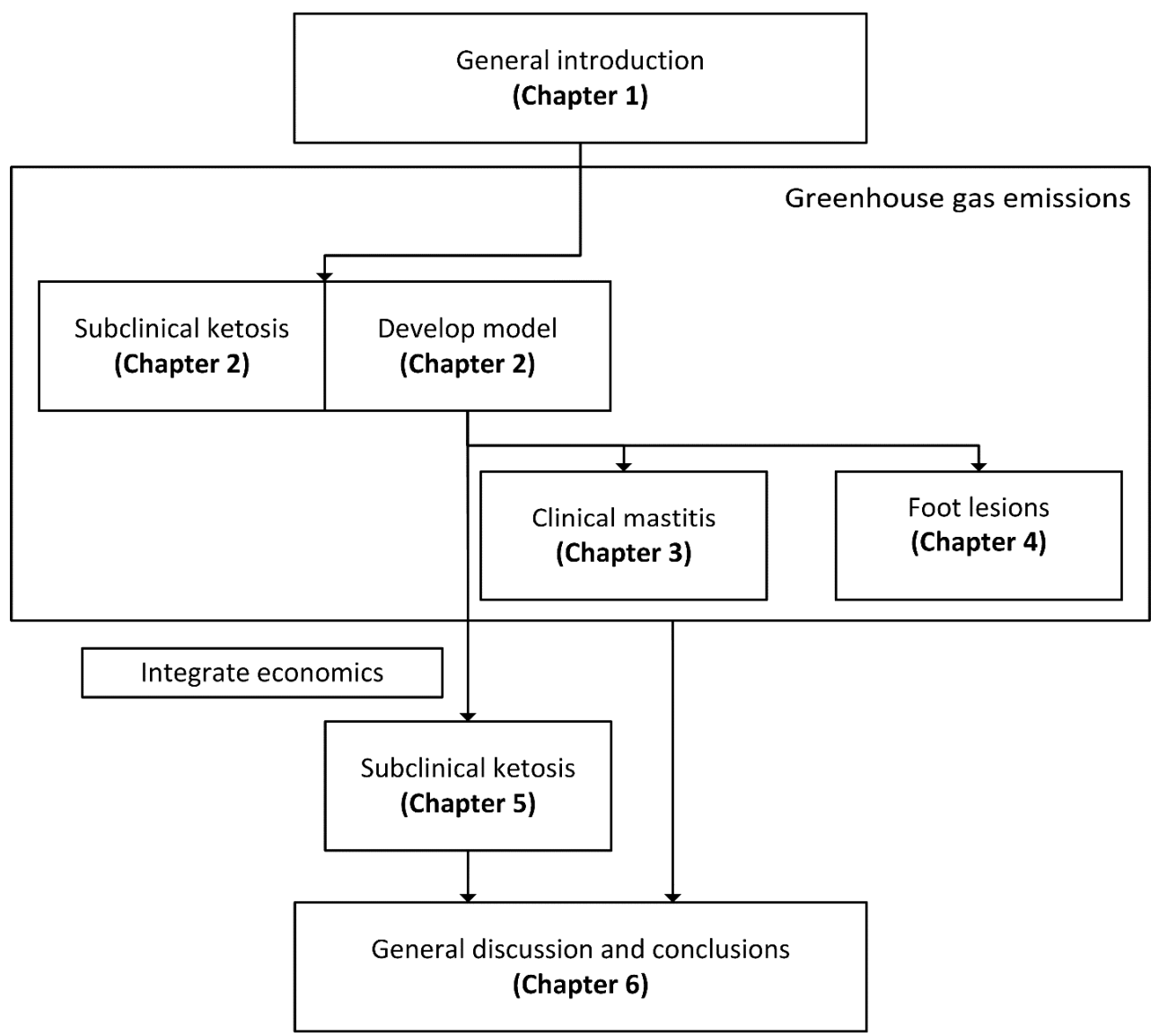

Figure 3. Overview of the chapters and structure of the thesis. 


\section{References}

Bannink, A., van Schijndel, M.W., Dijkstra, J., 2011. A model of enteric fermentation in dairy cows to estimate methane emission for the Dutch National Inventory Report using the IPCC Tier 3 approach. Anim. Feed Sci. Technol. 166-167, 603-618.

Bar, D., Gröhn, Y.T., Bennett, G., González, R.N., Hertl, J.A., Schulte, H.F., Tauer, L.W., Welcome, F.L., Schukken, Y.H., 2008. Effects of repeated episodes of generic clinical mastitis on mortality and culling in dairy cows. J. Dairy Sci. 91, 2196-2204.

Bell, M.J., Wall, E., Russell, G., Simm, G., Stott, A.W., 2011. The effect of improving cow productivity, fertility, and longevity on the global warming potential of dairy systems. J. Dairy Sci. 94, 3662-3678.

Berge, A.C., Vertenten, G., 2014. A field study to determine the prevalence, dairy herd management systems, and fresh cow clinical conditions associated with ketosis in western European dairy herds. J. Dairy Sci. 97, 2145-2154.

Bruijnis, M.R.N., Beerda, B., Hogeveen, H., Stassen, E.N., 2012. Assessing the welfare impact of foot disorders in dairy cattle by a modeling approach. Animal 6, 962-970.

Bruijnis, M.R.N., Hogeveen, H., Stassen, E.N., 2010. Assessing economic consequences of foot disorders in dairy cattle using a dynamic stochastic simulation model. J. Dairy Sci. 93, 2419-2432.

Brundtland. 1987. World Commission on Environment and Development: Our common future. University press, Oxford.

Cameron, R.E.B., Dyk, P.B., Herdt, T.H., Kaneene, J.B., Miller, R., Bucholtz, H.F., Liesman, J.S., Vandehaar, M.J., Emery, R.S., 1998. Dry Cow Diet, Management, and Energy Balance as Risk Factors for Displaced Abomasum in High Producing Dairy Herds. J. Dairy Sci. 81, 132-139.

Cha, E., Bar, D., Hertl, J.A., Tauer, L.W., Bennett, G., González, R.N., Schukken, Y.H., Welcome, F.L., Gröhn, Y.T., 2011. The cost and management of different types of clinical mastitis in dairy cows estimated by dynamic programming. J. Dairy Sci. 94, 4476-4487.

Chapinal, N., Carson, M., Duffield, T.F., Capel, M., Godden, S., Overton, M., Santos, J.E.P., LeBlanc, S.J., 2011. The association of serum metabolites with clinical disease during the transition period. J. Dairy Sci. 94, 4897-4903.

Chen, W., White, E., Holden, N.M., 2016. The effect of lameness on the environmental performance of milk production by rotational grazing. J. Environ. Manage. 172, 143-150.

CRV 2014. Jaarstatistieken 2014 voor Nederland (Annual statistics 2014). CRV, Arnhem, the Netherlands.

De Boer, I. J. M. 2012. Innovation born of integration: moving towards sustainable production of animal-source food. Inaugural lecture, Wageningen University, Wageningen.

Dijkhuizen, A.A., Jalvingh, A.W., Huirne, R.B.M., 1997. Critical steps in systems simulation, In: A.A. Dijkhuizen and R.S. Morris (Eds) Animal health economics: principles and 
applications, Post graduate foundation in Veterinary Science, University of Sydney, Sydney South, Australia (1997) 59-68.

FAOSTAT. 2017a. Production, milk whole, accessed 13 November. http://www.fao.org/faostat/en/\#data.

FAOSTAT. 2017b. Alexandratos and Bruinsma, 2012. World Agriculture Towards 2030/2050. The 2012 Revision. ESA Working Paper No. 10-03. June 2012 (Data in Table 4.18. Page. 131). Updated data from 2005 to 2013, based on latest data of FAOSTAT, 2017. Food supply Livestock and Fish Primary Equivalent, accessed 1 December. http://www.fao.org/faostat/en/\#data.

Fischer, J., Manning, A.D., Steffen, W., Rose, D.B., Daniell, K., Felton, A., Garnett, S., Gilna, B., Heinsohn, R., Lindenmayer, D.B., MacDonald, B., Mills, F., Newell, B., Reid, J., Robin, L., Sherren, K., Wade, A., 2007. Mind the sustainability gap. Trends Ecol. Evol. 22, 621-624.

Garnsworthy, P.C., 2004. The environmental impact of fertility in dairy cows: A modelling approach to predict methane and ammonia emissions. Anim. Feed Sci. Technol. 112, 211223.

Gerber, P., Vellinga, T., Opio, C., Steinfeld, H., 2011. Productivity gains and greenhouse gas emissions intensity in dairy systems. Livest. Sci. 139, 100-108.

Gerber, P.J., Steinfeld, H., Henderson, B., Mottet, A., Opio, C., Dijkman, J., Falcucci, A., Tempio, G., 2013. Tackling climate change through livestock - A global assessment of emissions and mitigation opportunities. Food and Agriculture Organization of the United Nations (FAO), Rome.

Green, L.E., Hedges, V.J., Schukken, Y.H., Blowey, R.W., Packington, A.J., 2002. The Impact of Clinical Lameness on the Milk Yield of Dairy Cows. J. Dairy Sci. 85, 2250-2256.

Grummer, R.R., 1995. Impact of changes in organic nutrient metabolism on feeding the transition dairy cow. J. Anim. Sci. 73, 2820-2833.

Hadley, G.L., Wolf, C.A., Harsh, S.B., 2006. Dairy Cattle Culling Patterns, Explanations, and Implications. J. Dairy Sci. 89, 2286-2296.

Hertl, J.A., Schukken, Y.H., Welcome, F.L., Tauer, L.W., Gröhn, Y.T., 2014. Effects of pathogenspecific clinical mastitis on probability of conception in Holstein dairy cows. J. Dairy Sci. 97, 6942-6954.

Hogeveen, H., Huijps, K., Lam, T., 2011. Economic aspects of mastitis: New developments. N. Z. Vet. J. 59, 16-23.

Hospido, A., Sonesson, U., 2005. The environmental impact of mastitis: a case study of dairy herds. Sci. Total Environ. 343, 71-82.

Hristov, A.N., Oh, J., Firkins, J.L., Dijkstra, J., Kebreab, E., Waghorn, G., Makkar, H.P.S., Adesogan, A.T., Yang, W., Lee, C., Gerber, P.J., Henderson, B., Tricarico, J.M., 2013. SPECIAL TOPICS - Mitigation of methane and nitrous oxide emissions from animal operations: I. A review of enteric methane mitigation options. J. Anim. Sci. 91, 5045-5069. 
Huijps, K., Hogeveen, H., 2007. Stochastic modeling to determine the economic effects of blanket, selective, and no dry cow therapy. J. Dairy Sci. 90, 1225-1234.

Huxley, J.N., 2013. Impact of lameness and claw lesions in cows on health and production. Livest. Sci. 156, 64-70.

Liang, D., Arnold, L.M., Stowe, C.J., Harmon, R.J., Bewley, J.M., 2017. Estimating US dairy clinical disease costs with a stochastic simulation model. J. Dairy Sci. 100, 1472-1486.

McArt, J.A.A., Nydam, D.V., Oetzel, G.R., 2013. Dry period and parturient predictors of early lactation hyperketonemia in dairy cattle. J. Dairy Sci. 96, 198-209.

McArt, J.A.A., Nydam, D.V., Overton, M.W., 2015. Hyperketonemia in early lactation dairy cattle: A deterministic estimate of component and total cost per case. J. Dairy Sci. 98, 2043-2054.

Murphy, S.P., Allen, L.H., 2003. Nutritional Importance of Animal Source Foods. J. Nutr. 133, 3932S-3935S.

Murray, R.D., Downham, D.Y., Clarkson, M.J., Faull, W.B., Hughes, J.W., Manson, F.J., Merritt, J.B., Russell, W.B., Sutherst, J.E., Ward, W.R., 1996. Epidemiology of lameness in dairy cattle: Description and analysis of foot lesions. Vet. Rec. 138, 586-591.

Özkan Gülzari, ş., Vosough Ahmadi, B., Stott, A.W., 2018. Impact of subclinical mastitis on greenhouse gas emissions intensity and profitability of dairy cows in Norway. Prev. Vet. Med. 150, 19-29.

Quiroz-Rocha, G.F., LeBlanc, S., Duffield, T., Wood, D., Leslie, K.E., Jacobs, R.M., 2009. Evaluation of prepartum serum cholesterol and fatty acids concentrations as predictors of postpartum retention of the placenta in dairy cows. J. Am. Vet. Med. Assoc. 234, 790-793.

Raboisson, D., Mounié, M., Khenifar, E., Maigné, E., 2015. The economic impact of subclinical ketosis at the farm level: Tackling the challenge of over-estimation due to multiple interactions. Prev. Vet. Med. 122, 417-425.

Raboisson, D., Mounié, M., Maigné, E., 2014. Diseases, reproductive performance, and changes in milk production associated with subclinical ketosis in dairy cows: A meta-analysis and review. J. Dairy Sci. 97, 7547-7563.

Schukken, Y.H., Hertl, J., Bar, D., Bennett, G.J., González, R.N., Rauch, B.J., Santisteban, C., Schulte, H.F., Tauer, L., Welcome, F.L., Gröhn, Y.T., 2009. Effects of repeated grampositive and gram-negative clinical mastitis episodes on milk yield loss in Holstein dairy cows. J. Dairy Sci. 92, 3091-3105.

Seegers, H., Fourichon, C., Beaudeau, F., 2003. Production effects related to mastitis and mastitis economics in dairy cattle herds. Vet. Res. 34, 475-491.

Somers, J., O'Grady, L., 2015. Foot lesions in lame cows on 10 dairy farms in Ireland. Ir. Vet. J. 68. Steffen, W., Richardson, K., Rockström, J., Cornell, S.E., Fetzer, I., Bennett, E.M., Biggs, R., Carpenter, S.R., de Vries, W., de Wit, C.A., Folke, C., Gerten, D., Heinke, J., Mace, G.M., Persson, L.M., Ramanathan, V., Reyers, B., Sörlin, S., 2015. Planetary boundaries: Guiding human development on a changing planet. Science 347. 
Suthar, V.S., Canelas-Raposo, J., Deniz, A., Heuwieser, W., 2013. Prevalence of subclinical ketosis and relationships with postpartum diseases in European dairy cows. J. Dairy Sci. 96, 29252938.

Van Calker, K., Berentsen, P.M., Giesen, G.J., Huirne, R.M., 2005. Identifying and ranking attributes that determine sustainability in Dutch dairy farming. Agric. Human Values 22, 53-63.

Van Middelaar, C.E., Berentsen, P.B.M., Dijkstra, J., De Boer, I.J.M., 2013. Evaluation of a feeding strategy to reduce greenhouse gas emissions from dairy farming: The level of analysis matters. Agric. Sys. 121, 9-22.

Van Middelaar, C.E., Dijkstra, J., Berentsen, P.B.M., De Boer, I.J.M., 2014. Cost-effectiveness of feeding strategies to reduce greenhouse gas emissions from dairy farming. J. Dairy Sci. 97, 2427-2439.

Van Soest, F.J.S., Santman-Berends, I.M.G.A., Lam, T.J.G.M., Hogeveen, H., 2016. Failure and preventive costs of mastitis on Dutch dairy farms. J. Dairy Sci. 99, 8365-8374.

Van Zanten, H.H.E., Mollenhorst, H., De Vries, J.W., Van Middelaar, C.E., Van Kernebeek, H.R.J., De Boer, I.J.M., 2014. Assessing environmental consequences of using co-products in animal feed. Int. J. Life Cycle Assess. 19, 79-88.

Walsh, R.B., Walton, J.S., Kelton, D.F., LeBlanc, S.J., Leslie, K.E., Duffield, T.F., 2007. The effect of subclinical ketosis in early lactation on reproductive performance of postpartum dairy cows. J. Dairy Sci. 90, 2788-2796.

Williams, A., Chatterton, J., Hateley, G., Curwen, A., Elliott, J., 2015. A systems-life cycle assessment approach to modelling the impact of improvements in cattle health on greenhouse gas emissions. Adv. Anim. Biosci. 6, 29-31. 



\section{Chapter 2}

\section{The impact of subclinical ketosis in dairy cows on greenhouse gas emissions of milk production}

P.F. Mostert, C.E. van Middelaar, E.A.M. Bokkers, and I.J.M. de Boer.

Animal Production Systems group, Wageningen University \& Research, PO Box 338, 6700 AH

Wageningen, the Netherlands

Journal of Cleaner Production 171 (2018) 773-782

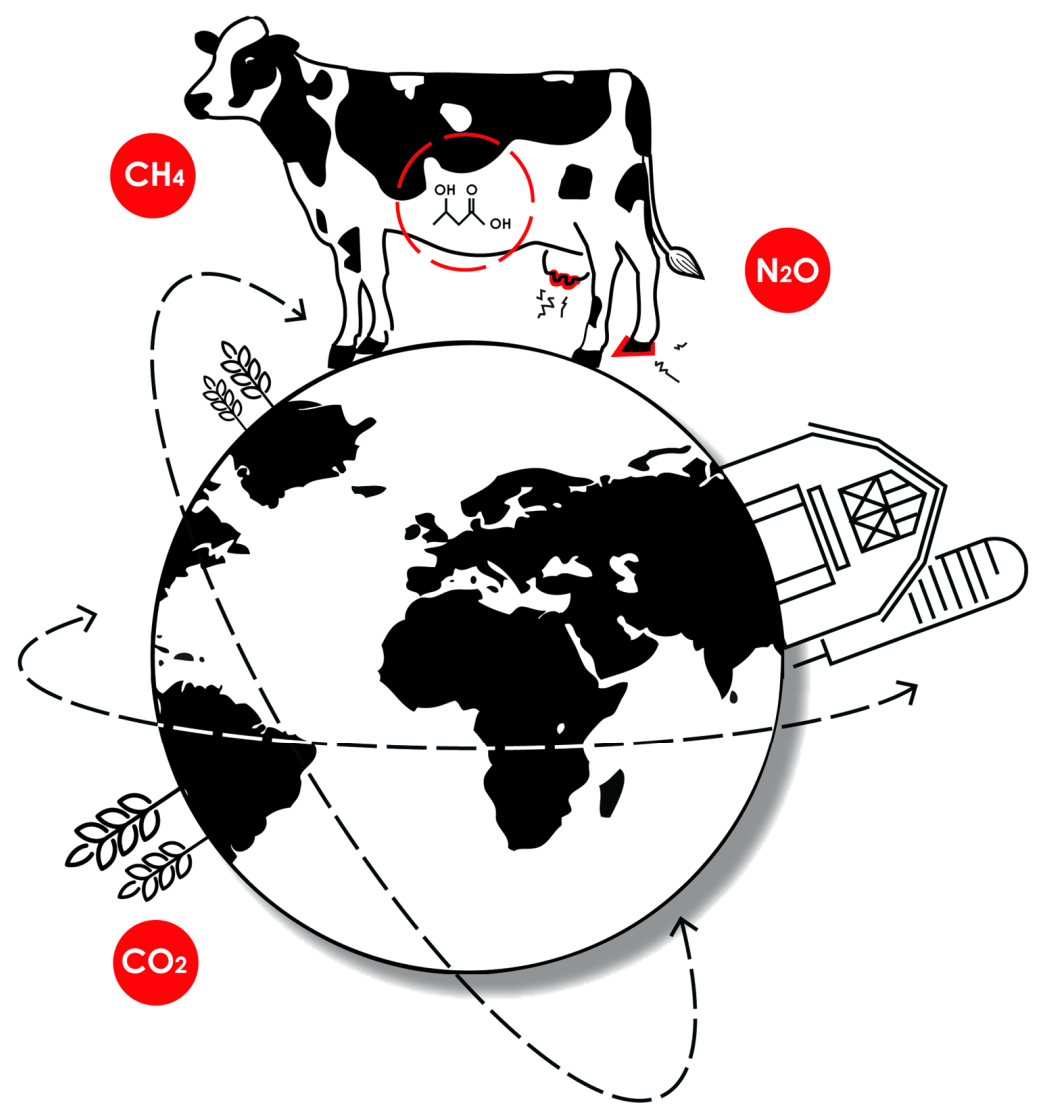


16 | Chapter 2

\section{Abstract}

The dairy sector is an important contributor to greenhouse gas (GHG) emissions. Subclinical ketosis (SCK), a metabolic disorder in dairy cows, increases the risk of other diseases. SCK can increase GHG emissions per kg of milk produced by reducing production efficiency of dairy herds. With an expected increase in milk consumption, and potential new policies to reduce GHG emissions from agriculture, producing efficiently and reducing GHG emissions becomes increasingly important. The objective of this study was to estimate the impact of SCK and related diseases (i.e. mastitis, metritis, displaced abomasum, lameness, and clinical ketosis) on GHG emissions of milk production. To this end, a dynamic stochastic simulation model was developed and combined with life cycle assessment (LCA). This model simulates the dynamics of SCK and related diseases, and the associated production losses (reduced milk production, discarded milk, a prolonged calving interval, and removal (culling or dying on the farm) per cow during one lactation. Subsequently, an LCA was performed to quantify the impact of SCK and related diseases on GHG emissions per ton fat-and-protein-corrected milk ( $\mathrm{kg} \mathrm{CO}_{2}$ equivalents/t FPCM) from cradle to farm gate. The emissions of GHGs increased on average by $20.9 \mathrm{~kg} \mathrm{CO}_{2} \mathrm{e} / \mathrm{t} \mathrm{FPCM}$ per case of SCK, with a range between 6.8 and 48.0 (5-95 percentiles). This increase in emissions was caused by a prolonged calving interval (31\%), discarded milk (30\%), reduced milk production (19\%), and removal of cows (20\%). Most cows had SCK only (61\%); for these cows emissions increased by $7.9 \mathrm{~kg} \mathrm{CO}_{2} \mathrm{e} / \mathrm{t}$ FPCM, whereas emissions of cows that died on farm increased by 463.0 $\mathrm{kg} \mathrm{CO}_{2} \mathrm{e} / \mathrm{t}$ FPCM. Sensitivity analysis showed that the disease incidence, removal risk, relations of SCK with other diseases, and emission factors related to feed production, enteric fermentation, and manure resulted in a high variation of GHG emissions. This study is the first study that estimated the impact of SCK on GHG emissions and showed the relation between cow health and GHG emissions of milk production. 


\section{Introduction}

Subclinical ketosis (SCK) in dairy cows is a metabolic disorder that occurs in the period around calving. In this period, the energy requirement of the cow can exceed her energy intake, resulting in a negative energy balance (NEB) (Grummer, 1995). An NEB results in an increase of nonesterified fatty acids and beta-hydroxybutyrate levels in the blood. A cow is considered to have SCK when the beta-hydroxybutyrate level is higher than 1.2-1.4 mmol/l blood, but shows no clinical signs of ketosis (Raboisson et al., 2014). The prevalence of SCK in European dairy cows varies between 11 and 49\% (Berge and Vertenten, 2014; Suthar et al., 2013). SCK increases the risk of other diseases, e.g. displaced abomasum (DA), metritis, mastitis, lameness and clinical ketosis (Berge and Vertenten, 2014; Raboisson et al., 2014). SCK and these related diseases can reduce milk production, reproduction performance, longevity, and increase the amount of discarded milk (McArt et al., 2012; Raboisson et al., 2014). The economic impact of this reduction in production has been estimated at $€ 257$ (Raboisson et al., 2015) and \$289 (McArt et al., 2015) per case of SCK. A common method to estimate the costs of diseases in dairy cows is dynamic stochastic simulation modelling (Bruijnis et al., 2010; Huijps and Hogeveen, 2007), which simulates diseases and production of a cow over time and shows the variation in results (Dijkhuizen et al., 1997). Studies on the environmental impact of SCK in dairy herds, however, are lacking.

One of the most urgent environmental issues is global warming, induced by greenhouse gas (GHG) emissions. The livestock sector is responsible for about 14.5\% of anthropogenic GHG emissions globally (Gerber et al., 2013). In Western Europe, the annual emissions of the livestock sector is over 0.6 gigatonnes of $\mathrm{CO}_{2}$ equivelents $\left(\mathrm{CO}_{2} \mathrm{e}\right)$, which is $9 \%$ of the global emissions of this sector. About one third of these emissions is ascribed to milk production (Gerber et al., 2013). Important GHGs related to milk production are carbon dioxide $\left(\mathrm{CO}_{2}\right)$, methane $\left(\mathrm{CH}_{4}\right)$, and nitrous oxide $\left(\mathrm{N}_{2} \mathrm{O}\right)$, mainly emitted during enteric fermentation, feed production and manure management. With an expected increase in milk consumption of $58 \%$ in 2050 compared to 2010 (FAO, 2011), producing efficiently and reducing GHG emissions per kg milk becomes increasingly relevant.

To assess the environmental impact of SCK, life cycle assessment (LCA) can be used. LCA is a method that assesses the environmental impact of a product by taking into account its entire life cycle (Baumann and Tillmann, 2004). Many studies have used LCA to estimate GHG emissions of milk production, by summing emissions of GHGs along the production chain into carbon dioxide equivalents $\left(\mathrm{CO}_{2} \mathrm{e}\right)$. Based on a literature review, De Vries and de Boer (2010) showed that GHG 
$\mathbf{1 8}$ | Chapter 2

emissions of milk produced in western countries varies from $0.84-1.3 \mathrm{~kg} \mathrm{CO}_{2} \mathrm{e}$ per $\mathrm{kg}$ milk at the farm gate. LCA has also been used to compare conventional and organic dairy systems (Cederberg and Mattsson, 2000) and to evaluate the impact of strategies to reduce GHG emissions, including breeding (Van Middelaar et al., 2014a), and feeding strategies (Van Middelaar et al., 2014b). So far, no LCA study has focused on the impact of SCK on GHG emissions of dairy production. SCK reduces feed efficiency ( $\mathrm{kg}$ feed intake/kg milk) of dairy cows, and therefore affects GHG emissions related to feed production (production of inputs, e.g. fertilizers, cultivation, and processing stages), enteric fermentation (i.e. digestion of the feed by the cow), and manure management per unit of milk produced. Furthermore, an increased removal rate, results in additional breeding of replacement heifers, which increases emissions related to non-productive animals. The increasing attention for climate change might result in policies or other incentives to reduce the impact of the dairy sector on GHG emissions. While other strategies to reduce GHG emissions might impair farmer income or cow welfare, preventing SCK, improves both. Therefore, reducing SCK is likely to not only reduce GHG emissions, but to improve the overall sustainability of the dairy sector.

The objective of this study was to estimate the impact of SCK in dairy cows on GHG emissions per unit of milk, including all processes from cradle to farm gate. This is the first study that combines environmental impact assessment using LCA, with production losses of diseases on cow level using dynamic stochastic simulation modelling. This approach enables decision making to improve dairy cow health, while reducing the environmental impact of milk production.

\section{Material and methods}

A dynamic stochastic simulation model was developed and combined with LCA to estimate the impact of SCK on GHG emissions per unit of milk produced. The model simulates the dynamics and losses of SCK and related diseases after calving for one lactation, and subsequently estimates the impact on GHG emissions using LCA. The model simulates cows on a predefined dairy farm applying limited grazing $(8 \mathrm{~h} / \mathrm{d}, 17 \mathrm{O} / \mathrm{yr})$, which is a common strategy on commercial dairy farms in Western Europe, especially in the Netherlands (CBS, 2014).

The model contains four parts (Figure 1). The first three parts are describing the dynamic stochastic simulation model and part four describes the LCA model. In part one, cow characteristics are simulated. In part two, the dynamics of SCK and related diseases are simulated. In part three, losses due to those diseases simulated in the second part are estimated. In part four, GHG 
emissions of SCK and related diseases are calculated. All four parts are described in full detail below and equations are described in electronic supplementary material (equations A.1-A.8). All input values in the model were based on literature. The model was developed in R (R_Core_Team, 2016) and results presented are based on 1,000,00o model iterations.

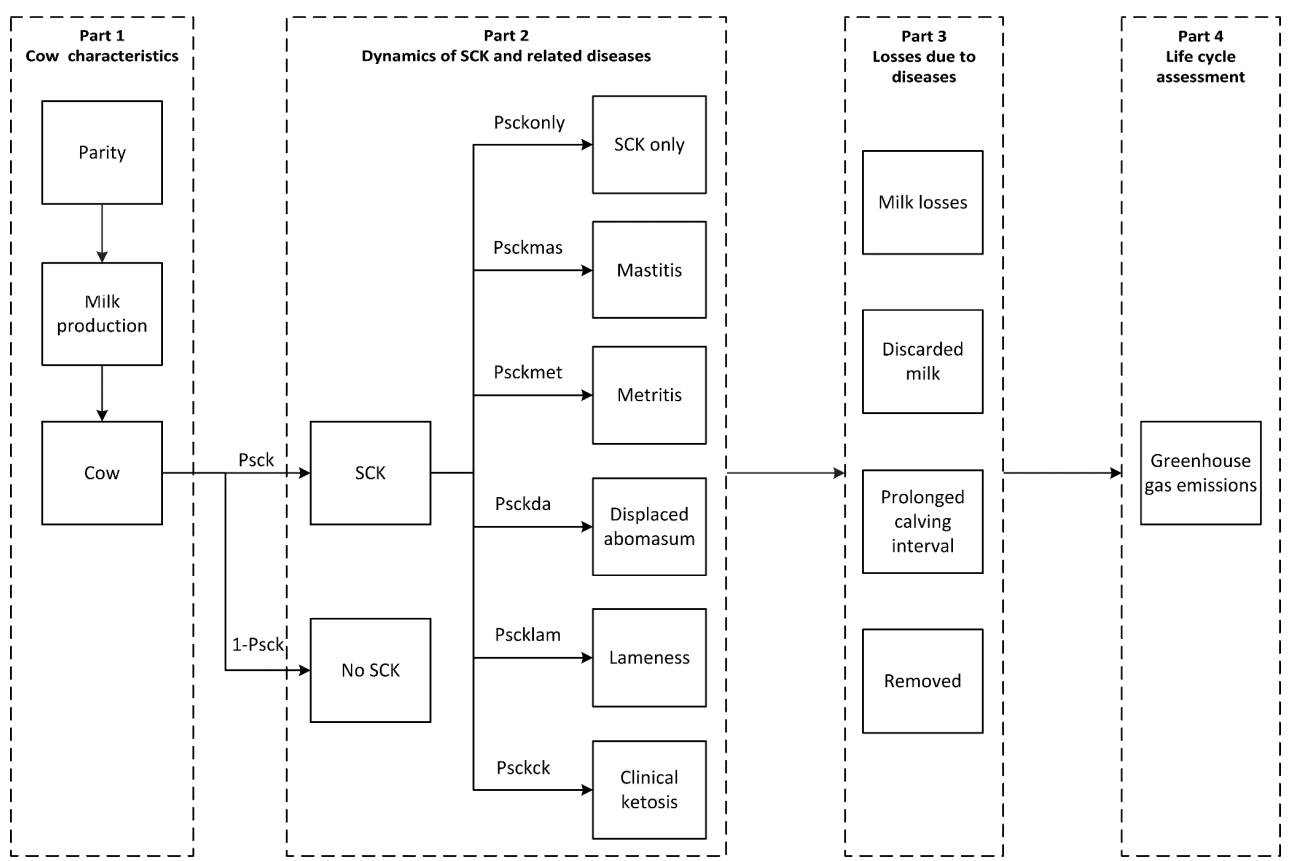

Figure 1. Overview of the four parts of the model to estimate the impact of subclinical ketosis (SCK) on greenhouse gas emissions. $\mathrm{P}=$ probability.

\section{Cow characteristics (part 1)}

Each cow receives a parity (1-5+), which is the number of parturitions (calving's) of a cow, based on the average herd composition in the Netherlands (CRV, 2014). Based on the parity, the cow receives a body weight, a milk production level, and a calving interval (CI) (CRV, 2014; CVB, 2012) (Table 1). Milk production level per parity is determined with a normal distribution function to get natural variation among the cows (CRV, 2014). The calving interval consists of a lactation period (350-361 d) and a dry-period (6o d), representing common practice in the Netherlands and other Western European countries. A lactation curve is utilized to estimate the average daily milk production per cow based on weekly milk records (Wood, 1967). 
20 | Chapter 2

Table 1. Cow characteristics and probabilities of diseases per parity to estimate the environmental impact of subclinical ketosis (SCK) in dairy cows.

\begin{tabular}{|c|c|c|c|c|c|c|}
\hline Input value & Parity 1 & Parity 2 & Parity 3 & Parity 4 & Parity $5+$ & Source \\
\hline Cows (\%) & 33 & 27 & 17 & 11 & 12 & CRV (2014) \\
\hline Milk production $(\mathrm{kg})$ (mean/ 305d) & 7535 & 8788 & 9383 & 9493 & 9209 & CRV (2014) \\
\hline Calving interval (d) & 410 & 413 & 415 & 419 & 421 & CRV (2014) \\
\hline Weight cow (kg) & 540 & 595 & 650 & 650 & 650 & CVB (2012) \\
\hline \multicolumn{7}{|l|}{ Subclinical ketosis } \\
\hline Probabilitya SCK (\%) & 19.8 & 23.5 & 28.5 & 32.0 & 31.3 & Berge and Vertenten (2014) \\
\hline Milk losses (d 1-30) (\%) & 7.0 & 7.0 & 7.0 & 7.0 & 7.0 & Adapted from McArt et al. (2012) \\
\hline \multicolumn{7}{|l|}{ Mastitis } \\
\hline Ad. Probability ${ }^{\mathrm{b}}(\%)$ & 6.6 & 9.1 & 8.6 & 1.6 & 20.2 & Berge and Vertenten (2014) \\
\hline Milk loss (d31-el') (\%) & 5.0 & 5.0 & 5.0 & 5.0 & 5.0 & Seegers et al. (2003) \\
\hline Culling probability ${ }^{d}(\%)$ & 0.0 & 1.9 & 4.6 & 8.3 & 8.3 & Bar et al. (2008) \\
\hline Death probability ${ }^{d}(\%)$ & 1.5 & 1.2 & 2.8 & 3.9 & 3.9 & Bar et al. (2008) \\
\hline \multicolumn{7}{|l|}{ Metritis } \\
\hline Ad. probability (\%) & 7.3 & 4.4 & 2.2 & 2.0 & 6.4 & Berge and Vertenten (2014) \\
\hline Milk loss (d 31-60) (\%) & 3.8 & 3.8 & 3.8 & 3.8 & 3.8 & Gröhn et al. (2003); Rajala and Gröhn (1998) \\
\hline \multicolumn{7}{|l|}{ Displaced abomasum } \\
\hline Ad. probability (\%) & 3.7 & 6.9 & 15.1 & 3.7 & 0.0 & Berge and Vertenten (2014) \\
\hline Milk loss (in 305 d) ${ }^{\mathrm{e}}(\%)$ & 3.3 & 4.7 & 4.7 & 4.7 & 4.7 & Raizman et al. (2002) \\
\hline Culling probability (\%) & 1.7 & 1.3 & 3.2 & 5.8 & 5.8 & Bar et al. (2008) \\
\hline Death probability (\%) & 1.0 & 1.0 & 2.4 & 3.3 & 3.3 & Bar et al. (2008) \\
\hline \multicolumn{7}{|l|}{ Lameness } \\
\hline Ad. probability (\%) & 1.3 & 0.3 & 6.9 & 10.3 & 0.0 & Berge and Vertenten (2014) \\
\hline Milk loss (d31- el) (\%) & 5.7 & 5.7 & 5.7 & 5.7 & 5.7 & Raboisson et al. (2014) \\
\hline Culling probability (\%) & 4.0 & 4.0 & 4.0 & 4.0 & 4.0 & Bruijnis et al. (2010) \\
\hline \multicolumn{7}{|l|}{ Clinical ketosis } \\
\hline Ad. probability (\%) & 10.5 & 11.4 & 21.4 & 21.0 & 21.9 & Berge and Vertenten (2014) \\
\hline Death probability (\%) & 0.0 & 0.7 & 1.7 & 2.5 & 2.5 & Bar et al. (2008) \\
\hline
\end{tabular}

a Probabilities were obtained and calculated from data of the study Berge and Vertenten (2014)

${ }^{b}$ Ad. probability: Additional probability of cow getting a disease with SCK were obtained and calculated from data of the study Berge and Vertenten (2014); probabilities were estimated as the difference between the probability of the cow getting the disease with SCK and the probability of the cow getting the disease without SCK

${ }^{\mathrm{c}}$ End of lactation period

d Additional probability on getting culled or death on farm were calculated for the disease

e Reduced milk production losses for displaced abomasum were estimated over 305 days but only occurred in months 1-4. Daily milk loss (kg/day) was estimated and reduced milk production losses occurred after day 30. 


\section{Dynamics of SCK and related diseases (part 2)}

The model includes SCK and related diseases mastitis, metritis, DA, lameness, and clinical ketosis which occur in the first 30 days after calving (Table 2). Each cow receives a probability to get SCK at day 5 after calving. Cows with SCK subsequently receive an additional probability to get mastitis, metritis, DA, lameness or clinical ketosis (Table 1). All probabilities are parity specific and computed based on data of Berge and Vertenten (2014) and disease incidence at herd level found in literature (Table 2). The additional probability of getting a related disease because of SCK was estimated as the difference between the probability of getting this disease with SCK and the probability of getting this disease without SCK. It was assumed that only cows with SCK could get clinical ketosis. Each cow with SCK and a related disease receives a parity specific probability to get culled or to die on the farm, referred to as removal (Table 1). Data of removal were based on a study that analysed the removal rates of several diseases in the first two months. In the model, the day of removal was set at day 30 . In practice cows might be removed at a later stage of the lactation (e.g. due to fertility problems). No data, however, were available to include this based on disease in the model. The discrete events of getting SCK, a related disease after SCK, and removal from the herd are simulated by using random numbers drawn from uniform distributions to assign cows to different categories.

Table 2. Disease incidence and consequences on production parameters used to estimate the environmental impact of subclinical ketosis (SCK) and related diseases in dairy cows.

\begin{tabular}{|c|c|c|c|c|c|}
\hline Disease & $\begin{array}{c}\text { Total } \\
\text { incidence }^{\mathrm{a}}(\%)\end{array}$ & $\begin{array}{c}\text { Day of occurrence } \\
\text { in lactation }\end{array}$ & $\begin{array}{c}\text { Days of } \\
\text { discarded milk }\end{array}$ & $\begin{array}{l}\text { Prolonged calving } \\
\text { interval (days) }\end{array}$ & Source \\
\hline Subclinical ketosis & 25.0 & 5 & 0 & 19 & $\begin{array}{l}\text { McArt et al. (2012); Raboisson et } \\
\text { al. (2015); Walsh et al. (2007) }\end{array}$ \\
\hline Clinical ketosis & 4.0 & 13 & 3.5 & 6 & $\begin{array}{l}\text { Duffield et al. (2009); Fourichon et } \\
\text { al. (2000) }\end{array}$ \\
\hline Mastitis & 12.5 & 8 & 6 & 28 & $\begin{array}{l}\text { Santos et al. (2004); Wilson et al. } \\
\text { (2004) }\end{array}$ \\
\hline Metritis & 10.2 & 10 & 7 & 18 & $\begin{array}{l}\text { Fourichon et al. (2000); Giuliodori } \\
\text { et al. (2013); Overton and Fetrow } \\
\text { (2008) }\end{array}$ \\
\hline Displaced abomasum & 4.0 & 10 & 7 & 15 & $\begin{array}{l}\text { Duffield et al. (2009); Jorritsma et } \\
\text { al. (2008); McArt et al. (2012); } \\
\text { Raizman et al. (2002) }\end{array}$ \\
\hline Lameness & 4.5 & 8 & 0 & 12 & $\begin{array}{l}\text { Bruijnis et al. (2010); Fourichon et } \\
\text { al. (2000) }\end{array}$ \\
\hline
\end{tabular}

a Total disease incidence in the first 30 days after calving in the herd

\section{Losses due to diseases (part 3)}

Table 1 shows milk losses related to SCK and related diseases. The reduction in milk production during the first 30 days of lactation was assumed to be the same for all cows with SCK, regardless 
the related disease. Reduction in milk production after 30 days was disease specific. Cows with a related disease receive treatment, which was disease specific and based on the average treatment protocol of seven randomly selected veterinarians in the Netherlands, and on information from literature. If the cow is administered antibiotics, the milk is discarded for the prescribed days (Table 2). Cows that are removed were assumed to be replaced by a heifer with average production parameters. Differences in milk production between the removed cow and the new heifer were taken into account. The impact on fertility was assumed to be disease specific and modelled by prolonging the CI of the cow, while the dry period remained unchanged (Table 2). The prolonged CI depends on the (combination of) disease(s). Since no data were available on the combined effect of SCK and related diseases on CI, the impact on CI was determined by adding all the extra days of the disease with the largest effect on CI, and half of the extra days of the other disease, which was adapted from the method of Gröhn et al. (2003).

\section{Estimation of GHG emissions (part 4)}

An LCA was performed including output of part one to three of the dynamic stochastic simulation model to estimate the impact of SCK on GHG emissions. Emissions of $\mathrm{CO}_{2}, \mathrm{CH}_{4}$, and $\mathrm{N}_{2} \mathrm{O}$ are estimated from cradle to farm gate for processes along the milk production chain that were affected by SCK. Processes included were feed production, enteric fermentation, and manure management. SCK affects all these processes. The emissions related to the production of antibiotics were assumed to be minor and were therefore excluded (Hospido and Sonesson, 2005). The estimation of GHG emissions was conducted following IPCC methods (IPCC, 2006). If available, emission factors were based on national inventory reports.

Emissions related to feed production and enteric fermentation depend on diet composition and feed intake. Diet composition in the summer and winter period was based on national statistics of the Netherlands (Table B.1; Table B.3, of the electronic supplementary material). Feed intake (kg $\mathrm{DM} / \mathrm{cow}$ ) was estimated based on the energy content of the diet (Table 3) and the daily energy requirements of the cow. Energy requirements for maintenance (including a correction for grazing), milk production, pregnancy, and growth in case of parity 1 and 2 were taking into account (CVB, 2012). The energy requirements for maintenance were the same for cows with or without a disease, while the energy requirement for milk production changed with a change in milk yield. As a result, cows with SCK were found to have a lower feed efficiency and a higher energy requirement per kg of milk produced. 
Emissions of GHGs related to feed production were based on Vellinga et al. (2013), and included emissions from the production of inputs (e.g. fertilizers, energy), crop cultivation, processing and drying of the feed ingredients, and transport to the farm (Table 3, Table B.2 of the electronic supplementary material). In addition to the processes described above, emissions related to land use (LU) and land use change (Luc) were also included.

Emissions from enteric fermentation were based on Vellinga et al. (2013), using feed specific emission factors derived from a mechanistic simulation model of rumen fermentation processes (Bannink et al., 2008; Bannink et al., 2010) (Table 3, Table B.2 of the electronic supplementary material).

Emissions from manure were estimated based on national inventory reports and IPCC. Nitrogen excretion was estimated based on nitrogen intake of the cow and nitrogen that is retained for milk production, and for growth of the cow and calf. Direct $\mathrm{N}_{2} \mathrm{O}$ and $\mathrm{CH}_{4}$ emissions from manure in stables, storage, and on grass were based on national inventory reports (De Mol and Hilhorst, 2003; De Vries et al., 2011; Vonk et al., 2016). Indirect $\mathrm{N}_{2} \mathrm{O}$ emissions (i.e., $\mathrm{N}_{2} \mathrm{O}$ derived from volatilization of ammonia $\left(\mathrm{NH}_{3}\right)$ and nitrogen oxides $\left(\mathrm{NO}_{\mathrm{x}}\right)$ and from leaching of nitrate $\left(\mathrm{NO}_{3}\right)$ ) were also based on national inventory reports (De Mol and Hilhorst, 2003; De Vries et al., 2011; Velthof and Mosquera, 2011; Vonk et al., 2016) and IPCC (2006). More details about calculation of emissions from manure can be found in the electronic supplementary material (Table C.1).

System expansion was applied to account for the impact of SCK and related diseases on the production of meat from calves and cows relative to the amount of milk produced. Consequences of meat production in terms of GHG emissions were based on the so-called avoided-burden method (Guinée et al., 2002; Thomassen et al., 2008). Meat from culled calves and cows replaces

Table 3. Greenhouse gas emissions of feed production and land use and land use change (LULuc), enteric methane emissions, and nitrogen content of feed ingredients.

\begin{tabular}{|c|c|c|}
\hline Input variable ${ }^{a}$ & Summer diet & Winter diet \\
\hline Energy of feed (MJ/ kg DM) & 6.8 & 6.5 \\
\hline Nitrogen content (g /kg DM) & 30.3 & 26.8 \\
\hline Feed production ( $\left.\mathrm{g} \mathrm{CO}_{2} \mathrm{e} / \mathrm{kg} \mathrm{DM}\right)$ & 470 & 468 \\
\hline LULuc (g CO 2 e /kg DM) & 87 & 94 \\
\hline Enteric methane ( $\left.\mathrm{g} \mathrm{CH}_{4} / \mathrm{kg} \mathrm{DM}\right)$ & 20.9 & 20.5 \\
\hline
\end{tabular}

a Vellinga et al., 2013 


\section{4 | Chapter 2}

alternative products on the market, and therefore subtracts GHG emissions related to the production of those avoided products from the emissions related to dairy production. We assumed that meat from calves and cows replaces meat from chicken, pork or beef. Emissions of GHGs related to the production of meat from chicken (5.6 $\mathrm{kg} \mathrm{CO}_{2} \mathrm{e} / \mathrm{kg}$ edible product), pork $\left(7.3 \mathrm{~kg} \mathrm{CO}_{2} \mathrm{e} /\right.$ $\mathrm{kg}$ edible product) or beef (23.4 $\mathrm{kg} \mathrm{CO}_{2} \mathrm{e} / \mathrm{kg}$ edible product) (Van Middelaar et al., 2014a) were weighted to an average emission factor $\left(10 \mathrm{~kg} \mathrm{CO}_{2} \mathrm{e} / \mathrm{kg}\right.$ edible product) based on the average consumption of chicken ( $28 \mathrm{~kg}$ ), pork (22 kg), and beef (14 kg) per capita in OECD countries (OECD, 2015). For culled cows (540-650 kg live weight) and calves (44 kg live weight), it was assumed that $1 \mathrm{~kg}$ of animal live weight consisted of $0.406 \mathrm{~kg}$ edible product (Van Middelaar et al., 2014a).

Cows that were removed before the end of parity 5 were assumed to be removed too early, resulting in additional GHG emissions for raising extra heifers. For this, we first calculated the emissions of GHGs from raising a heifer (5342 $\mathrm{kg} \mathrm{CO}_{2} \mathrm{e}$ ). Energy and feed requirements of young stock were based on general recommendations for a Dutch situation (CVB, 2012; Remmelink et al., 2014). It was assumed that the heifer grazed for 170 days per year from the age of three months and calved for the first time after two years. The amount of GHG emissions related to raising a heifer for milk production, was the difference between emissions of raising a heifer and GHG emissions for the alternative production of meat from that heifer $\left(2195 \mathrm{~kg} \mathrm{CO}_{2} \mathrm{e}(540 \mathrm{~kg}\right.$ x $0.406 \mathrm{~kg}$ edible product x $10 \mathrm{~kg} \mathrm{CO} 2 \mathrm{e} / \mathrm{kg}$ edible product)), resulting in an emission factor of $3147\left(5342 \mathrm{~kg} \mathrm{CO}_{2} \mathrm{e}-2195 \mathrm{~kg}\right.$ $\left.\mathrm{CO}_{2} \mathrm{e}\right) \mathrm{kg} \mathrm{CO} 2 \mathrm{e}$ per heifer.

Second, additional GHG emissions for removal are estimated with a depreciation method. Emissions of GHGs related to raising a heifer for milk production were depreciated over the total amount of milk that was produced by the cow at the moment of removal compared to the expected amount of milk at the end of parity 5 . For cows that were removed at parity $2+$, average milk production levels were assumed for all previous parities. The meat of cows that died on farm had no value and did not replace any other meat product. Therefore, the GHG emissions for the alternative production of meat from these cows were not subtracted.

Emissions of GHGs were estimated for cows with SCK (and related diseases) and without SCK and were expressed as $\mathrm{kg} \mathrm{CO}_{2}$ equivalents $\left(\mathrm{CO}_{2} \mathrm{e}\right)$ per ton of fat-and-protein-corrected milk (FPCM). Different GHGs were summed up based on their equivalent factor: 1 for $\mathrm{CO}_{2}, 28$ for biogenic $\mathrm{CH}_{4}$, 30 for fossil $\mathrm{CH}_{4}$, and 265 for $\mathrm{N}_{2} \mathrm{O}$ (100-year time horizon) (Myhre et al., 2013). The impact of SCK on GHG emissions was the difference in emissions per kg FPCM between a cow with SCK (and 
related diseases) and without SCK. To gain insight into the largest contributors, the impact of SCK (and related diseases) on GHG emissions was analyzed per process (feed production, enteric methane production, manure), per parity, per production contributor (reduced milk production, discarded milk, prolonged CI, removal), and per disease combination.

\section{Sensitivity analysis}

Two sensitivity analyses were performed. First, to analyse the impact of changes in input parameters of diseases. Second, to analyse the impact of input parameters of GHG emissions. Both were compared with the results of the reference situation (Table 1, 2, 3). All the input parameters were adjusted and analysed separately.

Probabilities of getting mastitis, metritis, DA, lameness, or clinical ketosis were increased and decreased by 50\% (P per disease). Probabilities of removal were doubled (Increased P removal). The risk ratio (RR) and removal probabilities of metritis and DA were increased based on values found in literature. The RR of metritis for cows with SCK was increased from 1.4 to 3.3 (Increased risk ratio metritis) (Duffield et al., 2009). The RR of DA for cows with SCK was increased from 3.7 to 8.o (Increased risk ratio DA) (LeBlanc et al., 2005). Furthermore, in each parity removal probability of DA and metritis were increased to $23.4 \%$ (DA) and to $6.0 \%$ (metritis) (Increased P removal metritis and $D A$ ) (Overton and Fetrow, 2008; Raizman et al., 2002).

The impact of changes in input parameters on GHG emissions were analysed to assess the potential impact of differences in feeding strategy, feed composition, and manure management between farms, and to assess the impact of uncertainty of the GHG emission factors that were used. Based on variation found in literature, the most important emission factors were changed. Emissions related to the production of feed were changed by $\pm 25 \%$ (Emissions feed) (Van Middelaar et al., 2013). Emissions related to enteric fermentation were changed by $\pm 20 \%$ (Emissions enteric) (IPCC, 2006). Emissions related to raising a heifer were changed by $\pm 25 \%$ (Emissions heifer). Emissions of $\mathrm{CH}_{4}$ and $\mathrm{N}_{2} \mathrm{O}$ related to manure storage and grazing were changed by $\pm 100 \%$ (Emissions manure) (Olivier et al., 2009). Emissions related to LULuc were changed by $\pm 50 \%$ (Emissions LULuc) (Vellinga et al., 2013). 
26 | Chapter 2

\section{Results}

\section{Impact of SCK on GHG emissions of milk}

The emissions of GHGs increased on average by $20.9 \mathrm{~kg} \mathrm{CO}_{2} \mathrm{e} / \mathrm{t}$ FPCM per case of SCK, with a range between 6.8 and 48.0 (5-95 percentiles). Feed production and enteric fermentation had the highest impact on the total emissions (Table 4). With regard to the production contributors, the increase in emissions of GHGs per case of SCK resulted for $31 \%$ from prolonged CI, for $30 \%$ from discarded milk, for $19 \%$ from reduced milk production, and for $20 \%$ from removal. The increase of emissions of GHGs per case of SCK varied on average from 15.1 (6.5-44.5) in parity 1, to 27.7 (7.048.0) in parity 3 (Table 5).

Table 4. Greenhouse gas emissions ( $\mathrm{kg} \mathrm{CO}_{2} \mathrm{e} / \mathrm{t}$ FPCM) of a cow with no SCK, a cow with SCK, and the difference related to feed production, enteric methane, land use and land use change (LULuc), manure, and removal.

\begin{tabular}{|c|c|c|c|}
\hline & No SCK & SCK & Difference \\
\hline \multicolumn{4}{|l|}{$\mathrm{CO}_{2}$} \\
\hline Feed production & 196.9 & 200.6 & 3.7 \\
\hline LULuc & 67.2 & 68.4 & 1.3 \\
\hline \multicolumn{4}{|l|}{$\mathrm{CH}_{4}$} \\
\hline Feed production & 2.8 & 2.8 & 0.1 \\
\hline Enteric fermentation & 427.1 & 435.1 & 8.0 \\
\hline Manure & 44.4 & 44.6 & 0.3 \\
\hline \multicolumn{4}{|l|}{$\mathrm{N}_{2} \mathrm{O}$} \\
\hline Feed production & 146.7 & 149.5 & 2.7 \\
\hline Manure & 46.2 & 47.4 & 1.2 \\
\hline Total before correction & 931.2 & 948.4 & 17.2 \\
\hline Avoided burden ${ }^{\mathrm{a}}$ & -8.4 & -8.4 & -0.1 \\
\hline Add. removal ${ }^{b}$ & & 3.8 & 3.8 \\
\hline Total after correction & 922.8 & 943.7 & 20.9 \\
\hline \multicolumn{4}{|c|}{$\begin{array}{l}\text { a Emissions are corrected for meat production of the cows based on system expansion. Meat from cows replaces } \\
\text { alternative products on the market, and therefore the GHG emissions of meat from cows is equal to the GHG } \\
\text { emissions of the alternative product. }\end{array}$} \\
\hline
\end{tabular}


Table 5. Average increase of greenhouse gas (GHG) emissions $\left(\mathrm{kg} \mathrm{CO}_{2} \mathrm{e} / \mathrm{t} \mathrm{FPCM}\right)$ per parity per case of subclinical ketosis (5-95 percentiles) related to reduced milk production, discarded milk, prolonged calving interval and removal.

\begin{tabular}{lcccccc}
\hline Contributor & Parity 1 & Parity 2 & Parity 3 & Parity 4 & Parity 5+ & Average $^{\text {a }}$ \\
\hline Reduced milk production & 3.7 & 4.0 & 4.7 & 3.5 & 4.1 & 4.0 \\
& $(1.9-17.1)$ & $(1.8-15.3)$ & $(1.4-15.3)$ & $(1.4-15.7)$ & $(1.5-14.9)$ & $(1.5-15.6)$ \\
Discarded milk & 4.9 & 5.8 & 8.4 & 4.1 & 8.3 & 6.2 \\
& $(0.0-22.3)$ & $(0.0-23.7)$ & $(0.0-24.0)$ & $(0.0-23.0)$ & $(0.0-23.0)$ & $(0.0-23.5)$ \\
Prolonged calving interval & 4.9 & 7.3 & 7.0 & 6.6 & 7.6 & 6.5 \\
& $(4.1-8.2)$ & $(5.8-12.9)$ & $(5.5-12.2)$ & $(5.5-8.8)$ & $(5.6-13.5)$ & $(4.2-12.3)$ \\
Removal & 0.0 & 0.1 & 0.7 & 0.6 & 0.9 & 0.4 \\
& $(0.0-0.0)$ & $(0.0-0.0)$ & $(0.0-0.0)$ & $(0.0-0.0)$ & $(0.0-0.0)$ & $(0.0-0.0)$ \\
Total before correction & 13.5 & 17.2 & 20.9 & 14.7 & 20.9 & 17.2 \\
& $(6.0-44.4)$ & $(7.7-49.0)$ & $(7.1-47.4)$ & $(7.0-39.8)$ & $(7.3-50.0)$ & $(6.4-47.6)$ \\
Avoided burden ${ }^{b}$ & 0.4 & 0.1 & -0.4 & -0.3 & -0.6 & -0.1 \\
Add. removalc & $(-0.1-0.6)$ & $(-0.5-0.3)$ & $(-0.1-0.1)$ & $(-0.1-0.1)$ & $(-0.1-0.1)$ & $(-0.4-0.6)$ \\
& 1.1 & 2.0 & 7.3 & 4.5 & 6.2 & 3.8 \\
Total after correction & $(0.0-0.0)$ & $(0.0-0.0)$ & $(0.0-0.0)$ & $(0.0-0.0)$ & $(0.0-0.0)$ & $(0.0-0.0)$ \\
& 15.1 & 19.3 & 27.7 & 18.9 & 26.6 & 20.9
\end{tabular}

a A weighted average for all parities was taken which was based on the composition of an average Dutch dairy herd

b Emissions are corrected for meat production of the cows based on system expansion. Meat from cows replaces alternative products on the market, and therefore the GHG emissions of meat from cows is equal to the GHG emissions of the alternative product.

${ }^{c}$ Additional emissions because cows are removed too early resulting in additional GHG emissions for raising extra replacement heifers

Most cows had SCK only (61\%); for these cows emissions of GHGs increased by 7.9 (6.7-9.4) kg $\mathrm{CO}_{2} \mathrm{e} / \mathrm{t}$ FPCM per case. Emissions of GHGs of cows with SCK and a related disease, that were not removed from the herd, increased on average by 31.4 (18.5-49.6) $\mathrm{kg} \mathrm{CO}_{2} \mathrm{e} / \mathrm{t}$ FPCM per case. Emissions of GHGs increased by $6.9 \%$ for cows with SCK and mastitis, 3.7\% for cows with SCK and metritis, $6.0 \%$ for cows with SCK and DA, 3.4\% for cows with SCK and lameness, and $2.9 \%$ for cows with clinical ketosis (Table 6).

Emissions of GHGs of cows with SCK that were culled increased on average by 188.2 (92.7-320.4) $\mathrm{kg} \mathrm{CO}_{2} \mathrm{e} / \mathrm{t}$ FPCM per case, whereas the emissions of GHGs of cows with SCK that died on farm increased on average by $463.0(361.5-571.1) \mathrm{kg} \mathrm{CO}_{2} \mathrm{e} / \mathrm{t}$ FPCM per case. 
Table 6. Average increase of greenhouse gas (GHG) emissions (kg $\mathrm{CO}_{2} \mathrm{e} / \mathrm{t}$ FPCM) (5-95 percentiles) per case of subclinical ketosis (SCK) only, SCK and mastitis, SCK and metritis, SCK and displaced abomasum (DA), SCK and lameness, and clinical ketosis related to reduced milk production, discarded milk, prolonged calving interval and removal.

\begin{tabular}{|c|c|c|c|c|c|c|}
\hline Contributor & SCK only & $\mathrm{SCK}+$ mastitis & $\mathrm{SCK}+$ metritis & $\mathrm{SCK}+\mathrm{DA}$ & SCK + lameness & Clinical ketosis \\
\hline Reduced milk production & $\begin{array}{c}2.0 \\
(1.5-2.4)\end{array}$ & $\begin{array}{c}14.3 \\
(2.2-18.4)\end{array}$ & $\begin{array}{c}3.1 \\
(2.5-3.7)\end{array}$ & $\begin{array}{c}9.5 \\
(7.6-11.8)\end{array}$ & $\begin{array}{c}15.8 \\
(13.4-20.3)\end{array}$ & $\begin{array}{c}1.8 \\
(1.4-2.3)\end{array}$ \\
\hline Discarded milk & $\begin{array}{c}0.0 \\
(0.0-0.0)\end{array}$ & $\begin{array}{c}20.5 \\
(19.4-21.4)\end{array}$ & $\begin{array}{c}23.0 \\
(21.7-24.2)\end{array}$ & $\begin{array}{c}23.5 \\
(22.1-24.5)\end{array}$ & $\begin{array}{c}0.0 \\
(0.0-0.0)\end{array}$ & $\begin{array}{c}11.5 \\
(10.9-12.0)\end{array}$ \\
\hline Prolonged calving interval & $\begin{array}{c}5.7 \\
(4.2-6.9)\end{array}$ & $\begin{array}{c}11.2 \\
(0.0-14.3)\end{array}$ & $\begin{array}{c}7.5 \\
(5.2-9.7)\end{array}$ & $\begin{array}{c}7.2 \\
(4.5-8.9)\end{array}$ & $\begin{array}{c}8.0 \\
(5.9-9.5)\end{array}$ & $\begin{array}{c}6.3 \\
(4.6-7.7)\end{array}$ \\
\hline Removal & $\begin{array}{c}0.0 \\
(0.0-0.0)\end{array}$ & $\begin{array}{c}1.9 \\
(0.0-19.1)\end{array}$ & $\begin{array}{c}0.0 \\
(0.0-0.0)\end{array}$ & $\begin{array}{c}1.3 \\
(0.0-0.0)\end{array}$ & $\begin{array}{c}1.2 \\
(0.0-0.0)\end{array}$ & $\begin{array}{c}0.5 \\
(0.0-0.0)\end{array}$ \\
\hline Total before correction & $\begin{array}{c}7.7 \\
(6.2-9.1)\end{array}$ & $\begin{array}{c}47.9 \\
(43.2-53.5)\end{array}$ & $\begin{array}{c}33.6 \\
(29.9-37.2)\end{array}$ & $\begin{array}{c}41.5 \\
(35.7-46.1)\end{array}$ & $\begin{array}{c}24.9 \\
(21.6-29.0)\end{array}$ & $\begin{array}{c}20.2 \\
(17.5-21.9)\end{array}$ \\
\hline Avoided burden ${ }^{a}$ & $\begin{array}{c}0.2 \\
(-0.1-0.6)\end{array}$ & $\begin{array}{c}-1.2 \\
(-18.0-0.1)\end{array}$ & $\begin{array}{c}0.1 \\
(0.0-0.4)\end{array}$ & $\begin{array}{c}-0.8 \\
(-0.6-0.1)\end{array}$ & $\begin{array}{c}-0.6 \\
(-0.5-0.1)\end{array}$ & $\begin{array}{c}-0.2 \\
(0.0-0.4)\end{array}$ \\
\hline Add. removal ${ }^{b}$ & $\begin{array}{c}0.0 \\
(0.0-0.0)\end{array}$ & $\begin{array}{c}16.7 \\
(0.0-75.3)\end{array}$ & $\begin{array}{c}0.0 \\
(0.0-0.0)\end{array}$ & $\begin{array}{c}15.0 \\
(0.0-0.0)\end{array}$ & $\begin{array}{c}7.3 \\
(0.0-0.0)\end{array}$ & $\begin{array}{c}7.0 \\
(0.0-0.0)\end{array}$ \\
\hline Total after correction & $\begin{array}{c}7.9 \\
(6.7-9.4)\end{array}$ & $\begin{array}{c}63.4 \\
(43.8-113.6)\end{array}$ & $\begin{array}{c}33.8 \\
(30.2-37.2)\end{array}$ & $\begin{array}{c}55.6 \\
(35.8-47.2)\end{array}$ & $\begin{array}{c}31.6 \\
(21.9-29.7)\end{array}$ & $\begin{array}{c}27.0 \\
(17.9-22.1)\end{array}$ \\
\hline
\end{tabular}

a Emissions are corrected for meat production of the cows based on system expansion. Meat from cows replaces alternative products on the market, and therefore the GHG emissions of meat from cows is equal to the GHG emissions of the alternative product.

b Additional emissions because cows are removed too early resulting in additional GHG emissions for raising extra replacement heifers

\section{Sensitivity analysis}

Results of the sensitivity analysis are shown in Figure 2. Increasing the probabilities of mastitis increased GHG emissions by $12 \%$ per case of SCK, whereas increasing the probabilities of clinical ketosis increased GHG emissions by $6 \%$ per case of SCK. A decrease in the probabilities of related diseases resulted in a similar but opposite effect (results not shown). A doubling of the probabilities of removal due to diseases increased GHG emissions by $16 \%$ per case of SCK.

Increasing the RR of metritis for cows with SCK increased GHG emissions by $13 \%$ per case of SCK, whereas increasing the RR of DA increased GHG emissions by 7\% per case of SCK. Increasing the removal risk of metritis and DA resulted in an increase in GHG emissions of 22\% per case of SCK.

Increasing emissions related to the production of feed increased GHG emissions by $7 \%$ per case of SCK compared to the reference situation, whereas increasing the emissions related to LULuc increased GHG emissions by $3 \%$ per case of SCK. Increasing the emissions related to enteric fermentation increased GHG emissions by $7 \%$ per case of SCK, increasing the emissions related to 
raising a heifer by $4 \%$, and increasing emissions related to manure by $6 \%$. A decrease in emission factors resulted in a similar but opposite effect (results not shown).

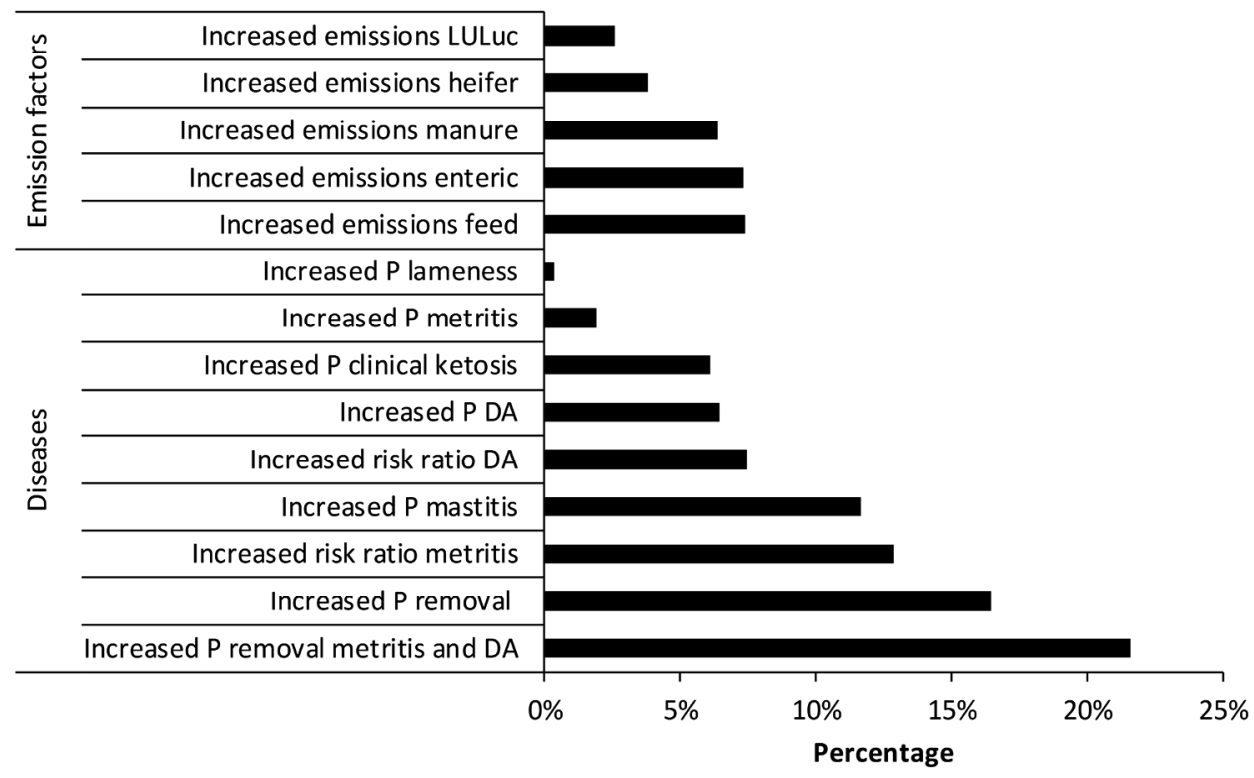

Figure 2. Results from the sensitivity analyses showing the effect (\%) of a change in input parameters of emission factors, and diseases on the impact of subclinical ketosis on greenhouse gas emissions per ton fat-and-protein-corrected milk compared to the reference situation. $\mathrm{P}=$ probability, DA=displaced abomasum, LULuc= land use and land use change.

\section{Discussion}

Our study is the first study that estimates the impact of SCK on GHG emissions of milk production. SCK increased GHG emissions on average by $2.3 \%$ per case of SCK, but showed large variation. Most cows had SCK only. For these cows, the increase in GHG emissions per unit of milk was relatively low, because they only had a reduced milk production and a prolonged CI. Cows with SCK and a related disease and cows that were removed from the herd had a relatively high increase in GHG emissions per unit of milk. These cows had a relatively large contribution to the average increase of GHG emissions per case of SCK. Cows with SCK and a related disease had a greater reduction in milk production and a longer CI than cows with SCK only, and also had discarded milk. Removal of cows leads to additional emissions for breeding extra replacement heifers. The impact of SCK on GHG emissions was highest for cows that died on the farm. 
With regard to production contributors (i.e., the importance of reduced milk production, discarded milk, prolonged CI and removal), results were mainly affected by a prolonged CI, which related to that fact that all cows with SCK had a prolonged CI. However, for cows with SCK and a related disease that was treated with antibiotics, discarded milk was found to be the most important contributor. This does not mean that cows should not be treated, because that may lead to removal of cows, resulting in an even higher impact on GHG emissions.

\section{Uncertainty of the input parameters and results}

To assess the impact of SCK on GHG emissions many input parameters are needed. Some of the input parameters that were used show large variation in literature, whereas for others limited information is available. Moreover, input parameters were based on studies from different countries, with different farm management, and different milk production levels. This variation and uncertainty in input parameters causes uncertainty of results. Examples of input parameters with large variation are incidence of diseases, and the RRs between SCK and related diseases DA, metritis, and clinical ketosis (Raboisson et al., 2014). The RRs between SCK and related diseases lameness and mastitis, on the other hand, were analysed in a few studies only (Berge and Vertenten, 2014; Suthar et al., 2013). The impact of SCK (and related diseases) on GHG emissions was estimated for one lactation, because there were no data available for the incidence of diseases over multiple lactations. Estimating the impact of diseases over one lactation only, however, is a common method to estimate the economic impact of diseases (Bruijnis et al., 2010; Huijps and Hogeveen, 2007; Inchaisri et al., 2010). Other choices that were made because of data limitations include the assumption that cows with SCK and a related disease were removed at day 30 of lactation, and that cows could get only one related disease after SCK. In practice, cows might also be removed at a later stage because of SCK and get multiple diseases after SCK. Including these aspects will likely increase the impact of SCK on GHG emissions. Finally, literature shows that emissions factors of feed production, enteric methane, and manure contain high levels of uncertainty and variability (IPCC, 2006; Van Middelaar et al., 2013). This also holds for this study. Because using secondary data is common in studies modelling the environmental impact of agricultural systems (Van Middelaar et al., 2014a; Zehetmeier et al., 2014) or economic impact of diseases (Bruijnis et al., 2010; Huijps and Hogeveen, 2007), a sensitivity analysis to address the impact of variation in assumed input parameters is needed.

Results from the sensitivity analysis show that the removal risk of related diseases, the RR of metritis, and the incidence of mastitis had a considerable impact on the results. To improve 
estimations of our model, more detailed information is needed about milk losses, disease incidence, cause of removal, fertility, and the interactions between these factors. Furthermore, emission calculations can be improved by using detailed information on farm management practices, including diet and herd composition. This can also contribute to estimating the impact of SCK on GHG emissions for a specific farm. Current developments in technology and automation can support the collection of farm specific data, including data on disease incidences. Collecting farm specific data on emissions, however, will remain difficult. In case we could measure all relevant farm data, a complete farm LCA could be performed and the impact of SCK on GHG emissions could be analysed over multiple lactations. In all situations, it is important to clearly communicate assumptions when presenting the impact of SCK on GHG emissions.

\section{Assessing the impact of removal}

Most LCA studies use economic allocation (De Vries and de Boer, 2010) to allocate emissions to the different outputs in case of a multiple output system (e.g. milk and meat from a dairy farm). In this study, system expansion was used. This is in line with ISO 14044 (2006) that recommends to avoid allocation by expanding the product system to include the additional functions related to the co-products. In this study, milk production was considered the main purpose of dairy farming and the meat of dairy cows and calves was assumed to substitute beef, pork or chicken. Assumptions regarding the type of meat that is replaced can have an important impact on the result (Van Middelaar et al., 2014a). Moreover, Zehetmeier et al. (2014) showed that the emission factor of the replacing product is one of the most important parameters affecting GHG calculations of milk production. In our study, GHG calculations were based on the average consumption pattern of meat products in OECD countries.

Several economic models have been developed to estimate the economic impact of removal of cows and to estimate the optimal moment of removal (Cabrera, 2012; Groenendaal et al., 2004; Houben et al., 1994). Studies about the costs of diseases estimated the costs of removal by using these models. These type of models, however, do not exist for GHG emissions and could therefore not be used in this study. A second approach is to compute the difference between the opportunity costs of a heifer and the value of meat from the removed cow (Raboisson et al., 2015). In this case, each cow gets the same burden, regardless her parity and the amount of milk produced. A third approach is to depreciate the difference of the opportunity costs of a heifer and the meat value of the removed cow (Getaneh et al., 2017). The latter approach was used in our study. The difference of emissions of GHGs from raising a heifer and the meat value of the removed cow was depreciated over the life time milk production of that cow, to estimate emissions of early removal. Cows that 
were removed before the end of parity 5 , increased the relative contribution of emissions related to replacement. Changing the depreciation time, therefore, will affect the results since removal of cows had a large impact on emissions. Specific models for the environmental impact of removal of cows, such as developed to estimate the economic impact of removal, could improve the estimation of the impact of SCK on GHG emissions.

\section{Reducing subclinical ketosis}

Current incentives to reduce SCK relate to the economic impact of SCK, and to the impact on animal welfare. The importance of SCK to reduce GHG emissions, however, might increase with the upcoming attention for policies (e.g. carbon quota) to reduce GHG emissions from agriculture. Currently, agriculture does not participate in carbon trading, and is not affected by any policy to reduce GHG emissions. With the Paris agreement, however, this might change. Many mitigation options to reduce GHG emissions cost money. Reducing SCK, however, also increases profitability of the farm (McArt et al., 2015; Raboisson et al., 2015) and therefore is an interesting strategy to reduce emissions, while at the same time improving the economic performance of the sector.

Several studies investigated strategies to reduce SCK and to improve the energy balance of the cow. Vickers et al. (2013), for example, showed that using a diet containing $87 \%$ instead of $77 \%$ forage during the dry period decreased SCK incidence after calving from 49\% to $17 \%$. McArt et al. (2011), furthermore, showed that a propylene glycol treatment reduces the risk of SCK to develop in clinical ketosis, and reduces milk losses. In addition, Van Knegsel et al. (2014) showed that shortening the dry period of the cow improves the energy balance after calving. While the latter two strategies have already been shown to have a positive impact on the economic performance of dairy production (Heeren et al., 2014; McArt et al., 2014), no studies have assessed the impact on GHG emissions. Strategies to reduce SCK, however, not only affect various production parameters (e.g. milk production and herd composition), but also other processes that could alter the emission of GHGs per unit of milk production (e.g. feed production, enteric fermentation). Assessing the climate impact of SCK, therefore, can be complicated and can show large variation between farms.

Examples of other mitigation options to reduce GHG emissions in the dairy sector are feeding and breeding strategies. Different feeding strategies can have a higher reduction in GHG emissions (9$32 \mathrm{~kg} \mathrm{CO}_{2} \mathrm{e} / \mathrm{t} \mathrm{FPCM}$ ) (Van Middelaar et al., 2014b) than reducing SCK. These strategies, however, reduce the income of the farmer (Van Middelaar et al., 2014b), whereas reducing SCK will increase the income of the farmer (McArt et al., 2015; Raboisson et al., 2015). Increasing milk yield with $698 \mathrm{~kg} /$ year per cow and longevity with 270 days per cow showed a reduction of 27 and $23 \mathrm{~kg}$ 
$\mathrm{CO}_{2} \mathrm{e} / \mathrm{t}$ FPCM (Van Middelaar et al., 2014a). Achieving this production by breeding, however, will take several years, whereas reducing SCK can be effectuated immediately. The impact of SCK on GHG emissions at herd level depends on the disease incidence of the herd. Complete eradication of SCK might not be achievable, but an incidence of $10 \%$ of SCK at herd level might be (Raboisson et al., 2015). Reducing the incidence of SCK from $25 \%$ to $10 \%$ at herd level will have, on average, a minor impact on GHG emissions. On dairy farms with a high incidence of SCK and related diseases and a higher removal rate of cows, however, reducing SCK and related diseases could be an effective strategy to reduce GHG emissions.

Our study estimated the impact of SCK and related diseases occurring in the first 30 days after calving only. Hospido and Sonesson (2005) showed that reducing subclinical mastitis (from 33\% to $15 \%$ ) and clinical mastitis (from $25 \%$ to $18 \%$ ) occurring during a whole lactation can decrease GHG emissions at herd level by $2.5 \%$. Including more diseases and removal of cows during the whole lactation will increase the impact on GHG emissions and the importance of reducing diseases in dairy cows.

\section{Conclusions}

This study showed that reducing SCK and related diseases in dairy herds can reduce GHG emissions per unit of milk produced. The average increase of GHG emissions per case of SCK was 20.9 (2.3\%) $\mathrm{kg} \mathrm{CO}_{2} \mathrm{e} / \mathrm{t}$ FPCM. Feed production and enteric fermentation were the largest contributors. The increase in GHG emissions was 7.9 (0.9\%) $\mathrm{kg} \mathrm{CO}_{2} \mathrm{e} / \mathrm{t} \mathrm{FPCM}$ per case for cows with SCK only, 31.4 (3.4\%) $\mathrm{kg} \mathrm{CO}_{2} \mathrm{e} / \mathrm{t} \mathrm{FPCM}$ per case for cows with SCK and a related disease that were not removed, 188.2 (20.4\%) $\mathrm{kg} \mathrm{CO}_{2} \mathrm{e} / \mathrm{t} \mathrm{FPCM}$ per case for cows that were culled, and 463.0 (50.2\%) $\mathrm{kg} \mathrm{CO}_{2} \mathrm{e} / \mathrm{t}$ FPCM per case for cows that died on farm. Sensitivity analyses showed that uncertainty of emissions factors and variation of input parameters have a large impact on the results. This study furthermore showed that combining LCA with dynamic stochastic modelling of diseases in dairy cows can contribute to estimating the impact of diseases on GHG emissions of milk production. Other strategies to reduce GHG emissions might be more effective, but preventing SCK also improves farmer income and the welfare of the cow and therefore contributes to improving the overall sustainability of the dairy sector. 


\section{References}

Bannink, A., France, J., Lopez, S., Gerrits, W.J.J., Kebreab, E., Tamminga, S., Dijkstra, J., 2008. Modelling the implications of feeding strategy on rumen fermentation and functioning of the rumen wall. Anim. Feed Sci. Technol. 143, 3-26.

Bannink, A., Smits, M.C.J., Kebreab, E., Mills, J.A.N., Ellis, J.L., Klop, A., France, J., Dijkstra, J., 2010. Simulating the effects of grassland management and grass ensiling on methane emission from lactating cows. J. Agric. Sci. 148, 55-72.

Bar, D., Gröhn, Y.T., Bennett, G., González, R.N., Hertl, J.A., Schulte, H.F., Tauer, L.W., Welcome, F.L., Schukken, Y.H., 2008. Effects of repeated episodes of generic clinical mastitis on mortality and culling in dairy cows. J. Dairy Sci. 91, 2196-2204.

Baumann, H., Tillmann, A., 2004. The hitch hiker's guide to LCA An orientation in life cycle assessment methodology and application. Studentlitteratur AB, Lund, Sweden, 543.

Berge, A.C., Vertenten, G., 2014. A field study to determine the prevalence, dairy herd management systems, and fresh cow clinical conditions associated with ketosis in western European dairy herds. J. Dairy Sci. 97, 2145-2154.

Bruijnis, M.R.N., Hogeveen, H., Stassen, E.N., 2010. Assessing economic consequences of foot disorders in dairy cattle using a dynamic stochastic simulation model. J. Dairy Sci. 93, 2419-2432.

Cabrera, V.E., 2012. A simple formulation and solution to the replacement problem: A practical tool to assess the economic cow value, the value of a new pregnancy, and the cost of a pregnancy loss. J. Dairy Sci. 95, 4683-4698.

CBS 2014. Dierlijke mest en mineralen 2013 (Animal manure and minerals 2013). Centraal Bureau voor de Statistiek, Den Haag, the Netherlands.

Cederberg, C., Mattsson, B., 2000. Life cycle assessment of milk production - a comparison of conventional and organic farming. J Clean Prod. 8, 49-6o.

CRV 2014. Jaarstatistieken 2014 voor Nederland (Annual statistics 2014). CRV, Arnhem, the Netherlands.

CVB 2012. Tabellenboek veevoeding 2012, voedernormen landbouwhuisdieren en voederwaarde veevoeders (Composition and nutritional values of feedstuffs and requirement values), CVB-reeks nr.5o, August 2012. Productschap Diervoeder, Den Haag, the Netherlands.

De Mol, R.M., Hilhorst, M.A., 2003. Emissions of methane, nitrous oxide and ammonia from production, storage and transport of manure. Institute of Agricultural and Environmental Engineering, Wageningen, the Netherlands.

De Vries, J.W., Hoeksma, P., Groenestein, C.M., 2011. LevensCyclusAnalyse (LCA) pilot mineralenconcentraten. Wageningen UR Livestock Research, Wageningen, the Netherlands.

De Vries, M., de Boer, I.J.M., 2010. Comparing environmental impacts for livestock products: A review of life cycle assessments. Livest. Sci 128, 1-11. 
Dijkhuizen, A.A., Jalvingh, A.W., Huirne, R.B.M., 1997. Critical steps in systems simulation, In: A.A. Dijkhuizen and R.S. Morris (Eds), Animal health economics: principles and applications, Post graduate foundation in Veterinary Science, University of Sydney, Sydney South, Australia, pp. 59-68.

Duffield, T.F., Lissemore, K.D., McBride, B.W., Leslie, K.E., 2009. Impact of hyperketonemia in early lactation dairy cows on health and production. J. Dairy Sci. 92, 571-580.

FAO, 2011. World Livestock 2011 - Livestock in food security. Food and Agriculture Organization of the United Nations (FAO), Rome.

Fourichon, C., Seegers, H., Malher, X., 2000. Effect of disease on reproduction in the dairy cow: a meta-analysis. Theriogenology 53, 1729-1759.

Gerber, P.J., Steinfeld, H., Henderson, B., Mottet, A., Opio, C., Dijkman, J., Falcucci, A., Tempio, G., 2013. Tackling climate change through livestock - A global assessment of emissions and mitigation opportunities. Food and Agriculture Organization of the United Nations (FAO), Rome.

Getaneh, A.M., Mekonnen, S.A., Hogeveen, H., 2017. Stochastic bio-economic modeling of mastitis in Ethiopian dairy farms. Prev. Vet. Med. 138, 94-103.

Giuliodori, M.J., Magnasco, R.P., Becu-Villalobos, D., Lacau-Mengido, I.M., Risco, C.A., de la Sota, R.L., 2013. Metritis in dairy cows: Risk factors and reproductive performance. J. Dairy Sci. 96, 3621-3631.

Groenendaal, H., Galligan, D.T., Mulder, H.A., 2004. An economic spreadsheet model to determine optimal breeding and replacement decisions for dairy cattle. J. Dairy Sci. 87, 2146-2157.

Gröhn, Y.T., Rajala-Schultz, P.J., Allore, H.G., DeLorenzo, M.A., Hertl, J.A., Galligan, D.T., 2003. Optimizing replacement of dairy cows: Modeling the effects of diseases. Prev. Vet. Med. 61, 27-43.

Grummer, R.R., 1995. Impact of changes in organic nutrient metabolism on feeding the transition dairy cow. J. Anim. Sci. 73, 2820-33.

Guinée, J., Gorrée, M., Heijungs, R., Huppes, G., Kleijn, R., de Koning, A., van Oers, L., Wegener Sleeswijk, A., Suh, S., Udo de Haes, H., de Bruijn, H., van Duin, R., Huijbregts, M., Lindeijer, E., Roorda, A., van der Ven, B., Weidema, B., 2002. Handbook on life cycle assessment. Operational guide to the ISO standards. Kluwer, Leiden, The Netherlands.

Heeren, J.A.H., Steeneveld, W., Berentsen, P.B.M., 2014. Economic comparison of a sixty day dry period with no dry period on Dutch dairy farms. Livest. Sci. 168, 149-158.

Hospido, A., Sonesson, U., 2005. The environmental impact of mastitis: a case study of dairy herds. Sci. Total Environ. 343, 71-82.

Houben, E.H., Huirne, R.B., Dijkhuizen, A.A., Kristensen, A.R., 1994. Optimal replacement of mastitic cows determined by a hierarchic Markov process. J. Dairy Sci. 77, 2975-2993.

Huijps, K., Hogeveen, H., 2007. Stochastic modeling to determine the economic effects of blanket, selective, and no dry cow therapy. J. Dairy Sci. 90, 1225-1234. 
Inchaisri, C., Jorritsma, R., Vos, P.L.A.M., van der Weijden, G.C., Hogeveen, H., 2010. Economic consequences of reproductive performance in dairy cattle. Theriogenology 74, 835-846.

IPCC, 2006. Intergovernmental Panel on Climate Change. Guidelines for national greenhouse gas inventories, in: H.S. Eggleston, L. Buendia, K. Miwa, T. Ngara, K. Tanabe (Eds.), Agriculture, Forestry and Other Land Use, vol. 4, IGES, Japan (2006).

ISO 14044, 2006. Environmental management - Life cycle assessment- Requirements and guidelines. European Committee for Standardization (CEN), Brussels, Belgium.

Jorritsma, R., Westerlaan, B., Bierma, M.P.R., Frankena, K., 2008. Milk yield and survival of Holstein-Friesian dairy cattle after laparoscopic correction of left-displaced abomasum. Vet. Rec. 162, 743-746.

LeBlanc, S.J., Leslie, K.E., Duffield, T.F., 2005. Metabolic predictors of displaced abomasum in dairy cattle. J. Dairy Sci. 88, 159-170.

McArt, J.A.A., Nydam, D.V., Oetzel, G.R., 2012. Epidemiology of subclinical ketosis in early lactation dairy cattle. J. Dairy Sci. 95, 5056-5066.

McArt, J.A.A., Nydam, D.V., Oetzel, G.R., Guard, C.L., 2014. An economic analysis of hyperketonemia testing and propylene glycol treatment strategies in early lactation dairy cattle. Prev. Vet. Med. 117, 170-179.

McArt, J.A.A., Nydam, D.V., Ospina, P.A., Oetzel, G.R., 2011. A field trial on the effect of propylene glycol on milk yield and resolution of ketosis in fresh cows diagnosed with subclinical ketosis. J. Dairy Sci. 94, 6011-6020.

McArt, J.A.A., Nydam, D.V., Overton, M.W., 2015. Hyperketonemia in early lactation dairy cattle: A deterministic estimate of component and total cost per case. J. Dairy Sci. 98, 2043-2054.

Myhre, G., Shindell, D., Bréon, F.-M., Collins, W., Fuglestvedt, J., J. Huang, D.K., Lamarque, J.F., Lee, D., Mendoza, B., Nakajima, T., Robock, A., Stephens, G., Takemura, T., H. Zhang, 2013. Anthropogenic and Natural Radiative Forcing, In: Stocker, T.F., D. Qin, G.-K. Plattner, M. Tignor, S.K. Allen, J. Boschung, A. Nauels, Y. Xia, V. Bex and P.M. Midgley (eds.), Climate Change 2013: The Physical Science Basis. Contribution of Working Group I to the Fifth Assessment Report of the Intergovernmental Panel on Climate Change. Cambridge University Press, Cambridge, United Kingdom and New York, NY, USA.

OECD, 2015. Meat consumption (indicator). doi: 10.1787/fa29ofdo-en (Accessed on 18.05.15).

Olivier, J.G.J., Brandes, L.J., te Molder, R.A.B., 2009. Uncertainty in the Netherlands' greenhouse gas emissions inventory Estimation of the level and trend uncertainty using the IPCC Tier 1 approach. Netherlands Environmental Assessment Agency (PBL), Den Haag, the Netherlands.

Overton, M., Fetrow, J., 2008. Economics of postpartum uterine health. In Proceedings of the 2008 Dairy Cattle Reproduction Council Convention, 7-8 November 2008, Omaha, NE, USA, pp. 39-43.

R_Core_Team, 2016. R: A language and environment for statistical computing. R Foundation for Statistical Computing, Vienna, Austria. 
Raboisson, D., Mounié, M., Khenifar, E., Maigné, E., 2015. The economic impact of subclinical ketosis at the farm level: Tackling the challenge of over-estimation due to multiple interactions. Prev. Vet. Med. 122, 417-425.

Raboisson, D., Mounié, M., Maigné, E., 2014. Diseases, reproductive performance, and changes in milk production associated with subclinical ketosis in dairy cows: A meta-analysis and review. J. Dairy Sci. 97, 7547-7563.

Raizman, E.A., Santos, J.E.P., Thurmond, M.C., 2002. The effect of left displacement of abomasum corrected by toggle-pin suture on lactation, reproduction, and health of Holstein dairy cows. J. Dairy Sci. 85, 1157-1164.

Rajala, P.J., Gröhn, Y.T., 1998. Effects of dystocia, retained placenta, and metritis on milk yield in dairy cows. J. Dairy Sci. 81, 3172-3181.

Remmelink, G., Van Middelkoop, J., Ouweltjes, W., Wemmenhove, H., 2014. Handboek melkveehouderij. Wageningen UR Livestock Research, Wageningen, the Netherlands.

Santos, J.E.P., Cerri, R.L.A., Ballou, M.A., Higginbotham, G.E., Kirk, J.H., 2004. Effect of timing of first clinical mastitis occurrence on lactational and reproductive performance of Holstein dairy cows. Anim. Reprod. Sci. 80, 31-45.

Seegers, H., Fourichon, C., Beaudeau, F., 2003. Production effects related to mastitis and mastitis economics in dairy cattle herds. Vet. Res. 34, 475-491.

Suthar, V.S., Canelas-Raposo, J., Deniz, A., Heuwieser, W., 2013. Prevalence of subclinical ketosis and relationships with postpartum diseases in European dairy cows. J. Dairy Sci. 96, 29252938.

Thomassen, M.A., Dalgaard, R., Heijungs, R., de Boer, I., 2008. Attributional and consequential LCA of milk production. Int. J. Life Cycle Assess. 13, 339-349.

Van Knegsel, A.T.M., Remmelink, G.J., Jorjong, S., Fievez, V., Kemp, B., 2014. Effect of dry period length and dietary energy source on energy balance, milk yield, and milk composition of dairy cows. J. Dairy Sci. 97, 1499-1512.

Van Middelaar, C.E., Berentsen, P.B.M., Dijkstra, J., van Arendonk, J.A.M., de Boer, I.J.M., 2014a. Methods to determine the relative value of genetic traits in dairy cows to reduce greenhouse gas emissions along the chain. J. Dairy Sci. 97, 5191-5205.

Van Middelaar, C.E., Cederberg, C., Vellinga, T.V., Van Der Werf, H.M.G., De Boer, I.J.M., 2013. Exploring variability in methods and data sensitivity in carbon footprints of feed ingredients. Int. J. Life Cycle Assess. 18, 768-782.

Van Middelaar, C.E., Dijkstra, J., Berentsen, P.B.M., De Boer, I.J.M., 2014b. Cost-effectiveness of feeding strategies to reduce greenhouse gas emissions from dairy farming. J. Dairy Sci. 97, 2427-2439.

Vellinga T.V., Blonk H., Marinussen M., Van Zeist W.J., De Boer I.J.M., 2013. Methodology used in feedprint: a tool quantifying greenhouse gas emissions of feed production and utilization. Wageningen UR Livestock research, Lelystad, the Netherlands. 
38 | Chapter 2

Velthof, G.L., Mosquera, J., 2011. Calculation of nitrous oxide emission from agriculture in the Netherlands. Alterra, Wageningen, the Netherlands.

Vickers, L.A., Weary, D.M., Veira, D.M., von Keyserlingk, M.A.G., 2013. Feeding a higher forage diet prepartum decreases incidences of subclinical ketosis in transition dairy cows. J. Anim. Sci. 91, 886-894.

Vonk, J., Bannink, A., van Bruggen, C., Groenestein, C.M., Huijsmans, J.F.M., van der Kolk, J.W.H., Luesink, H.H., Oude Voshaar, S.V., van der Sluis, S.M., Velthof, G.L., 2016. Methodology for estimating emissions from agriculture in the Netherlands Calculations of $\mathrm{CH}_{4}, \mathrm{NH}_{3}, \mathrm{~N} 2 \mathrm{O}, \mathrm{NOx}, \mathrm{PM} 10, \mathrm{PM} 2.5$ and $\mathrm{CO}_{2}$ with the National Emission Model for Agriculture (NEMA). The Statutory Research Tasks Unit for Nature and the Environment (WOT Natuur \& Milieu), Wageningen, the Netherlands.

Walsh, R.B., Walton, J.S., Kelton, D.F., LeBlanc, S.J., Leslie, K.E., Duffield, T.F., 2007. The effect of subclinical ketosis in early lactation on reproductive performance of postpartum dairy cows. J. Dairy Sci. 90, 2788-2796.

Wilson, D.J., González, R.N., Hertl, J., Schulte, H.F., Bennett, G.J., Schukken, Y.H., Gröhn, Y.T., 2004. Effect of clinical mastitis on the lactation curve: A mixed model estimation using daily milk weights. J. Dairy Sci. 87, 2073-2084.

Wood, P.D.P., 1967. Algebraic model of the lactation curve in cattle. Nature 216, 164-165.

Zehetmeier, M., Gandorfer, M., Hoffmann, H., Müller, U.K., De Boer, I.J.M., Heißenhuber, A., 2014. The impact of uncertainties on predicted greenhouse gas emissions of dairy cow production systems. J Clean Prod. 73, 116-124. 


\section{Supplementary material}

\section{Appendix A}

\section{Cow characteristics (part 1)}

Milk production (305 days) $\left(\mathrm{M}_{\mathrm{i}}\right)$ per parity is determined with a normal distribution function

$\mathrm{M}_{\mathrm{i}}=\operatorname{Normal}\left(\mathrm{MEAN}_{\mathrm{mi}}, \mathrm{SD}_{\mathrm{mi}}\right)$

Where

MEAN $_{m i}=$ mean milk production (M) in 305 days of cow $\mathrm{i}$,

$\mathrm{SD}_{\mathrm{mi}}=$ standard deviation of milk production of cow $\mathrm{i}$, which was $5.9 \%$ of the mean based on Bruijnis et al. (2010).

\section{Dynamic of SCK and related diseases (part 2)}

In the model, SCK and the diseases mastitis, metritis, displaced abomasum, lameness and clinical ketosis occurring in the first 30 days after calving are included. First, cows have a probability $\left(\right.$ Psck $_{\mathrm{i}}$ ) based on their parity to get subclinical ketosis (SCK $)$, and had SCK (1) or not (o).

$\operatorname{SCK}_{\mathrm{i}}=\operatorname{discrete}\left(\{1,0\} ;\left\{\right.\right.$ Psck $_{\mathrm{i}}, 1-$ Psck $\left.\left._{\mathrm{i}}\right\}\right)$

Second, cows with SCK had an additional probability on a related disease.

Cows had an additional probability based on their parity to get one of the following diseases (o): clinical ketosis (CK), mastitis (MAS), metritis (MET), displaced abomasum (DA), lameness (LAM), no extra disease (SCKONLY) (Berge and Vertenten, 2014).

SCKDISEASE $_{\mathrm{i}}=$ discrete (\{SCKONLY, SCKMAS, SCKMET, SCKDA, SCKLAM, SCKCK $\}$; $\left\{\right.$ Psckonly $_{\mathrm{i}}$, Psckmas $_{\mathrm{i}}$, Psckmet $_{\mathrm{i}}$, Psckda $_{\mathrm{i}}$, Pscklam $_{\mathrm{i}}$, Psckck $\left._{\mathrm{i}}\right\}$ )

(Eq. (A.3))

Third, cows with SCK could be removed $\left(\mathrm{SCKrem}_{\mathrm{i}}\right)$. Cows have a probability to get culled (Pcul) or death (Pdeath) or not culled or death (Plife). The probability of each is dependent on parity of the cow and SCKDISEASE.

SCKrem $_{\mathrm{i}}=$ discrete $\left(\{\mathrm{CUL}\right.$, DEATH, LIFE $\},\left\{\right.$ Pcul $_{\mathrm{i}}$, Pdeath $\left.\left._{\mathrm{i}}, \mathrm{Plife}_{\mathrm{i}}\right\}\right)$

(Eq. (A.4))

Where 
40 | Chapter 2

Pcul $_{i}=$ probability of cow (i) to get culled

Pdeath $_{\mathrm{i}}=$ probability of cow (i) to get death

Plife $_{\mathrm{i}}=1-\mathrm{Pcul}_{\mathrm{io}}-\mathrm{Pdeath}_{\mathrm{io}}$

\section{Losses due to diseases (part 3)}

All cows with SCK had the same percentage of reduced milk production at day 1-30. Cows with a related disease after SCK also had after day 30 a reduced milk production for a period which was diseases specific. Total milk losses because of reduced milk production (ML) were summed.

$\mathrm{ML}_{\mathrm{i}}=\mathrm{M}_{\mathrm{id}} \mathrm{x} \operatorname{MLTP}+\mathrm{M}_{\mathrm{id}} \mathrm{x} \mathrm{MLO}_{\mathrm{id}}$

Where

$\mathrm{M}_{\mathrm{id}}=$ milk production of cow (i) on day (d)

MLTP $=\%$ milk production losses of cow (i) with SCK per day on day 1-30

$\mathrm{MLO}_{\mathrm{id}}=\%$ milk production losses of cow (i) with related disease per day (d) after day 30

Cows with a related disease after SCK were treated and the milk during these days was discarded. Milk discarded (Mmd) were summed to estimate the total.

$\mathrm{Mmd}_{\mathrm{i}}=\mathrm{M}_{\mathrm{id}} \mathrm{x}(1-\mathrm{MLTP}) \times$ Dwith $_{\mathrm{d}}$

Where

Dwith $_{d}=$ the withdrawal of milk due to treatment of disease at day $(d)(1,0)$

Milk production losses due to removal were estimated as the difference between the milk production of the cow without SCK, and the milk production of the removed cow during the first 30 days and the new heifer.

\subsection{Estimation of GHG emissions (part 4)}

Fat-and-protein-corrected milk (FPCM) was estimated per day.

$\mathrm{FPCM}_{\mathrm{id}}=(0.337+0.116 \mathrm{x} \% \mathrm{~F}+0.06 \mathrm{x} \% \mathrm{P}) \times \mathrm{M}_{\mathrm{id}}$

Where

$\% \mathrm{~F}(4.36)$ is fat percentage in milk (CRV, 2014)

\% $\mathrm{P}(3.54)$ is protein percentage in milk $(\mathrm{CRV}, 2014)$

Energy requirement for maintenance and milk production of the cow was estimated per day as voeder eenheid melk (VEM), whereas 1,00o VEM was equivalent to $6.9 \mathrm{MJ}$ of net energy. 


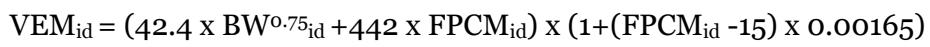

where

$\mathrm{BW}^{0.75_{\text {id }}}=$ Body weight of cow (i) at day (d)

$\mathrm{FPCM}_{\mathrm{id}}=$ Fat-and-protein-corrected milk of cow (i) at day (d)

Cows received additional VEM for pregnancy (450, 850, 1500, 2700 during last four months of pregnancy) and parity 1 (660 per day) and parity 2 (330 per day) cows received additional VEM for growth (CVB, 2012). Body weight increased linear per week in parity 1 and 2. 
42 | Chapter 2

\section{Appendix B}

Table B.1 Dietary composition and energy content of feed ingredients.

\begin{tabular}{llll}
\hline Feed ingredient & $\begin{array}{l}\mathrm{NE}^{\mathrm{a}} \\
(\mathrm{MJ} / \mathrm{kg} \mathrm{DM})\end{array}$ & $\begin{array}{l}\text { Summer diet }^{\mathrm{b}} \\
(\% / \mathrm{kg} \mathrm{DM})\end{array}$ & $\begin{array}{l}\text { Winter diet }^{\mathrm{b}} \\
(\% / \mathrm{kg} \mathrm{DM})\end{array}$ \\
\hline Concentrates standard $^{\mathrm{c}}$ & 7.43 & 21 & 20 \\
Concentrates protein $^{\mathrm{c}}$ & 7.45 & 0 & 7 \\
Wet by products $^{\mathrm{d}}$ & 7.50 & 4 & 5 \\
Grass & 6.95 & 39 & 0 \\
Grass silage & 6.08 & 25 & 55 \\
Maize silage & 6.26 & 11 & 14 \\
\hline
\end{tabular}

a Vellinga et al., 2013

${ }^{\mathrm{b}} \mathrm{CBS}, 2014$

' Nevedi, 2012, 2013, 2014, 2015

d Wet by products consisted of (\%/kg DM): 29\% brewer's grain dried, $32 \%$ potato peel steamed, $16 \%$ potato pulp dried, $23 \%$ maize gluten meal

Table B.2 Greenhouse gas emissions of feed production and land use and land use change (LULuc), enteric methane emissions, and nitrogen content of feed ingredients.

\begin{tabular}{|c|c|c|c|c|}
\hline Feed ingredient & $\begin{array}{l}\text { Feed production }^{\mathrm{a}} \\
\left(\mathrm{g} \mathrm{CO}_{2} \mathrm{e} / \mathrm{kg} \mathrm{DM}\right)\end{array}$ & $\begin{array}{l}\text { LULuc }^{\mathrm{a}} \\
\left(\mathrm{g} \mathrm{CO}_{2} \mathrm{e} / \mathrm{kg} \mathrm{DM}\right)\end{array}$ & $\begin{array}{l}\text { Enteric methane }^{\mathrm{a}} \\
\text { (g CH} \mathrm{CH}_{4} / \mathrm{kg} \mathrm{DM} \text { ) }\end{array}$ & $\begin{array}{l}\mathrm{N}^{\mathrm{a}} \\
\text { (g/kg DM) }\end{array}$ \\
\hline Concentrates standard ${ }^{b}$ & 762 & 142 & 23.1 & 26.1 \\
\hline Concentrates protein ${ }^{b}$ & 664 & 142 & 22.7 & 31.4 \\
\hline Wet by products ${ }^{c}$ & 388 & 20 & 19.2 & 46.5 \\
\hline Grass silage & 426 & 78 & 20.1 & 28.3 \\
\hline Maize silage & 148 & 92 & 17.7 & 12.6 \\
\hline
\end{tabular}

a Vellinga et al., 2013

b Nevedi, 2012, 2013, 2014, 2015

c Wet by products consisted of (\%/kg DM): $29 \%$ brewer's grain dried, $32 \%$ potato peel steamed, $16 \%$ potato pulp dried, 23\% maize gluten meal 
Table B.3 Composition of concentrates for dairy cows, and dry matter content per ingredient, and GHG emissions of feed production, land use and land use change (LULuc), and enteric methane per ingredient and per composition.

\begin{tabular}{|c|c|c|c|c|c|c|}
\hline Feed ingredient & $\begin{array}{l}\text { Standard }^{a} \\
(\% / \mathrm{kg})\end{array}$ & $\begin{array}{l}\text { Protein }^{a} \\
(\% / k g)\end{array}$ & $\begin{array}{l}\text { Feed } \\
\text { production } \\
\left(\mathrm{g} \mathrm{CO}_{2} \mathrm{e} / \mathrm{kg}\right)\end{array}$ & $\begin{array}{l}\text { LULuc }^{\mathrm{b}} \\
\left(\mathrm{g} \mathrm{CO}_{2} \mathrm{e} / \mathrm{kg}\right)\end{array}$ & $\begin{array}{l}\text { Enteric } \\
\text { methane }^{\mathrm{b}} \\
\left(\mathrm{g} \mathrm{CH}_{4} / \mathrm{kg}\right)\end{array}$ & $\begin{array}{l}\text { Dry Matter } \\
\text { (g/kg) }\end{array}$ \\
\hline Peas & 0.00 & 1.20 & 578 & 744 & 21.97 & 867 \\
\hline Barley & 0.35 & 0.15 & 219 & 166 & 22.17 & 869 \\
\hline Soya (bean) meal Mervobest & 0.00 & 0.15 & 475 & 414 & 19.21 & 872 \\
\hline Soybean hulls CF' $320-360$ & 14.52 & 19.47 & 306 & 222 & 22.94 & 883 \\
\hline Sugarcane molasses SUG' $<475$ & 3.01 & 3.17 & 265 & 27 & 28.58 & 734 \\
\hline Rape seed, expeller & 0.17 & 0.99 & 270 & 184 & 17.36 & 894 \\
\hline Rye & 5.15 & 1.10 & 274 & 237 & 23.27 & 872 \\
\hline Wheat & 2.05 & 2.17 & 216 & 147 & 22.9 & 868 \\
\hline Palm kernel expeller $\mathrm{CF}<180$ & 11.80 & 15.95 & 417 & 30 & 17.07 & 961 \\
\hline Sugarbeet pulp SUG>200 & 3.80 & 4.70 & 366 & 0 & 25.76 & 915 \\
\hline Maize & 15.87 & 6.57 & 390 & 167 & 20.09 & 872 \\
\hline Soybean meal CF45-70 $\mathrm{CP}^{\mathrm{c}}<450$ & 0.14 & 2.95 & 463 & 401 & 20.27 & 876 \\
\hline Wheat middlings & 11.32 & 2.07 & 158 & 77 & 20.34 & 865 \\
\hline Palm kernel oil & 0.21 & 0.42 & 2606 & 301 & 0 & 995 \\
\hline Maize glutenfeed CP200-230 & 8.60 & 1.65 & 1632 & 186 & 19.78 & 893 \\
\hline Sunflower seed meal CF>240 & 0.67 & 1.00 & 375 & 410 & 16.97 & 887 \\
\hline Salt & 0.46 & 0.56 & 180 & 0 & 0 & 998 \\
\hline Chalk (finely milled) & 0.99 & 1.28 & 18.5 & 0 & 0 & 990 \\
\hline Triticale & 5.45 & 6.03 & 305 & 254 & 23.2 & 877 \\
\hline Rape seed, extruded $C P>380$ & 0.18 & 0.47 & 253 & 163 & 18.79 & 906 \\
\hline Rape seed, extruded CP 0-380 & 1.78 & 5.38 & 251 & 161 & 18.69 & 873 \\
\hline Rape seed meal Mervobest & 0.00 & 0.15 & 258 & 168 & 17.51 & 872 \\
\hline Soybean meal CF45-70 CP>450 & 0.09 & 0.48 & 478 & 418 & 20.27 & 875 \\
\hline Premix Dairy 31 & 1.00 & 1.00 & 4999 & 0 & 0 & 1000 \\
\hline Vinasses Sugarbeet $C P<250$ & 2.99 & 3.00 & 393 & 0 & 21.69 & 663 \\
\hline Magnesiumoxide & 0.04 & 0.01 & 1060 & 0 & 0 & 1000 \\
\hline Distillers grains and solubles & 9.36 & 17.93 & 295 & 0 & 19.51 & 901 \\
\hline \multicolumn{7}{|l|}{ GHG emissions } \\
\hline Ingredients ( $\mathrm{g} \mathrm{CO}_{2} \mathrm{e} / \mathrm{kg} \mathrm{DM}$ ) & 669 & 571 & & & & \\
\hline Transport to farm ( $\left.\mathrm{g} \mathrm{CO}_{2} \mathrm{e} / \mathrm{kg} \mathrm{DM}\right)$ & 11 & 11 & & & & \\
\hline Feedmill ( $\left.\mathrm{g} \mathrm{CO}_{2} \mathrm{e} / \mathrm{kg} \mathrm{DM}\right)$ & 82 & 81 & & & & \\
\hline Total feed production ( $\mathrm{g} \mathrm{CO}_{2} \mathrm{e} / \mathrm{kg} \mathrm{DM}$ ) & 762 & 664 & & & & \\
\hline LULuc (g CO $2 \mathrm{e} / \mathrm{kg} \mathrm{DM}$ ) & 142 & 142 & & & & \\
\hline Enteric methane ( $\left.\mathrm{g} \mathrm{CH}_{4} / \mathrm{kg} \mathrm{DM}\right)$ & 23.1 & 22.7 & & & & \\
\hline
\end{tabular}

a Nevedi, 2012, 2013, 2014, 2015

bVellinga et al., 2013

${ }^{\mathrm{c}} \mathrm{CF}=$ Crude fiber, $\mathrm{CP}=$ crude protein, $\mathrm{SUG}=$ sugar in $(\mathrm{g} / \mathrm{kg})$ 
44 | Chapter 2

\section{Appendix C}

Table C.1 Emissions factors for $\mathrm{CH}_{4}$ and $\mathrm{N}_{2} \mathrm{O}$ emissions, $\mathrm{NO}_{3}-\mathrm{N}$ leaching and $\mathrm{NH}_{3}-\mathrm{N}+\mathrm{NO}-\mathrm{N}$ volatizing of manure in stable and manure from grazing.

\begin{tabular}{|c|c|c|c|}
\hline \multicolumn{4}{|l|}{ Stable/storage } \\
\hline $\mathrm{N}_{2} \mathrm{O}-\mathrm{N}$ direct & $\mathrm{kg} / \mathrm{kg} \operatorname{TAN}^{\mathrm{a}}$ & 0.0015 & De Vries et al. (2011) \\
\hline $\mathrm{NH}_{3}-\mathrm{N}$ & $\mathrm{kg} / \mathrm{kg}$ TAN & 0.1000 & De Vries et al. (2011) \\
\hline $\mathrm{NO}_{x}-\mathrm{N}$ & $\mathrm{kg} / \mathrm{kg}$ TAN & 0.0015 & De Vries et al. (2011) \\
\hline $\mathrm{CH}_{4}$ & $\mathrm{~kg} /$ ton manure & 0.746 & De Mol and Hilhorst (2003) \\
\hline \multicolumn{4}{|l|}{ Grazing } \\
\hline $\mathrm{N}_{2} \mathrm{O}-\mathrm{N}$ direct & $\mathrm{kg} / \mathrm{kg} \mathrm{N}$ & 0.033 & Vonk et al. (2016) \\
\hline NOx-N & $\mathrm{kg} / \mathrm{kg} \mathrm{N}$ & 0.012 & Vonk et al. (2016) \\
\hline $\mathrm{NH}_{3}-\mathrm{N}^{\mathrm{b}}$ & $\mathrm{kg} / \mathrm{kg}$ TAN & 0.053 & Vonk et al. (2016) \\
\hline $\mathrm{NO}_{3}-\mathrm{N}$ leach & $\mathrm{kg} / \mathrm{kg} \mathrm{N}$ & 0.12 & Velthof and Mosquera (2011) \\
\hline $\mathrm{CH}_{4}$ & $\mathrm{~kg} / \mathrm{m}^{3}$ manure & 0.11 & De Mol and Hilhorst (2003) \\
\hline \multicolumn{4}{|l|}{ All } \\
\hline \multirow[t]{2}{*}{$\mathrm{N}_{2} \mathrm{O}-\mathrm{N}$ indirect } & $\mathrm{kg} / \mathrm{kg} \mathrm{NH}_{3}-\mathrm{N}+\mathrm{NO}_{x}-\mathrm{N}$ & 0.01 & IPCC (2006) \\
\hline & $\mathrm{kg} / \mathrm{kg} \mathrm{NO}{ }_{3}-\mathrm{N}$ & 0.0075 & IPCC (2006) \\
\hline
\end{tabular}

a TAN $=$ Total Ammoniacal Nitrogen

${ }^{\mathrm{b}} \mathrm{EF} \mathrm{NH}_{3}$ grazing $=1.98 \times 10^{-5} \times(\text { Ncontentdiet })^{3.664}$ 


\section{References}

Berge, A.C., Vertenten, G., 2014. A field study to determine the prevalence, dairy herd management systems, and fresh cow clinical conditions associated with ketosis in western European dairy herds. J. Dairy Sci. 97, 2145-2154.

Bruijnis, M.R.N., Hogeveen, H., Stassen, E.N., 2010. Assessing economic consequences of foot disorders in dairy cattle using a dynamic stochastic simulation model. J. Dairy Sci. 93, 2419-2432.

CBS 2014. Dierlijke mest en mineralen 2013 (Animal manure and minerals 2013). Centraal Bureau voor de Statistiek, Den Haag, the Netherlands.

CRV 2014. Jaarstatistieken 2014 voor Nederland (Annual statistics 2014). CRV, Arnhem, the Netherlands.

CVB 2012. Tabellenboek veevoeding 2012, voedernormen landbouwhuisdieren en voederwaarde veevoeders (Composition and nutritional values of feedstuffs and requirement values), CVB-reeks nr.5o, August 2012. Productschap Diervoeder, Den Haag, the Netherlands.

De Mol, R.M., Hilhorst, M.A., 2003. Emissions of methane, nitrous oxide and ammonia from production, storage and transport of manure. Institute of Agricultural and Environmental Engineering, Wageningen, the Netherlands.

De Vries, J.W., Hoeksma, P., Groenestein, C.M., 2011. LevensCyclusAnalyse (LCA) pilot mineralenconcentraten. Wageningen UR Livestock Research, Wageningen, the Netherlands.

IPCC, 2006. Intergovernmental Panel on Climate Change. Guidelines for national greenhouse gas inventories, in: H.S. Eggleston, L. Buendia, K. Miwa, T. Ngara, K. Tanabe (Eds.), Agriculture, Forestry and Other Land Use, vol. 4, IGES, Japan (2006)

Nevedi, 2012. De Nederlandse Vereniging Diervoederindustrie, lineaire programmeringen rundvee-, varkens en pluimveevoerders (The Dutch Feed Industry Association, linear programming cattle-, pig, and poultry feed). Schothorst Feed Research B.V, Report Nr 512, 2012.

Nevedi, 2013. De Nederlandse Vereniging Diervoederindustrie, lineaire programmeringen rundvee-, varkens en pluimveevoerders (The Dutch Feed Industry Association, linear programming cattle-, pig, and poultry feed). Schothorst Feed Research B.V, Report Nr 1 $\mathrm{t} / \mathrm{m} \mathrm{12,} 2013$.

Nevedi, 2014. De Nederlandse Vereniging Diervoederindustrie, lineaire programmeringen rundvee-, varkens en pluimveevoerders (The Dutch Feed Industry Association, linear programming cattle-, pig, and poultry feed). Schothorst Feed Research B.V, Report Nr 1 $\mathrm{t} / \mathrm{m} \mathrm{12,} 2014$.

Nevedi, 2015. De Nederlandse Vereniging Diervoederindustrie, lineaire programmeringen rundvee-, varkens en pluimveevoerders (The Dutch Feed Industry Association, linear 
46 | Chapter 2

programming cattle-, pig, and poultry feed). Schothorst Feed Research B.V, Report Nr 1 $\mathrm{t} / \mathrm{m}$ 5, 2015 .

Vellinga T.V., Blonk H., Marinussen M., Van Zeist W.J., De Boer I.J.M., 2013. Methodology used in feedprint: a tool quantifying greenhouse gas emissions of feed production and utilization. Wageningen UR Livestock research, Lelystad, the Netherlands.

Velthof, G.L., Mosquera, J., 2011. Calculation of nitrous oxide emission from agriculture in the Netherlands. Alterra, Wageningen, the Netherlands.

Vonk, J., Bannink, A., van Bruggen, C., Groenestein, C.M., Huijsmans, J.F.M., van der Kolk, J.W.H., Luesink, H.H., Oude Voshaar, S.V., van der Sluis, S.M., Velthof, G.L., 2016. Methodology for estimating emissions from agriculture in the Netherlands Calculations of $\mathrm{CH}_{4}, \mathrm{NH}_{3}, \mathrm{~N} 2 \mathrm{O}, \mathrm{NOx}, \mathrm{PM} 10, \mathrm{PM} 2.5$ and $\mathrm{CO}_{2}$ with the National Emission Model for Agriculture (NEMA). The Statutory Research Tasks Unit for Nature and the Environment (WOT Natuur \& Milieu), Wageningen, the Netherlands. 


\section{Chapter 3}

The impact of clinical mastitis in dairy cows on greenhouse gas emissions of milk production

P.F. Mostert, E.A.M. Bokkers, I.J.M. de Boer, and C.E. van Middelaar.

Animal Production Systems group, Wageningen University \& Research, PO Box 338, 6700 AH

Wageningen, the Netherlands

Submitted

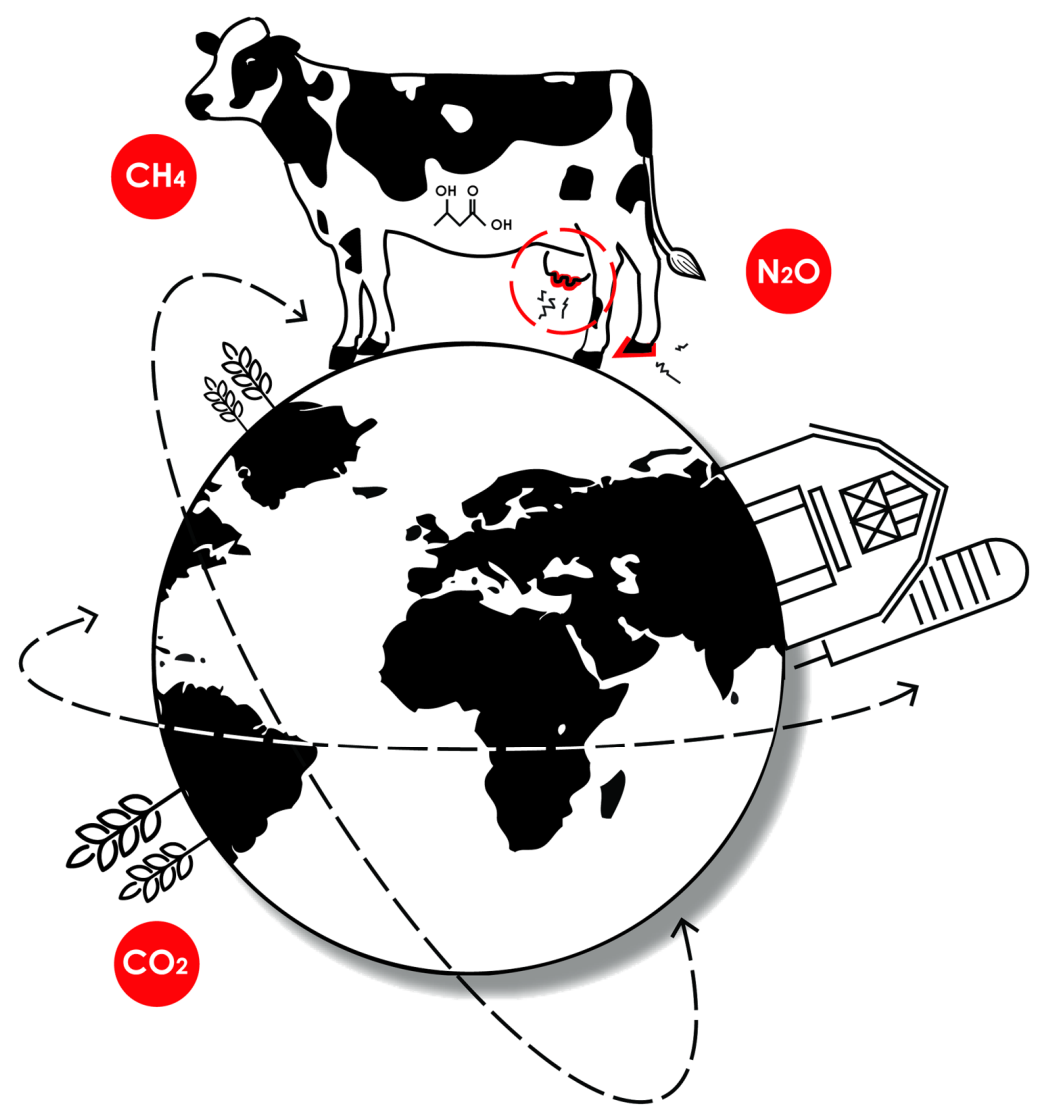


48 | Chapter 3

\section{Abstract}

The dairy sector is an important contributor to greenhouse gas (GHG) emissions. Clinical mastitis (CM), an intramammary infection, has a negative impact on the efficiency of milk production and, therefore, increases GHG emissions per unit of milk. Our objective was to estimate the impact of $\mathrm{CM}$ in dairy cows on GHG emissions of milk production. A dynamic stochastic simulation model was developed to simulate the dynamics and losses of $\mathrm{CM}$ for individual lactations. Cows receive a parity (1-5+), a milk production and a calving interval (CI). Based on the parity, cows have risk of $\mathrm{CM}$, with a maximum of three cases in a lactation. Pathogens causing CM were classified in grampositive bacteria, gram-negative bacteria, or other. Based on the parity and pathogen combinations cows had a reduced milk production, discarded milk, prolonged CI, and a risk of removal (culling and mortality). Using life cycle assessment, emissions of GHGs were estimated from cradle to farm gate for processes along the milk production chain that are affected by CM. Processes included were feed production, enteric fermentation, and manure management. Emissions of GHGs were estimated for cows with and without $\mathrm{CM}$, and were expressed as $\mathrm{kg} \mathrm{CO}_{2}$ equivalents per ton of fatand-protein-corrected milk ( $\mathrm{kg} \mathrm{CO}_{2} \mathrm{e} / \mathrm{t}$ FPCM). Emissions increased on average by $57.5(6.2 \%) \mathrm{kg}$ $\mathrm{CO}_{2} \mathrm{e} / \mathrm{t}$ FPCM per case of CM. This increase was caused by removal (39\%), discarded milk (38\%), reduced milk production (17\%), and prolonged CI (6\%). The GHG emissions increased by $48 \mathrm{~kg}$ $\mathrm{CO}_{2} \mathrm{e} / \mathrm{t}$ FPCM for cows with one case of CM, by $69 \mathrm{~kg} \mathrm{CO} 2 \mathrm{e} / \mathrm{t}$ FPCM for cows with two cases of CM, and by $92 \mathrm{~kg} \mathrm{CO}_{2} \mathrm{e} / \mathrm{t}$ FPCM for cows with three cases of CM. Sensitivity analyses showed that the risk of removal and emissions related to rearing of heifers had an important effect on the results. The increasing attention for global warming is likely to contribute to the introduction of policies or other incentives to reduce GHG emissions related to livestock production, including dairy. Preventing CM is an effective strategy for farmers to reduce GHG emissions, and can contribute to sustainable development of the dairy sector. The impact of CM on GHG emissions, however, will vary between and within countries due to environmental situations and individual farm management practices. Therefore, specific farm analyses are needed to estimate the impact for specific farms. 


\section{Introduction}

One of the most urgent environmental issues is global warming, induced by greenhouse gas (GHG) emissions (Steffen et al., 2015). The livestock sector is responsible for about $14.5 \%$ of the anthropogenic GHG emissions globally (Gerber et al., 2013), of which 30\% is emitted by the dairy sector. Important GHGs related to milk production are carbon dioxide $\left(\mathrm{CO}_{2}\right)$, methane $\left(\mathrm{CH}_{4}\right)$, and nitrous oxide $\left(\mathrm{N}_{2} \mathrm{O}\right)$, mainly emitted during feed production, enteric fermentation of feed, and manure management. The increasing attention for global warming is likely to contribute to the introduction of policies or other incentives to reduce GHG emissions related to livestock production, including dairy. A common method to asses GHG emissions and the impact of mitigation options is life cycle assessment (LCA) that takes into account the entire life cycle of a product (Baumann and Tillmann, 2004). Many studies have used LCA to estimate GHG emissions of milk production, by summing emissions of GHGs along the production chain. Several studies investigated mitigation options (e.g. breeding or feeding) to reduce GHG emissions in the dairy sector (Van Middelaar et al., 2014a; Van Middelaar et al., 2014b). Little attention, however, has been given to the impact of health of dairy cows on GHG emissions. Whereas other strategies to reduce GHG emissions can result in reduced income (Van Middelaar et al., 2014b) or reduced welfare (Llonch et al., 2017), strategies to improve health of dairy cows might benefit the welfare of the animal, farm profitability, and the environment.

Clinical mastitis (CM), an intramammary infection, is one of the most frequent diseases in dairy cows (Seegers et al., 2003). Clinical mastitis can reoccur in the same lactation and across lactations due to several pathogens, which can be classified as gram-positive bacteria (e.g. Streptococcus spp), gram-negative bacteria (e.g. E.coli), or other organisms (Schukken et al., 2009). Dairy cows with CM express illness behaviour after an infection (Fogsgaard et al., 2012) and, therefore, their welfare is considered to be impaired. In addition, $\mathrm{CM}$ has a negative impact on production. Clinical mastitis results in reduced milk production and fertility, and increases culling and mortality of cows (Hertl et al., 2011; Hertl et al., 2014; Schukken et al., 2009). These effects depend on the severity and pathogen type causing CM. The impact of $\mathrm{CM}$ on production affects farm profitability. Additional costs because of CM are estimated between $€ 61-€ 97$ on average per cow per year (Hogeveen et al., 2011) and \$134, \$211, and \$95 per case of respectively gram-positive, gramnegative, and other organisms (Cha et al., 2011).

Besides the negative impact of $\mathrm{CM}$ on farm profitability and on the welfare of cows, CM could also affect GHG emissions of milk production. The negative impact of $\mathrm{CM}$ on production will increase the GHG emissions per unit of milk produced. Hospido and Sonesson (2005) estimated the impact 
50 | Chapter 3

of CM on GHG emissions in Galician dairy herds. This scenario study, however, did not simulate the dynamics of CM per parity (e.g. pathogen type, reoccurrence of CM, and related losses), and did not show the variation in production losses of CM and in emissions of GHGs. Including these aspects can support farmers to make cow specific decisions to prevent CM and reduce GHG emissions.

Our objective was to estimate the impact of CM on GHG emissions per unit of milk, including all processes from cradle to farm gate. By using a dynamic stochastic simulation model on cow level that includes several parities, different pathogens, and multiple occurrence of CM in one lactation, and by performing sensitivity analyses, our study can give new insights in the impact of CM on GHG emissions.

\section{Material and methods}

A dynamic stochastic simulation model was developed in R (R_Core_Team, 2016) and combined with LCA to estimate the impact of CM on GHG emissions per unit of milk. First, the model simulated the dynamics and losses of CM for one lactation. Second, GHG emissions were calculated by using an LCA. The analysis was performed for a predefined Dutch dairy farm applying limited grazing ( $8 \mathrm{~h} /$ day, 170 days/year), which is a common strategy on commercial dairy farms in the Netherlands (Centraal Bureau voor de Statistiek (CBS), 2014). All input values in the model were based on literature. The model was run with 100 ooo iterations.

\section{Model description}

Each cow received a parity (1-5+), based on the average herd composition in the Netherlands (CRV, 2014). Based on the parity, cows received a milk production, body weight and a calving interval (CRV, 2014; CVB, 2012). The calving interval (CI) consisted of a lactation period (350-361 days) and a dry-period (6o days) (Table 1 ).

Based on the parity, cows had a risk of CM. After a first case of CM, cows had a risk of a second case, and a risk of a third case in the same lactation (Table 1). 
Table 1. Cow characteristics and probabilities of clinical mastitis (CM) per parity.

\begin{tabular}{|c|c|c|c|c|c|c|}
\hline Input value & Parity 1 & Parity 2 & Parity 3 & Parity 4 & Parity 5+ & Source \\
\hline Cows (\%) & 33 & 27 & 17 & 11 & 12 & CRV (2014) \\
\hline Milk production (kg/305 days) & 7535 & 8788 & 9383 & 9493 & 9209 & CRV (2014) \\
\hline Milk production advantage $\mathrm{CM}^{1}$ & & & & & & Schukken et al. (2009) \\
\hline Gram-positive (kg/day) & 0.5 & 0.6 & 0.6 & 0.6 & 0.6 & \\
\hline Gram-negative (kg/day) & 1.1 & 2.4 & 2.4 & 2.4 & 2.4 & \\
\hline Other (kg/day) & 0.9 & 0.6 & 0.6 & 0.6 & 0.6 & \\
\hline Weight cow (kg) & 540 & 595 & 650 & 650 & 650 & CVB (2012) \\
\hline Calving interval (day) & 410 & 413 & 415 & 419 & 421 & CRV (2014) \\
\hline Mastitis probability & & & & & & Hertl et al. (2011) \\
\hline First case $(\%)$ & 16.6 & 29.9 & 29.9 & 29.9 & 29.9 & \\
\hline Second case (\% of first case) & 22.3 & 35.8 & 35.8 & 35.8 & 35.8 & \\
\hline Third case (\% of second case) & 30.6 & 40.8 & 40.8 & 40.8 & 40.8 & \\
\hline Days in milk of $\mathrm{CM}$ occurrence & & & & & & Hertl et al. (2011) \\
\hline First case & 129 & 101 & 101 & 101 & 101 & \\
\hline Second case & 204 & 155 & 155 & 155 & 155 & \\
\hline Third case & 252 & 193 & 193 & 193 & 193 & \\
\hline Pathogen type CM & & & & & & Adapted from Hertl et al. (2011) \\
\hline Gram-positive (\%) & 37.3 & 34.3 & 34.3 & 34.3 & 34.3 & \\
\hline Gram-negative (\%) & 32.4 & 40.9 & 40.9 & 40.9 & 40.9 & \\
\hline Other (\%) & 30.3 & 24.8 & 24.8 & 24.8 & 24.8 & \\
\hline
\end{tabular}

Pathogens causing CM were classified in gram-positive, gram-negative, or other to estimate the impact of different pathogens (Hertl et al., 2011). In total, 39 combinations of pathogen types after one, two, and three cases of CM per parity were possible. A case of a specific CM pathogen was not protective for a recurrent case of the same pathogen (Cha et al., 2016). The day of occurrence of the three cases of $\mathrm{CM}$ was fixed in the model and was based on the median of the days of occurrence of CM as found by Hertl et al. (2011) (Table 1). A lactation curve was utilized to estimate the average daily milk production per cow based on weekly milk records (Wood, 1967). To estimate the impact of $\mathrm{CM}$ on milk production, we estimated the difference between the potential and actual milk production of a cow with CM. Potential milk production per cow per lactation was based on average milk production of Dutch dairy cows (CRV, 2014). Cows with CM were assumed to have a higher potential milk production. Their production, therefore, was adapted by adding the daily higher milk production found by Schukken et al. (2009) to the average milk production (Table 1). Reduced milk production resulting from CM was based on the study of Schukken et al. (2009), and depended on parity, type of pathogen, and number of cases of CM. Reduced milk production and type of pathogen causing CM were based on data from studies of the USA, because no detailed data about this were available for a Dutch situation. Cows affected by any pathogen type were treated 
for 3 days with antibiotic, and milk was discarded for 6 days. It was assumed that pathogen identification was not performed by the farmer and that the cows received a broad spectrum antibiotic. This treatment was based on the average treatment protocol of seven veterinarians, who were randomly selected from different clinics in the Netherlands.

Cows with CM could be culled or died (or euthanized) on the farm. Based on parity and type of pathogen, cows with CM had a monthly increased risk of culling and dying, together called removal. To avoid a confounding effect of pregnancy status on the culling decision, there was no risk of removal after month ten (Bar et al., 2008). Removed cows were replaced by an average healthy heifer. To account for the impact on fertility, cows with CM had a prolonged CI of 4 weeks, based on the average impact found by Santos et al. (2004) and Wilson et al. (2008). Because of data limitations, milk production losses and removal were assumed to be not affected by the severity of $\mathrm{CM}$. The discrete events on getting $\mathrm{CM}$ and removal were simulated by drawing random numbers from uniform distributions.

\section{Calculation of greenhouse gas emissions}

An LCA was performed to estimate the impact of $\mathrm{CM}$ on GHG emissions. Emissions of $\mathrm{CO}_{2}, \mathrm{CH}_{4}$, and $\mathrm{N}_{2} \mathrm{O}$ were estimated from cradle to farm gate for processes along the milk production chain that are affected by CM. Processes included were feed production, enteric fermentation, and manure management. Emissions related to the production of antibiotics were assumed to be minor and, therefore, were excluded. Emissions of GHGs were estimated for cows with and without CM, and were expressed as $\mathrm{kg} \mathrm{CO}_{2}$ equivalents $\left(\mathrm{CO}_{2} \mathrm{e}\right)$ per ton of fat-and-protein-corrected milk (FPCM). Different GHGs were summed up based on their equivalent factor: 1 for $\mathrm{CO}_{2}, 28$ for biogenic $\mathrm{CH}_{4}, 30$ for fossil $\mathrm{CH}_{4}$, and 265 for $\mathrm{N}_{2} \mathrm{O}$ (100-year time horizon) (Myhre et al., 2013). The impact of CM on GHG emissions was the difference in emissions per kg FPCM between a cow without (potential production) and with (actual production) CM. To gain insight in the largest contributors, the impact of CM on GHG emissions was analysed per process (feed production, enteric fermentation, manure management), per parity, per production contributor (reduced milk production, discarded milk, prolonged CI, removal), and per pathogen combination. The last analysis was based on 100 ooo cows with CM to increase the number of cows with multiple cases of CM. This reduced the uncertainty to less than 1 percent on total emissions per combination of pathogens. The estimation of GHG emissions is described in detail in Mostert et al. (2018) and, therefore, only briefly described below. 
Based on national statistics of the Netherlands, a summer (170 days/year) and winter diet (195 days/year), were composed (CBS, 2014). Feed ingredients included concentrates and roughage (grass, grass silage, maize silage). Feed intake (kg DM/ cow) was estimated based on the energy content of the diet and the energy requirements of the cow. These energy requirements for maintenance, milk production and pregnancy, and energy requirements for growth in case of parity 1 and 2 were estimated per day (CVB, 2012). Energy requirement for maintenance was assumed to be $6.7 \%$ higher in summer than in winter because of grazing (CVB, 2012).

Emissions of GHGs related to feed production were based on Vellinga et al. (2013) (Table 2). Processes included were the production of inputs (e.g. fertilizers, pesticides, machinery, energy), cultivation and harvesting of the crops (including fertilizer application), processing and drying of feed ingredients, and transport between processing steps up to the farm gate. In addition to the processes described above, emissions related to land use ( $\mathrm{Lu}$ ) and land use change (Luc) also were included (Vellinga et al., 2013).

Emissions from enteric fermentation were based on Vellinga et al. (2013). Emissions from manure were estimated based on national inventory reports and IPCC (2006). Nitrogen (N) excretion, which was used to calculate $\mathrm{N}$ emissions from manure management, was estimated based on $\mathrm{N}$ intake of the cow, $\mathrm{N}$ retention in milk, and in growth of the cow and calf. Direct $\mathrm{N}_{2} \mathrm{O}$ emissions, indirect $\mathrm{N}_{2} \mathrm{O}$

Table 2. Greenhouse gas emissions of feed production and land use and land use change (LULuc), enteric methane emissions, and energy and nitrogen content of summer and winter diet.

\begin{tabular}{lll}
\hline Input variable $^{1}$ & Summer diet & Winter diet \\
\hline Energy of feed (MJ/ kg DM) & 6.8 & 6.5 \\
Nitrogen content (g / $/ \mathrm{kg} \mathrm{DM})$ & 30.3 & 26.8 \\
Feed production $\left(\mathrm{g} \mathrm{CO}_{2} \mathrm{e} / \mathrm{kg} \mathrm{DM}\right)^{2}$ & 470 & 468 \\
LULuc $\left(\mathrm{g} \mathrm{CO}_{2} \mathrm{e} / \mathrm{kg} \mathrm{DM}\right)$ & 87 & 94 \\
Enteric methane $\left(\mathrm{g} \mathrm{CH}_{4} / \mathrm{kg} \mathrm{DM}\right)$ & 20.9 & 20.5 \\
\hline
\end{tabular}

${ }^{1}$ Vellinga et al. (2013)

${ }^{2} \mathrm{CO}_{2} \mathrm{e}$ : carbon dioxide equivalent, $\mathrm{CH}_{4}$ : methane

emissions (i.e. $\mathrm{N}_{2} \mathrm{O}$ derived from volatilization of ammonia $\left(\mathrm{NH}_{3}\right)$ and nitrogen oxides $\left(\mathrm{NO}_{\mathrm{x}}\right)$ and from leaching of nitrate $\left(\mathrm{NO}_{3}^{-}\right)$) and $\mathrm{CH}_{4}$ emissions from manure in stables and storage, and from manure deposited during grazing were included. More details about emission factors can be found in Supplementary Table S1. 


\section{$\mathbf{5 4}$ | Chapter 3}

System expansion was applied to account for the production of meat from calves and cows. Consequences of meat production in terms of GHG emissions were based on the so-called avoidedburden method (Guinée et al., 2002). This method assumes that meat from cows replaces alternative products on the market, and therefore subtracts GHG emissions related to the production of those avoided products from the emissions related to dairy production. Cows that were removed before the end of parity 5 were assumed to be removed too early, resulting in rearing extra heifers. This increases emissions related to non-productive animals. Additional emissions because of removal were estimated as the difference between the emissions of rearing a heifer and the avoided burden of the meat production from that cow. Subsequently, this difference was depreciated over the age of the cow, resulting in a lower impact of removal from older cows (Mostert et al., 2018).

\section{Sensitivity analysis}

Sensitivity analyses were performed to analyse the impact of changes in production parameters and in GHG emission factors. Results of changes were compared with results of the reference situation (Table 1, 2). Input parameters were adjusted based on the variation found in literature and analysed separately. The impact of CM on milk production was doubled (Increased impact milk production) (Seegers et al., 2003). The risk of removal resulting from CM was increased by 50\% (Increased risk remova) (Seegers et al., 2003). The prolonged CI was increased from 28 days to 56 days (Increased prolonged calving interval) (Ahmadzadeh et al., 2009).

The impact of changes in GHG emission factors were analysed to assess the impact of the GHG emission factors that were used and to assess the potential impact of differences in feeding strategy, feed composition, and manure management between farms. Based on variation found in literature, the most important emission factors were changed. Emissions related to the production of feed were changed by $\pm 25 \%$ (Emissions feed) (Van Middelaar et al., 2013). Emissions related to enteric fermentation were changed by $\pm 20 \%$ (Emissions enteric) (IPCC, 2006). Emissions related to rearing a heifer were changed by $\pm 25 \%$ (Emissions heifer). Emissions of $\mathrm{CH}_{4}$ and $\mathrm{N}_{2} \mathrm{O}$ related to manure storage and grazing were changed by $\pm 100 \%$ (Emissions manure) (Olivier et al., 2009). 


\section{Results}

\section{Impact of clinical mastitis on greenhouse gas emissions}

Emissions of GHGs increased on average by 57.5 (6.2\%) $\mathrm{kg} \mathrm{CO}_{2} \mathrm{e} / \mathrm{t}$ FPCM per case of CM, with a range between 17.6 and 173.6 (5-95 percentiles) $\mathrm{kg} \mathrm{CO}_{2} \mathrm{e} / \mathrm{t}$ FPCM. Emissions related to feed production and enteric fermentation contributed most to the total emissions (Table 3 ).

Table 3. Greenhouse gas (GHG) emissions per ton fat-and-protein-corrected milk $\left(\mathrm{kg} \mathrm{CO}_{2} \mathrm{e} / \mathrm{t}\right.$ FPCM) of dairy cows with no clinical mastitis (CM), and a cow with CM, and the difference related to feed production, enteric methane, land use and land use change (LULuc), manure, avoided burden, and rearing extra heifers.

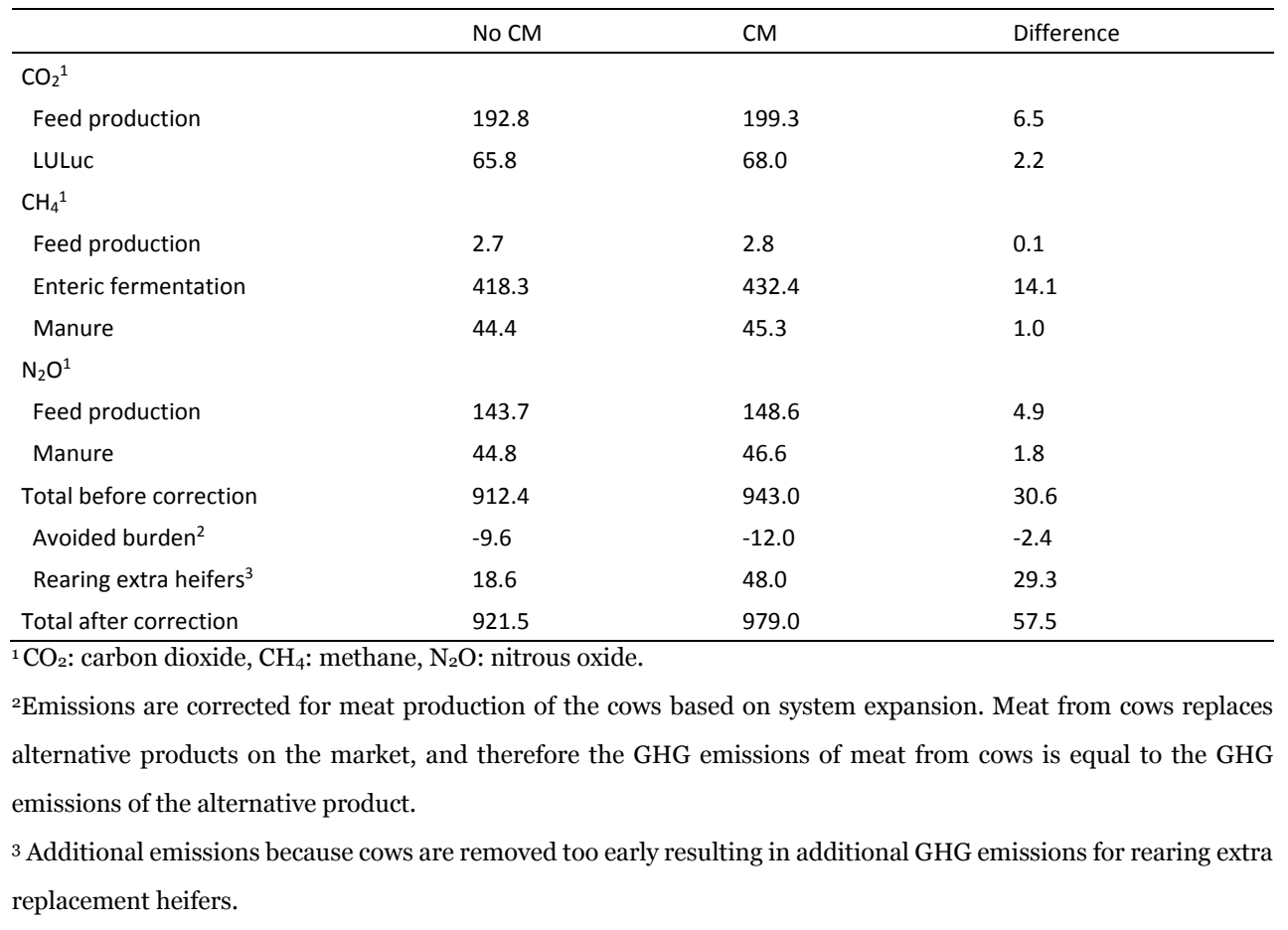

With regard to the production parameters, the increase in GHG emissions per case of CM was caused by removal (39\%), discarded milk (38\%), reduced milk production (17\%), and prolonged CI (6\%) (Table 4).

The increase in GHG emissions per case of CM per parity varied from $75(33-204) \mathrm{kg} \mathrm{CO}_{2} \mathrm{e} / \mathrm{t} \mathrm{FPCM}$ in parity 1 to 34 (15-60) $\mathrm{kg} \mathrm{CO}_{2} \mathrm{e} / \mathrm{t} \mathrm{FPCM}$ in parity 5. In the months after the first case of CM, 40\% of cows with $\mathrm{CM}$ were removed, whereas in the same period $17 \%$ of cows without $\mathrm{CM}$ were 
$\mathbf{5 6}$ | Chapter 3

removed. Clinical mastitis reduced the milk production of cows that were not removed on average by $4.5 \%$.

The increase in GHG emissions was $48 \mathrm{~kg} \mathrm{CO}_{2} \mathrm{e} / \mathrm{t}$ FPCM for cows with one case of CM, $69 \mathrm{~kg} \mathrm{CO}_{2} \mathrm{e} / \mathrm{t}$ FPCM for cows with two cases of $\mathrm{CM}$, and $92 \mathrm{~kg} \mathrm{CO}_{2} \mathrm{e} / \mathrm{t}$ FPCM for cows with three cases of CM (Figure 1). The increase in GHG emissions per case of CM varied between the type of pathogens, and was highest if the first case of $\mathrm{CM}$ was gram-negative (average of dark grey bars: $65 \mathrm{~kg} \mathrm{CO}_{2} \mathrm{e} / \mathrm{t}$ FPCM), followed by gram-positive (average of black bars: $54 \mathrm{~kg} \mathrm{CO}_{2} \mathrm{e} / \mathrm{t} \mathrm{FPCM}$ ) and other (average of light grey bars: $51 \mathrm{~kg} \mathrm{CO} 2 \mathrm{e} / \mathrm{t}$ FPCM). The impact of $\mathrm{CM}$ was highest when cows were culled because of $\mathrm{CM}$ (115 $\mathrm{kg} \mathrm{CO}_{2} \mathrm{e} / \mathrm{t}$ FPCM), and when cows died because of $\mathrm{CM}$ (322 $\mathrm{kg} \mathrm{CO}_{2} \mathrm{e} / \mathrm{t} \mathrm{FPCM}$ ).

Table 4. Average increase of greenhouse gas (GHG) emissions per ton fat-and-protein-corrected milk ( $\mathrm{kg} \mathrm{CO}_{2} \mathrm{e} / \mathrm{t} \mathrm{FPCM}$ ) per parity due to clinical mastitis (5-95 percentiles) in dairy cows related to reduced milk production, discarded milk, prolonged calving interval, removal, and avoided burden.

\begin{tabular}{lllllll}
\hline Contributor & Parity 1 & Parity 2 & Parity 3 & Parity 4 & Parity 5+ & Average $^{1}$ \\
\hline Reduced milk production & $14(2-24)$ & $11(2-28)$ & $9(1-19)$ & $7(1-18)$ & $8(1-19)$ & $10(1-22)$ \\
Discarded milk & $20(12-39)$ & $24(11-48)$ & $24(11-48)$ & $23(11-47)$ & $23(11-47)$ & $23(11-47)$ \\
Prolonged calving interval & $3(0-4)$ & $5(0-8)$ & $4(0-7)$ & $3(0-7)$ & $3(0-7)$ & $4(0-7)$ \\
Removal & $39(0-187)$ & $20(0-144)$ & $25(0-120)$ & $21(0-85)$ & $5(-13-32)$ & $23(0-141)$ \\
Avoided burden ${ }^{2}$ & $-1(-3-0)$ & $-1(-3-0)$ & $-3(-15-0)$ & $-5(-14-0)$ & $-4(-14-0)$ & $-2(-14-0)$ \\
Total & $75(33-204)$ & $60(19-169)$ & $58(18-127)$ & $49(17-89)$ & $34(15-60)$ & $58(18-174)$ \\
\hline
\end{tabular}

${ }^{1} \mathrm{~A}$ weighted average for all parities was taken which was based on the composition of an average Dutch dairy herd

${ }^{2}$ Emissions are corrected for meat production of the cows based on system expansion. Meat from cows replaces alternative products on the market, and therefore the GHG emissions of meat from cows is equal to the GHG emissions of the alternative product. 


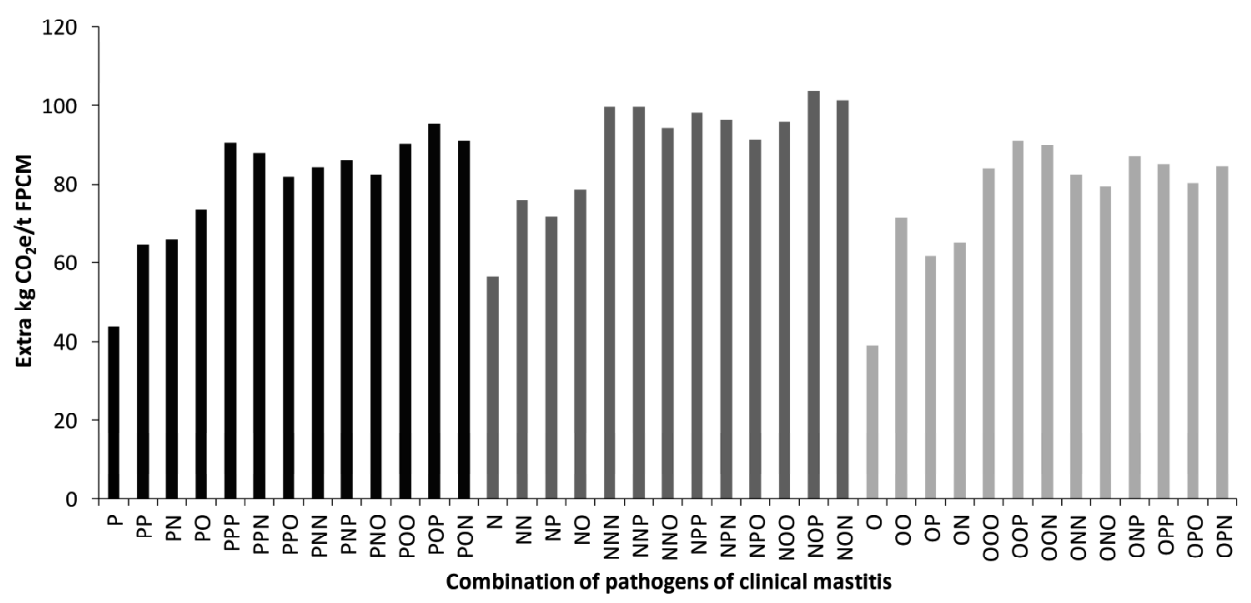

Figure 1. Average increase of greenhouse gas emissions per ton fat-and-protein-corrected milk ( $\mathrm{kg} \mathrm{CO}_{2} \mathrm{e} / \mathrm{t}$ FPCM) of clinical mastitis in dairy cows per type of pathogen; gram-positive (P), gramnegative $(\mathrm{N})$, or other $(\mathrm{O})$, and the combinations up to three cases.

\section{Sensitivity analysis}

Results of the effect of a change in emission factors and production parameters on the impact of $\mathrm{CM}$ on $\mathrm{CO}_{2} \mathrm{e} / \mathrm{t}$ FPCM are shown in Figure 2, relative to the reference situation (\%). The two parameters related to removal had the highest impact. Increasing the removal risk of cows with $\mathrm{CM}$ increased the GHG emissions by $19 \%$, whereas increasing the emissions of rearing a heifer increased the emissions by $21 \%$. Increasing prolonged CI increased GHG emissions by $8 \%$, whereas doubling the impact of $\mathrm{CM}$ on milk production increased GHG emissions by $4 \%$. A decrease in emissions related to production of feed, enteric fermentation, and manure storage and grazing, resulted in a similar but opposite effect (results not shown). 


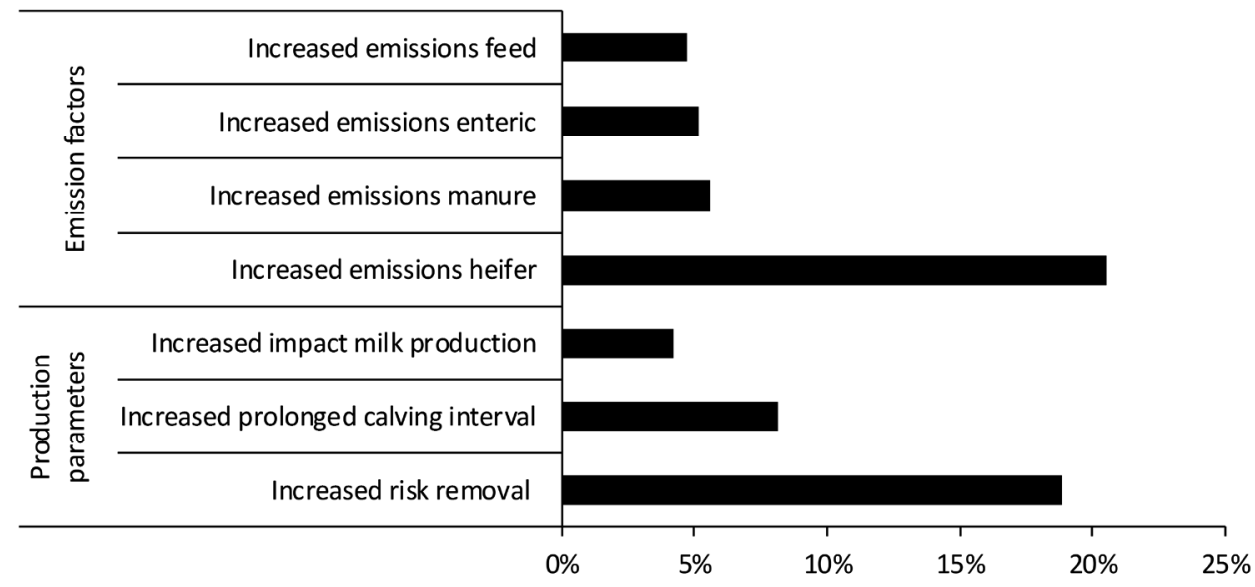

Figure 2. Results from the sensitivity analyses showing the effect (\%) of a change in input parameters of emission factors, and production parameters on the impact of clinical mastitis in dairy cows on greenhouse gas emissions per ton fat-and-protein-corrected milk $\left(\mathrm{kg} \mathrm{CO}_{2} \mathrm{e} / \mathrm{t} \mathrm{FPCM}\right)$ compared to the reference situation.

\section{Discussion}

The relation between animal health and GHG emissions has been estimated only in a few studies. Mostert et al. (2018) showed that a case of subclinical ketosis increased GHG emissions by 2.3\%. Preventing a case of CM can reduce GHG emissions of a dairy cow by $6.2 \%$. Clinical mastitis has a larger impact on production than subclinical ketosis and, therefore, $\mathrm{CM}$ also has a larger impact on GHG emissions. On herd level, with an incidence of $27 \%$ of one case of CM, GHG emissions increase by $1.7 \%$ (16 kg CO $2 \mathrm{e} / \mathrm{t}$ FPCM). Using a scenario study, Hospido and Sonesson (2005) showed that reducing subclinical mastitis (subCM) by $18 \%$ and $\mathrm{CM}$ by $7 \%$ reduced GHG emissions by $2.5 \%$ at herd level. We were not able to include subCM, because no data were available about the relation between $\mathrm{CM}$ and subCM. We, therefore, found a lower GHG impact of CM than Hospido and Sonesson (2005). The reduction of subCM and CM in the study of Hospido and Sonesson (2005), however, resulted in an unlikely increase in milk production of more than 30 ooo $\mathrm{kg}$ from 14 cows that were not affected in the improved situation. Milk production losses of mastitis result on average in a loss of $5 \%(375 \mathrm{~kg})$ over a full lactation (Seegers et al., 2003), which is much lower than used by Hospido and Sonesson (2005). Hospido and Sonesson (2005), therefore, may have overestimated the impact of CM on GHG emissions. 
Literature shows differences in losses in milk production, removal, and fertility as a result of CM (Seegers et al., 2003). Milk production losses and type of pathogen causing CM were based on data from studies of the USA. In our model, we assumed that the reoccurrence of a pathogen and related milk production losses were the same for the Dutch situation, although these cows have a lower potential milk production. It is unknown if the magnitude of loss depends on the production level of the cow (Seegers et al., 2003). Milk production losses in our study were $4.5 \%$, which is lower than $5 \%$ found by Seegers et al. (2003), which could have resulted in an underestimation of the impact of CM on GHG emissions.

Removal of cows is farm specific and has varied between literature studies. In our study, cows with $\mathrm{CM}$ had a risk ratio of 2.4 for removal, which is within the range of 1.5-5.0 given by Seegers et al. (2003). Removal was an important contributor to the impact of CM on GHG emissions. Sensitivity analyses showed that GHG emissions for rearing a new heifer and removal risk had an important impact on the results. These two aspects can result in high variation between farms.

Fertility had the lowest contribution to the total impact of CM. In our model, however, the impact of fertility on removal was excluded because of lack of data. Including these removals will increase GHG emissions. It was assumed that type of pathogen did not influence fertility. Type of pathogen, parity, and time of $\mathrm{CM}$ occurrence before or after $\mathrm{AI}$, however, can have an impact on the probability of conception (Hertl et al., 2010). Gram-negative bacteria have in general a higher effect on probability of conception than gram-positive bacteria, or other pathogens. The impact of gram-negative combinations, therefore, might have been underestimated. In our model, the impact of CM on fertility was simplified, because we did not have the data to include a detailed fertility model. Including a more detailed fertility model can improve the estimation of GHG emissions for specific pathogen combinations.

High variation was found between different pathogens. The impact on milk losses and removal for different combinations of pathogens was included. Treatment, however, was equal for all pathogens, because it was assumed that farmers, in general, are not aware of the type of pathogen and therefore use a broad spectrum antibiotic. Including a specific treatment per pathogen can have an impact on GHG emissions for specific pathogen combinations.

Current incentives to reduce diseases in dairy cows aim to increase the income of the farmer and to improve animal welfare and will become even more relevant when policies to reduce GHG emissions are implemented for the livestock sector. Preventive measures to reduce CM can be management practices (e.g. washing dirty udders and the use of milkers' gloves), treatment of subCM, or vaccination. The economic impact of these strategies has been estimated (Hogeveen et al., 2011; Kessels et al., 2016), but the impact of these strategies on global warming and other 
6o | Chapter 3

environmental impact categories has not been estimated. Incidence of $\mathrm{CM}$ ranges from 2 to $82 \%$ on dairy farms in the Netherlands (van Soest et al., 2016). Farms with a high incidence of CM have a high potential to reduce CM and consequently GHG emissions.

Several other strategies have been investigated to reduce GHG emissions in the dairy sector. Dietary supplements or drugs can reduce enteric $\mathrm{CH}_{4}$ emissions of dairy cows, but some might have a negative impact on cow welfare (Llonch et al., 2017) or are not allowed in some countries (e.g. recombinant bovine somatotropin (rbST)). Meul et al. (2014) showed that the most important contributors (in units per kg FPCM) to GHG emissions of milk production were DM intake of the dairy cow and heifer, application of $\mathrm{N}$ from mineral fertilizer and manure, and amount (kg DM) of purchased concentrates and soybean meal. Preventing CM improves all these three aspects, because the efficiency of milk production increases. Moreover, preventing CM might be more effective for reducing GHG emissions than adopting a feeding strategy (9-32 $\mathrm{kg} \mathrm{CO}_{2} \mathrm{e} / \mathrm{t} \mathrm{FPCM}$ ) (Van Middelaar et al., 2014b) or increasing milk yield by $698 \mathrm{~kg} /$ year per cow and longevity by 270 days per cow (27 and $23 \mathrm{~kg} \mathrm{CO}_{2} \mathrm{e} / \mathrm{t} \mathrm{FPCM}$ ) (Van Middelaar et al., 2014a). In addition, changing the feeding strategy can reduce GHG emissions of a dairy farm, but does not always increase the income of the farmer (Van Middelaar et al., 2014b). Overall, preventing CM increases the income of the farmer, improves the welfare and longevity of the dairy cow, reduces GHG emissions, and therefore is an effective strategy that contributes to sustainable development of the dairy sector. The impact of CM on GHG emissions and other environmental aspects, however, will vary between and within countries due to environmental situations (e.g. climate) and management practices (e.g. milk production, removal, feed and manure management). Therefore, specific farm analyses are needed to estimate the impact of that farm on GHG emissions. 


\section{References}

Ahmadzadeh, A., Frago, F., Shafii, B., Dalton, J.C., Price, W.J., McGuire, M.A., 2009. Effect of clinical mastitis and other diseases on reproductive performance of Holstein cows. Anim. Reprod. Sci. 112, 273-282.

Bar, D., Gröhn, Y.T., Bennett, G., González, R.N., Hertl, J.A., Schulte, H.F., Tauer, L.W., Welcome, F.L., Schukken, Y.H., 2008. Effects of repeated episodes of generic clinical mastitis on mortality and culling in dairy cows. J. Dairy Sci. 91, 2196-2204.

Baumann, H., Tillmann, A., 2004. The hitch hiker's guide to LCA An orientation in life cycle assessment methodology and application. Studentlitteratur AB, Lund, Sweden.

Cha, E., Bar, D., Hertl, J.A., Tauer, L.W., Bennett, G., González, R.N., Schukken, Y.H., Welcome, F.L., Gröhn, Y.T., 2011. The cost and management of different types of clinical mastitis in dairy cows estimated by dynamic programming. J. Dairy Sci. 94, 4476-4487.

Cha, E., Hertl, J., Schukken, Y., Tauer, L., Welcome, F., Gröhn, Y., 2016. Evidence of no protection for a recurrent case of pathogen specific clinical mastitis from a previous case.

J. Dairy Res. 83, 72-80.

CBS, 2014. Centraal Bureau voor de Statistiek. Dierlijke mest en mineralen 2013 (Animal manure and minerals 2013). CBS, Den Haag, the Netherlands.

CRV, 2014. International Dutch cattle improvement co-operative. Jaarstatistieken 2014 voor Nederland (Annual statistics 2014). CRV, Arnhem, the Netherlands.

CVB, 2012. Centraal Veevoederbureau. Tabellenboek Veevoeding 2012, voedernormen landbouwhuisdieren en voederwaarde veevoeders (Composition and nutritional values of feedstuffs and requirement values), CVB-reeks nr.50, August 2012. Productschap Diervoeder, Den Haag, the Netherlands.

Fogsgaard, K.K., Røntved, C.M., Sørensen, P., Herskin, M.S., 2012. Sickness behavior in dairy cows during Escherichia coli mastitis. J. Dairy Sci. 95, 630-638.

Gerber, P.J., Steinfeld, H., Henderson, B., Mottet, A., Opio, C., Dijkman, J., Falcucci, A., Tempio, G., 2013. Tackling climate change through livestock - A global assessment of emissions and mitigation opportunities. Food and Agriculture Organization of the United Nations (FAO), Rome, Italy.

Guinée, J., Gorrée, M., Heijungs, R., Huppes, G., Kleijn, R., de Koning, A., van Oers, L., Wegener Sleeswijk, A., Suh, S., Udo de Haes, H., de Bruijn, H., van Duin, R., Huijbregts, M., Lindeijer, E., Roorda, A., van der Ven, B., Weidema, B.e., 2002. Handbook on life cycle assessment. Operational guide to the ISO standards. Kluwer, Leiden, The Netherlands.

Hertl, J.A., Gröhn, Y.T., Leach, J.D.G., Bar, D., Bennett, G.J., González, R.N., Rauch, B.J., Welcome, F.L., Tauer, L.W., Schukken, Y.H., 2010. Effects of clinical mastitis caused by gram-positive and gram-negative bacteria and other organisms on the probability of conception in New York State Holstein dairy cows. J. Dairy Sci. 93, 1551-1560. 
62 | Chapter 3

Hertl, J.A., Schukken, Y.H., Bar, D., Bennett, G.J., González, R.N., Rauch, B.J., Welcome, F.L., Tauer, L.W., Gröhn, Y.T., 2011. The effect of recurrent episodes of clinical mastitis caused by gram-positive and gram-negative bacteria and other organisms on mortality and culling in Holstein dairy cows. J. Dairy Sci. 94, 4863-4877.

Hertl, J.A., Schukken, Y.H., Welcome, F.L., Tauer, L.W., Gröhn, Y.T., 2014. Effects of pathogenspecific clinical mastitis on probability of conception in Holstein dairy cows. J. Dairy Sci. 97, 6942-6954.

Hogeveen, H., Huijps, K., Lam, T., 2011. Economic aspects of mastitis: New developments. N. Z. Vet. J. 59, 16-23.

Hospido, A., Sonesson, U., 2005. The environmental impact of mastitis: a case study of dairy herds. Sci. Total Environ. 343, 71-82

IPCC, 2006. 2006 Intergovernmental Panel on Climate Change. Guidelines for National Greenhouse Gas Inventories. Volume 4: Agriculture, forestry and other land use. In Emissions from livestock and manure managament (ed. Eggleston, H.S., Buendia, L., Miwa, K., Ngara, T., Tanable, K.). IGES, Japan.

Kessels, J.A., Cha, E., Johnson, S.K., Welcome, F.L., Kristensen, A.R., Gröhn, Y.T., 2016.

Economic comparison of common treatment protocols and $\mathrm{J}_{5}$ vaccination for clinical mastitis in dairy herds using optimized culling decisions. J. Dairy Sci. 99, 3838-3847.

Llonch, P., Haskell, M.J., Dewhurst, R.J., Turner, S.P., 2017. Current available strategies to mitigate greenhouse gas emissions in livestock systems: an animal welfare perspective. Animal 11, 274-284.

Meul, M., van Middelaar, C.E., de Boer, I.J.M., Van Passel, S., Fremaut, D., Haesaert, G., 2014. Potential of life cycle assessment to support environmental decision making at commercial diary farms. Agric. Syst. 131, 05-115

Mostert, P.F., van Middelaar, C.E., Bokkers, E.A.M., de Boer, I.J.M., 2018. The impact of subclinical ketosis in dairy cows on greenhouse gas emissions of milk production. J Clean Prod. 171, 773-782.

Myhre, G., Shindell, D., Bréon, F.-M., Collins, W., Fuglestvedt, J., J. Huang, D.K., Lamarque, J.F., Lee, D., Mendoza, B., Nakajima, T., Robock, A., Stephens, G., Takemura, T., H. Zhang, 2013. Anthropogenic and Natural Radiative Forcing. In: Climate Change 2013: The Physical Science Basis. Contribution of Working Group I to the Fifth Assessment Report of the Intergovernmental Panel on Climate Change [Stocker, T.F., Qin, D., Plattner, G.-K., Tignor, M., Allen, S.K., Boschung, J., Nauels, A., Xia, Y., Bex, V., Midgley P.M., (eds.)]. Cambridge University Press, Cambridge, United Kingdom.

Olivier, J.G.J., Brandes, L.J., te Molder, R.A.B., 2009. Uncertainty in the Netherlands' greenhouse gas emissions inventory Estimation of the level and trend uncertainty using the IPCC Tier 1 approach. Environmental Assessment Agency (PBL), Den Haag, the Netherlands. 
R_Core_Team, 2016. R: A language and environment for statistical computing. R Foundation for Statistical Computing, Vienna, Austria. Retrieved on 4 July 2016, from http://www.Rprojetc.org/.

Santos, J.E.P., Cerri, R.L.A., Ballou, M.A., Higginbotham, G.E., Kirk, J.H., 2004. Effect of timing of first clinical mastitis occurence on lactational and reproductive performance of Holstein diary cows. Anim. Reprod. Sci. 80, 31-45.

Schukken, Y.H., Hertl, J., Bar, D., Bennett, G.J., González, R.N., Rauch, B.J., Santisteban, C., Schulte, H.F., Tauer, L., Welcome, F.L., Gröhn, Y.T., 2009. Effects of repeated grampositive and gram-negative clinical mastitis episodes on milk yield loss in Holstein dairy cows. J. Dairy Sci. 92, 3091-3105.

Seegers, H., Fourichon, C., Beaudeau, F., 2003. Production effects related to mastitis and mastitis economics in dairy cattle herds. Vet. Res. 34, 475-491.

Steffen, W., Richardson, K., Rockström, J., Cornell, S.E., Fetzer, I., Bennett, E.M., Biggs, R., Carpenter, S.R., de Vries, W., de Wit, C.A., Folke, C., Gerten, D., Heinke, J., Mace, G.M., Persson, L.M., Ramanathan, V., Reyers, B., Sörlin, S., 2015. Planetary boundaries: Guiding human development on a changing planet. Science 347.

Van Middelaar, C.E., Berentsen, P.B.M., Dijkstra, J., van Arendonk, J.A.M., de Boer, I.J.M., 2014a. Methods to determine the relative value of genetic traits in dairy cows to reduce greenhouse gas emissions along the chain. J. Dairy Sci. 97, 5191-5205.

Van Middelaar, C.E., Cederberg, C., Vellinga, T.V., Van Der Werf, H.M.G., De Boer, I.J.M., 2013. Exploring variability in methods and data sensitivity in carbon footprints of feed ingredients. Int J Life Cycle Assess 18, 768-782.

Van Middelaar, C.E., Dijkstra, J., Berentsen, P.B.M., De Boer, I.J.M., 2014b. Cost-effectiveness of feeding strategies to reduce greenhouse gas emissions from dairy farming. J. Dairy Sci. 97, 2427-2439.

van Soest, F.J.S., Santman-Berends, I.M.G.A., Lam, T.J.G.M., Hogeveen, H., 2016. Failure and preventive costs of mastitis on Dutch dairy farms. J. Dairy Sci. 99, 8365-8374.

Vellinga, T.V., Blonk, H., Marinussen, M., Van Zeist, W.J., De Boer, I.J.M., 2013. Methodology Used in Feedprint: A Tool Quantifying Greenhouse Gas Emissions of Feed Production and Utilization. Wageningen UR Livestock research, Lelystad, the Netherlands.

Wilson, D.J., Grohn, Y.T. Bennett, G.J., González, R.N., Schukken, Y.K., Spatz, J., 2008. Milk production change following clinical mastitis and reproductive performance compared among J5 vaccinated and control dairy cattle. J. Dairy Sci. 91, 3869-1879.

Wood, P.D.P., 1967. Algebraic model of the lactation curve in cattle. Nature 216, 164-165. 
64 | Chapter 3

\section{Supplementary material}

Supplementary Table S1. Emissions factors for $\mathrm{CH}_{4}$ and $\mathrm{N}_{2} \mathrm{O}$ emissions, $\mathrm{NO}_{3}-\mathrm{N}$ leaching and $\mathrm{NH}_{3}-\mathrm{N}+\mathrm{NO}_{\mathrm{X}}-\mathrm{N}$ volatizing of manure in stable and manure from grazing.

\begin{tabular}{|c|c|c|c|}
\hline \multicolumn{4}{|l|}{ Stable/storage } \\
\hline $\mathrm{N}_{2} \mathrm{O}-\mathrm{N}$ direct & $\mathrm{kg} / \mathrm{kg} \operatorname{TAN}^{\mathrm{a}}$ & 0.0015 & De Vries et al. (2011) \\
\hline $\mathrm{NH}_{3}-\mathrm{N}$ & $\mathrm{kg} / \mathrm{kg}$ TAN & 0.1000 & De Vries et al. (2011) \\
\hline $\mathrm{NO}_{x}-\mathrm{N}$ & $\mathrm{kg} / \mathrm{kg}$ TAN & 0.0015 & De Vries et al. (2011) \\
\hline $\mathrm{CH}_{4}$ & $\mathrm{~kg} /$ ton manure & 0.746 & De Mol and Hilhorst (2003) \\
\hline \multicolumn{4}{|l|}{ Grazing } \\
\hline $\mathrm{N}_{2} \mathrm{O}-\mathrm{N}$ direct & $\mathrm{kg} / \mathrm{kg} \mathrm{N}$ & 0.033 & Vonk et al. (2016) \\
\hline NOx-N & $\mathrm{kg} / \mathrm{kg} \mathrm{N}$ & 0.012 & Vonk et al. (2016) \\
\hline $\mathrm{NH}_{3}-\mathrm{N}^{\mathrm{b}}$ & $\mathrm{kg} / \mathrm{kg}$ TAN & 0.053 & Vonk et al. (2016) \\
\hline $\mathrm{NO}_{3}-\mathrm{N}$ leach & $\mathrm{kg} / \mathrm{kg} \mathrm{N}$ & 0.12 & Velthof and Mosquera (2011) \\
\hline $\mathrm{CH}_{4}$ & $\mathrm{~kg} / \mathrm{m}^{3}$ manure & 0.11 & De Mol and Hilhorst (2003) \\
\hline \multicolumn{4}{|l|}{ All } \\
\hline \multirow[t]{2}{*}{$\mathrm{N}_{2} \mathrm{O}-\mathrm{N}$ indirect } & $\mathrm{kg} / \mathrm{kg} \mathrm{NH}-\mathrm{N}+\mathrm{NO}_{x}-\mathrm{N}$ & 0.01 & IPCC (2006) \\
\hline & $\mathrm{kg} / \mathrm{kg} \mathrm{NO}-\mathrm{N}$ & 0.0075 & IPCC (2006) \\
\hline
\end{tabular}

a TAN $=$ Total Ammoniacal Nitrogen

${ }^{\mathrm{b}} \mathrm{EF} \mathrm{NH}_{3}$ grazing $=1.98 \times 10^{-5} \times(\text { Ncontentdiet })^{3.664}$ 


\section{References}

De Mol, R.M., Hilhorst, M.A., 2003. Emissions of methane, nitrous oxide and ammonia from production, storage and transport of manure. Institute of Agricultural and Environmental Engineering, Wageningen, the Netherlands.

De Vries, J.W., Hoeksma, P., Groenestein, C.M., 2011. LevensCyclusAnalyse (LCA) pilot mineralenconcentraten. Wageningen UR Livestock Research, Wageningen, the Netherlands.

IPCC, 2006. 2006 Intergovernmental Panel on Climate Change. Guidelines for National

Greenhouse Gas Inventories. Volume 4: Agriculture, forestry and other land use. In Emissions from livestock and manure managament (ed. Eggleston, H.S., Buendia, L., Miwa, K., Ngara, T., Tanable, K.). IGES, Japan.

Velthof, G.L., Mosquera, J., 2011. Calculation of nitrous oxide emission from agriculture in the Netherlands. Alterra, Wageningen, the Netherlands.

Vonk, J., Bannink, A., van Bruggen, C., Groenestein, C.M., Huijsmans, J.F.M., van der Kolk, J.W.H., Luesink, H.H., Oude Voshaar, S.V., van der Sluis, S.M., Velthof, G.L., 2016. Methodology for estimating emissions from agriculture in the Netherlands Calculations of $\mathrm{CH}_{4}, \mathrm{NH}_{3}, \mathrm{~N} 2 \mathrm{O}, \mathrm{NOx}, \mathrm{PM} 10, \mathrm{PM}_{2} .5$ and $\mathrm{CO}_{2}$ with the National Emission Model for Agriculture (NEMA). Wageningen, The Statutory Research Tasks Unit for Nature and the Environment (WOT Natuur \& Milieu), Wageningen, the Netherlands. 



\section{Chapter 4}

The impact of foot lesions in dairy cows on greenhouse gas emissions of milk production

P.F. Mostert, C.E. van Middelaar, I.J.M. de Boer, E.A.M. Bokkers

Animal Production Systems group, Wageningen University \& Research, PO Box 338, 6700 AH

Wageningen, the Netherlands

Submitted

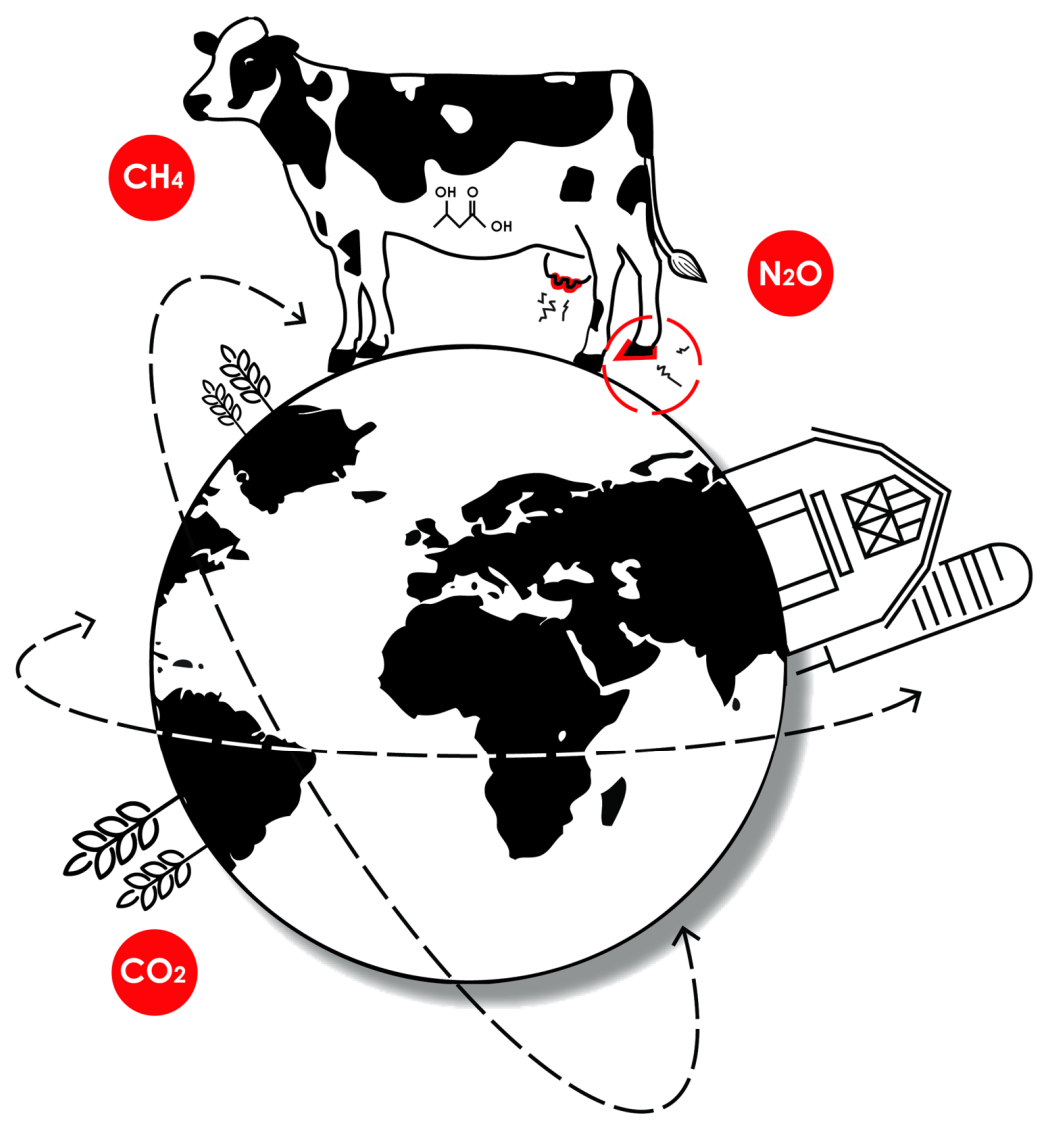


68 | Chapter 4

\section{Abstract}

The dairy sector is an important contributor to greenhouse gas (GHG) emissions. Foot lesions in dairy cows result in production losses and, therefore, might increase GHG emissions per kg milk. The objective of this study was to estimate the impact of foot lesions in dairy cows on GHG emissions. A dynamic stochastic simulation model was developed to estimate dynamics of digital dermatitis (DD), white line disease (WLD), and sole ulcer (SU), and associated production losses within one lactation. Losses included were reduced milk production, prolonged calving interval (CI), and culling. Subsequently, a life cycle assessment was performed to estimate the impact of foot lesions on GHG emissions per ton of fat-and-protein-corrected milk ( $\left.\mathrm{kg} \mathrm{CO}_{2} \mathrm{e} / \mathrm{t} \mathrm{FPCM}\right)$. GHG emissions increased on average by 14 (1.5\%) $\mathrm{kg} \mathrm{CO}_{2} \mathrm{e} / \mathrm{t}$ FPCM per case of foot lesions (i.e. DD, SU, and WLD combined), ranging from $17 \mathrm{~kg} \mathrm{CO}_{2} \mathrm{e} / \mathrm{t} \mathrm{FPCM}$ in parity 1 , to $7 \mathrm{~kg} \mathrm{CO}_{2} \mathrm{e} / \mathrm{t} \mathrm{FPCM}$ in parity 5. Emissions of GHGs increased on average by 4 (0.4\%) $\mathrm{kg} \mathrm{CO}_{2} \mathrm{e} / \mathrm{t}$ FPCM per case of DD, by 39 (4.3\%) $\mathrm{kg} \mathrm{CO}_{2} \mathrm{e} / \mathrm{t}$ FPCM per case of WLD, and by 33 (3.6\%) $\mathrm{kg} \mathrm{CO}_{2} \mathrm{e} / \mathrm{t} \mathrm{FPCM}$ per case of SU. A prolonged CI explained the majority of the increase in GHG emissions for cows with DD, whereas culling was most important for cows with WLD or SU. DD had the lowest impact on GHG emissions, but the highest prevalence, and, therefore, contributed most to the average impact of foot lesions. This study showed that preventing different types of foot lesions can reduce GHG emissions from the dairy sector. The increasing attention for global warming and possible policies to reduce GHG emissions from agriculture might give dairy farmers another incentive to prevent foot lesions. The impact of foot lesions on GHG emissions, however, can vary among dairy farms, because of differences in prevalence of foot lesions and associated production losses, and in farm management (feed and manure). 


\section{Introduction}

Lameness is one of the most important diseases of dairy cows with a prevalence ranging from $0 \%$ to $70 \%$ (Raboisson et al., 2015). Lameness affects the welfare of cows, because it can induce pain (Flower and Weary, 2009). Moreover, lameness reduces milk production by 270 to $574 \mathrm{~kg}$ per cow per lactation, reduces several aspects of reproduction performance (e.g. calving to conception interval, days open, calving interval), and increases the risk of culling (Huxley, 2013).

About 90\% of lameness cases are associated with foot lesions (Murray et al., 1996; Somers and O'Grady, 2015). Foot lesions with the highest prevalence on dairy farms are the infectious digital dermatitis (DD), and the non-infectious white line disease (WLD) and sole ulcer (SU) (Amory et al., 2008; Solano et al., 2016), but this varies between countries, regions, and farming system. DD is an infection of the epidermis of the hoof skin, whereas, WLD is a separation of the wall horn (Amory et al. 2008), and SU is an ulcer in the sole, toe or heel (Somers et al., 2003). Both, WLD and SU, are caused by physical or metabolic disturbance (Bruijnis et al., 2010).

Several studies estimated the economic impact of foot lesions (Bruijnis et al., 2010; Cha et al., 2010; Ettema et al., 2010), but the environmental impact of foot lesions has received little attention so far. One of the most urgent environmental issues is global warming, induced by greenhouse gas (GHG) emissions (Steffen et al., 2015). The livestock sector is responsible for around $14.5 \%$ of the worldwide GHG emissions, and the dairy sector contributes around 30\% of the total (Gerber et al., 2013). Important GHGs in dairy production are carbon dioxide $\left(\mathrm{CO}_{2}\right)$, methane $\left(\mathrm{CH}_{4}\right)$, and nitrous oxide $\left(\mathrm{N}_{2} \mathrm{O}\right)$, which are mainly emitted during feed production, enteric fermentation, and manure management.

Several feeding, breeding and management strategies exist that reduce the GHG impact of milk production. Examples of such feeding strategies are dietary supplementation of extruded linseed or nitrate, or increasing the share of co-products, such as beet tails in diets of dairy cattle (Van Middelaar et al., 2014b; Van Zanten et al., 2014). Examples of breeding strategies that reduce GHG emissions are increasing the milk yield or longevity of dairy cows (Van Middelaar et al., 2014a). Management strategies that reduce milk production losses, such as reducing the prevalence of foot lesions, might also reduce GHG emissions per kg milk. Chen et al. (2016) estimated that lameness (without indicating the causes of lameness) increased GHG emissions per kg milk for a typical Irish grazed grass dairy farm by $0.7 \%$ to $7.8 \%$. The impact on GHG emissions, however, might be affected by the type of farming system. Moreover, Chen et al. (2016) estimated a general effect of lameness, but did not account for different types of foot lesions and parity of cows. Their study was based on reduced milk production and weight losses only, while lameness also has an effect on 
70 | Chapter 4

culling and fertility of the cow (Cramer et al., 2009; Huxley, 2013). All these factors (parity, culling, and fertility) have been demonstrated to affect the impact of diseases on GHG emissions (Mostert et al., 2018) and, therefore, should be included when assessing GHG emissions of foot lesions.

The objective of this study was to estimate the impact foot lesions on GHG emissions. In the estimation, we accounted for different types of foot lesions, and the impact of parity, culling, and cow fertility.

\section{Material and Methods}

A dynamic stochastic simulation model was developed estimate the impact of foot lesions on GHG emissions. We first estimated the dynamics and losses of foot lesions. Subsequently, we used life cycle assessment (LCA) to quantify the GHG impact of foot lesions. Our model was applied to a predefined Dutch dairy farm, with limited grazing $(8 \mathrm{~h} / \mathrm{d})$. The model was developed in $\mathrm{R}$ (R_Core_Team, 2016), and all input values are derived from the literature. Final results presented are based on 100,000 iterations.

\section{Model description}

Each cow receives a parity (1-5+), which is the number of parturitions, based on the average herd composition in the Netherlands (CRV, 2014). Given this pre-defined parity, a cow subsequently receives a milk production, body weight and calving interval (Table 1). Milk production per parity was determined with a normal distribution function (Mostert et al., 2018). A lactation curve was utilized estimate the average daily milk production per cow based on weekly milk records (Wood, 1967). The calving interval (CI) consisted of a lactation period (350-361 d) and a fixed dry period of 60 days $(\mathrm{CRV}, 2014)$. 
Table 1. Input to estimate the impact of digital dermatitis, white line disease, and sole ulcer on greenhouse gas emissions.

\begin{tabular}{|c|c|c|c|c|c|c|}
\hline & Parity 1 & Parity 2 & Parity 3 & Parity 4 & Parity 5+ & Source \\
\hline Cows (\%) & 33 & 27 & 17 & 11 & 12 & CRV (2014) \\
\hline Milk production $(\mathrm{kg})($ mean $/ 305 \mathrm{~d}$ ) & 7535 & 8788 & 9383 & 9493 & 9209 & CRV (2014) \\
\hline Weight cow (kg) & 540 & 595 & 650 & 650 & 650 & CVB (2012) \\
\hline Calving interval (d) & 410 & 413 & 415 & 419 & 421 & CRV (2014) \\
\hline \multicolumn{7}{|l|}{ Digital dermatitis } \\
\hline Probability (\%) & 23.9 & 23.3 & 21.3 & 18.2 & 14.5 & Holzhauer et al. (2006) \\
\hline Occurrence (DIM $\left.{ }^{1}\right)$ & 60 & 60 & 60 & 60 & 60 & Adapted from Amory et al. (2008) \\
\hline Prolonged calving interval (d) & 12 & 12 & 12 & 12 & 12 & Alawneh et al. (2011) \\
\hline Milk loss (kg/lactation) & 17.1 & 17.1 & 17.1 & 17.1 & 17.1 & Relun et al. (2013) \\
\hline \multicolumn{7}{|l|}{ White line disease } \\
\hline Probability (\%) & 4.4 & 4.4 & 4.4 & 4.4 & 4.4 & Solano et al. (2016) \\
\hline Occurrence (DIM) & 120 & 120 & 120 & 120 & 120 & Amory et al. (2008) \\
\hline Prolonged calving interval (d) & 12 & 12 & 12 & 12 & 12 & Alawneh et al. (2011) \\
\hline Milk loss (kg/lactation) & 369 & 369 & 369 & 369 & 369 & Amory et al. (2008) \\
\hline Culling risk (\%) & 34.8 & 34.8 & 34.8 & 34.8 & 34.8 & Adapted from Cramer et al. (2009) \\
\hline \multicolumn{7}{|l|}{ Sole ulcer } \\
\hline Probability (\%) & 3.4 & 3.7 & 4.8 & 7.9 & 12.8 & Holzhauer et al. (2008) \\
\hline Occurrence (DIM) & 150 & 150 & 150 & 150 & 150 & Amory et al. (2008) \\
\hline Prolonged calving interval (d) & 8 & 8 & 8 & 8 & 8 & Hultgren et al. (2004) \\
\hline Milk loss (kg/lactation) & 574 & 574 & 574 & 574 & 574 & Amory et al. (2008) \\
\hline Culling risk (\%) & 29.0 & 29.0 & 29.0 & 29.0 & 29.0 & Adapted from Cramer et al. (2009) \\
\hline
\end{tabular}

Based on the pre-defined parity, a cow has a specific risk of foot lesions (Table 1). The type of foot lesions could be DD, SU, or WLD, which together represent approximately $75 \%$ of all foot lesions cases (Amory et al., 2008; Solano et al., 2016). Because of lack of data and to avoid confounding, a cow was assumed to have only one case of a foot lesion within a lactation. The days in milk of occurrence of foot lesions was fixed and set at 60 for DD, 120 for WLD, and 150 for SU (Amory et al., 2008).

Based on the type of foot lesion, a cow has a reduced milk production (milk loss) (Table 1). A cow with SU or WLD also has an increased culling risk, whereas a cow with DD does not have an increased culling risk (Cramer et al., 2009). A cow with SU or WLD was culled at 262 days in milk, based on Cramer et al. (2009). In that study, cows were culled 157 days after hoof trimming, while the median of days in milk at hoof trimming was 105. The reduction in milk production of a culled cow was estimated until 262 days in milk, because after culling this cow was replaced by an average healthy heifer. Cows with foot lesions have a reduced fertility, dependent on the type of lesion. A 
reduced fertility resulted in a longer lactation period, and, therefore, a prolonged CI (Table 1). The length of the dry period was kept the same. The discrete events on getting a foot lesion and culling were simulated by drawing random numbers from uniform distributions.

\section{Calculation of greenhouse gas emissions}

A life cycle assessment (LCA) was used to estimate the GHG impact of foot lesions. An LCA takes into account the entire life cycle of a product and is a common method to asses GHG emissions (Baumann and Tillmann, 2004). Many studies have used LCA to estimate GHG emissions of milk production, by summing emissions of GHGs along the production chain. Emissions of $\mathrm{CO}_{2}, \mathrm{CH}_{4}$, and $\mathrm{N}_{2} \mathrm{O}$ were estimated from cradle to farm gate for processes along the milk production chain that were affected by foot lesions. Processes included were on and off-farm feed cultivation and processing (including production and use of required inputs), enteric fermentation, and manure management. Emissions associated with medical treatments were assumed to be minor and, therefore, excluded (Hospido and Sonesson, 2005). Emissions of GHGs were estimated for cows with and without foot lesions, and were expressed as $\mathrm{kg} \mathrm{CO}_{2}$ equivalents $\left(\mathrm{CO}_{2} \mathrm{e}\right)$ per ton of fat-andprotein-corrected milk (FPCM). Different GHGs were summed up based on their equivalent factor: 1 for $\mathrm{CO}_{2}, 28$ for biogenic $\mathrm{CH}_{4}, 30$ for fossil $\mathrm{CH}_{4}$, and 265 for $\mathrm{N}_{2} \mathrm{O}$ (100-year time horizon) (Myhre et al., 2013). The impact of foot lesions on GHG emissions was the difference in GHG emissions per ton FPCM between a cow with and without foot lesions. To gain insight in the largest contributors, the impact of foot lesions on GHG emissions was analysed per process (feed production, enteric fermentation, manure management), per parity, per production contributor (reduced milk production, prolonged CI, culling), per type of foot lesion, and the average of the foot lesions combined. The estimation of GHG emissions is described in detail in Mostert et al. (2018) and, therefore, only briefly described below.

Based on national statistics of the Netherlands, a summer (170 d/yr) and winter diet (195 d/yr), were composed (CBS, 2014). Feed ingredients included concentrates and roughage (grass, grass silage, maize silage). Feed intake (kg DM/ cow) was estimated based on the energy content of the diet and the energy requirements of the cow. These energy requirements for maintenance, milk production and pregnancy, and energy requirements for growth in case of parity 1 and 2 were estimated per day (CVB, 2012). Energy requirement for maintenance was assumed to be $6.7 \%$ higher in summer than in winter because of grazing (CVB, 2012).

Emissions of GHGs related to feed production were based on Vellinga et al. (2013) (Table 2). Processes included were the production of inputs (e.g. fertilizers, pesticides, machinery, energy), 
cultivation and harvesting of the crops (including fertilizer application), processing and drying of feed ingredients, and transport between processing steps up to the farm gate. In addition to the processes described above, emissions related to land use ( $\mathrm{Lu}$ ) and land use change (Luc) were included as well (Vellinga et al., 2013). Emissions from enteric fermentation were based on Vellinga et al. (2013), using feed specific emission factors derived from a mechanistic simulation model of rumen fermentation processes (Bannink et al., 2008; Bannink et al., 2010). Emissions from manure were estimated based on national inventory reports and IPCC (2006). Nitrogen (N) excretion, which was used to calculate $\mathrm{N}$ emissions from manure management, was estimated based on $\mathrm{N}$ intake of the cow, $\mathrm{N}$ retention in milk, and in growth of the cow and calf. Direct $\mathrm{N}_{2} \mathrm{O}$ emissions, indirect $\mathrm{N}_{2} \mathrm{O}$ emissions (i.e. $\mathrm{N}_{2} \mathrm{O}$ derived from volatilization of ammonia $\left(\mathrm{NH}_{3}\right.$ ) (De Vries et al., 2011) and nitrogen oxides $\left(\mathrm{NO}_{\mathrm{x}}\right)$ and from leaching of nitrate $\left(\mathrm{NO}_{3}^{-}\right)$) and $\mathrm{CH}_{4}$ emissions from manure in stables and storage, and from manure deposited during grazing were included (De Mol and Hilhorst, 2003; Velthof and Mosquera, 2011; Vonk et al., 2016).

System expansion was applied to account for the production of meat from calves and cows. Consequences of meat production in terms of GHG emissions were based on the so-called avoidedburden method (Guinée et al., 2002; Thomassen et al., 2008). This method assumes that meat from cows replaces alternative products on the market, and therefore subtracts GHG emissions related to the production of those avoided products from the emissions related to dairy production.

Table 2. Greenhouse gas emissions of feed production and land use and land use change (LULuc), enteric methane emissions, and energy and nitrogen content of summer and winter diet.

\begin{tabular}{|c|c|c|}
\hline Input variable ${ }^{1}$ & Summer diet & Winter diet \\
\hline Energy of feed (MJ/ kg DM) & 6.8 & 6.5 \\
\hline Nitrogen content (g /kg DM) & 30.3 & 26.8 \\
\hline Feed production ( $\mathrm{g} \mathrm{CO}_{2} \mathrm{e} / \mathrm{kg} \mathrm{DM}$ ) & 470 & 468 \\
\hline LULuc (g CO ${ }_{2} \mathrm{e} / \mathrm{kg} \mathrm{DM}$ ) & 87 & 94 \\
\hline Enteric methane ( $\left.\mathrm{g} \mathrm{CH}_{4} / \mathrm{kg} \mathrm{DM}\right)$ & 20.9 & 20.5 \\
\hline
\end{tabular}

${ }^{1}$ Vellinga et al. (2013)

Cows that were culled before the end of parity 5 were assumed to be culled too early, resulting in rearing extra heifers. This increases emissions related to non-productive animals. Additional emissions because of culling were estimated as the difference between the emissions of rearing a heifer and the avoided burden of the meat production from that cow. Subsequently, this difference was depreciated over the age of the cow, resulting in a lower impact of culling older cows (Mostert et al., 2018). 


\section{4 | Chapter 4}

\section{Sensitivity analysis}

Sensitivity analyses were performed to analyse the impact of changes in input parameters compared to the reference situation (Table 1). Input parameters were changed based on literature and analysed separately per type of foot lesion. Reduced milk production of SU was increased and decreased by $186 \mathrm{~kg}$ milk per lactation (Amory et al., 2008). Reduced milk production of WLD was increased and decreased by $182 \mathrm{~kg}$ milk per lactation (Amory et al., 2008). Reduced milk production of DD was minor and therefore no sensitivity analyses were performed. The impact of foot lesions on prolonged CI varies a lot in literature. Therefore, prolonged CI was increased to the maximum value found in literature. Prolonged CI of DD, WLD, and SU were increased to 50 days (Hernandez et al., 2005). Culling risk of WLD, and SU were increased and decreased by $50 \%$. The impact of emission factors on GHG emissions was analysed by Mostert et al. (2018) and therefore not performed anymore for this study.

\section{Results}

A case of foot lesions (i.e. DD, SU, and WLD combined) increased GHG emissions on average by $13.6(1.5 \%) \mathrm{kg} \mathrm{CO}_{2} \mathrm{e} / \mathrm{t}$ FPCM. Rearing extra heifers had on average the highest contribution to the increase, followed by emissions from enteric fermentation and feed production (Table 3). The increase of GHG emissions varied from $17 \mathrm{~kg} \mathrm{CO}_{2} \mathrm{e} / \mathrm{t} \mathrm{FPCM}$ in parity 1 to $7 \mathrm{~kg} \mathrm{CO}_{2} \mathrm{e} / \mathrm{t}$ FPCM in parity 5 . Culling contributed most to the impact of foot lesions on GHG emissions. 
Table 3. Greenhouse gas emissions per ton fat-and-protein-corrected milk ( $\left.\mathrm{kg} \mathrm{CO}_{2} \mathrm{e} / \mathrm{t} \mathrm{FPCM}\right)$ for dairy cows with and without foot lesions, and the difference related to feed production, enteric methane land use and land use change (LULuc), manure, avoided burden, and rearing extra heifers.

\begin{tabular}{llll}
\hline & No foot lesions & Foot lesions ${ }^{1}$ & Difference \\
\hline $\mathrm{CO}_{2}$ & & & 0.9 \\
Feed production & 197.3 & 198.2 & 0.3 \\
LULuc & 67.3 & 67.6 & \\
$\mathrm{CH}_{4}$ & & & 0.0 \\
Feed production & 2.8 & 2.8 & 1.9 \\
Enteric fermentation & 428.1 & 430.0 & 0.0 \\
Manure & 44.4 & 44.4 & \\
$\mathrm{~N}_{2} \mathrm{O}$ & & & 0.7 \\
Feed production & 147.1 & 147.7 & 0.3 \\
Manure & 46.3 & 46.6 & 4.1 \\
Total before correction & 933.3 & 937.4 & -0.6 \\
Avoided burden & & -11.0 & 10.0 \\
Rearing extra heifers & & 10.0 & 13.6 \\
Total after correction & 0.0 & 936.4 & \\
\hline
\end{tabular}

${ }^{1}$ Foot lesions are a combination of cows with digital dermatitis, white line disease, and sole ulcer.

2 Emissions are corrected for meat production of the cows based on system expansion. Meat from cows replaces alternative products on the market, and therefore the GHG emissions of meat from cows is equal to the GHG emissions of the alternative product (Mostert et al., 2018).

3 Additional emissions because cows are removed too early resulting in additional GHG emissions for rearing extra replacement heifers.

The increase in GHG emissions varied per type of foot lesion (Table 4). Emissions of GHGs increased on average by 4 (0.4\%) $\mathrm{kg} \mathrm{CO}_{2} \mathrm{e} / \mathrm{t}$ FPCM per case of DD, with a range between $3 \mathrm{~kg}$ $\mathrm{CO}_{2} \mathrm{e} / \mathrm{t}$ FPCM and $4 \mathrm{~kg} \mathrm{CO}_{2} \mathrm{e} / \mathrm{t}$ FPCM (5-95 percentiles). Parity had no effect on the impact of DD on GHG emissions. A prolonged CI contributed most to the impact of DD on GHG emissions.

Emissions of GHGs increased on average by 39 (4.3\%) $\mathrm{kg} \mathrm{CO}_{2} \mathrm{e} / \mathrm{t}$ FPCM per case of WLD, with a range between $11 \mathrm{~kg} \mathrm{CO}_{2} \mathrm{e} / \mathrm{t}$ FPCM and $140 \mathrm{~kg} \mathrm{CO}_{2} \mathrm{e} / \mathrm{t}$ FPCM (5-95 percentiles). The increase in GHG emissions varied from $59 \mathrm{~kg} \mathrm{CO} 2 \mathrm{e} / \mathrm{t} \mathrm{FPCM}$ in parity 1 , to $6 \mathrm{~kg} \mathrm{CO}_{2} \mathrm{e} / \mathrm{t} \mathrm{FPCM}$ in parity 5 . Culling contributed most to the impact of WLD on GHG emissions.

Emissions of GHGs increased on average by 33 (3.6\%) $\mathrm{kg} \mathrm{CO}_{2} \mathrm{e} / \mathrm{t}$ FPCM per case of SU, with a range between $-6 \mathrm{~kg} \mathrm{CO}_{2} \mathrm{e} / \mathrm{t}$ FPCM and $139 \mathrm{~kg} \mathrm{CO}_{2} \mathrm{e} / \mathrm{t}$ FPCM (5-95 percentiles). The increase in GHG emissions varied from $60 \mathrm{~kg} \mathrm{CO}_{2} \mathrm{e} / \mathrm{t}$ FPCM in parity 1 , to $11 \mathrm{~kg} \mathrm{CO}_{2} \mathrm{e} / \mathrm{t}$ FPCM in parity 5 . The main production contributors of SU were culling and reduced milk production. 
Table 4. Average increase (5-95 percentiles) in greenhouse gas emissions per ton fat-and-proteincorrected milk ( $\mathrm{kg} \mathrm{CO}_{2} \mathrm{e} / \mathrm{t}$ FPCM) per parity due to digital dermatitis (DD), white line disease (WLD), sole ulcer (SU), and combinations of the three foot lesions related to reduced milk production, prolonged calving interval, culling, and avoided burden.

\begin{tabular}{|c|c|c|c|c|c|c|}
\hline Contributor & Parity 1 & Parity 2 & Parity 3 & Parity 4 & Parity $5+$ & Average $^{1}$ \\
\hline \multicolumn{7}{|l|}{ DD } \\
\hline Reduced milk production & $1(1-1)$ & $1(0-1)$ & $0(0-1)$ & $0(0-1)$ & $0(0-1)$ & $1(0-1)$ \\
\hline Prolonged calving interval & $2(2-2)$ & $3(3-4)$ & $3(3-3)$ & $3(3-3)$ & $3(3-4)$ & $3(2-4)$ \\
\hline Culling & $0(0-0)$ & $0(0-0)$ & $0(0-0)$ & $0(0-0)$ & $0(0-0)$ & $0(0-0)$ \\
\hline Avoided burden ${ }^{2}$ & $0(0-0)$ & $0(0-0)$ & $0(0-0)$ & $0(0-0)$ & $0(0-0)$ & $0(0-0)$ \\
\hline Total & $3(3-4)$ & $4(4-5)$ & $3(3-4)$ & $3(3-4)$ & $4(3-4)$ & $4(3-4)$ \\
\hline \multicolumn{7}{|l|}{ WLD } \\
\hline Reduced milk production & $14(9-19)$ & $11(7-14)$ & $9(6-12)$ & $9(6-12)$ & $9(6-13)$ & $11(6-17)$ \\
\hline Prolonged calving interval & $1(0-2)$ & $2(0-4)$ & $2(0-3)$ & $2(0-3)$ & $2(0-4)$ & $2(0-3)$ \\
\hline Culling & $45(0-136)$ & $35(0-102)$ & $23(0-74)$ & $12(0-39)$ & $-2(-6-0)$ & $29(0-131)$ \\
\hline Avoided burden & $-1(-3-0)$ & $-1(-3-0)$ & $-4(-13-0)$ & $-4(-13-0)$ & $-4(-14-0)$ & $-2(-12-0)$ \\
\hline Total & $59(14-143)$ & $46(12-107)$ & $30(11-67)$ & $18(11-33)$ & $6(-18-16)$ & $39(11-140)$ \\
\hline \multicolumn{7}{|l|}{ SU } \\
\hline Reduced milk production & $23(14-31)$ & $17(11-23)$ & $15(9-20)$ & $14(9-19)$ & $15(9-21)$ & $17(9-26)$ \\
\hline Prolonged calving interval & $1(0-1)$ & $1(0-2)$ & $1(0-2)$ & $1(0-2)$ & $1(0-2)$ & $1(0-2)$ \\
\hline Culling & $39(0-136)$ & $29(0-101)$ & $20(0-73)$ & $9(0-38)$ & $-2(-15-0)$ & $17(-5-123)$ \\
\hline Avoided burden & $-1(-3--1)$ & $-1(-3--1)$ & $-4(-13-0)$ & $-3(-13-0)$ & $-3(-12-0)$ & $-3(-12-0)$ \\
\hline Total & $60(21-147)$ & $46(17-109)$ & $32(15-70)$ & $21(15-35)$ & $11(-15-23)$ & $33(-6-139)$ \\
\hline \multicolumn{7}{|l|}{ Foot lesions ${ }^{3}$} \\
\hline Reduced milk production & $5(1-24)$ & $4(0-18)$ & $4(0-16)$ & $5(0-17)$ & $8(0-19)$ & $5(0-19)$ \\
\hline Prolonged calving interval & $2(0-2)$ & $3(0-4)$ & $3(0-3)$ & $2(0-3)$ & $2(0-3)$ & $2(0-3)$ \\
\hline Culling & $10(0-128)$ & $8(0-96)$ & $6(0-69)$ & $4(0-35)$ & $-1(-11-0)$ & $7(0-76)$ \\
\hline Avoided burden & $0(-2-0)$ & $0(-2-0)$ & $-1(-13-0)$ & $-1(-12-0)$ & $-2(-12-0)$ & $-1(-3-0)$ \\
\hline Total & 17 (3-139) & $15(4-104)$ & $12(3-64)$ & $10(3-31)$ & $7(-13-21)$ & $14(3-71)$ \\
\hline
\end{tabular}

${ }^{1} \mathrm{~A}$ weighted average for all parities was taken which was based on the composition of an average Dutch dairy herd

${ }^{2}$ Emissions are corrected for meat production of the cows based on system expansion. Meat from cows replaces alternative products on the market, and therefore the GHG emissions of meat from cows is equal to the GHG emissions of the alternative product (Mostert et al., 2018)

${ }^{3}$ Foot lesions are a combination of cows with digital dermatitis, white line disease, and sole ulcer. 


\section{Sensitivity analysis}

Results of changing the input parameters are shown in Figure 1. All production parameters increased or decreased GHG emissions by more than $17 \%$ and varied per type of foot lesion. Culling had the highest impact on the increase or decrease of GHG emissions of WLD, whereas increased milk losses had the highest impact on the increase of GHG emissions of SU. Increasing prolonged CI increased GHG emissions of SU, WLD, and DD by respectively 17\%, 25\%, and 291\% (not shown in Figure 1).

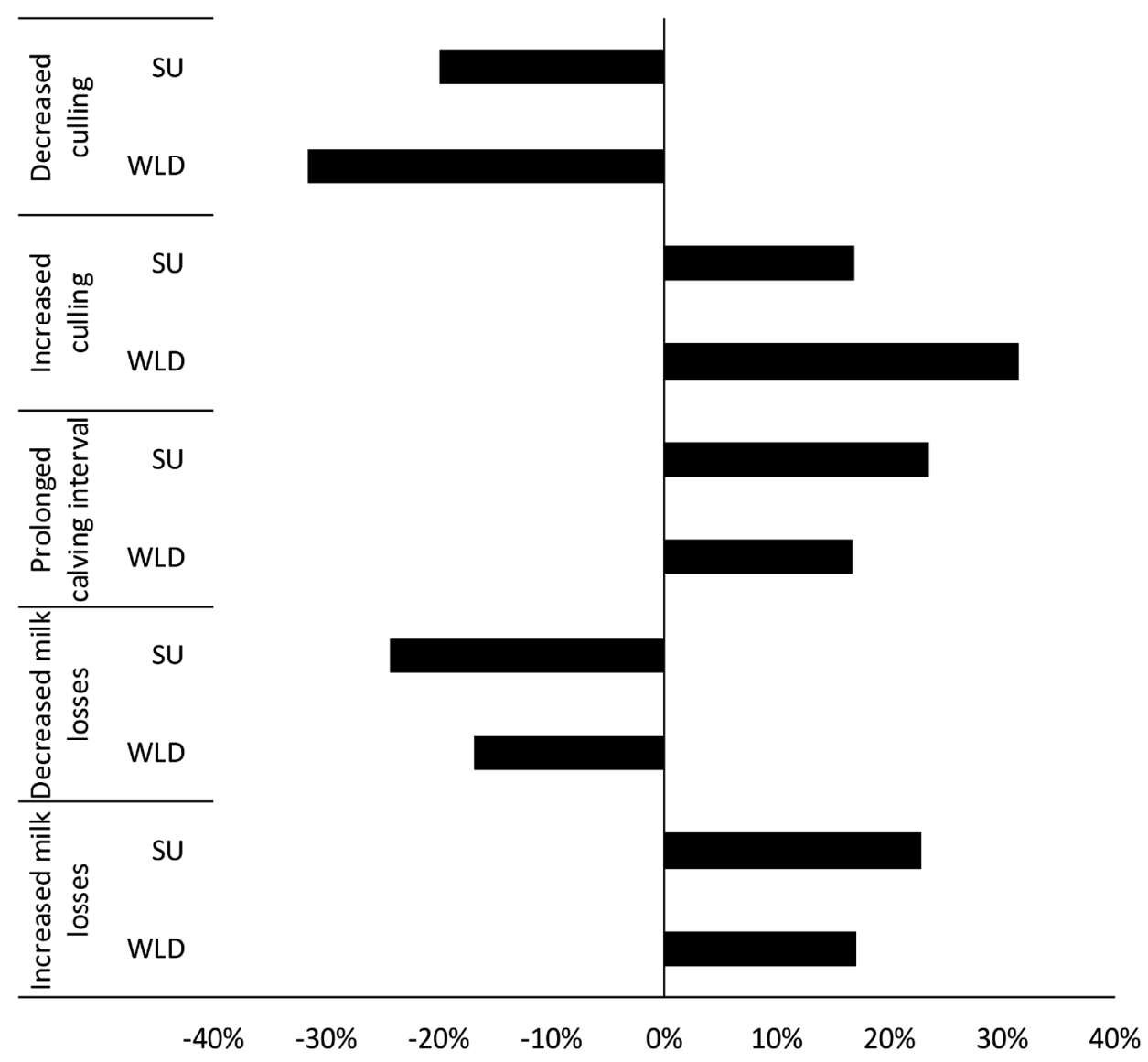

Figure 1. Results from the sensitivity analyses showing the effect (\%) of a change in production parameters of white line disease (WLD) and sole ulcer (SU) on greenhouse gas emissions per ton fat-and-protein-corrected milk ( $\left.\mathrm{kg} \mathrm{CO}_{2} \mathrm{e} / \mathrm{t} \mathrm{FPCM}\right)$ compared to the reference situation. 


\section{Discussion}

This study showed that per case of foot lesions in dairy cows GHG emissions increased on average by 1.5\%. Chen et al. (2016) found an increase in GHG emissions between $0.7 \%$ and $7.8 \%$, depending on milk losses and prevalence of lameness at herd level. Differences in GHG impact between our study and Chen et al. (2016) can be explained by three main factors. First, Chen et al. (2016) estimated the impact of overall lameness at herd level and did not assess individual cases or differentiate between different types of foot lesions. Lameness is a general term in literature and can include different types of foot lesions. The impact on production losses varies per type of foot lesion, and therefore including data about the overall impact of lameness on production losses to estimate GHG emissions may result in an over- or underestimation. Our study showed that GHG emissions increased between $0.4 \%$ and $4.3 \%$ depending on the type of foot lesion. Furthermore, DD had the lowest impact on GHG emissions, but the highest prevalence and, therefore, contributed most to the average impact of the three foot lesions combined. Prevalence varies per type of foot lesion and per farm and therefore the impact on GHG emissions per type of foot lesion is more informative for farmers than the average impact. Second, type of production system and consequently production input were different. Milk production in Chen et al. (2016) was much lower (5,480 kg milk per cow/year) than in our study, and therefore a kg milk loss had a higher impact than in our study. Third, the maximum reduced milk production because of lameness was higher $(1.8 \mathrm{~kg} /$ day) than in our study. Because of the latter two factors, the proportion of reduced milk from the total amount of milk was higher in Chen et al. (2016) than in our study. This results in a lower feed efficiency and higher energy requirement per $\mathrm{kg}$ of milk produced, resulting in a higher GHG impact of reduced milk production.

The inclusion of different production contributors and parity of cows demonstrated to be relevant and can result in better decision making for farmers. Our study showed that the impact of WLD and SU on GHG emissions was higher for cows in parity 1 (6o and $58 \mathrm{~kg} \mathrm{CO}_{2} \mathrm{e} / \mathrm{t} \mathrm{FPCM}$ ) than for cows in parity 5 ( 5 and $11 \mathrm{~kg} \mathrm{CO}_{2} \mathrm{e} / \mathrm{t}$ FPCM). This was especially due to the relatively higher impact of culling of cows with a low parity, because rearing a heifer results in GHG emissions without milk output. The contribution of GHG emissions from rearing a heifer per unit milk is lower for cows with a higher parity, because they already have produced more milk in their life. Reduced milk production in parity 5 increased GHG emissions by $1.6 \%$ for cows with SU and by $1.0 \%$ for cows with WLD. Preventing these types of foot lesions in cows with a high parity, therefore, can reduce GHG emissions as well. Other studies showed that other diseases in dairy cows also increase GHG emissions and that improving health of dairy cows can reduce the impact of the dairy sector on 
GHG emissions. Mostert et al. (2018), for example, showed that a case of subclinical ketosis in dairy cows increased GHG emissions by $2.3 \%$. Hospido and Sonesson (2005) showed that reducing subclinical mastitis by $7 \%$ and clinical mastitis by $18 \%$ reduced GHG emissions by $2.5 \%$ at herd level. The average impact of foot lesions is lower, but varies per type of foot lesions.

Many studies analysed the impact of lameness on milk production and reproduction. The definition of lameness and the analyses of losses differ per study resulting in a wide range of production losses because of different types of foot lesions. Only a few studies estimated reduced milk production specifically attributed to foot lesions, resulting in assumptions or extrapolating reduced milk production from cows with lameness. This is for example well shown in reduced milk production used in economic estimations of DD. In Bruijnis et al. (2010), cows with DD had a reduced milk production of $8 \%$ per month. In Cha et al. (2010) multiparous cows with DD had a reduced milk production of $0.91 \mathrm{~kg} /$ day in the first month and $0.76 \mathrm{~kg}$ /day in the following months, and in Ettema et al. (2010) cows with DD had a reduced milk production of $0.5 \%$ during the entire lactation. Differences in reduced milk production and methodology to estimate costs of DD result in different conclusions. Reduced milk production because of foot lesions in our study was based on data of a few studies about these foot lesions. No data, however, were available to include parity specific losses. The ranges of reduced milk production found in literature were included in the sensitivity analyses showing that the amount of reduced milk production is an important contributor to the impact of foot lesions on GHG emissions. Therefore, better data about reduced milk production of specific foot lesions could improve the estimation of the impact of foot lesions on GHG emissions.

Reproduction was included by extending the calving interval of the cow. No data were available about cows that were culled because of reduced reproduction, and therefore the impact of foot lesions on GHG emissions might be underestimated.

Foot lesions can also be subclinical and one type of foot lesion might increase the risk of other foot lesions. Because of lack of data and to avoid confounding, these relations were not included in the analyses, implying that current GHG impact estimates might be underestimated. To show the full potential of reducing GHG emissions for a specific dairy farm, farm specific data are needed about reduced milk production, reproductive performance, culling, and different types of foot lesions, including subclinical ones. Moreover, farm specific data about feed and manure management could further improve the estimation. 
8o $\mid$ Chapter 4

GHG emissions of dairy cows could also be reduced by dietary supplementation of extruded linseed (9 $\mathrm{kg} \mathrm{CO}_{2} \mathrm{e} / \mathrm{t} \mathrm{FPCM}$ ), or nitrate (32 $\mathrm{kg} \mathrm{CO}_{2} \mathrm{e} / \mathrm{t} \mathrm{FPCM}$ ), or by reducing the maturity stage of grass and grass silage (11 $\mathrm{kg} \mathrm{CO}_{2} \mathrm{e} / \mathrm{t}$ FPCM) (Van Middelaar et al., 2014b). These strategies can have a higher reduction in GHG emissions, but are not costs-effective. Increasing milk yield with 698 $\mathrm{kg}$ /year per cow and longevity with 270 days per cow decreased GHG emissions by respectively 27 and $23 \mathrm{~kg} \mathrm{CO}_{2} \mathrm{e} / \mathrm{t}$ FPCM and were costs-effective (Van Middelaar et al., 2014a). Preventing foot lesions can contribute to these aspects.

Costs for lameness are estimated at $\$ 75$ per cow per year on herd level (Bruijnis et al., 2010), whereas costs per case are estimated at $\$ 216$ for sole ulcer, and $\$ 133$ for digital dermatitis (Cha et al., 2010).

Dairy cow foot health can be improved by e.g. improvements in flooring, lying surface, hygiene, summer pasturing, and increasing frequency of foot trimming and footbaths (Bruijnis et al., 2013b; De Vries et al., 2015). Improving lying surface (bedding and mattress) and including an extra foot trimming intervention at drying off were costs-effective (Bruijnis et al., 2013b). The effectiveness of these strategies on GHG emissions is unknown. Preventing a case of SU and WLD can have a higher reduction in GHG emissions than DD. Although reducing DD might have a minor impact on reducing GHG emissions, DD can be very painful for a cow (Bruijnis et al., 2012), and therefore still needs attention from an animal welfare perspective.

Preventing one type of foot lesion can also reduce other types of foot lesions. Preventing foot lesions, such as interdigital dermatitis/heel horn erosion, interdigital hyperplasia, and interdigital phlegmon, reduced prevalence of DD by 42\% (Holzhauer et al., 2006). Moreover, Holzhauer et al. (2008) also found a strong relation between other non-infectious foot lesions and SU. Because of the strong interactions of different types of foot lesions, prevention should focus on all type of foot lesions (Holzhauer et al., 2006). Lower prevalence of foot lesions, however, appears to be hard to realize in practice and most farmers seem to be satisfied with the foot health status at their farm (Bruijnis et al., 2013a). Possible barriers for farmers to take action are labour efficiency and the long interval for seeing an improvement after an action (Bruijnis et al., 2013a). The increasing attention for global warming and possible policies to also reduce GHG emissions from agriculture might give farmers another incentive to prevent foot lesions on their dairy farms. 


\section{Conclusions}

Foot lesions, i.e. DD, WLD and SU combined, increased GHG emissions on average by 13.6 (1.5\%) $\mathrm{kg} \mathrm{CO}_{2} \mathrm{e} / \mathrm{t}$ FPCM. Culling contributed most to the impact of foot lesions on GHG emissions. The impact of foot lesions on GHG emissions was lower for cows with a higher parity. Emissions of GHGs increased on average by $4 \mathrm{~kg} \mathrm{CO}_{2} \mathrm{e} / \mathrm{t}$ FPCM per case of DD, with a range between 3 and 4 $\mathrm{kg} \mathrm{CO} 2 \mathrm{e} / \mathrm{t}$ FPCM (5-95 percentiles). Emissions of GHGs increased on average by $39 \mathrm{~kg} \mathrm{CO}_{2} \mathrm{e} / \mathrm{t}$ FPCM per case of WLD, with a range between 11 and $140 \mathrm{~kg} \mathrm{CO}_{2} \mathrm{e} / \mathrm{t}$ FPCM (5-95 percentiles). Emissions of GHGs increased on average by $33 \mathrm{~kg} \mathrm{CO}_{2} \mathrm{e} / \mathrm{t}$ FPCM per case of SU, with a range between -6 and $139 \mathrm{~kg} \mathrm{CO}_{2} \mathrm{e} / \mathrm{t} \mathrm{FPCM}$ (5-95 percentiles). Prevalence of type of foot lesions varies per farm and therefore average impact of lameness on GHG emissions is less informative for farmers than impact per type of foot lesion. 


\section{References}

Alawneh, J.I., Laven, R.A., Stevenson, M.A., 2011. The effect of lameness on the fertility of dairy cattle in a seasonally breeding pasture-based system. J. Dairy Sci. 94, 5487-5493.

Amory, J.R., Barker, Z.E., Wright, J.L., Mason, S.A., Blowey, R.W., Green, L.E., 2008. Associations between sole ulcer, white line disease and digital dermatitis and the milk yield of 1824 dairy cows on 30 dairy cow farms in England and Wales from February 2003-November 2004. Prev. Vet. Med. 83, 381-391.

Bannink, A., France, J., Lopez, S., Gerrits, W.J.J., Kebreab, E., Tamminga, S., Dijkstra, J., 2008. Modelling the implications of feeding strategy on rumen fermentation and functioning of the rumen wall. Anim. Feed Sci. Technol. 143, 3-26.

Bannink, A., Smits, M.C.J., Kebreab, E., Mills, J.A.N., Ellis, J.L., Klop, A., France, J., Dijkstra, J., 2010. Simulating the effects of grassland management and grass ensiling on methane emission from lactating cows. J. Agric. Sci. 148, 55-72.

Baumann, H., Tillmann, A., 2004. The hitch hiker's guide to LCA An orientation in life cycle assessment methodology and application. Studentlitteratur AB, Lund, Sweden.

Bruijnis, M., Hogeveen, H., Garforth, C., Stassen, E., 2013a. Dairy farmers' attitudes and intentions towards improving dairy cow foot health. Livest. Sci. 155, 103-113.

Bruijnis, M.R.N., Beerda, B., Hogeveen, H., Stassen, E.N., 2012. Assessing the welfare impact of foot disorders in dairy cattle by a modeling approach. Animal 6, 962-970.

Bruijnis, M.R.N., Hogeveen, H., Stassen, E.N., 2010. Assessing economic consequences of foot disorders in dairy cattle using a dynamic stochastic simulation model. J. Dairy Sci. 93, 2419-2432.

Bruijnis, M.R.N., Hogeveen, H., Stassen, E.N., 2013b. Measures to improve dairy cow foot health: consequences for farmer income and dairy cow welfare. animal 7, 167-175.

CBS 2014. Centraal Bureau voor de Statistiek. Dierlijke mest en mineralen 2013 (Animal manure and minerals 2013). CBS, Den Haag, the Netherlands.

Cha, E., Hertl, J.A., Bar, D., Gröhn, Y.T., 2010. The cost of different types of lameness in dairy cows calculated by dynamic programming. Prev. Vet. Med. 97, 1-8.

Chen, W., White, E., Holden, N.M., 2016. The effect of lameness on the environmental performance of milk production by rotational grazing. J. Environ. Manage. 172, 143-150.

Cramer, G., Lissemore, K.D., Guard, C.L., Leslie, K.E., Kelton, D.F., 2009. The association between foot lesions and culling risk in Ontario Holstein cows. J. Dairy Sci. 92, 2572-2579.

CRV 2014. International Dutch cattle improvement co-operative. Jaarstatistieken 2014 voor Nederland (Annual statistics 2014). CRV, Arnhem, the Netherlands.

CVB 2012. Centraal Veevoederbureau. Tabellenboek veevoeding 2012, voedernormen landbouwhuisdieren en voederwaarde veevoeders (Composition and nutritional values of feedstuffs and requirement values), CVB-reeks nr.50, August 2012. Productschap Diervoeder, Den Haag, the Netherlands. 
De Mol R.M., Hilhorst M.A., 2003. Emissions of methane, nitrous oxide and ammonia from production, storage and transport of manure. Institute of Agricultural and Environmental Engineering, Wageningen, the Netherlands.

De Vries, M., Bokkers, E.A.M., van Reenen, C.G., Engel, B., van Schaik, G., Dijkstra, T., de Boer, I.J.M., 2015. Housing and management factors associated with indicators of dairy cattle welfare. Prev. Vet. Med. 118, 80-92.

De Vries J.W., Hoeksma P., Groenestein C.M., 2011. LevensCyclusAnalyse (LCA) pilot mineralenconcentraten. Wageningen UR Livestock Research, Wageningen, the Netherlands.

Ettema, J., Østergaard, S., Kristensen, A.R., 2010. Modelling the economic impact of three lameness causing diseases using herd and cow level evidence. Prev. Vet. Med. 95, 64-73.

Flower, F.C., Weary, D.M., 2009. Gait assessment in dairy cattle. animal 3, 87-95.

Gerber, P.J., Steinfeld, H., Henderson, B., Mottet, A., Opio, C., Dijkman, J., Falcucci, A., Tempio, G., 2013. Tackling climate change through livestock - A global assessment of emissions and mitigation opportunities. Food and Agriculture Organization of the United Nations (FAO),

Guinée, J., Gorrée, M., Heijungs, R., Huppes, G., Kleijn, R., de Koning, A., van Oers, L., Wegener Sleeswijk, A., Suh, S., Udo de Haes, H., de Bruijn, H., van Duin, R., Huijbregts, M., Lindeijer, E., Roorda, A., van der Ven, B., Weidema, B., 2002. Handbook on life cycle assessment. Operational guide to the ISO standards. Kluwer, Leiden, the Netherlands.

Hernandez, J.A., Garbarino, E.J., Shearer, J.K., Risco, C.A., Thatcher, W.W., 2005. Comparison of the calving-to-conception interval in dairy cows with different degrees of lameness during the prebreeding postpartum period. J. Am. Vet. Med. Assoc. 227, 1284-1291.

Holzhauer, M., Hardenberg, C., Bartels, C.J.M., 2008. Herd and cow-level prevalence of sole ulcers in The Netherlands and associated-risk factors. Prev. Vet. Med. 85, 125-135.

Holzhauer, M., Hardenberg, C., Bartels, C.J.M., Frankena, K., 2006. Herd- and Cow-Level Prevalence of Digital Dermatitis in The Netherlands and Associated Risk Factors. J. Dairy Sci. 89, 580-588.

Hospido, A., Sonesson, U., 2005. The environmental impact of mastitis: a case study of dairy herds. Sci. Total Environ. 343, 71-82.

Hultgren, J., Manske, T., Bergsten, C., 2004. Associations of sole ulcer at claw trimming with reproductive performance, udder health, milk yield, and culling in Swedish dairy cattle. Prev. Vet. Med. 62, 233-251.

Huxley, J.N., 2013. Impact of lameness and claw lesions in cows on health and production. Livest. Sci. 156, 64-70.

Mostert, P.F., van Middelaar, C.E., Bokkers, E.A.M., de Boer, I.J.M., 2018. The impact of subclinical ketosis in dairy cows on greenhouse gas emissions of milk production. J Clean Prod. 171, 773-782. 
Murray, R.D., Downham, D.Y., Clarkson, M.J., Faull, W.B., Hughes, J.W., Manson, F.J., Merritt, J.B., Russell, W.B., Sutherst, J.E., Ward, W.R., 1996. Epidemiology of lameness in dairy cattle: Description and analysis of foot lesions. Vet. Rec. 138, 586-591.

Myhre, G., Shindell, D., Bréon, F.-M., Collins, W., Fuglestvedt, J., J. Huang, D.K., Lamarque, J.F., Lee, D., Mendoza, B., Nakajima, T., Robock, A., Stephens, G., Takemura, T., H. Zhang, 2013. Anthropogenic and Natural Radiative Forcing. In: Climate Change 2013: The Physical Science Basis. Contribution of Working Group I to the Fifth Assessment Report of the Intergovernmental Panel on Climate Change [Stocker, T.F., D. Qin, G.-K. Plattner, M. Tignor, S.K. Allen, J. Boschung, A. Nauels, Y. Xia, V. Bex and P.M. Midgley (eds.)]. Cambridge University Press, Cambridge, United Kingdom and New York, NY, USA.

IPCC, 2006. Intergovernmental Panel on Climate Change. Guidelines for national greenhouse gas inventories, in: H.S. Eggleston, L. Buendia, K. Miwa, T. Ngara, K. Tanabe (Eds.), Agriculture, Forestry and Other Land Use, vol. 4, IGES, Japan (2006).

R_Core_Team, 2016. R: A language and environment for statistical computing. R Foundation for Statistical Computing, Vienna, Austria.

Raboisson, D., Mounié, M., Khenifar, E., Maigné, E., 2015. The economic impact of subclinical ketosis at the farm level: Tackling the challenge of over-estimation due to multiple interactions. Prev. Vet. Med. 122, 417-425.

Relun, A., Lehebel, A., Chesnin, A., Guatteo, R., Bareille, N., 2013. Association between digital dermatitis lesions and test-day milk yield of Holstein cows from 41 French dairy farms. J. Dairy Sci. 96, 2190-2200.

Solano, L., Barkema, H.W., Mason, S., Pajor, E.A., LeBlanc, S.J., Orsel, K., 2016. Prevalence and distribution of foot lesions in dairy cattle in Alberta, Canada. J. Dairy Sci. 99, 6828-6841.

Somers, J.G.C.J., Frankena, K., Noordhuizen-Stassen, E.N., Metz, J.H.M., 2003. Prevalence of Claw Disorders in Dutch Dairy Cows Exposed to Several Floor Systems. J. Dairy Sci. 86, 2082-2093.

Somers, J., O'Grady, L., 2015. Foot lesions in lame cows on 10 dairy farms in Ireland. Ir. Vet. J. 68. Steffen, W., Richardson, K., Rockström, J., Cornell, S.E., Fetzer, I., Bennett, E.M., Biggs, R., Carpenter, S.R., de Vries, W., de Wit, C.A., Folke, C., Gerten, D., Heinke, J., Mace, G.M., Persson, L.M., Ramanathan, V., Reyers, B., Sörlin, S., 2015. Planetary boundaries: Guiding human development on a changing planet. Science 347.

Thomassen, M.A., Dalgaard, R., Heijungs, R., de Boer, I., 2008. Attributional and consequential LCA of milk production. Int. J. Life Cycle Assess. 13, 339-349.

Van Middelaar, C.E., Berentsen, P.B.M., Dijkstra, J., van Arendonk, J.A.M., de Boer, I.J.M., 2014a. Methods to determine the relative value of genetic traits in dairy cows to reduce greenhouse gas emissions along the chain. J. Dairy Sci. 97, 5191-5205.

Van Middelaar, C.E., Dijkstra, J., Berentsen, P.B.M., De Boer, I.J.M., 2014b. Cost-effectiveness of feeding strategies to reduce greenhouse gas emissions from dairy farming. J. Dairy Sci. 97, 2427-2439. 
Van Zanten, H.H.E., Mollenhorst, H., De Vries, J.W., Van Middelaar, C.E., Van Kernebeek, H.R.J., De Boer, I.J.M., 2014. Assessing environmental consequences of using co-products in animal feed. Int. J. Life Cycle Assess. 19, 79-88.

Vellinga T.V., Blonk H., Marinussen M., Van Zeist W.J., De Boer I.J.M., 2013. Methodology used in feedprint: a tool quantifying greenhouse gas emissions of feed production and utilization. Wageningen UR Livestock research, Lelystad, the Netherlands.

Velthof, G.L., Mosquera, J., 2011. Calculation of nitrous oxide emission from agriculture in the Netherlands. Alterra, Wageningen, the Netherlands.

Vonk, J., Bannink, A., van Bruggen, C., Groenestein, C.M., Huijsmans, J.F.M., van der Kolk, J.W.H., Luesink, H.H., Oude Voshaar, S.V., van der Sluis, S.M., Velthof, G.L., 2016. Methodology for estimating emissions from agriculture in the Netherlands Calculations of $\mathrm{CH}_{4}, \mathrm{NH}_{3}, \mathrm{~N} 2 \mathrm{O}, \mathrm{NOx}, \mathrm{PM} 10, \mathrm{PM} 2.5$ and $\mathrm{CO}_{2}$ with the National Emission Model for Agriculture (NEMA). The Statutory Research Tasks Unit for Nature and the Environment (WOT Natuur \& Milieu), Wageningen, the Netherlands.

Wood, P.D.P., 1967. Algebraic model of the lactation curve in cattle. Nature 216, 164-165. 



\section{Chapter 5}

Estimating the economic impact of subclinical ketosis in dairy cattle using a dynamic stochastic simulation model

P.F. Mostert ${ }^{1}$, E.A.M. Bokkers ${ }^{1}$, C.E. van Middelaar ${ }^{1}$, H. Hogeveen ${ }^{2}$ and I.J.M. de Boer ${ }^{1}$

${ }^{1}$ Animal Production Systems group, Wageningen University \& Research, Wageningen, the Netherlands

${ }^{2}$ Business Economics group, Wageningen University \& Research, Wageningen, the Netherlands

Animal 12 (2018) 145-154.

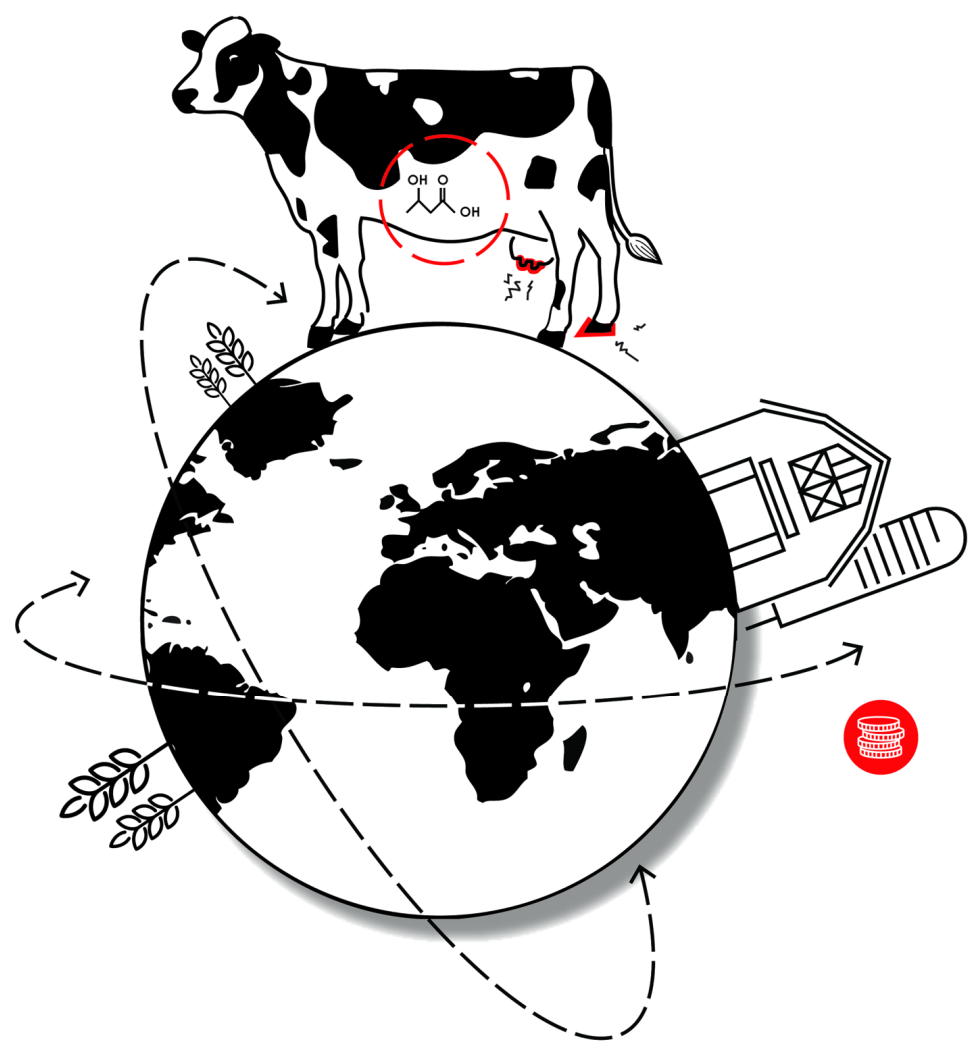


$\mathbf{8 8} \mid$ Chapter 5

\begin{abstract}
The objective of this study was to estimate the economic impact of subclinical ketosis (SCK) in dairy cows. This metabolic disorder occurs in the period around calving and is associated with an increased risk of other diseases. Therefore, SCK affects farm productivity and profitability. Estimating the economic impact of SCK may make farmers more aware of this problem, and can improve their decision-making regarding interventions to reduce SCK. We developed a dynamic stochastic simulation model that enables estimating the economic impact of SCK and related diseases (i.e. mastitis, metritis, displaced abomasum, lameness, and clinical ketosis) occurring during the first 30 days after calving. This model, which was applied to a typical Dutch dairy herd, groups cows according to their parity ( 1 to $5^{+}$), and simulates the dynamics of SCK and related diseases, and milk production per cow during one lactation. The economic impact of SCK and related diseases resulted from a reduced milk production, discarded milk, treatment costs, costs from a prolonged calving interval, and removal (culling or dying) of cows. The total costs of SCK were $€ 130$ per case per year, with a range between $€_{39}$ and $€_{348}$ (5-95 percentiles). The total costs of SCK per case per year, moreover, increased from $€ 83$ per year in parity 1 , to $€ 175$ in parity 3 . Most cows with SCK, however, had SCK only (61\%), and costs were $€ 58$ per case per year. Total costs of SCK per case per year resulted for $36 \%$ from a prolonged calving interval, $24 \%$ from reduced milk production, $19 \%$ from treatment, $14 \%$ from discarded milk, and $6 \%$ from removal. Results of the sensitivity analysis showed that the disease incidence, removal risk, relations of SCK with other diseases, and prices of milk resulted in a high variation of costs of SCK. The costs of SCK, therefore, might differ per farm because of farm specific circumstances. Improving data collection on the incidence of SCK and related diseases, and on consequences of diseases can further improve economic estimations.
\end{abstract}




\section{Implications}

Subclinical ketosis (SCK) in dairy cows reduces the productivity and therefore the efficiency of milk production and the profitability of the dairy farm. Estimating the economic impact of SCK may make farmers more aware of this problem, and can improve their decision-making regarding interventions to reduce SCK. The total costs of SCK in dairy cows were $€ 130$ per case per year, and varied from $€ 83$ in parity 1 to $€ 175$ in parity 3 . Costs were $36 \%$ from a prolonged calving interval, $24 \%$ from reduced milk production, $19 \%$ from treatment, $14 \%$ from discarded milk, and $6 \%$ from removal. 
90 | Chapter 5

\section{Introduction}

Subclinical ketosis (SCK) in dairy cows is a metabolic disorder that occurs in the period around calving. In this period, the energy requirement can exceed the energy intake, which results in a negative energy balance (NEB) (Van Knegsel et al., 2005). The adaptation of cows to an NEB is reflected in the concentration of non-esterified fatty acids and beta-hydroxybutyrate (BHBA) in the blood (Leblanc, 2010). Most studies assumed that cows have SCK if the BHBA level is higher than 1.2-1.4 mmol BHBA/l blood, but not have clinical signs of ketosis (Raboisson et al., 2014). The average prevalence of SCK in dairy cows obtained from several European countries (Italy, Croatia, Hungary, Poland, Serbia, Slovenia, Portugal, Spain, Germany, Turkey, France, the Netherlands, United kingdom) ranges from 11\% to 49\% (Berge and Vertenten, 2014; Suthar et al., 2013).

Several studies showed that SCK can have a negative impact on milk production, reproduction and removal (culling or dying) of cows (McArt et al., 2012; Raboisson et al., 2014; Walsh et al., 2007). Moreover, SCK is associated with an increased risk of, for example, displaced abomasum, metritis, mastitis, lameness, and clinical ketosis (Berge and Vertenten, 2014; Raboisson et al., 2014; Suthar et al., 2013). Therefore, SCK affects farm productivity and profitability. Estimating the economic impact of SCK may make farmers more aware of this problem, and can improve their decisionmaking regarding interventions to reduce SCK.

Two recent studies (McArt et al., 2015; Raboisson et al., 2015) aimed to estimate the economic impact of SCK. Using a deterministic model, McArt et al. (2015) estimated the economic impact at $\$ 289$ per case of SCK. They included only the relation of SCK with metritis, displaced abomasum, and ovarian dysfunction and therefore might have underestimated the total costs of SCK. Raboisson et al. (2015) developed a stochastic simulation model and included more diseases related to SCK, resulting in an estimated economic impact of $€ 257$ per case of SCK. This study, however, did not distinguish between removal risks of cows with only SCK and of cows with SCK and a related disease, which might have led to an over- or underestimation of costs. Furthermore, McArt et al. (2015) and Raboisson et al. (2015) only distinguished primiparous and multiparous cows, while prevalence of SCK and related diseases, milk production, calving interval, energy requirement, and removal risk can differ between multiparous cows (Bar et al., 2008; Berge and Vertenten, 2014; CRV, 2014). Providing information on costs per parity can support farmers to take cow specific decisions. Moreover, it provides insight into the costs per cow to invest for preventing SCK.

Our objective was to estimate the economic impact of SCK using a dynamic stochastic simulation model. This model includes related diseases of SCK, distinguishes between the removal risks of 
cows with only SCK and of cows with SCK and a related disease, and estimates the economic impact for different parities.

\section{Material and methods}

A dynamic stochastic simulation model was developed to estimate the economic impact of SCK for a typical Dutch dairy farm, applying $8 \mathrm{~h} / \mathrm{d}$ grazing for $170 \mathrm{~d} / \mathrm{yr}$ (CBS, 2014). The model simulates the dynamics and losses of SCK and related diseases during the first 30 days after calving for one lactation, and estimates the economic impact related to these diseases. The model contains four parts (Figure 1). In part one, cow characteristics, e.g. parity and milk production, are simulated and energy requirements for a healthy cow are estimated. In part two, the dynamics of SCK and related diseases are simulated. In part three, losses due to the diseases in the second part are estimated. In part four, costs of SCK and related diseases are calculated.

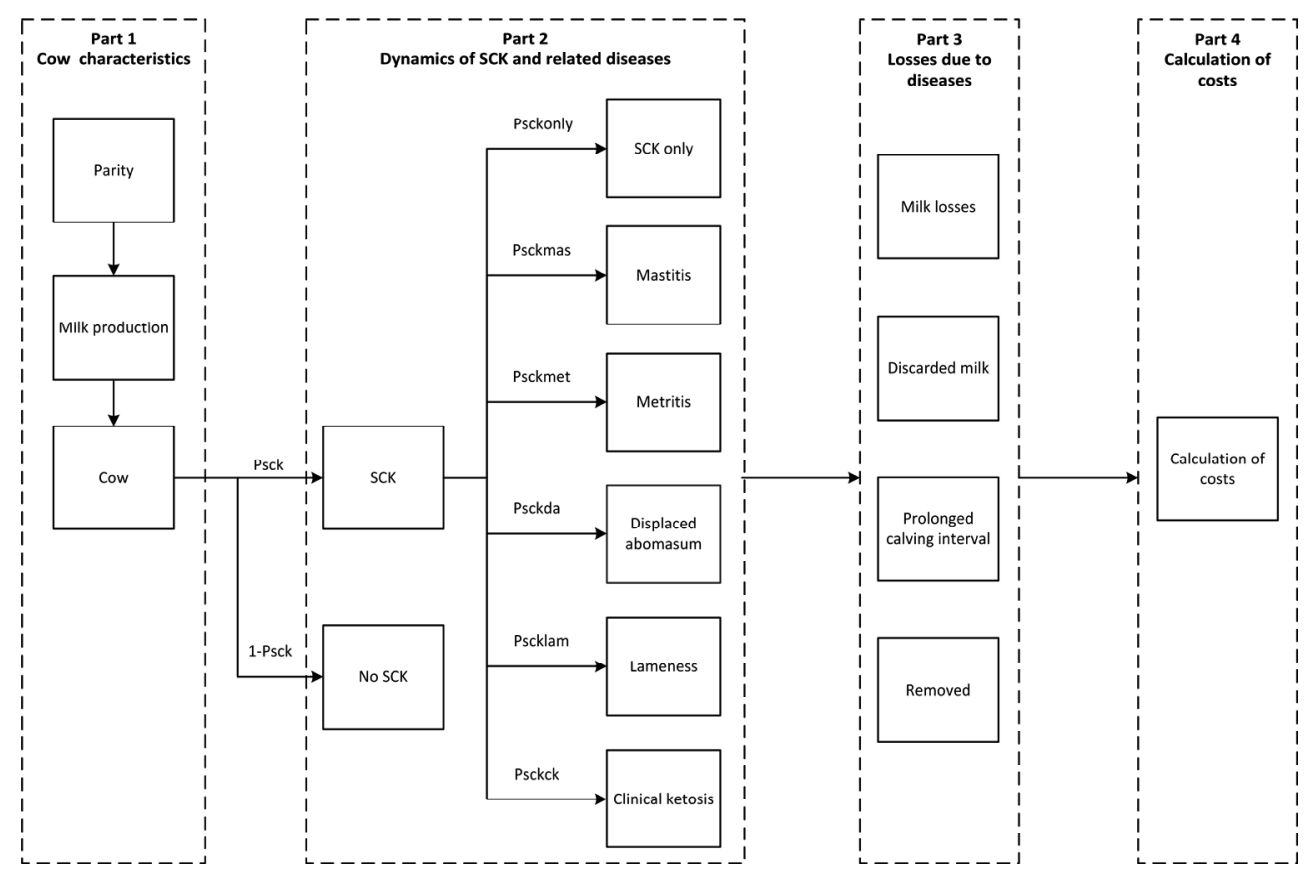

Figure 1. Overview of the four parts in the model to estimate the costs of subclinical ketosis (SCK) in dairy cows. $\mathrm{P}$ = probability. 
92 | Chapter 5

All four parts are described below and parts one to three are described in some more detail in Supplementary Material S1. All input values in the model were based on literature. The model was developed in R (R_Core_Team, 2016) and was run with 1000 ooo iterations.

\section{Cow characteristics (part 1)}

Each cow receives a parity (1-5+), which is based on a weighted herd average (CRV, 2014). Based on the parity, the cow receives a body weight, a milk production level, and a calving interval (CRV, 2014; CVB, 2012) (Table 1). Milk production level per parity is determined with a normal distribution function. The calving interval (CI) consists of a lactation period (350-361 d) and a dryperiod (6o d). A lactation curve is utilized to estimate the average daily milk production per cow based on weekly milk records (Wood, 1967). Net energy requirement for maintenance, milk production, pregnancy, and growth in case of parity 1 and 2 is estimated per day (CVB, 2012).

Energy requirement for maintenance was assumed to be $6.7 \%$ higher in summer ( $170 \mathrm{~d} / \mathrm{yr}$ ) than in winter (195 d/yr), because of grazing (CVB, 2012). The CI of all parities is longer than a year and therefore the summer and winter period of the CI was estimated using the yearly fraction of grazing (170/365). Finally, energy requirements and milk production of a cow are expressed in 365 days using the yearly fraction of the CI $(365 / \mathrm{CI})$.

\section{Dynamics of subclinical ketosis and related diseases (part 2)}

The model includes SCK and related diseases mastitis, metritis, displaced abomasum (DA), lameness, and clinical ketosis occurring in the first 30 days after calving (Table 2). First, based on parity, each cow has a probability to get SCK. Second, each cow with SCK has, based on parity, an additional probability to get mastitis, metritis, DA, lameness or clinical ketosis (Table 1). Although in practice cows might get more than one related disease after SCK in the first 30 days, no data were available about probabilities of multiple diseases after SCK, nor on the interactions of these multiple diseases on production. Therefore, in the developed simulation model each cow could get only one of these related diseases after SCK. The day of occurrence of SCK was set at day 5 after calving (McArt et al., 2012). Related diseases only occurred after SCK. Thus, a cow could have no disease, SCK only, or SCK and a related disease. Cows without SCK were excluded from further analysis. Probabilities of SCK, and related diseases per parity in the first 30 days after calving were computed using data of Berge and Vertenten (2014). 
Table 1. Cow characteristics and probabilities of diseases per parity to estimate the economic impact of subclinical ketosis (SCK) in dairy cows.

\begin{tabular}{|c|c|c|c|c|c|c|}
\hline Input value & Parity 1 & Parity 2 & Parity 3 & 3 Parity 4 & Parity $5+$ & Source \\
\hline Cows (\%) & 33 & 27 & 17 & 11 & 12 & CRV (2014) \\
\hline Milk production (kg) (mean/305d) & 7535 & 8788 & 9383 & 9493 & 9209 & CRV (2014) \\
\hline Calving interval (d) & 410 & 413 & 415 & 419 & 421 & CRV (2014) \\
\hline Weight cow (kg) & 540 & 595 & 650 & 650 & 650 & CVB (2012) \\
\hline \multicolumn{7}{|l|}{ Subclinical ketosis } \\
\hline Probability ${ }^{1}$ SCK (\%) & 19.8 & 23.5 & 28.5 & 32.0 & 31.3 & Berge and Vertenten (2014) \\
\hline Milk losses (d 1-30) (\%) & 7.0 & 7.0 & 7.0 & 7.0 & 7.0 & Adapted from McArt et al. (2012) \\
\hline \multicolumn{7}{|l|}{ Mastitis } \\
\hline Ad. probability ${ }^{3}(\%)$ & 6.6 & 9.1 & 8.6 & 1.6 & 20.2 & Berge and Vertenten (2014) \\
\hline Milk loss (d31-el²) (\%) & 5.0 & 5.0 & 5.0 & 5.0 & 5.0 & Seegers et al. (2003) \\
\hline Culling probability ${ }^{4}(\%)$ & 0.0 & 1.9 & 4.6 & 8.3 & 8.3 & Bar et al. (2008) \\
\hline Death probability ${ }^{4}(\%)$ & 1.5 & 1.2 & 2.8 & 3.9 & 3.9 & Bar et al. (2008) \\
\hline \multicolumn{7}{|l|}{ Metritis } \\
\hline Ad. probability (\%) & 7.3 & 4.4 & 2.2 & 2.0 & 6.4 & Berge and Vertenten (2014) \\
\hline Milk loss (d 31-60) (\%) & 3.8 & 3.8 & 3.8 & 3.8 & 3.8 & Gröhn et al. (2003); Rajala and Gröhn (1998) \\
\hline \multicolumn{7}{|l|}{ Displaced abomasum } \\
\hline Ad. probability (\%) & 3.7 & 6.9 & 15.1 & 3.7 & 0.0 & Berge and Vertenten (2014) \\
\hline Milk loss (in $305 \mathrm{~d})^{5}(\%)$ & 3.3 & 4.7 & 4.7 & 4.7 & 4.7 & Raizman et al. (2002) \\
\hline Culling probability (\%) & 1.7 & 1.3 & 3.2 & 5.8 & 5.8 & Bar et al. (2008) \\
\hline Death probability (\%) & 1.0 & 1.0 & 2.4 & 3.3 & 3.3 & Bar et al. (2008) \\
\hline \multicolumn{7}{|l|}{ Lameness } \\
\hline Ad. probability (\%) & 1.3 & 0.3 & 6.9 & 10.3 & 0.0 & Berge and Vertenten (2014) \\
\hline Milk loss (d31- el) (\%) & 5.7 & 5.7 & 5.7 & 5.7 & 5.7 & Raboisson et al. (2014) \\
\hline Culling probability (\%) & 4.0 & 4.0 & 4.0 & 4.0 & 4.0 & Bruijnis et al. (2010) \\
\hline \multicolumn{7}{|l|}{ Clinical ketosis } \\
\hline Ad. probability (\%) & 10.5 & 11.4 & 21.4 & 21.0 & 21.9 & Berge and Vertenten (2014) \\
\hline Death probability (\%) & 0.0 & 0.7 & 1.7 & 2.5 & 2.5 & Bar et al. (2008) \\
\hline
\end{tabular}

${ }^{1}$ Probabilities were obtained and calculated from data of the study Berge and Vertenten (2014)

${ }^{2}$ End of lactation period

3 Ad. probability: Additional probability of cow getting a disease with SCK were obtained and calculated from data of the study Berge and Vertenten (2014), probabilities were estimated as the difference between the probability of the cow getting the disease with SCK and the probability of the cow getting the disease without SCK

4 Additional probability on getting culled or died were calculated for the disease

5 Reduced milk production losses for displaced abomasum were estimated over 305 days but only occurred in months 1-4. Daily milk loss (kg/day) was estimated and reduced milk production losses occurred after day 30. 
Table 2. Disease incidence and consequences on production parameters used to estimate the economic impact of subclinical ketosis (SCK) and related diseases in dairy cows.

\begin{tabular}{|c|c|c|c|c|c|}
\hline Disease & $\begin{array}{l}\text { Total incidence }{ }^{1} \\
\text { (\%) }\end{array}$ & $\begin{array}{l}\text { Occurrence } \\
\text { in lactation (d) }\end{array}$ & $\begin{array}{l}\text { Discarded } \\
\text { Milk (days) }\end{array}$ & $\begin{array}{l}\text { Prolonged calving } \\
\text { interval (days) }\end{array}$ & Source \\
\hline Subclinical ketosis & 25.0 & 5 & 0 & 19 & $\begin{array}{l}\text { McArt et al. (2012); Raboisson et al. } \\
\text { (2015); Walsh et al. (2007) }\end{array}$ \\
\hline Clinical ketosis & 4.0 & 13 & 3.5 & 6 & $\begin{array}{l}\text { Duffield et al. (2009); Fourichon et } \\
\text { al. (2000) }\end{array}$ \\
\hline Mastitis & 12.5 & 8 & 6 & 28 & $\begin{array}{l}\text { Santos et al. (2004); Wilson et al. } \\
\text { (2004) }\end{array}$ \\
\hline Metritis & 10.2 & 10 & 7 & 18 & $\begin{array}{l}\text { Fourichon et al. (2000); Overton } \\
\text { and Fetrow (2008) }\end{array}$ \\
\hline Displaced abomasum & 4.0 & 10 & 7 & 15 & $\begin{array}{l}\text { Duffield et al. (2009); Jorritsma et } \\
\text { al. (2008); McArt et al. (2012); } \\
\text { Raizman et al. (2002) }\end{array}$ \\
\hline Lameness & 4.5 & 8 & 0 & 12 & $\begin{array}{l}\text { Bruijnis et al. (2010); Fourichon et } \\
\text { al. (2000) }\end{array}$ \\
\hline
\end{tabular}

${ }^{1}$ Total disease incidence in the first 30 days after calving in the herd

Disease incidence at herd level varies across literature. To represent an average incidence rate while accounting for the difference in RR (risk ratio) across parities and across different combinations of diseases, disease probabilities per parity found by Berge and Vertenten (2014) were up- or downscaled to match average disease incidence at herd level found in literature (Table 2).The additional probability to get a related disease because of SCK was estimated as the difference between the probability to get this disease with SCK and the probability to get it without SCK. It was assumed that only cows with SCK could get clinical ketosis. Third, each cow with SCK and a related disease has a probability to get culled or to die on the farm, together called removal. These probabilities depend on the parity of the cow and the related disease, and were based on removal rates in the first two months of the lactation (Table 1). In practice, cows that suffered SCK and a related disease may be removed at a later stage of the lactation, e.g. because of related fertility problems. No data, however, were available to relate removals at a later stage to SCK. Therefore, in the simulation model the day of removal was set at day 30 after calving.

The discrete events on getting SCK, a related disease after SCK, and removal from the herd are simulated by using random numbers drawn from uniform distributions.

\section{Losses due to diseases (part 3)}

Cows with SCK have a reduced milk production (\%/d), which is disease specific (Table 1). During the first 30 days of the lactation, each cow with SCK has the same reduced milk production, irrespectively of whether the cow has SCK only or SCK and a related disease, because no data were available to differentiate in milk losses in the first 30 days. Cows with SCK and a related disease 
also have a reduced milk production after day 30 for a period which is disease specific. These cows receive a disease specific treatment. This treatment is based on the average treatment protocols provided by seven veterinarians, who were randomly selected from different clinics in the Netherlands, and on information from literature. If the cow is treated with antibiotics, the milk is discarded for the prescribed days (Table 2). When a cow is removed, she is immediately replaced by a heifer with average production parameters. A new heifer, however, has a lower milk production than a cow from parity 2-5+ and, therefore, removal results in milk losses. Cows with SCK that are not removed from the herd have a reduced fertility. Reduced fertility is included in the model by a prolonged CI of the cow (Table 2). It was assumed that the number of inseminations did not change. The dry period of a cow with SCK did not change and was set to 60 days, but the duration of the lactation period was increased. The prolonged CI depends on the (combination of) disease(s). Since no data were available on the combined effect of SCK and related diseases on CI, the impact on CI was determined by adding all the extra days of the disease with the largest effect on CI, and half of the extra days of the other disease, which was adapted from the method of Gröhn et al. (2003).

After summing all the milk losses, milk production and net energy requirement per lactation are determined and converted to an average per year based on the CI of the cow. Milk losses per cow per year are estimated as the difference between the milk production of the cow with and without SCK.

\section{Calculation of costs (part 4)}

The total costs of SCK (TCsck $_{\mathrm{i}}$ (Eq. (1)) for cow (i) with SCK are estimated as:

$\mathrm{TCsck}_{\mathrm{i}}=\mathrm{Cmilk}_{\mathrm{i}}+\mathrm{Ctreat}_{\mathrm{i}}+\mathrm{Cmilkmd}_{\mathrm{i}}+\mathrm{Crem}_{\mathrm{i}}+\mathrm{Cci}_{\mathrm{i}}$

where, Cmilk are costs from reduced milk production (Eq. (2)), Ctreat treatment costs, Cmilkmd costs related to discarded milk (Eq. (3)), Crem costs from removal, and Cci costs related to a prolonged calving interval (Eq. (5)).

Costs for reduced milk production are estimated as:

$\mathrm{Cmilk}_{\mathrm{i}}=\mathrm{ML}_{\mathrm{i}} \times \mathrm{MP}-\mathrm{FIDL}_{\mathrm{i}} \times \mathrm{FP}$

where, $M L_{i}$ is reduced milk production in kilogram of cow (i) with SCK, MP is milk price per

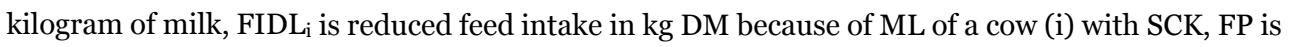
feed price per $\mathrm{kg} \mathrm{DM}$ of the diet. 
Milk price was based on average price of milk from the last 9 years (KWIN-V, 2014).

A diet was composed to estimate the costs related to feeding. A diet for the summer and winter period consisted of concentrates and roughage. Roughage consisted of grass, grass silage and maize silage (CBS, 2014). Energy content per kilogram of dry matter feed was estimated for the summer (6.78 MJ/kg DM) and the winter period (6.53 MJ/kg DM) based on a weighted energy content of the feed ingredients (Table 3 ). Costs of feed were $0.163 € / \mathrm{kg}$ DM in the summer period

Table 3. Dietary composition and feed characteristics used to assess the economic impact of subclinical ketosis and related diseases in dairy cows.

\begin{tabular}{|c|c|c|c|c|}
\hline Feed ingredient & $\begin{array}{l}\text { Net energy of feed }{ }^{2} \\
\text { (MJ/kg DM) }\end{array}$ & $\begin{array}{l}\text { Feed price }^{3} \\
(€ / \text { kg DM) }\end{array}$ & $\begin{array}{l}\text { Summer diet }^{4} \\
(\% / \mathrm{kg} \mathrm{DM})\end{array}$ & $\begin{array}{l}\text { Winter diet }{ }^{4} \\
(\% / k g ~ D M)\end{array}$ \\
\hline Concentrates with standard protein ${ }^{1}$ & 7.43 & 0.24 & 0.21 & 0.20 \\
\hline Concentrates with extra protein ${ }^{1}$ & 7.45 & 0.28 & 0.00 & 0.07 \\
\hline Wet by-products & 7.50 & 0.12 & 0.04 & 0.05 \\
\hline Grass & 6.95 & 0.11 & 0.39 & 0.00 \\
\hline Grass silage & 6.08 & 0.18 & 0.25 & 0.55 \\
\hline Maize silage & 6.26 & 0.17 & 0.11 & 0.14 \\
\hline \multicolumn{5}{|c|}{ Average taken from four years (Nevedi, 2015) } \\
\hline \multicolumn{5}{|l|}{${ }^{2}$ Vellinga et al. (2013) } \\
\hline \multicolumn{5}{|l|}{3 KWIN-V (2014) } \\
\hline BS (2014) & & & & \\
\hline
\end{tabular}

and $0.195 € / \mathrm{kg}$ DM in the winter period (Table 4). Based on the estimated net energy requirement of the cow and the net energy content of the feed, DM intake per cow per year was estimated for the same cow with and without SCK. It was assumed that the feed intake of the cow was equal to the energy requirement of the cow. Reduced feed intake per cow per year was estimated as the difference between DM intake of the same cow with and without SCK. The energy requirements for maintenance were the same for cows with or without a disease, while the energy requirement for milk changed with a change in milk yield. As a result, cows with SCK were found to have a lower feed efficiency and a higher energy requirement per $\mathrm{kg}$ of milk produced.

Treatment costs (Ctreat ${ }_{\mathrm{i}}$ ) are estimated for cows that had a related disease after SCK. The costs for treatment were based on costs of medication, extra labor for the farmer and the consultation of the veterinarian (Table 4). Cows that are treated receive antibiotics and milk is discarded during this period. All discarded milk is considered waste. 
Costs for discarded milk are estimated as:

$\mathrm{Cmilkmd}_{\mathrm{i}}=\mathrm{Mmd}_{\mathrm{i}} \times \mathrm{MP}$

where, $\mathrm{Mmd}_{\mathrm{i}}$ is $\mathrm{kg}$ discarded milk of cow (i).

Table 4. Monetary values used to assess the economic impact of subclinical ketosis (SCK) and related diseases in dairy cows.

\begin{tabular}{lll}
\hline Input value & Value & Source \\
\hline Milk price ( $€ /$ kg milk) & 0.34 & KWIN-V (2014) \\
Feed price summer diet $(€ /$ kg DM) & 0.162 & KWIN-V (2014) \\
Feed price winter diet $(€ /$ kg DM) & & KWIN-V (2014) \\
Labour costs farmer ( $€ /$ hour) & 0.195 & KWIN-V (2014) \\
Opportunity costs heifer ( $€ /$ heifer) & 19 & LEI (2014) \\
Meat price ( $€ /$ kg slaughter weight) & 950 & LEI (2014) \\
Disposal cow $(€ /$ cow) & 2.2 & Rendac (2015) \\
Price calf ( $€ /$ calf) & 39 & LEI (2014) \\
Average costs rate veterinarian per visit $(€)$ & 25 & Elanco Animal Health (personal communication) \\
Total treatment costs disease per case $(€)$ & 90 & Elanco Animal Health (personal communication) \\
Clinical ketosis & 43 & \\
Mastitis & 102 & \\
Metritis & 67 & \\
Displaced abomasum & 146 & \\
Lameness & 13 & Bruijnis et al. (2010) \\
\hline
\end{tabular}

${ }^{1}$ Feed price is based on a weighted average of feed composition

Costs of removal (Crem) consist of costs because of milk losses (Cmilkrem) (Eq. (4)) and extra removal costs, because of early introduction of a new heifer.

Costs for milk losses because of removal are estimated as:

Cmilkrem $_{i}=$ MLrem $_{i} \times$ MP $-\left(\right.$ FIDrem $_{i} \times$ FP $)$

where, MLrem $_{\mathrm{i}}$ is milk losses in kilogram of cow (i) because of removal, FIDrem $\mathrm{i}$ is reduced feed intake in $\mathrm{kg}$ DM because of MLrem of cow (i) that was removed.

Cows that are removed before the end of parity 5 are assumed to be removed too early, resulting in extra costs for raising extra heifers. Extra removal costs are estimated with a depreciation method (Getaneh et al. 2017). First, the difference between the opportunity costs of a new heifer and the slaughter price of a heifer is estimated. Second, this difference is depreciated over the total amount of milk that is produced by the cow at the moment of removal. For cows that are removed at parity 2+, average milk production levels were assumed for all previous parities. 
The opportunity costs of a new heifer is based on the average price of a heifer from the period 20052014 (LEI, 2014). The slaughter price of a heifer consists of the slaughter weight of the heifer multiplied with the meat price per kilogram slaughter weight. Slaughter weight of the heifer is estimated with an assumed dressing percentage of $60 \%$ (Rutten et al., 2014). It is assumed that the meat price per kilogram slaughter weight of a cow with a disease ( $€ 1.82 / \mathrm{kg}$ slaughter weight) is lower than of a cow without a disease. This revenue foregone is added when the cow is culled and when the cow dies, the slaughter price of the cow is added. Costs for disposal of the dead cow are also included (Rendac, 2015).

Costs for a prolonged calving interval $\left(\mathrm{Cci}_{\mathrm{i}}\right)$ consist of milk losses because of a prolonged $\mathrm{CI}$ and the difference in annual number of calves (Eq. (5)). Reduced milk production that occurred in the extended period of the $\mathrm{CI}$ is allocated to Cci.

$\mathrm{Cci}_{i}=\mathrm{MLci}_{\mathrm{i}} \times \mathrm{MP}-\mathrm{FIDci}_{\mathrm{i}} \times \mathrm{FP}+$ Calfd $_{\mathrm{i}} \times$ CalfP

where, MLci i is milk losses in kilogram of cow (i) because of prolonged CI; FIDci is reduced feed intake in $\mathrm{kg}$ DM because of $\mathrm{MLc}_{\mathrm{i}}$ of cow (i); Calfd is reduced number of calves, and CalfP is price per calf.

Total costs of SCK are expressed per case of SCK per year and will be presented in the results as an average with the 5-95\% percentile between brackets. In addition, the median is given in tables. Costs of SCK were analysed per parity, per different costs contributor and per disease (combination).

\section{Sensitivity analysis}

A sensitivity analysis was performed to analyse the impact of changes in input parameters on the economic impact of SCK. Input parameters of the reference situation (Table 1, 2, 3, and 4) were adjusted to alternative values and the impact of alternative values were analysed separately.

Probabilities of each disease, and probabilities of removal of all diseases were adjusted. Probabilities of getting mastitis, or metritis, or DA, or lameness, or clinical ketosis were increased and decreased with 50\% (Increased P per disease), whereas probabilities of removal were doubled (Increased P remova).

The RR and removal probabilities of metritis and DA were increased based on values found in literature. The RR of metritis for cows with SCK was increased from 1.4 to 3.3 (Increased risk ratio metritis) (Duffield et al., 2009). The RR of DA for cows with SCK was increased from 3.7 to 8.0 (Increased risk ratio DA) (LeBlanc et al., 2005). Furthermore, in each parity removal risk of DA 
and metritis were increased to $23.4 \%$ (DA) and to 6.0\% (metritis) (Increased P removal metritis and $D A$ ) ( Overton and Fetrow, 2008; Raizman et al., 2002).

Milk price, and opportunity costs of a heifer were adjusted. Milk price was adjusted from $0.344 € /$ $\mathrm{kg}$ milk to the highest (0.416 €/ kg milk) (Increased milk price) and lowest (0.269 €/ kg milk) (Decreased milk price) milk price from the last 9 years in the Netherlands (KWIN-V, 2014). Opportunity costs of the heifer were increased from $€ 950$ to $€ 1790$ (Increased opportunity costs heifer) (Mohd Nor et al., 2015).

\section{Results}

\section{Simulation results}

Total costs of SCK averaged $€_{130}$ per case per year, with a range between $€_{39}$ and $€_{348}$ (5-95 percentiles). Most cows had SCK only (61\%); for these cows costs averaged $€ 58$ (39-72) per case per year. Costs of cows with SCK and related diseases that were not removed averaged $€ 222$ (110357) per case per year, whereas costs of cows with SCK and related diseases that were removed averaged $€ 812$ (335-1 323) per case per year.

Total costs of SCK per case per year were contributed by: $36 \%$ from a prolonged CI, $24 \%$ from reduced milk production, $19 \%$ from treatment, $14 \%$ from discarded milk, and $6 \%$ from removal (Table 5). Furthermore, total costs of SCK per case per year came from $27 \%$ of cows with SCK only, $25 \%$ of cows with SCK and mastitis, $19 \%$ of cows with clinical ketosis, $17 \%$ of cows with SCK and DA, $7 \%$ of cows with SCK and metritis, and $5 \%$ of cows with SCK and lameness (Table 6 ).

Total costs of SCK varied from $€ 83$ (38-271) per case per year in parity 1 , to $€ 175$ ( $€ 64$ and $€ 362$ ) in parity 3 (Table 5 and 6). Across parities, costs associated with a prolonged CI contributed most to the total costs, whereas costs related to removal contributed least. 
100 | Chapter 5

Table 5. Average costs of subclinical ketosis per parity per case per year (0.05-0.50-0.95 percentiles) related to reduced milk production, milk discard, treatment, prolonged calving interval, and removal in dairy cows.

\begin{tabular}{lllllll}
\hline Contributor (€/yr) & Parity 1 & Parity 2 & Parity 3 & Parity 4 & Parity 5+ & Average $^{1}$ \\
\hline Reduced milk production & 22 & 30 & 44 & 33 & 35 & 32 \\
& $(13-14-95)$ & $(15-17-109)$ & $(16-18-125)$ & $(16-18-130)$ & $(16-18-116)$ & $(13-17-115)$ \\
Milk discard & 12 & 17 & 27 & 13 & 25 & 18 \\
& $(0-0-56)$ & $(0-0-69)$ & $(0-0-76)$ & $(0-0-70)$ & $(0-0-70)$ & $(0-0-71)$ \\
Treatment & 19 & 24 & 37 & 16 & 30 & 25 \\
& $(0-0-91)$ & $(0-0-129)$ & $(0-11-129)$ & $(0-0-89)$ & $(0-0-88)$ & $(0-0-129)$ \\
Prolonged calving interval & 28 & 50 & 53 & 53 & 55 & 46 \\
& $(24-27-39)$ & $(43-47-77)$ & $(45-51-82)$ & $(46-52-66)$ & $(44-52-85)$ & $(25-48-77)$ \\
Removal & 1 & 4 & 15 & 10 & 18 & 8 \\
& $(0-0-0)$ & $(0-0-0)$ & $(0-0-0)$ & $(0-0-0)$ & $(0-0-0)$ & $(0-0-0)$ \\
Total & 83 & 125 & 175 & 126 & 164 & 130 \\
& $(38-41-271)$ & $(59-65-340)$ & $(64-138-362)$ & $(63-72-336)$ & $(62-74-361)$ & $(39-69-348)$ \\
\hline
\end{tabular}

${ }^{1} \mathrm{~A}$ weighted average for all parities was taken which was based on an average Dutch dairy herd composition

Table 6. Average costs of subclinical ketosis (SCK) per parity per case per year (0.05-0.50-0.95 percentiles) related to dairy cows with SCK only, and dairy cows with SCK and a related disease.

\begin{tabular}{lllllll}
\hline Contributor (€/yr) & Parity 1 & Parity 2 & Parity 3 & Parity 4 & Parity 5+ & Average $^{1}$ \\
\hline SCK only & 29 & 43 & 31 & 42 & 34 & 36 \\
& $(0-39-43)$ & $(0-61-68)$ & $(0-0-73)$ & $(0-65-74)$ & $(0-59-71)$ & $(0-41-71)$ \\
SCK + mastitis & 19 & 31 & 34 & 7 & 78 & 32 \\
& $(0-0-268)$ & $(0-0-334)$ & $(0-0-351)$ & $(0-0-0)$ & $(0-0-359)$ & $(0-0-337)$ \\
SCK + metritis & 12 & 10 & 5 & 4 & 14 & 9 \\
& $(0-0-165)$ & $(0-0-0)$ & $(0-0-0)$ & $(0-0-0)$ & $(0-0-215)$ & $(0-0-0)$ \\
SCK + DA & 10 & 24 & 57 & 14 & 0 & 22 \\
& $(0-0-0)$ & $(0-0-323)$ & $(0-0-350)$ & $(0-0-0)$ & $(0-0-0)$ & $(0-0-316)$ \\
SCK + lameness & 2 & 1 & 15 & 22 & 0 & 7 \\
& $(0-0-0)$ & $(0-0-0)$ & $(0-0-197)$ & $(0-0-205)$ & $(0-0-0)$ & $(0-0-0)$ \\
Clinical ketosis & 11 & 17 & 34 & 36 & 38 & 25 \\
& $(0-0-108)$ & $(0-0-142)$ & $(0-0-148)$ & $(0-0-154)$ & $(0-0-150)$ & $(0-0-147)$ \\
Total & 83 & 125 & 175 & 126 & 164 & 130 \\
& $(38-40-271)$ & $(59-65-340)$ & $(64-138-362)$ & $(63-72-336)$ & $(62-74-361)$ & $(39-69-348)$
\end{tabular}

${ }^{1} \mathrm{~A}$ weighted average for all parities was taken which was based on the composition of an average Dutch dairy herd

${ }^{2}$ Displaced abomasum

\section{Sensitivity analysis}

Results of the sensitivity analysis are shown in Figure 2. Increasing the probabilities of mastitis increased the costs of SCK per case per year by $10 \%$, whereas increasing the probabilities of DA increased costs by $7 \%$. A decrease in probabilities of diseases resulted in a similar but opposite effect (results not shown). Doubling the removal probabilities of diseases increased costs of SCK by $5 \%$ per case per year. 
Increasing the RR of metritis for cows with SCK increased the costs by $12 \%$ per case per year, whereas increasing the RR of DA for cows with SCK increased the costs by $9 \%$. Increasing the removal risk of DA and metritis increased the costs of SCK by $5 \%$ per case per year.

A higher milk price increased the costs of SCK by $20 \%$ per case per year, whereas a lower milk price decreased the costs of SCK by $21 \%$ per case per year. An increase in the opportunity costs of a heifer increased the costs of SCK by $3 \%$ per case per year.

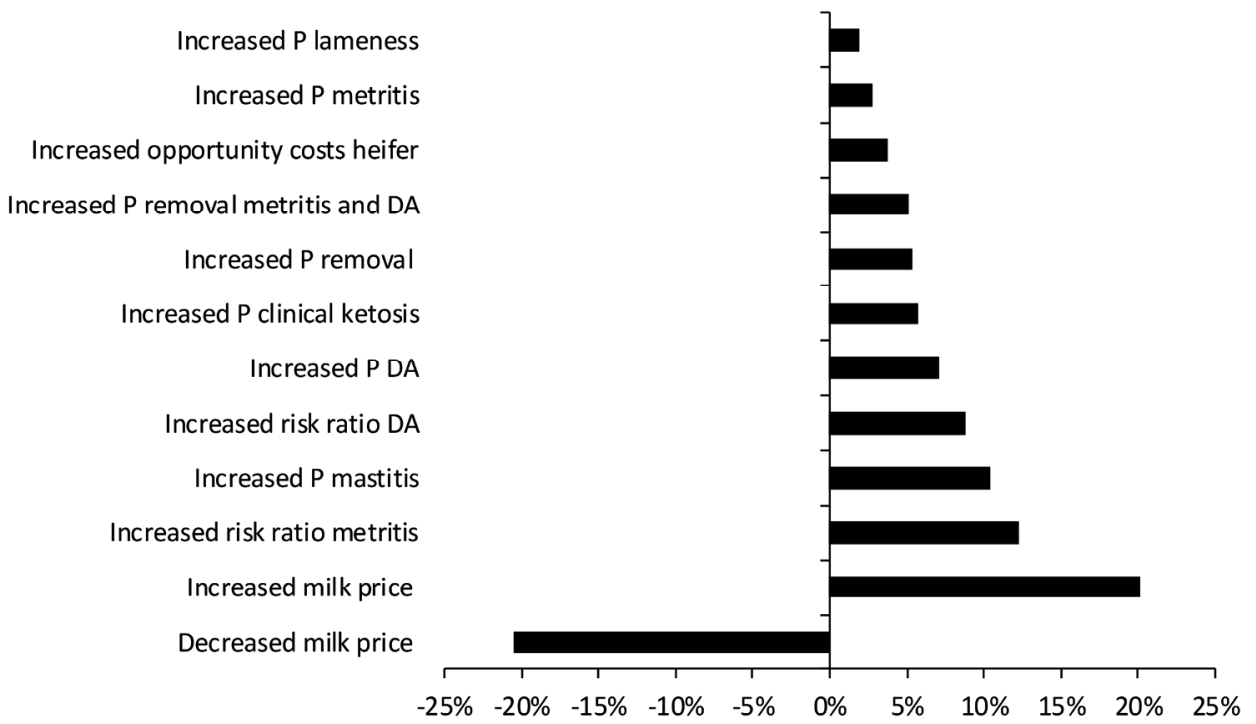

Figure 2. Results from the sensitivity analyses, showing the effect (\%) of a change in input parameters on costs of subclinical ketosis per case per year in dairy cows. $\mathrm{P}=$ probability, $\mathrm{DA}=$ displaced abomasum.

\section{Discussion}

Our objective was to estimate the economic impact of SCK. In our study, total costs of SCK were $€ 130$ per case per year, whereas Raboisson et al. (2015) reported average costs of $€ 257$ per cow per calving and McArt et al. (2015) \$289 per case. In contrast to these two studies, we used dynamic stochastic modelling of five parities, and adjusted the quantification for the costs of removal. In addition, different input parameters also had an impact on the costs. Below, we will discuss these three differences. 


\section{Dynamic stochastic modelling of five parities}

By using data from Berge and Vertenten (2014) we were able to estimate the costs for cows in parity 1 to parity $5+$. Most studies that estimate the economic impact of diseases differentiate between primiparous and multiparous cows (McArt et al., 2015; Raboisson et al., 2015) or assume equal probabilities among parities (Halasa et al., 2009). Our study, however, showed that costs per cow differ among parities. Grouping parities, therefore, is less accurate and might result in over- or underestimation of the costs. Parity specific disease probabilities of Berge and Vertenten (2014), however, were derived from data collection in different countries. This could have influenced the results. Because of lack of literature, we were unable to compare the results of cows per parity with other studies.

The stochastic models (Raboisson et al. (2015) and our study) were able to show the range of costs and are therefore potentially more informative for decision makers.

Our model, moreover, showed that most cows with a disease in the first 30 days after calving had SCK only. Costs of cows with SCK only were lower than the average costs of SCK, which resulted in a skewed distribution of the total costs. Costs of cows with SCK and a related disease, and costs of cows with SCK and a related disease that were removed were higher, and therefore affected the total costs of SCK considerably. Because farmers do not directly see the link between SCK and other diseases, this might easily lead to underestimation of the costs of SCK. Therefore, we estimated the mean, and also the 5, 50, and 95 percentiles of the costs of SCK to give a complete overview.

Our model was dynamic, while Raboisson et al. (2015) used a static model. The dynamic approach allowed simulation of milk, reproduction, and removal losses over time. Therefore, we argue that a dynamic stochastic simulation model has the potential to be most accurate.

\section{Costs of removal}

Removal is the most important aspect that influenced the difference in economic impact of SCK between our study and previous studies. In our study, costs of removal contributed about $6 \%$ to the total costs of SCK, whereas in other studies, removal contributed 30\% (Raboisson et al., 2015) or 34\% (McArt et al., 2015) . Raboisson et al. (2014) did a meta-analysis on the relation between SCK and culling based on three studies in the USA and Canada and highlighted the scarcity of literature on SCK and culling. Differences in the costs of removal between our study and these two studies are two-fold. First, the number of cows removed because of SCK was lower in our study. McArt et al. (2015) and Raboisson et al. (2015) used a RR of 1.8 and 1.92 to estimate the number cows that were removed because of SCK. This means that every cow with SCK, with and without a related disease, had an increased risk of being removed. In our study, however, we assumed that a cow with 
SCK only was not removed, because the peak of milk production of the cow is in prospect and therefore the highest profit. Cows were removed at day 30 after calving. Removal of cows in a later stage of the lactation (e.g. because of reproduction problems due to diseases), could not be included, which might have resulted in an underestimation of removal risk. Relating removal of a cow at a later stage of lactation to a disease that occurred in the first 30 days after lactation, however, is difficult, because removal is influenced by all kind of factors. No data were available to relate removals at a later stage to SCK. Results of the sensitivity analysis, however, showed the importance of improving estimations on removal risks. Including removal at a later stage of the lactation will increase the costs of SCK.

Second, the costs of a removed cow in our study were lower than in the previous studies (McArt et al., 2015; Raboisson et al., 2015). McArt et al. (2015) and Raboisson et al. (2015) estimated the costs as the difference between the economic value of a calving heifer and the economic value of a slaughtered cow. In addition, Raboisson et al. (2015) added an extra 25\% early culling cost. Our removal costs consisted of extra removal costs and milk losses and were on average lower per case of removal (results not shown). Extra removal costs per parity were estimated based on depreciation to differentiate between the five parities. In addition, the opportunity costs of a heifer had an important impact on the results. These costs were higher in France ( $€ 1400)$ (Raboisson et al., 2015) and in the USA (\$1 900) (McArt et al., 2015) than in our study (€950), resulting in higher costs.

\section{Input of the model}

Incidence of diseases, RR of related diseases when a cow has SCK, and prices for the Dutch situation had an important impact on the total costs of SCK. Related diseases in our study were selected based on Berge and Vertenten (2014), who provided probabilities for the diseases mastitis, metritis, DA, lameness, and clinical ketosis, gastrointestinal disorder, milk fever and retained placenta. The latter three were not included in our study because the relation between those diseases and SCK are not analysed in many other studies, and because retained placenta and milk fever, can also be a precursor of SCK instead of a consequence (Berge and Vertenten, 2014). The relations between SCK and DA, SCK and metritis, and SCK and clinical ketosis are well documented (Raboisson et al., 2014). A few studies have analysed the relations of SCK and somatic cell count, retained placenta, and subclinical endometritis as included by Raboisson et al. (2015), but those studies did not show a clear relation (Raboisson et al., 2014). In addition, Raboisson et al. (2015) showed that those related diseases only contributed $4 \%$ to the total costs of SCK. Excluding those diseases from our study, therefore, will not have affected the results. The relation between SCK and mastitis, and SCK 
and lameness have been analysed only in a few studies with different results (Suthar et al., 2013; Berge and Vertenten, 2014). The contribution of cows with SCK and mastitis, and SCK and lameness was $29 \%$ to the average total costs, and therefore have a relative high but uncertain impact on total costs.

The incidence of diseases and RR of SCK with related diseases used in our study were similar to those used by Raboisson et al. (2015). Incidences of diseases, however, vary between countries, regions and farming systems (Berge and Vertenten, 2014; Suthar et al., 2013). Results of the sensitivity analysis showed that an increase or decrease in disease incidence had an important impact on the results, indicating that the costs per case of SCK are likely to vary among farms. The incidence of DA (5\%) and metritis (18.5\%) and RR of metritis (3.3) and with DA (8.0) for cows with SCK were higher in the study of McArt et al. (2015) resulting in higher costs than in our study. Raboisson et al. (2015) already discussed that the risk ratios of DA and metritis for cows with SCK used by McArt et al. (2015) may have been chosen too high. Reduced milk production because of SCK and related diseases varies between studies (Raboisson et al., 2014). Increasing the milk loss in the first 30 days of cows with SCK by $50 \%$ had a minor impact on the results (results not shown), and therefore was excluded.

Insight into the dynamics and economic impact of diseases, such as SCK, can support farmers and their advisors in making decisions on interventions to improve farm profitability and the health status at their farm. Average costs per case of SCK from our and previous studies can be communicated to make more farmers aware of these costs. Farm analysis, however, is necessary to estimate the costs of SCK for a specific farm. Current developments in technology and automation in larger farms can facilitate collection of farm specific data including disease incidences and milk production. For a better estimation of the economic impact of SCK, more information is needed about disease incidence, interaction of SCK with other diseases, cause of removal, reproduction, and milk losses. 


\section{References}

Bar, D., Gröhn, Y.T., Bennett, G., González, R.N., Hertl, J.A., Schulte, H.F., Tauer, L.W., Welcome, F.L., Schukken, Y.H., 2008. Effects of repeated episodes of generic clinical mastitis on mortality and culling in dairy cows. J. Dairy Sci. 91, 2196-2204.

Berge, A.C., Vertenten, G., 2014. A field study to determine the prevalence, dairy herd management systems, and fresh cow clinical conditions associated with ketosis in western European dairy herds. J. Dairy Sci. 97, 2145-2154.

Bruijnis, M.R.N., Hogeveen, H., Stassen, E.N., 2010. Assessing economic consequences of foot disorders in dairy cattle using a dynamic stochastic simulation model. J. Dairy Sci. 93, 2419-2432.

CBS 2014. Dierlijke mest en mineralen 2013. Centraal Bureau voor de Statistiek, Den Haag, the Netherlands.

CRV 2014. Jaarstatistieken 2014 voor Nederland (Annual statistics 2014). CRV, Arnhem, the Netherlands.

CVB 2012. Tabellenboek veevoeding 2012, voedernormen landbouwhuisdieren en voederwaarde veevoeders (Composition and nutritional values of feedstuffs and requirement values), CVB-reeks nr.50, August 2012. Productschap Diervoeder, Den Haag, the Netherlands.

Duffield, T.F., Lissemore, K.D., McBride, B.W., Leslie, K.E., 2009. Impact of hyperketonemia in early lactation dairy cows on health and production. J. Dairy Sci. 92, 571-580.

Fourichon, C., Seegers, H., Malher, X., 2000. Effect of disease on reproduction in the dairy cow: a meta-analysis. Theriogenology 53, 1729-1759.

Getaneh, A.M., Mekonnen, S.A., Hogeveen, H., 2017. Stochastic bio-economic modeling of mastitis in Ethiopian dairy farms. Prev. Vet. Med. 138, 94-103.

Gröhn, Y.T., Rajala-Schultz, P.J., Allore, H.G., DeLorenzo, M.A., Hertl, J.A., Galligan, D.T., 2003. Optimizing replacement of dairy cows: Modeling the effects of diseases. Prev. Vet. Med. 61, 27-43.

KWIN-V, 2014. Quantitative Livestock Farming Information 2014-2015 (Kwantitatieve Informatie Veehouderij 2014-2015). Livestock Research, Wageningen UR, the Netherlands.

Halasa, T., Nielen, M., Huirne, R.B.M., Hogeveen, H., 2009. Stochastic bio-economic model of bovine intramammary infection. Livest. Sci. 124, 295-305.

Jorritsma, R., Westerlaan, B., Bierma, M.P.R., Frankena, K., 2008. Milk yield and survival of Holstein-Friesian dairy cattle after laparoscopic correction of left-displaced abomasum. Vet. Rec. 162, 743-746.

KWIN-V 2014. Kwantitatieve informatie veehouderij 2014-2015 (Quantitative information livestock farming 2014-2015). Wageningen UR Livestock Research, Wageningen, the Netherlands.

LeBlanc, S., 2010. Monitoring metabolic health of dairy cattle in the transition period. J. Reprod. Dev. 56, S29-S35. 
LeBlanc, S.J., Leslie, K.E., Duffield, T.F., 2005. Metabolic predictors of displaced abomasum in dairy cattle. J. Dairy Sci. 88, 159-170.

LEI 2014. Landbouw Economisch Instituut (Agricultural Economic Institute). LEI's Farm Accountancy Data Network, Den Haag, the Netherlands.

McArt, J.A.A., Nydam, D.V., Oetzel, G.R., 2012. Epidemiology of subclinical ketosis in early lactation dairy cattle. J. Dairy Sci. 95, 5056-5066.

McArt, J.A.A., Nydam, D.V., Overton, M.W., 2015. Hyperketonemia in early lactation dairy cattle: A deterministic estimate of component and total cost per case. J. Dairy Sci. 98, 2043-2054.

Mohd Nor, N., Steeneveld, W., Derkman, T.H.J., Verbruggen, M.D., Evers, A.G., de Haan, M.H.A., Hogeveen, H., 2015. The total cost of rearing a heifer on Dutch dairy farms: calculated versus perceived cost. Ir. Vet. J. 68, 1-7.

Nevedi, 2015. De Nederlandse Vereniging Diervoederindustrie, lineaire programmeringen rundvee-, varkens en pluimveevoerders (The Dutch Feed Industry Association, linear programming cattle-, pig, and poultry feed). Schothorst Feed Research B.V., Lelystad, the Netherlands.

Overton, M., Fetrow, J., 2008. Economics of postpartum uterine health. In Proceedings of the 2008 Dairy Cattle Reproduction Council Convention, 7-8 November 2008, Omaha, NE, USA, pp. 39-43.

R_Core_Team, 2016. R: A language and environment for statistical computing. R Foundation for Statistical Computing, Vienna, Austria. https://www.R-project.org.

Raboisson, D., Mounié, M., Maigné, E., 2014. Diseases, reproductive performance, and changes in milk production associated with subclinical ketosis in dairy cows: A meta-analysis and review. J. Dairy Sci. 97, 7547-7563.

Raboisson, D., Mounié, M., Khenifar, E., Maigné, E., 2015. The economic impact of subclinical ketosis at the farm level: Tackling the challenge of over-estimation due to multiple interactions. Prev. Vet. Med. 122, 417-425.

Raizman, E.A., Santos, J.E.P., Thurmond, M.C., 2002. The effect of left displacement of abomasum corrected by toggle-pin suture on lactation, reproduction, and health of Holstein dairy cows. J. Dairy Sci. 85, 1157-1164.

Rajala, P.J., Gröhn, Y.T., 1998. Effects of dystocia, retained placenta, and metritis on milk yield in dairy cows. J. Dairy Sci. 81, 3172-3181.

Rendac, 2015. Kadavertarieven 2015 (Pricelist 2015). Rendac B. V., Son, the Netherlands.

Rutten, C.J., Steeneveld, W., Inchaisri, C., Hogeveen, H., 2014. An ex ante analysis on the use of activity meters for automated estrus detection: To invest or not to invest? J. Dairy Sci. 97, 6869-6887.

Santos, J.E.P., Cerri, R.L.A., Ballou, M.A., Higginbotham, G.E., Kirk, J.H., 2004. Effect of timing of first clinical mastitis occurrence on lactational and reproductive performance of Holstein dairy cows. Anim. Reprod. Sci. 80, 31-45. 
Seegers, H., Fourichon, C., Beaudeau, F., 2003. Production effects related to mastitis and mastitis economics in dairy cattle herds. Vet. Res. 34, 475-491.

Suthar, V.S., Canelas-Raposo, J., Deniz, A., Heuwieser, W., 2013. Prevalence of subclinical ketosis and relationships with postpartum diseases in European dairy cows. J. Dairy Sci. 96, 29252938.

Van Knegsel, A.T.M., van den Brand, H., Dijkstra, J., Tamminga, S., Kemp, B., 2005. Effect of dietary energy source on energy balance, production, metabolic disorders and reproduction in lactating dairy cattle. Reprod. Nutr. Dev. 45, 665-688.

Vellinga, T.V., Blonk, H., Marinussen, M., Van Zeist, W.J., De Boer, I.J.M., 2013. Methodology used in feedprint: a tool quantifying greenhouse gas emissions of feed production and utilization. Wageningen UR Livestock Research, Lelystad, the Netherlands.

Walsh, R.B., Walton, J.S., Kelton, D.F., LeBlanc, S.J., Leslie, K.E., Duffield, T.F., 2007. The effect of subclinical ketosis in early lactation on reproductive performance of postpartum dairy cows. J. Dairy Sci. 90, 2788-2796.

Wilson, D.J., González, R.N., Hertl, J., Schulte, H.F., Bennett, G.J., Schukken, Y.H., Gröhn, Y.T., 2004. Effect of clinical mastitis on the lactation curve: A mixed model estimation using daily milk weights. J. Dairy Sci. 87, 2073-2084.

Wood, P.D.P., 1967. Algebraic model of the lactation curve in cattle. Nature 216, 164-165. 
$\mathbf{1 0 8}$ | Chapter 5

\section{Supplementary material}

\section{Supplementary Material S1}

\section{Cow parameters (part 1)}

Milk production (305 days) $\left(\mathrm{M}_{\mathrm{i}}\right)$ per parity is determined with a normal distribution function

$\mathrm{M}_{\mathrm{i}}=\operatorname{Normal}\left(\mathrm{MEAN}_{\mathrm{mi}}, \mathrm{SD}_{\mathrm{mi}}\right)$

Where

$\mathrm{MEAN}_{\mathrm{mi}}=$ mean milk production $(\mathrm{M})$ in 305 days of cow $\mathrm{i}$,

$\mathrm{SD}_{\mathrm{mi}}=$ standard deviation of milk production of cow $\mathrm{i}$, which was $5.9 \%$ of the mean based on Bruijnis et al. (2010).

Fat-and-protein-corrected milk (FPCM) was estimated per day.

$\mathrm{FPCM}_{\mathrm{id}}=(0.337+0.116 \mathrm{x} \% \mathrm{~F}+0.06 \times \% \mathrm{P}) \times \mathrm{M}_{\mathrm{id}}$

Where

\% $\mathrm{F}(4.36)$ is fat percentage in milk (CRV, 2014)

$\% \mathrm{P}(3.54)$ is protein percentage in milk (CRV, 2014)

Energy requirement for maintenance and milk production of the cow was estimated per day as voeder eenheid melk (VEM), whereas 1 ooo VEM was equivalent to 6.9 MJ of net energy.

$\mathrm{VEM}_{\mathrm{id}}=\left(42.4 \times \mathrm{BW}^{\mathrm{o} .75_{\mathrm{id}}}+442 \times \mathrm{FPCM}_{\mathrm{id}}\right) \times\left(1+\left(\mathrm{FPCM}_{\mathrm{id}}-15\right) \times 0.00165\right)$

where

BW $^{0.75_{\text {id }}}=$ Body weight of cow (i) at day (d)

$\mathrm{FPCM}_{\mathrm{id}}=$ Fat-and-protein-corrected milk of cow (i) at day (d)

Cows received additional VEM for pregnancy (450, 850, 1 500, 2700 during last four months of pregnancy) and parity 1 (660 per day) and parity 2 (330 per day) cows received additional VEM for growth (CVB, 2012). Body weight increased linear per week in parity 1 and 2. 


\section{Dynamic of subclinical ketosis and related diseases (part 2)}

In the model, subclinical ketosis (SCK) and the diseases mastitis, metritis, displaced abomasum, lameness and clinical ketosis occurring in the first 30 days after calving are included. First, cows have a probability ( Psck $_{\mathrm{i}}$ ) based on their parity to get subclinical ketosis $\left(\mathrm{SCK}_{\mathrm{i}}\right)$, and had SCK (1) or not (o).

$\operatorname{SCK}_{\mathrm{i}}=\operatorname{discrete}\left(\{1, \mathrm{o}\} ;\left\{\right.\right.$ Psck $_{\mathrm{i}}, 1-$ Psck $\left.\left._{\mathrm{i}}\right\}\right)$

Second, cows with SCK had an additional probability on a related disease. Cows had an additional probability based on their parity to get one of the following diseases (o): clinical ketosis (CK), mastitis (MAS), metritis (MET), displaced abomasum (DA), lameness (LAM), no extra disease (SCKONLY) (Berge and Vertenten, 2014).

SCKDISEASE $_{\mathrm{i}}=$ discrete $(\{$ SCKONLY, SCKMAS, SCKMET, SCKDA, SCKLAM, SCKCK $\}$;

$\left\{\right.$ Psckonly $_{\mathrm{i}}$, Psckmas $_{\mathrm{i}}$, Psckmet $_{\mathrm{i}}$, Psckda $_{\mathrm{i}}$, Pscklam $_{\mathrm{i}}$, Psckck $\left._{\mathrm{i}}\right\}$ )

Third, cows with SCK could be removed (SCKrem $)_{\mathrm{i}}$. Cows have a probability to get culled (Pcul) or dead (Pdead) or not culled or death (Plife). The probability of each is dependent on parity of the cow and SCKDISEASE.

SCKrem $_{i}=$ discrete $\left(\{C U L\right.$, DEAD, LIFE $\},\left\{\right.$ Pcul $_{i}$, Pdead $_{i}$, Plife $\left.\left._{i}\right\}\right)$

Where

$\mathrm{Pcul}_{\mathrm{i}}=$ probability of cow (i) to get culled

Pdeath $_{i}=$ probability of cow (i) to get dead

Plife $_{i}=1-$ Pcul $_{\text {io }}-$ Pdeath $_{\text {io }}$

\section{Losses due to diseases (part 3)}

All cows with SCK had the same percentage of reduced milk production at day 1-30. Cows with a related disease after SCK also had after day 30 a reduced milk production for a period which was diseases specific. Total milk losses because of reduced milk production (ML) were summed.

$M_{i}=M_{i d} x \operatorname{MLTP}+M_{i d} \times M_{\text {id }}$

Where

$\mathrm{M}_{\mathrm{id}}=$ milk production of cow (i) on day (d)

MLTP $=\%$ milk production losses of cow (i) with SCK per day on day 1-30

$\mathrm{MLO}_{\mathrm{id}}=\%$ milk production losses of cow (i) with related disease per day (d) after day 30

Cows with a related disease after SCK were treated and the milk during these days was discarded. Milk discarded (Mmd) were summed to estimate the total. 
110 | Chapter 5

$\mathrm{Mmd}_{\mathrm{i}}=\mathrm{M}_{\mathrm{id}} \mathrm{x}(1-\mathrm{MLTP}) \times$ Dwith $_{\mathrm{d}}$

Where

Dwith $_{d}=$ the withdrawal of milk due to treatment of disease at day $(d)(1,0)$

Milk production losses due to removal (MLrem) were estimated as the difference between the milk production of the cow without SCK and the milk production of the removed cow during the first 30 days plus the milk production of the new heifer.

\section{References}

Berge, A.C., Vertenten, G., 2014. A field study to determine the prevalence, dairy herd management systems, and fresh cow clinical conditions associated with ketosis in western European dairy herds. J. Dairy Sci. 97, 2145-2154.

Bruijnis, M.R.N., Hogeveen, H., Stassen, E.N., 2010. Assessing economic consequences of foot disorders in dairy cattle using a dynamic stochastic simulation model. J. Dairy Sci. 93, 2419-2432.

CRV 2014. Jaarstatistieken 2014 voor Nederland (Annual statistics 2014). CRV, Arnhem, the Netherlands.

CVB 2012. Tabellenboek veevoeding 2012, voedernormen landbouwhuisdieren en voederwaarde veevoeders (Composition and nutritional values of feedstuffs and requirement values), CVB-reeks nr.50, August 2012. Productschap Diervoeder, Den Haag, the Netherlands. 


\section{Chapter 6}

\section{General discussion}

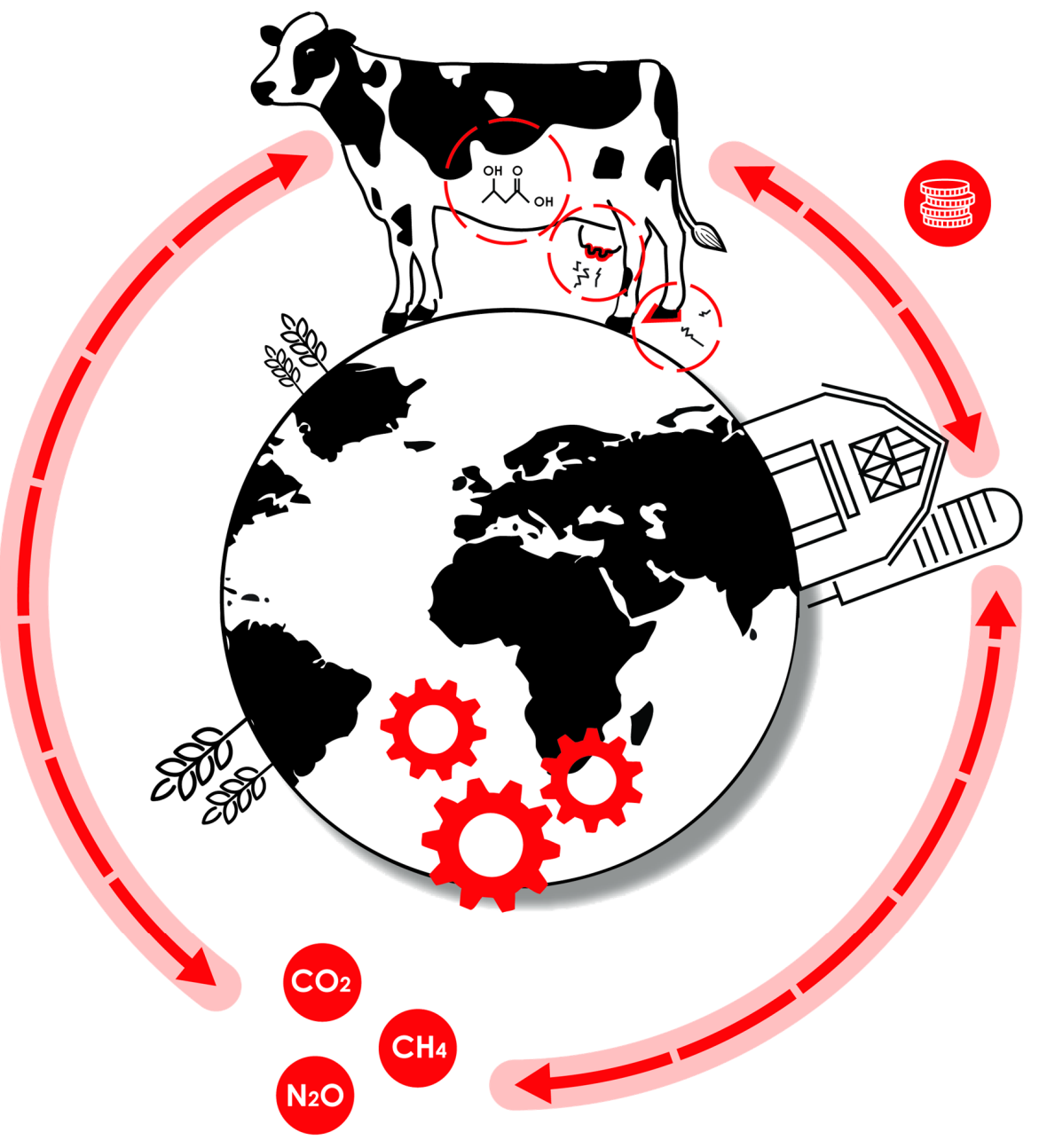


112 | Chapter 6

\section{Introduction}

It is generally acknowledged that future dairy farming should be economically viable, societally acceptable, and environmentally sound. Of these three pillars of sustainability, environmental sustainability is increasingly seen as the most important pillar, because without a life support system, societies and economies cannot thrive (Fischer et al., 2007). A major environmental challenge is global warming, induced by greenhouse gas (GHG) emissions from human activities. The increasing attention for global warming might eventually result in policies to reduce GHG emissions from the food sector, including the dairy sector. Several strategies have been analysed to reduce GHG emissions per kg milk, including feeding, breeding, and management strategies (Van Middelaar et al., 2014; Van Zanten et al., 2014). So far, however, little attention has been given to the impact of diseases on GHG emissions. Reducing diseases in dairy cows can reduce GHG emissions, and several studies showed that this also can increase the income of farmers (Bruijnis et al., 2012; Liang et al., 2017; van Soest et al., 2016). Moreover, reducing diseases can improve the welfare of dairy cows and, therefore, can potentially have a positive impact on all three pillars of sustainability.

The objectives of this thesis were to estimate the impact of diseases in dairy cows on GHG emissions and to understand the relation between the impact of diseases on GHG emissions and economic performance. In this chapter, first methodological choices and challenges are discussed. Subsequently, the objectives of this thesis are answered and discussed. Finally, practical implications and conclusions are presented.

\section{Methodological choices and challenges}

An integrated model was developed to estimate the impact of diseases on GHG emissions and economic performance. Modelling is generally used to analyse the impact of feeding, breeding or management strategies on GHG emissions and economic performance. Real-life experiments that estimate the impact of diseases on GHG emissions and economic performance are complex and costly, as a large amount of diverse data from many different farms are needed. Such real-life experiments should yield data on, for example, the prevalence of diseases and their impact on milk production, fertility, culling rate of cows, farm management (e.g. feed, manure), and measurements of GHG emissions over multiple years. Several studies in literature analysed these above-mentioned aspects separately, and by combining these data in an integrated model, the 
impact of diseases on the economic performance and GHG emissions of a dairy farm can be estimated.

A common method to estimate the impact of diseases on the economic performance is dynamic stochastic modelling. This method integrates the dynamics of diseases and production of a cow over time with an economic analysis (Dijkhuizen et al., 1997), and has proven valuable to identify key production parameters to improve the economic performance of dairy farms (Bruijnis et al., 2010; Huijps and Hogeveen, 2007). This approach was adapted and extended with a GHG analysis. To this end, first a dynamic stochastic simulation model was developed to estimate production losses associated with diseases (Chapter 2, 3, 4). To quantify the impact of these production losses on GHG emissions, this production model was combined with a life cycle assessment (Chapter 2, 3, 4). Finally, an economic analysis (Chapter 5) was added to estimate the costs of subclinical ketosis and to enable the exploration of trade-offs and synergies between GHG emissions and economic performance. Such an integrated model consists of many processes and is difficult to validate in real-life. It is important, therefore, to perform sensitivity analyses, to identify which parameters have a large impact on the final results (see Chapters 2, 3, 4, and 5).

A dynamic stochastic model, moreover, provides insight into the variation of the impact of diseases on GHG emissions and economic performance. The few studies that assessed the impact of diseases on GHG emissions so far (Chen et al., 2016; Hospido and Sonesson, 2005; Özkan Gülzari et al., 2018; Williams et al., 2015) did not gain insight into the variation in results. They only obtained the average impact and included scenarios. Not taking into account variation in results is an oversimplification of conditions under which decisions have to be made in reality (Dijkhuizen et al., 1997). This thesis showed that there was a lot of variation in the impact of diseases on GHG emissions (Chapter 2, 3, 4). The variation (5-95 percentiles) of increase in GHG emissions ranged between 3 and $71 \mathrm{~kg} \mathrm{CO} 2 \mathrm{e} / \mathrm{t}$ fat-and-protein-corrected milk (FPCM) per case of foot lesions, between 18 and $174 \mathrm{~kg} \mathrm{CO}_{2} \mathrm{e} / \mathrm{t} \mathrm{FPCM}$ per case of clinical mastitis, and between 7 and $48 \mathrm{~kg} \mathrm{CO}_{2} \mathrm{e} / \mathrm{t}$ FPCM per case of subclinical ketosis. On average the increase in GHG emissions was $14 \mathrm{~kg} \mathrm{CO}_{2} \mathrm{e} / \mathrm{t}$ FPCM per case of foot lesions, $58 \mathrm{~kg} \mathrm{CO}_{2} \mathrm{e} / \mathrm{t}$ FPCM per case of clinical mastitis, and $21 \mathrm{~kg} \mathrm{CO}_{2} \mathrm{e} / \mathrm{t}$ FPCM per case subclinical ketosis. Including this variation showed that, for example, on average the increase in GHG emissions associated with foot lesions might be minor, but that for some cows the GHG impact is higher. Therefore, including variation gives a better insight into the impact of diseases on GHG emissions, implying that better decisions about treatment of the cow can be made. 
The above-mentioned studies (Chen et al., 2016; Hospido and Sonesson, 2005; Özkan Gülzari et al., 2018; Williams et al., 2015), moreover, did not distinguish between parity of cows, include different pathogens and dynamics of diseases, nor analysed the effects of different production parameters (e.g. culling, reproduction) per type of disease. The importance of including these aspects is described below.

All chapters of this thesis showed that the impact of diseases on GHG emissions or economic performance differ between parities. Grouping parity can result in an over- or underestimation of the impact of diseases. For example, in Chapter 4 is demonstrated that the average impact per case of white line disease on GHG emissions is $39 \mathrm{~kg} \mathrm{CO}_{2} \mathrm{e} / \mathrm{t} \mathrm{FPCM}$, while this is $59 \mathrm{~kg} \mathrm{CO}_{2} \mathrm{e} / \mathrm{t} \mathrm{FPCM}$ for parity 1 cows and $6 \mathrm{~kg} \mathrm{CO}$ e/t FPCM for parity 5 cows. Strategies to reduce diseases, e.g. additional foot trimming, can have costs and can increase GHG emissions. On average, such a strategy might be costs or GHG emissions effective, but this might not hold for each parity. By including the impact of diseases for several parities better decisions about treatment of the disease per cow can be made.

Availability of data about relations between different diseases per parity, however, is limited. Most modelling studies, therefore, are unable to include these relations for different parities, and only distinguish primi- and multiparous cows. Berge and Vertenten (2014) estimated the risk of subclinical ketosis and related diseases for different parities, and therefore these data were used in our model, as described in Chapter 2 and 5 .

In all chapters, data on the reduction in milk production and fertility rate associated with diseases were available for primi- and multiparous cows only, and therefore the effect of these reductions were assumed to be similar for multiparous cows (parity 2 to parity 5). Culling and death rates (together called removal of dairy cows), however, were available per parity. The impact of diseases on milk production, reproduction, or removal of dairy cows were obtained from different studies and subsequently combined in the model. Because the quantification of these production contributors came from different studies, possible interactions between these production contributors could not be included. This might have affected the impact of diseases on production contributors and resulted in an over- or underestimation. Moreover, several studies found or suggested a relation between a higher milk yield and a higher risk of foot lesions, clinical mastitis, and subclinical ketosis (Huxley, 2013; Schukken et al., 2009; Vanholder et al., 2015). Better and more specific data about the impact of diseases on milk production, fertility, and removal per parity could improve estimations per parity. Further research may focus on the impact of breeding for a 
lower milk yield and consequently lower risk of diseases, and the impact of this on GHG emissions and economic performance.

Chapter 3 and 4 of this thesis showed that the impact of diseases on GHG emissions differ per type of pathogen and type of foot lesion. Analysing clinical mastitis and foot lesions without distinguishing type of pathogen or type of foot lesion, can result in an over- or underestimation of the impact of diseases. The increase in GHG emissions per case of clinical mastitis, for example, varied between the types of pathogens. When the first infection was caused by gram-negative bacteria, GHG emissions increased by $65 \mathrm{~kg} \mathrm{CO}_{2} \mathrm{e} / \mathrm{t} \mathrm{FPCM}$, whereas when this first infection was caused by gram-positive bacteria or another pathogen this increase was only $54 \mathrm{~kg} \mathrm{CO}_{2} \mathrm{e} / \mathrm{t} \mathrm{FPCM}$, and $51 \mathrm{~kg} \mathrm{CO} 2 \mathrm{e} / \mathrm{t}$ FPCM respectively. Similarly, emissions of GHGs increased on average by only 4 $\mathrm{kg} \mathrm{CO} 2 \mathrm{e} / \mathrm{t}$ FPCM per case of digital dermatitis, but by $39 \mathrm{~kg} \mathrm{CO}_{2} \mathrm{e} / \mathrm{t}$ FPCM per case of white line disease, and by $33 \mathrm{~kg} \mathrm{CO}_{2} \mathrm{e} / \mathrm{t}$ FPCM per case of sole ulcer. Analysing the impact on GHG emissions per type of pathogen and per type of foot lesion provides better insight and can result in better decisions about treatment of the cow.

Most diseases, moreover, have a relation with other diseases. In Chapter 2 and 5, the relations between subclinical ketosis and other diseases were included. The strength of these relations, however, varies in literature (Raboisson et al., 2014), and therefore results in uncertainty of the results. Sensitivity analyses in Chapter 2 and 5 showed that the strength of the relation especially between subclinical ketosis and metritis, and subclinical ketosis and displaced abomasum had an important impact on the results. Increasing the risk ratio of metritis for cows with subclinical ketosis from 1.4 to 3.3 , for example, increased GHG emissions by $13 \%$ per case of subclinical ketosis. Similarly, increasing the risk ratio of displaced abomasum for cows with subclinical ketosis from 3.7 to 8.0, increased GHG emissions by 7\% per case of subclinical ketosis. In Chapter 3 and 4, the relations between subclinical and clinical mastitis, between subclinical and clinical foot lesions were not included because of lack of data. Better data and more specific data about the relations between diseases can improve the estimation of the impact on GHG emissions per combination of diseases.

Production contributors of diseases that were included to estimate the impact on GHG emissions and economic performance are removal of cows, reduced milk production, discarded milk, and prolonged calving interval. Previous studies about the impact of diseases on GHG emissions did not estimate the impact per production contributor, and therefore were not able to identify key parameters that contributed to the increase in GHG emissions. 
From a GHG emissions perspective, removal was an important contributor. Removal, however, is a complex issue to include in economic or GHG emissions models. Several models have been developed to estimate the optimal time of replacement of dairy cows from an economic perspective (Cabrera, 2012; Groenendaal et al., 2004; Houben et al., 1994). As such models do not exist for GHG emissions, a basic method used in economic modelling was adopted to assess the GHG emissions associated with removal. This method depreciates the difference in opportunity costs or GHG emissions of raising a heifer and the meat value of the removed cow over the life time milk production of that cow, and is explained in more detail in Chapter 2 and 5. Developing a specific method to assess the GHG emissions associated with removal would need a $\mathrm{PhD}$ trajectory on itself and, therefore, was excluded from this thesis. Specific models to estimate the optimal time of replacement of cows from a GHG emissions perspective could improve the estimation of removal and help farmers to make removal decisions from a GHG emissions perspective. In addition, removal models from a GHG emissions perspective can show trade-offs and synergies with removal decisions from an economic perspective.

The dynamic stochastic model simulates one lactation of a cow. This means that the average increase in GHG emissions is computed for a given herd composition, in this case the Dutch herd, and therefore the impact of diseases on GHG emissions accounts for this herd composition only. A disease, however, can have an impact across lactations. A diseased cow, for example, has a higher risk of removal. A decrease in diseases prevalence in the herd, therefore, results in a relatively older average age of the herd, which has two effects on the impact of diseases on GHG emissions over multiple years. First, milk production increases with age, and consequently milk production of the herd will increase. Second, a lower removal rate results in rearing less heifers, and less culled cows per year, implying that more calves per year will go to veal or beef production. After multiple years, this increased average age of the herd results in a different milk and meat output. The impact of these phenomena on GHG emissions can be analysed using a herd model, which requires data about interactions between diseases in multiple lactations, which are currently lacking. In summary, having the same reduction in diseases in consecutive years, results in a yearly different age of the herd, and therefore in a yearly different impact of diseases on GHG emissions.

In the model, only processes that were affected by diseases were included in the estimation of GHG emissions. Emissions of GHGs are generally expressed per kg milk, or per kg or ton FPCM. In this thesis, GHG emissions vary from 0.9-1.o $\mathrm{CO}_{2} \mathrm{e}$ per kg FPCM, which are in accordance with values found in literature (De Vries and de Boer, 2010). 


\section{Impact of diseases on GHG emissions}

To estimate the impact of diseases in dairy cows on GHG emissions, the impact of the main diseases in dairy cattle was assessed separately, as described in various chapters (i.e. subclinical ketosis, clinical mastitis, and foot lesions). In this section, first the impact of the production contributors on the increase in GHG emissions is compared across diseases. Subsequently, the impact of the combination of all diseases on GHG emissions per year are presented at interlinked levels, i.e. cow, herd and country.

\section{Impact of production contributors of diseases on the increase in GHG emissions}

The impact of production contributors on the increase in GHG emissions differ for subclinical ketosis, clinical mastitis, and foot lesions. Production contributors with the highest impact were discarded milk and prolonged calving interval for subclinical ketosis, removal and discarded milk for clinical mastitis, prolonged calving interval for digital dermatitis, culling for white line disease, and culling and reduced milk production for sole ulcer. The importance of production contributors highly depends on the effects of the diseases on these production contributors.

If cows, for example, have an increased risk of removal then removal is an important production contributor for the increase in GHG emissions. The contribution of removal to the increase in GHG emissions was on average $69 \%$ for white line disease, $52 \%$ for SU, and $39 \%$ for clinical mastitis. For cows with subclinical ketosis this contribution was lower (20\%), because the risk of removal was lower for these cows. GHG emissions of cows with subclinical ketosis that were culled, however, increased on average by $188 \mathrm{~kg} \mathrm{CO}_{2} \mathrm{e} / \mathrm{t}$ FPCM, and of cows that died by $463 \mathrm{~kg} \mathrm{CO}_{2} \mathrm{e} / \mathrm{t}$ FPCM. Therefore, also removal of cows with subclinical ketosis should be avoided to prevent an additional impact on GHG emissions.

If cows were treated with antibiotics, discarded milk was an important production contributor for the increase of GHG emissions. The contribution of discarded milk to the increase in GHG emissions was highest for clinical mastitis, i.e. on average $38 \%$. This does not mean that cows should not be treated to reduce GHG emissions. Not treating cows would negatively affect the welfare of the cows. Moreover, not treating might result in removal of cows, which will eventually result in a higher increase in GHG emissions. Therefore, preventing clinical mastitis or finding solutions to recover from clinical mastitis without using antibiotics will help to reduce the amount of discarded milk and hence GHG emissions per kg FPCM. 
The impact of a prolonged calving interval on the increase in GHG emissions was low for cows with clinical mastitis, white line disease, and sole ulcer. The contribution of prolonged calving interval to the increase in GHG emissions was highest for subclinical ketosis and digital dermatitis, i.e. on average $36 \%$ and $82 \%$ respectively. This can be explained by two factors. First, subclinical ketosis and digital dermatitis had a lower impact on other production contributors, such as removal, reduced milk production, and discarded milk than the other diseases. This results in a lower total impact, and consequently a relatively higher contribution from prolonged calving interval to the total impact. Second, calving interval increased most for cows with subclinical ketosis and, therefore, it had a relatively high impact on increase in GHG emissions. The impact of prolonged calving interval of cows with subclinical ketosis $\left(6 \mathrm{~kg} \mathrm{CO}_{2} \mathrm{e} / \mathrm{t} \mathrm{FPCM}\right)$ and digital dermatitis (3 $\mathrm{kg}$ $\mathrm{CO}_{2} \mathrm{e} / \mathrm{t}$ FPCM) seems to be less important, when compared to, for example, the impact of removal of cows due to clinical mastitis (23 $\mathrm{kg} \mathrm{CO}_{2} \mathrm{e} / \mathrm{t}$ FPCM). Removal because of a prolonged calving interval was not included, and therefore the impact of prolonged calving might be underestimated. It can be concluded based on this thesis, however, that the impact of a prolonged calving interval on GHG emissions is minor and less important than the impact of other production contributors. The production contributor reduced milk production increased GHG emissions of all the diseases. The contribution of reduced milk production to the increase in GHG emissions was on average $48 \%$ for sole ulcers. For other diseases, however, other production contributors were more important. Therefore, it can be concluded that reduced milk production is less important to the increase in GHG emissions than other production contributors, such as removal and discarded milk.

In summary, removal and discarded milk are the production contributors with the highest increase in GHG emissions. Prevalence, pathogen types, and farm management (e.g. culling, feed, and manure) affect the impact of production contributors on the increase in GHG emissions. Therefore, specific farm analyses are needed to estimate of impact of diseases on GHG emissions for a specific dairy farm. 


\section{The impact of diseases on GHG emissions at interlinked levels}

In Chapter 2, 3, and 4, the increase in GHG emissions was estimated in $\mathrm{kg} \mathrm{CO}_{2} \mathrm{e} / \mathrm{t} \mathrm{FPCM}$. Analysing the impact of diseases per $\mathrm{kg} \mathrm{CO}_{2} \mathrm{e} / \mathrm{t}$ FPCM shows the effect on efficiency of milk production. This enables a comparison with other mitigation strategies to reduce GHG emissions, but does not show the absolute increase or decrease in GHG emissions per year. The impact of diseases on annual milk production differs per type of disease. To analyse and compare the impact of different diseases on GHG emissions per year on cow, herd, and national level, additional calculations were performed (see for a detailed explanation box 1).

\section{Box 1}

The impact of diseases on GHG emissions was estimated on cow, herd, and national level (i.e. the Netherlands). Milk production of cows affected by the diseases expressed in fat-and-proteincorrected milk per year (actual FPCM per year) were estimated on cow level. The potential (not affected by diseases) and actual (affected by diseases) GHG emissions $\left(\mathrm{kg} \mathrm{CO}_{2} \mathrm{e} / \mathrm{t} \mathrm{FPCM}\right)$ of cows were obtained from Chapter 2, 3, and 4. On cow level, the additional GHG emissions per year per case of subclinical ketosis, clinical mastitis, digital dermatitis, white line disease, and sole ulcer were computed as follows:

actual FPCM per year x ( $\mathrm{kg} \mathrm{CO}_{2} \mathrm{e} / \mathrm{kg}$ FPCM actual - $\mathrm{kg} \mathrm{CO}_{2} \mathrm{e} / \mathrm{kg}$ FPCM potential) [1]

To compute GHG emissions on herd level, an average Dutch dairy herd of 100 cows was assumed. To estimate the number of affected cows in a herd level, average herd prevalence for each disease was derived from literature and the models of Chapter 2, 3, and 4. Subsequently, the GHG impact on herd level per year was computing by multiplying the impact on cow level (equation 1) with the number of affected cows on herd level. On national level, all dairy cows in the Netherlands $(1,742,660 ; \mathrm{CRV}, 2016)$ were included. The number of cows affected by diseases on national level was estimated assuming similar average disease prevalence as on herd level. Subsequently, the GHG impact on national level per year was computed by multiplying the impact on cow level (equation 1) with the number of affected cows on national level.

On cow level, GHG emissions increase by $176 \mathrm{~kg} \mathrm{CO}_{2} \mathrm{e} /$ year per case of subclinical ketosis, by 498 $\mathrm{kg} \mathrm{CO} 2 \mathrm{e} /$ year per case of clinical mastitis, by $30 \mathrm{~kg} \mathrm{CO}_{2} \mathrm{e} /$ year per case of digital dermatitis, by $336 \mathrm{~kg} \mathrm{CO} \mathrm{C}_{2} \mathrm{e}$ year per case of white line disease, and by $280 \mathrm{~kg} \mathrm{CO}_{2} \mathrm{e} /$ year per case of sole ulcer 
120 | Chapter 6

(Table 1). The differences in increase of GHG emissions for diseases are explained by different FPCM per year and efficiency in GHG emissions ( $\mathrm{kg} \mathrm{CO}_{2} \mathrm{e} / \mathrm{kg}$ FPCM). It can be concluded that on cow level clinical mastitis, followed by white line disease, has the highest increase in GHG emissions per year.

On herd level, subclinical ketosis increases GHG emissions by 4,398 $\mathrm{kg} \mathrm{CO}_{2} \mathrm{e} /$ year, clinical mastitis by $12,959 \mathrm{~kg} \mathrm{CO}_{2} \mathrm{e} /$ year, digital dermatitis by $640 \mathrm{~kg} \mathrm{CO}_{2} \mathrm{e} /$ year, white line disease by $1,480 \mathrm{~kg}$ $\mathrm{CO}_{2} \mathrm{e} /$ year, and sole ulcer by $1,495 \mathrm{~kg} \mathrm{CO}_{2} \mathrm{e} /$ year (Table 1). It can be concluded that on herd level clinical mastitis, has the highest increase in GHG emissions per year. Although subclinical ketosis has a lower increase in GHG emissions on cow level, on herd level it has the highest increase in GHG emissions after clinical mastitis because of the high prevalence on herd level. This, however, might differ per farm, and therefore specific farm analyses are needed to reduce the GHG emissions for that farm.

Table 1. Prevalence (\%) and impact of diseases on fat-and-protein-corrected milk (FPCM) and greenhouse gas emissions $\left(\mathrm{kg} \mathrm{CO}_{2} \mathrm{e}\right)$ per year on cow, herd, and country level (the Netherlands).

\begin{tabular}{lcrrrrrrr}
\hline & Herd & \multicolumn{2}{c}{$\mathrm{kg} \mathrm{FPCM} / \mathrm{cow} /$ year } & \multicolumn{2}{c}{$\mathrm{kg} \mathrm{CO}_{2} \mathrm{e} / \mathrm{t} \mathrm{FPCM}$} & \multicolumn{2}{c}{ Additional $\mathrm{CO}_{2} \mathrm{e} /$ disease/year } \\
Disease & $\%$ & Potential & Actual & Potential & Actual & $\mathrm{kg} / \mathrm{case} / \mathrm{cow}$ & $\mathrm{kg} / \mathrm{herd}$ & Mton/national \\
\hline Subclinical ketosis & 25.0 & 8,800 & 8,417 & 923 & 944 & 176 & 4,398 & 0.076 \\
Clinical mastitis & 26.0 & 9,266 & 8,668 & 922 & 979 & $498^{1}$ & 12,959 & 0.226 \\
Digital dermatitis & 21.5 & 8,624 & 8,513 & 924 & 927 & 30 & 640 & 0.011 \\
White line disease & 4.4 & 8,684 & 8,539 & 923 & 962 & 336 & 1,480 & 0.026 \\
Sole ulcer & 5.3 & 8,875 & 8,535 & 920 & 953 & 280 & 1,495 & 0.026 \\
\hline
\end{tabular}

${ }^{1}$ The weighted average of one, two, and three cases of clinical mastitis

In the Netherlands (national level), subclinical ketosis increases GHG emissions by 0.08 Mton

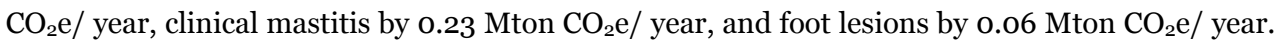

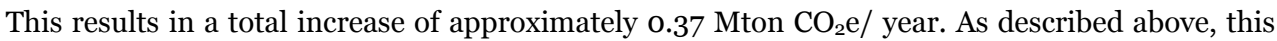
includes the interaction of subclinical ketosis with other diseases, but excludes the interactions of other diseases. Including also other diseases, e.g. displaced abomasum or metritis, and interactions will result in a higher impact of diseases on GHG emissions. In an ideal situation where cows do not have diseases, the same amount of milk could be produced in the Netherlands with a dairy cow population with approximately 60,000 heads less than the current population. It can be concluded therefore that reducing diseases will decrease GHG emissions on cow, herd, and national level. Clinical mastitis has on average the highest impact on the increase in GHG emissions on cow, herd, and national level, and therefore reducing clinical mastitis can cause the highest reduction in GHG emissions. 


\section{Impact of diseases: comparing GHG emissions with economic performance}

This thesis is the first that estimated the impact of different production contributors of diseases on GHG emissions. Exploring the impact of different production contributors on the economic performance, however, is common in economic analyses. Because this thesis addresses both a GHG and economic analysis of diseases, final results can be compared, and synergies and trade-offs between impact of diseases on GHG emissions and economic performance can be explored. To demonstrate the differences in impact of diseases on GHG emissions and economic performance, first, the impact of production contributors on GHG emissions and economic performance is compared. Second, the total impact on GHG emissions and economic performance is compared.

\section{Impact of production contributors affected by subclinical ketosis on GHG emissions and economic performance}

The impact of subclinical ketosis on GHG emissions and economic performance is estimated in Chapter 2 and 5, and results of these chapters are used to compare the impact of production contributors on GHG emissions and economic performance. The impact of diseases on GHG emissions, is expressed in $\mathrm{kg} \mathrm{CO}_{2} \mathrm{e}$ per case per year, whereas the economic performance is expressed in costs $(€)$ per case per year.

All production contributors increased GHG emissions and costs (Table 2). No trade-offs were found between the production contributors. Prolonged calving interval had the highest impact from a GHG emissions and economic perspective. Production contributors, however, are not equally important from a GHG emissions and economic perspective. The relative importance of reduced milk production and prolonged calving interval was higher for costs than for GHG emissions, whereas the relative importance of removal and discarded milk was higher for GHG emissions than for costs. 
Table 2. Impact of subclinical ketosis on economic performance ( $€ /$ case) and increase in greenhouse gas emissions $\left(\mathrm{kg} \mathrm{CO}_{2} \mathrm{e} /\right.$ case) per year, related to different production contributors and the relative contribution (\%).

\begin{tabular}{lrrrr}
\hline Production contributor & $€ /$ case & $\%$ & $\mathrm{~kg} \mathrm{CO}_{2} \mathrm{e} / \mathrm{case}$ & $\%$ \\
\hline Reduced milk production & 32 & 24 & 34 & 19 \\
Discarded milk & 18 & 14 & 52 & 30 \\
Treatment & 25 & 19 & 35 & 20 \\
Removal & 8 & 6 & 55 & 31 \\
Prolonged calving interval & 46 & 36 & 176 & 100 \\
\hline Total & 130 & 100 & & \\
\hline
\end{tabular}

Reduced milk production and prolonged calving interval resulted in a higher energy requirement per $\mathrm{kg}$ of milk produced and consequently reduced feed efficiency ( $\mathrm{kg}$ feed/kg milk). The margin over feed for producing an extra kg of milk was higher from an economic perspective than from a GHG emissions perspective. Therefore, reduced milk production had a higher impact on the economic performance than on GHG emissions. Milk and feed price, however, had an important impact on the margin over feed and consequently to the contribution of reduced milk production on costs. Sensitivity analyses in Chapter 5 for example showed that increasing the milk price to $€ 0.42 / \mathrm{kg}$ (i.e. increased margin over feed), increased the costs of subclinical ketosis by $20 \%$.

Removal had a higher impact on the increase in GHG emissions than on economic performance. Two factors were important for the contribution of removal. First, the risk of removal has an important impact to the contribution of removal. Doubling the probability of removal increased the impact of subclinical ketosis on GHG emissions by $16 \%$. Second, the opportunity costs of rearing a heifer were also an important contributor to the impact of removal on GHG emissions and economic performance. Chapter 5 showed that depreciation costs of the total costs of rearing a new heifer were $25 \%$, whereas Chapter 2 showed that these were $59 \%$ for GHG emissions.

Discarded milk had a higher impact on the increase in GHG emissions than on the economic performance. Discarded milk had the same impact on efficiency of milk production ( $\mathrm{kg}$ feed $/ \mathrm{kg}$ milk) from GHG emissions and economic perspective. However, the total impact of subclinical ketosis was higher from an economic perspective (due to higher impact other production contributors) than from a GHG emissions perspective. Therefore, the contribution of discarded milk was lower from an economic perspective. 


\section{Impact production contributors affected by clinical mastitis on GHG emissions and economic performance}

Chapter 3 describes the impact of clinical mastitis on GHG emissions. The economic impact of clinical mastitis, however, was not estimated in this thesis. Therefore, a study of van Soest et al. (2016) that estimated the economic impact of clinical mastitis in the Netherlands is used here. Milk price had an high impact on relative importance of production contributors in van Soest et al. (2016), and therefore two milk prices (€o.31 and €0.41/ kg milk) are used in this section.

All production contributors increased GHG emissions and costs (Table 3). No trade-offs were found between the production contributors. Reduced milk production had the highest impact on economic performance, whereas removal had the highest impact on increase in GHG emissions. Comparing the production contributors showed a similar effect as found by subclinical ketosis. For clinical mastitis, independent of milk price, the relative importance of reduced milk production was higher for costs than for GHG emissions, whereas the relative importance of removal and discarded milk was higher for GHG emissions than for costs (Table 3).

Table 3. Impact of clinical mastitis on economic performance ( $€ /$ case) with different milk prices $\left(€ / \mathrm{kg}\right.$ milk) and increase in greenhouse gas emissions $\left(\mathrm{kg} \mathrm{CO}_{2} \mathrm{e} /\right.$ case) per year, related to different contributors and the relative contribution (\%).

\begin{tabular}{|c|c|c|c|c|c|c|}
\hline & \multicolumn{2}{|c|}{$€ 0.41 / \mathrm{kg}$} & \multicolumn{2}{|c|}{$€ 0.31 / \mathrm{kg}$} & \multicolumn{2}{|c|}{$\mathrm{Kg} \mathrm{CO}_{2} \mathrm{e}$} \\
\hline & $€ /$ case & $\%$ & $€ /$ case & $\%$ & Case & $\%$ \\
\hline Reduced milk production & 116 & 39 & 85 & 33 & 86 & 17 \\
\hline Discarded milk & 73 & 24 & 59 & 23 & 190 & 38 \\
\hline Veterinary visits & 1 & 1 & 1 & 1 & & \\
\hline Labour & 15 & 5 & 15 & 6 & & \\
\hline Antibiotics & 22 & 7 & 22 & 8 & & \\
\hline Removal & 73 & 24 & 74 & 29 & 193 & 39 \\
\hline Prolonged calving interval ${ }^{1}$ & & & & & 30 & 6 \\
\hline Total & 301 & 100 & 257 & 100 & 498 & 100 \\
\hline
\end{tabular}

Comparing the different production contributors from a GHG emissions and economic perspective without having the same input and same type of model, however, is complex. For example, in Chapter 3 we used an $8 \%$ higher risk of culling than van Soest et al. (2016) and in Chapter 5 we estimated lower costs for removal for subclinical ketosis (Chapter 5) than van Soest et al. (2016). These two factors have an impact on the contribution of removal to the economic performance and GHG emissions. In Chapter 3, cows could get multiple times clinical mastitis resulting on average in more antibiotic use and consequently more discarded milk, and therefore a higher impact of 
discarded milk GHG emissions. The impact of a prolonged calving interval was included in reduced milk production by van Soest et al. (2016). Summing prolonged calving interval and reduced milk production in the GHG emissions analysis, did not affect conclusions.

Some production contributors have a major impact on economic performance but a minor impact on GHG emissions or are excluded. In economic estimations of costs of diseases, costs for medication, extra labour of the farmer, and veterinarian care are generally included. Expressing extra labour and veterinarian care in GHG emissions is complex and the impact of medicine production on GHG emissions is generally assumed to be minor. The exclusion of these three aspects resulted in an underestimation of the total impact of diseases on GHG emissions and the impact of production contributors to the total.

Considering the differences between the analyses of GHG emissions and economic performance, it can be concluded that there are no trade-offs in reducing diseases from a GHG emissions and economic perspective. However, the production contributors are not equally important from a GHG emissions and economic perspective. This thesis showed that reduced milk production has the highest impact on economic performance, whereas removal and discarded milk have the highest impact on increase in GHG emissions. This was also concluded by Kok et al. (2017), who found that from an economic perspective increasing milk yield is more efficient than reducing culling on herd level, whereas from GHG emissions perspective reducing culling is more efficient than increasing milk yield on herd level.

\section{Total impact of subclinical ketosis and clinical mastitis on GHG emissions and economic performance}

The total increase in GHG emissions because of subclinical ketosis and clinical mastitis was estimated in section 6.3 and the impact on efficiency in milk production in Chapter 2, and 4 . The increase in GHG emissions was for subclinical ketosis $176 \mathrm{~kg} \mathrm{CO}_{2} \mathrm{e}$ per case per year, and for clinical mastitis $498 \mathrm{~kg} \mathrm{CO}_{2} \mathrm{e}$ per case per year (Table 2, 3). Subclinical ketosis increased GHG emissions by $2.3 \%$ and clinical mastitis by $6.2 \%$.

The total economic impact of subclinical ketosis and clinical mastitis was estimated in Chapter 5 and by van Soest et al. (2016). The impact of subclinical ketosis and clinical mastitis on efficiency in milk production was estimated based on revenues minus feed costs. Milk production, quantity of feed and milk and feed price determine revenues minus feed costs. It was not possible to completely match the inputs of milk production, and milk and feed price used in the economic estimations of subclinical ketosis and clinical mastitis. This has an impact on the efficiency in milk 
production from an economic perspective, but not from the GHG emissions perspective. The total impact of subclinical ketosis on costs was $€ 130$ (milk price of $€ 0.34 / \mathrm{kg}$ ) per case per year, and of clinical mastitis $€_{257}$ (milk price of $€ 0.31 / \mathrm{kg}$ ) or $€_{301}$ (milk price of $€ 0.41 / \mathrm{kg}$ ) per case per year (Table 2, 3). Revenues minus feed costs, with a milk price of $€ 0.32 / \mathrm{kg}$ milk are estimated at $€ 2,065$ per cow per year, with a milk price of $€ 0.34 / \mathrm{kg}$ at $€ 2,301$ per cow per year, and with a milk price of $€ 0.42 / \mathrm{kg}$ at $€ 2,896$ per cow per year (LEI, 2018). Subclinical ketosis decreased revenues minus feed costs by $5.6 \%$, clinical mastitis by $12.4 \%$ (€0.31/kg milk) and $10.4 \%$ (€0.41/kg milk).

It can be concluded, therefore, that subclinical ketosis and clinical mastitis have proportional larger impacts on economic performance than on GHG emissions.

\section{Practical implications}

The current goal of the Dutch government is to reduce GHG emissions from agriculture by 3.5 Mton, from which 1.0 Mton of horticulture, in 2030. Based on this thesis, diseases in dairy cows increase GHG emissions by approximately 0.4 Mton per year, which is $15 \%$ of this goal. Though using different methodologies, other studies that estimated the impact of diseases on GHG emissions also concluded that diseases in dairy cows increase GHG emissions (Chen et al., 2016; Hospido and Sonesson, 2005; Özkan Gülzari et al., 2018; Williams et al., 2015). Therefore, it can be concluded that reducing diseases in dairy cows can contribute to the goals of the Dutch government. A disease free dairy farm, however, will be hard to realize in reality, but the ranges in prevalence of diseases among farms show that there is quite some potential to reduce diseases on dairy farms. Especially dairy farms with high disease prevalence have a high potential to decrease GHG emissions and increase their economic performance by reducing diseases.

Several strategies have been investigated to reduce diseases in dairy cows. In Chapter 2, 3, 4, and 5 strategies to reduce subclinical ketosis, clinical mastitis, and foot lesions are discussed as well as the costs-effectiveness of these strategies. Strategies that were costs-effective were, for example, washing dirty udders and the use of milkers' gloves to prevent clinical mastitis, or additional foot trimming to prevent foot lesions (Bruijnis et al., 2013b; Hogeveen et al., 2011). The impact of these strategies on GHG emissions, is unknown and therefore, further research may focus on the impact of strategies to reduce diseases on GHG emissions.

Although the benefits of reducing diseases from an economic perspective are well known for many years in the scientific field, farmers have a different perspective or experience difficulties to reduce diseases. While prevalence of foot disorders is high on dairy farms, farmers seem to be satisfied 
with the foot heath status at their farm (Bruijnis et al., 2013a) or do not see this as a top priority (Leach et al., 2010a). Barriers to improve foot health are lack of time, lack of labour, and the long interval for seeing an improvement after an action (Bruijnis et al., 2013a; Leach et al., 2010a, b). A project in the UK aiming to reduce lameness on dairy farms showed that improving detection of lameness can reduce lameness. Moreover, by increasing awareness of lameness, farmers can overcome a self-defined barrier of lack of time (Leach et al., 2013).

The prevalence of clinical mastitis is also high on dairy farms. To improve mastitis management, nonmonetary factors, such as esteem and taking pleasure in healthy animals on the farm, are equally important as monetary factors affecting economic performance (Valeeva et al., 2007). A five year national mastitis programme decreased the incidence rate of clinical mastitis from 33.5 to 28.1 quarter cases per 100 cow years at risk in the Netherlands (Lam et al., 2013). On farm study group meetings were held, education materials for farmers developed, and mass media campaigns were organized on, for instance, the use of milking gloves, timely replacement of teat cup liners, and use of a treatment protocol for antibiotics. After five years results show that e.g. the use of milking gloves increased from 15 to $46 \%$, whereas the use of a standardized mastitis treatment protocol increased from 7 to $34 \%$ (Jansen et al., 2010). Moreover, the costs of mastitis were reduced per farm by $6.5 \%$, making the $€ 8$ million investment of the Dutch dairy industry in the programme costs-effective (Lam et al., 2013).

Creating more awareness of foot lesions and mastitis and showing their negative impact on production by the dairy industry can reduce these diseases. Monitoring and treatment of subclinical ketosis are important because of its high prevalence and associated costs. Several handheld meters and cow-side tests have been tested for detection of subclinical ketosis. Although milk and urine tests are easier for farmers, a blood samples have a better diagnostic performance compared with urine and milk (Bach et al., 2016; Carrier et al., 2004; Iwersen et al., 2009). Monitoring for subclinical ketosis during the dry period or early lactation can prevent other diseases. Other studies (Mahrt et al., 2015; McArt et al., 2015) evaluated the impact of hyperketonemia that includes both subclinical and clinical ketosis. Hyperketonemia assumes that subclinical ketosis and clinical ketosis are the same disease, but with a different severity. Using one term for subclinical and clinical ketosis can make it easier to communicate and create awareness among farmers.

A national disease programme to create more awareness of several diseases could help to reduce diseases. However, it remains questionable who should be responsible for the costs of such a programme. If governments want to reduce antibiotics use and GHG emissions, and increase sustainability of the dairy sector, investing in such a programme could help achieving these goals. 
The current incentive of farmers to reduce diseases because of an increase in GHG emissions might be low. A farmer cannot directly observe an increase or decrease in GHG emissions on their farm. Currently the livestock sector has no regulations on GHG emissions and is not involved in carbon trade. Policies to reduce GHG emissions in the agricultural sector, including the dairy sector, might stimulate farmers to take action. Targets of maximum GHG emissions per kg milk can be set per type of dairy farming system (e.g. conventional, organic) for getting a premium, considering other important aspect of the dairy sector. Others important aspects of the dairy sector, such as breeding dairy cows with specific characteristics, or grazing of dairy cows, can result in higher or lower GHG emissions, and therefore need different targets. To not lose the competitiveness of the Dutch dairy sector and to motivate farmers, specific targets should be rewarded with premiums.

Although not analysed in this thesis, reducing foot lesions, mastitis and subclinical ketosis will most likely also improve animal welfare and decrease other environmental impacts such as acidification potential, eutrophication potential, fossil depletion (Chen et al., 2016; Hospido and Sonesson, 2005) and decrease land use, and use of antibiotics. Therefore reducing diseases can improve the three pillars of sustainability, and can contribute to sustainable development of the dairy sector. 
$\mathbf{1 2 8}$ | Chapter 6

\section{Conclusions}

This thesis estimated the impact of diseases in dairy cows on greenhouse gas emissions and analysed the relation between the impact of diseases on greenhouse gas emissions and economic performance. From this thesis, the following can be concluded:

- Subclinical ketosis, clinical mastitis, and foot lesions in Dutch dairy cows result together in additional greenhouse gas emissions of approximately $0.4 \mathrm{Mton} \mathrm{CO}_{2} \mathrm{e}$ per year.

- Reducing diseases contributes to sustainable development of the dairy sector, because it can reduce greenhouse gas emissions, increase the income of the farmer, and improve animal welfare.

- Diseases in dairy cows have proportional larger impacts on economic performance than on greenhouse gas emissions.

- A reduction in milk production associated with diseases has the highest impact on economic performance, whereas removal and discarded milk have the highest impact on the increase in greenhouse gas emissions.

- Specific farm analyses are necessary to estimate the impact of reducing diseases on greenhouse gas emissions and economic performance for a specific farm.

- Uncertainty of data should be accounted for when communicating results. Better data about disease prevalence, relations between diseases, the impact of diseases on production contributors, greenhouse gas emissions related to feed production and manure management, could improve estimations. 


\section{References}

Bach, K.D., Heuwieser, W., McArt, J.A.A., 2016. Technical note: Comparison of 4 electronic handheld meters for diagnosing hyperketonemia in dairy cows. J. Dairy Sci. 99, 9136-9142.

Berge, A.C., Vertenten, G., 2014. A field study to determine the prevalence, dairy herd management systems, and fresh cow clinical conditions associated with ketosis in western European dairy herds. J. Dairy Sci. 97, 2145-2154.

Bruijnis, M., Hogeveen, H., Garforth, C., Stassen, E., 2013a. Dairy farmers' attitudes and intentions towards improving dairy cow foot health. Livest Sci 155, 103-113.

Bruijnis, M.R.N., Beerda, B., Hogeveen, H., Stassen, E.N., 2012. Assessing the welfare impact of foot disorders in dairy cattle by a modeling approach. Animal 6, 962-970.

Bruijnis, M.R.N., Hogeveen, H., Stassen, E.N., 2010. Assessing economic consequences of foot disorders in dairy cattle using a dynamic stochastic simulation model. J. Dairy Sci. 93, 2419-2432.

Bruijnis, M.R.N., Hogeveen, H., Stassen, E.N., 2013b. Measures to improve dairy cow foot health: consequences for farmer income and dairy cow welfare. Animal 7, 167-175.

Cabrera, V.E., 2012. A simple formulation and solution to the replacement problem: A practical tool to assess the economic cow value, the value of a new pregnancy, and the cost of a pregnancy loss. J. Dairy Sci. 95, 4683-4698.

Carrier, J., Stewart, S., Godden, S., Fetrow, J., Rapnicki, P., 2004. Evaluation and use of three cowside tests for detection of subclinical ketosis in early postpartum cows. J. Dairy Sci. 87, 3725-3735.

Chen, W., White, E., Holden, N.M., 2016. The effect of lameness on the environmental performance of milk production by rotational grazing. J. Environ. Manage. 172, 143-150.

CRV 2016. International Dutch cattle improvement co-operative. Jaarstatistieken 2014 voor Nederland (Annual statistics 2016). CRV, Arnhem, the Netherlands.

De Vries, M., de Boer, I.J.M., 2010. Comparing environmental impacts for livestock products: A review of life cycle assessments. Livest Sci 128, 1-11.

Dijkhuizen, A.A., Jalvingh, A.W., Huirne, R.B.M., 1997. Critical steps in systems simulation, In: A.A. Dijkhuizen and R.S. Morris (Eds) Animal health economics: principles and applications, Post graduate foundation in Veterinary Science, University of Sydney, Sydney South, Australia (1997) 59-68.

Fischer, J., Manning, A.D., Steffen, W., Rose, D.B., Daniell, K., Felton, A., Garnett, S., Gilna, B., Heinsohn, R., Lindenmayer, D.B., MacDonald, B., Mills, F., Newell, B., Reid, J., Robin, L., Sherren, K., Wade, A., 2007. Mind the sustainability gap. Trends Ecol. Evol. 22, 621-624.

Groenendaal, H., Galligan, D.T., Mulder, H.A., 2004. An economic spreadsheet model to determine optimal breeding and replacement decisions for dairy cattle. J. Dairy Sci. 87, 2146-2157. 
Hogeveen, H., Huijps, K., Lam, T., 2011. Economic aspects of mastitis: New developments. N. Z. Vet. J. 59, 16-23.

Hospido, A., Sonesson, U., 2005. The environmental impact of mastitis: a case study of dairy herds. Sci. Total Environ. 343, 71-82.

Houben, E.H., Huirne, R.B., Dijkhuizen, A.A., Kristensen, A.R., 1994. Optimal replacement of mastitic cows determined by a hierarchic Markov process. J. Dairy Sci. 77, 2975-2993.

Huijps, K., Hogeveen, H., 2007. Stochastic modeling to determine the economic effects of blanket, selective, and no dry cow therapy. J. Dairy Sci. 90, 1225-1234.

Huxley, J.N., 2013. Impact of lameness and claw lesions in cows on health and production. Livest Sci 156, 64-70.

Iwersen, M., Falkenberg, U., Voigtsberger, R., Forderung, D., Heuwieser, W., 2009. Evaluation of an electronic cowside test to detect subclinical ketosis in dairy cows. J. Dairy Sci. 92, 26182624.

Jansen, J., van Schaik, G., Renes, R.J., Lam, T.J.G.M., 2010. The effect of a national mastitis control program on the attitudes, knowledge, and behavior of farmers in the Netherlands. J. Dairy Sci. 93, 5737-5747.

Kok, A., van Middelaar, C.E., Mostert, P.F., van Knegsel, A.T.M., Kemp, B., de Boer, I.J.M., Hogeveen, H., 2017. Effects of dry period length on production, cash flows and greenhouse gas emissions of the dairy herd: A dynamic stochastic simulation model. PLoS One 12, e0187101.

Lam, T.J.G.M., van den Borne, B.H.P., Jansen, J., Huijps, K., van Veersen, J.C.L., van Schaik, G., Hogeveen, H., 2013. Improving bovine udder health: A national mastitis control program in the Netherlands. J. Dairy Sci. 96, 1301-1311.

Leach, K.A., Paul, E.S., Whay, H.R., Barker, Z.E., Maggs, C.M., Sedgwick, A.K., Main, D.C.J., 2013. Reducing lameness in dairy herds - Overcoming some barriers. Res. Vet. Sci. 94, 820-825.

Leach, K.A., Whay, H.R., Maggs, C.M., Barker, Z.E., Paul, E.S., Bell, A.K., Main, D.C.J., $2010 a$. Working towards a reduction in cattle lameness: 1. Understanding barriers to lameness control on dairy farms. Res. Vet. Sci. 89, 311-317.

Leach, K.A., Whay, H.R., Maggs, C.M., Barker, Z.E., Paul, E.S., Bell, A.K., Main, D.C.J., 2010b. Working towards a reduction in cattle lameness: 2. Understanding dairy farmers' motivations. Res. Vet. Sci. 89, 318-323.

Liang, D., Arnold, L.M., Stowe, C.J., Harmon, R.J., Bewley, J.M., 2017. Estimating US dairy clinical disease costs with a stochastic simulation model. J. Dairy Sci. 100, 1472-1486.

Mahrt, A., Burfeind, O., Heuwieser, W., 2015. Evaluation of hyperketonemia risk period and screening protocols for early-lactation dairy cows. J. Dairy Sci. 98, 3110-3119.

McArt, J.A.A., Nydam, D.V., Overton, M.W., 2015. Hyperketonemia in early lactation dairy cattle: A deterministic estimate of component and total cost per case. J. Dairy Sci. 98, 2043-2054. 
Özkan Gülzari, ş., Vosough Ahmadi, B., Stott, A.W., 2018. Impact of subclinical mastitis on greenhouse gas emissions intensity and profitability of dairy cows in Norway. Prev. Vet. Med. 150, 19-29.

Raboisson, D., Mounié, M., Maigné, E., 2014. Diseases, reproductive performance, and changes in milk production associated with subclinical ketosis in dairy cows: A meta-analysis and review. J. Dairy Sci. 97, 7547-7563.

Schukken, Y.H., Hertl, J., Bar, D., Bennett, G.J., González, R.N., Rauch, B.J., Santisteban, C., Schulte, H.F., Tauer, L., Welcome, F.L., Gröhn, Y.T., 2009. Effects of repeated grampositive and gram-negative clinical mastitis episodes on milk yield loss in Holstein dairy cows. J. Dairy Sci. 92, 3091-3105.

Valeeva, N.I., Lam, T.J.G.M., Hogeveen, H., 2007. Motivation of dairy farmers to improve mastitis management. J. Dairy Sci. 90, 4466-4477.

Van Middelaar, C.E., Berentsen, P.B.M., Dijkstra, J., van Arendonk, J.A.M., de Boer, I.J.M., 2014. Methods to determine the relative value of genetic traits in dairy cows to reduce greenhouse gas emissions along the chain. J. Dairy Sci. 97, 5191-5205.

van Soest, F.J.S., Santman-Berends, I.M.G.A., Lam, T.J.G.M., Hogeveen, H., 2016. Failure and preventive costs of mastitis on Dutch dairy farms. J. Dairy Sci. 99, 8365-8374.

Van Zanten, H.H.E., Mollenhorst, H., De Vries, J.W., Van Middelaar, C.E., Van Kernebeek, H.R.J., De Boer, I.J.M., 2014. Assessing environmental consequences of using co-products in animal feed. Int. J. Life Cycle Assess. 19, 79-88.

Vanholder, T., Papen, J., Bemers, R., Vertenten, G., Berge, A.C.B., 2015. Risk factors for subclinical and clinical ketosis and association with production parameters in dairy cows in the Netherlands. J. Dairy Sci. 98, 880-888.

Williams, A., J. Chatterton, G. Hateley, A. Curwen, and J. Elliott. 2015. A systems-life cycle assessment approach to modelling the impact of improvements in cattle health on greenhouse gas emissions. Adv. Anim. Biosci. 6(1):29-31. 



\section{Summary}

The world population is expected to grow to about 10 billion in 2050. Feeding this growing population will be an enormous challenge. To supply the future human population with food while sustaining a liveable planet, food should be produced sustainably. One of the most urgent environmental issues is climate change, induced by greenhouse gas (GHG) emissions. The dairy sector is an important contributor to GHG emissions. Important GHGs related to milk production are carbon dioxide $\left(\mathrm{CO}_{2}\right)$, methane $\left(\mathrm{CH}_{4}\right)$, and nitrous oxide $\left(\mathrm{N}_{2} \mathrm{O}\right)$, mainly emitted during feed production, enteric fermentation, and manure management. Given the expected increase in human population, the limited amount of resources, and GHG emissions related to dairy production, production of milk with a low environmental impact is urgent.

Diseases in dairy cows can reduce milk production, feed efficiency, reproduction performance, longevity, and increase the amount of discarded milk. Several studies therefore show that diseases can affect the economic performance of a dairy farm. Little attention, however, has been given to the impact of diseases on GHG emissions. Moreover, diseases impair the welfare of dairy cows. Therefore, reducing diseases can potentially have a positive impact on all three pillars of sustainability. This thesis focuses on three diseases with the highest average prevalence in dairy cows: subclinical ketosis, clinical mastitis, and foot lesions. The impact on GHG emissions is estimated for all diseases, whereas the impact on economic performance is estimated for subclinical ketosis. The objectives of this thesis were to estimate the impact of diseases on GHG emissions, and to understand the relation between impact of diseases on GHG emissions and economic performance.

In Chapter 2, the impact of subclinical ketosis in dairy cows on GHG emissions was estimated. A dynamic stochastic simulation model was developed and combined with life cycle assessment (LCA). This model simulates the dynamics of subclinical ketosis and related diseases (i.e. mastitis, metritis, displaced abomasum, lameness, and clinical ketosis), and the associated production losses (reduced milk production, discarded milk, a prolonged calving interval, and removal (culling or dying on the farm)) per cow during one lactation. Subsequently, an LCA was developed to quantify the impact of subclinical ketosis and related diseases on GHG emissions per ton fat-andprotein-corrected milk ( $\mathrm{kg} \mathrm{CO}_{2}$ equivalents/t FPCM) from cradle to farm gate. Processes included were feed production, enteric fermentation, and manure management. The emissions of GHGs increased on average by 21 (2.3\%) kg CO2e/t FPCM per case of subclinical ketosis, with a range 
between 7 and 48 (5-95 percentiles). This increase in emissions was caused by a prolonged calving interval (31\%), discarded milk (30\%), reduced milk production (19\%), and removal of cows (20\%). Most cows had subclinical ketosis only (61\%); for these cows emissions increased by $8 \mathrm{~kg} \mathrm{CO} 2 \mathrm{e} / \mathrm{t}$ FPCM, whereas emissions of cows that died on farm increased by $463 \mathrm{~kg}$ CO2e/t FPCM. Sensitivity analyses showed that uncertainty of emissions factors and variation of input parameters had a large impact on the results.

The developed method in Chapter 2, was applied in Chapter 3 to estimate the impact of clinical mastitis in dairy cows on GHG emissions. A dynamic stochastic simulation model was developed to simulate the dynamics and losses of clinical mastitis for individual lactations. Pathogens causing clinical mastitis were classified in gram-positive bacteria, gram-negative bacteria, or other. Cows have a risk of a maximum of three cases of clinical mastitis in one lactation. Based on the parity and pathogen combinations, cows had a reduced milk production, discarded milk, prolonged calving interval, and a risk of removal. Using LCA, emissions of GHGs were estimated from cradle to farm gate for processes along the milk production chain that are affected by clinical mastitis. Emissions increased on average by $58(6.2 \%) \mathrm{kg} \mathrm{CO}_{2} \mathrm{e} / \mathrm{t}$ FPCM per case of clinical mastitis, with a range between 18 and 174 (5-95 percentiles). This increase was caused by removal (39\%), discarded milk (38\%), reduced milk production (17\%), and prolonged calving interval (6\%). The GHG emissions increased by $48 \mathrm{~kg} \mathrm{CO}_{2} \mathrm{e} / \mathrm{t}$ FPCM for cows with one case of clinical mastitis, by $69 \mathrm{~kg}$ $\mathrm{CO}_{2} \mathrm{e} / \mathrm{t}$ FPCM for cows with two cases of clinical mastitis, and by $92 \mathrm{~kg} \mathrm{CO}_{2} \mathrm{e} / \mathrm{t}$ FPCM for cows with three cases of clinical mastitis. Sensitivity analyses showed that the risk of removal and emissions related to rearing of heifers had an important effect on the results.

In Chapter 4, the impact of foot lesions in dairy cows on GHG emissions was estimated. A similar dynamic stochastic simulation model was developed as in Chapter 2 and 3 but now to estimate the dynamics of three types of foot lesions (digital dermatitis, white line disease, and sole ulcer) and the associated production losses within one lactation (reduced milk production, prolonged calving interval, and culling). Subsequently, an LCA was performed to estimate the impact of foot lesions on GHG emissions per ton of FPCM ( $\mathrm{kg} \mathrm{CO}_{2} \mathrm{e} / \mathrm{t} \mathrm{FPCM).} \mathrm{GHG} \mathrm{emissions} \mathrm{increased} \mathrm{on} \mathrm{average} \mathrm{by}$ 14 (1.5\%) $\mathrm{kg} \mathrm{CO}_{2} \mathrm{e} / \mathrm{t}$ FPCM per case of foot lesions (i.e. digital dermatitis, white line disease, or sole ulcer, combined), with a range between 3 and 71 (5-95 percentiles). This increase was caused by culling (39\%), reduced milk production (34\%), and prolonged calving (17\%). Emissions of GHGs increased on average by $4(0.4 \%) \mathrm{kg} \mathrm{CO}_{2} \mathrm{e} / \mathrm{t}$ FPCM per case of digital dermatitis, by 39 (4.3\%) kg 
$\mathrm{CO}_{2} \mathrm{e} / \mathrm{t}$ FPCM per case of white line disease, and by 33 (3.6\%) $\mathrm{kg} \mathrm{CO}_{2} \mathrm{e} / \mathrm{t}$ FPCM per case of sole ulcer.

In Chapter 5, the economic impact of subclinical ketosis was estimated. The dynamic stochastic simulation model developed in Chapter 2 was used to estimate production losses. Subsequently costs were estimated related to a reduced milk production, discarded milk, treatment, prolonged calving interval, and removal of cows. The total costs of subclinical ketosis were $€ 130$ per case per year, with a range between $€_{39}$ and $€_{348}$ (5-95 percentiles). Total costs of subclinical ketosis per case per year resulted for $36 \%$ from a prolonged calving interval, $24 \%$ from reduced milk production, $19 \%$ from treatment, $14 \%$ from discarded milk and $6 \%$ from removal. Most cows with subclinical ketosis, however, had subclinical ketosis only (61\%), and costs were $€_{5} 8$ per case per year. Results of the sensitivity analysis showed that disease incidence, removal risk, relations of subclinical ketosis with other diseases and milk price resulted in a high variation of costs of subclinical ketosis.

In Chapter 6, methodological choices and challenges are discussed. The discussion showed the importance of accounting for variation in the model, distinguishing between parity of cows, including different pathogens and dynamics of diseases, and analysing the effects of different production parameters (e.g. culling, reproduction) per type of disease. Better data about disease prevalence, relations between diseases, the impact of diseases on production contributors, GHG emissions related to feed production and manure management, could improve estimations.

In the discussion the impact of the different diseases on GHG emissions per year are compared. A case of subclinical ketosis increased GHG emissions by $176 \mathrm{~kg} \mathrm{CO}_{2} \mathrm{e} /$ year, clinical mastitis by 498 $\mathrm{kg} \mathrm{CO} 2 \mathrm{e}$ / year, digital dermatitis by $30 \mathrm{~kg} \mathrm{CO}_{2} \mathrm{e} /$ year, white line disease by $336 \mathrm{~kg} \mathrm{CO}_{2} \mathrm{e} /$ year, and sole ulcer by $280 \mathrm{~kg} \mathrm{CO}_{2} \mathrm{e} /$ year. Removal and discarded milk are the production contributors with the highest impact on increase in GHG emissions. Prevalence, pathogen type, and farm management (e.g. culling, feed, and manure) also will affect the impact of production contributors on the increase in GHG emissions. Therefore, specific farm analyses are needed to estimate of impact of diseases for a specific dairy farm.

The relation between impact of diseases on GHG emissions and economic performance is discussed in Chapter 6. It is beneficial to reduce diseases from a GHG emissions and economic perspective. Diseases, however, had proportionally larger impacts on economic performance than on GHG emissions. Moreover, the production contributors were not equally important from a GHG emissions and economic perspective. A reduction in milk production had the highest impact on the 
economic performance, whereas removal and discarded milk had the highest impact on increase in GHG emissions.

Chapter 6, furthermore, provides some practical implications to reduce GHG emissions and improve economic performance. The current goal of the Dutch government is to reduce GHG emissions from agriculture by 3.5 Mton, from which 1.o Mton of horticulture, in 2030. Based on this thesis it can be concluded that diseases in dairy cows increase GHG emissions by approximately 0.4 Mton per year, which is $15 \%$ of the Dutch governmental goal. Policies to reduce GHG emissions in the agricultural sector, including the dairy sector, might stimulate farmers to take action. A national programme to create more awareness of several diseases could help to reduce diseases. It remains questionable, however, who should be responsible for the costs of such a programme. Other strategies to reduce GHG emissions are not always costs-effective. Reducing diseases, however, can decrease GHG emissions, increase the income of the farmer, and improve animal welfare. Therefore, reducing diseases contributes to sustainable development of the dairy sector. 


\section{Samenvatting}

De wereldbevolking zal naar verwachting toenemen tot ongeveer 10 miljard mensen in 2050. Deze mensen voorzien van voldoende en goede kwaliteit voedsel zal een enorme uitdaging zijn. Voedselproductie heeft echter ook een effect op het milieu. Een van de meest urgente milieukwesties is klimaatverandering, welke mede veroorzaakt wordt door de uitstoot van broeikasgassen. De zuivelsector draagt wereldwijd voor ongeveer $5 \%$ bij aan de uitstoot van broekasgassen. Belangrijke broeikasgassen met betrekking tot melkproductie zijn koolstofdioxide $\left(\mathrm{CO}_{2}\right)$, methaan $\left(\mathrm{CH}_{4}\right)$ en lachgas $\left(\mathrm{N}_{2} \mathrm{O}\right)$. Deze worden voornamelijk uitgestoten tijdens voerproductie, pensfermentatie en mestmanagement. Gezien de verwachte toename van de wereldbevolking en de bijdrage van de zuivelsector aan de uitstoot van broeikasgassen is de productie van melk met een lage milieu-impact van groot belang.

Ziekten resulteren in een afname van melkproductie, voerefficiëntie, vruchtbaarheid en levensduur van een melkkoe en een toename van de hoeveelheid weggegooide melk als de koe met antibiotica behandeld wordt. Verschillende onderzoeken tonen aan dat ziekten de economische prestaties van een melkveebedrijf beïnvloeden. Er is echter weinig aandacht besteed aan de impact van ziekten op de uitstoot van broeikasgassen. Bovendien tasten ziekten het welzijn van melkkoeien aan. Daarom kan het verminderen van ziekten mogelijk een positief effect hebben op meerdere aspecten van duurzaamheid. Dit proefschrift richt zich op de drie ziekten met de hoogste gemiddelde prevalentie bij melkkoeien: subklinische ketose, klinische mastitis en klauwaandoeningen. De impact van deze drie ziekten op de uitstoot van broeikasgassen en de economische gevolgen van subklinische ketose worden berekend. Het doel van dit proefschrift is om de impact van ziekten bij melkkoeien op de uitstoot van broeikasgassen te bepalen en om de relatie tussen de impact van ziekten op uitstoot van broeikasgassen en de economische gevolgen van ziekten te analyseren.

In Hoofdstuk 2 is de impact van subklinische ketose bij melkkoeien op de uitstoot van broeikasgassen geanalyseerd. Een dynamisch, stochastisch, simulatiemodel is ontwikkeld en gecombineerd met een levenscyclusanalyse (LCA). Dit model simuleert eerst het effect van subklinische ketose en gerelateerde ziekten (bijv. mastitis, metritis, lebmaagverplaatsing, klauwaandoeningen en klinische ketose) op de bijbehorende productieverliezen (verminderde melkproductie, weggegooide melk, verlengde tussenkalftijd en vervroegde afvoer (verkoop voor de slacht en dieren gestorven op het bedrijf)) per koe tijdens één lactatie. Vervolgens is een LCA 
ontwikkeld om de impact van subklinische ketose en gerelateerde ziekten op de uitstoot van broeikasgassen per ton vet en eiwit gecorrigeerde melk ( $\mathrm{kg} \mathrm{CO}_{2}$-equivalenten / t FPCM) te bepalen voor alle processen in de keten tot het product (melk/vlees) het bedrijf verlaat. Meegenomen processen zijn voerproductie, pensfermentatie en mestmanagement. De uitstoot van broeikasgassen nam gemiddeld toe met 21 (2.3\%) $\mathrm{kg} \mathrm{CO}_{2} \mathrm{e} / \mathrm{t}$ FPCM per geval subklinische ketose, variërend van 7 tot 48 . Deze toename van de uitstoot van emissies werd veroorzaakt door een langere tussenkalftijd (31\%), weggegooide melk (30\%), verminderde melkproductie (19\%) en vervroegde afvoer van koeien (20\%). De meeste koeien hadden alleen subklinische ketose (61\%); voor deze koeien nam de uitstoot toe met $8 \mathrm{~kg} \mathrm{CO}_{2} \mathrm{e} / \mathrm{t}$ FPCM, terwijl de afvoer van gestorven koeien op het bedrijf met $463 \mathrm{~kg} \mathrm{CO}_{2} \mathrm{e} / \mathrm{t}$ FPCM toenam. Gevoeligheidsanalyses toonden aan dat variatie van inputparameters een grote invloed hebben op de resultaten.

De ontwikkelde methode in hoofdstuk 2 is in hoofdstuk $\mathbf{3}$ toegepast om de impact van klinische mastitis bij melkkoeien op de uitstoot van broeikasgassen te bepalen. Een dynamisch stochastisch simulatie model is ontwikkeld om de productieverliezen van klinische mastitis voor individuele lactaties te analyseren. Pathogenen die klinische mastitis veroorzaken, werden geclassificeerd in gram-positieve bacteriën, gram-negatieve bacteriën of andere pathogenen. Koeien hadden risico om maximaal drie keer klinische mastitis te krijgen in één lactatie. Op basis van de pariteit en pathogenencombinaties hadden koeien een verminderde melkproductie, weggegooide melk, verlengde tussenkalftijd en een verhoogd risico op vervroegde afvoer. Met behulp van LCA is het effect van klinische mastitis op de uitstoot van broeikasgassen bepaald. De uitstoot van broeikasgassen nam gemiddeld toe met 58 (6,2\%) $\mathrm{kg} \mathrm{CO}_{2} \mathrm{e} / \mathrm{t}$ FPCM per geval van klinische mastitis, variërend tussen 18 tot 174. Deze toename werd veroorzaakt door vervroegde afvoer (39\%), weggegooide melk (38\%), verminderde melkproductie (17\%) en verlengde tussenkalftijd (6\%). De broeikasgasemissies stegen met $48 \mathrm{~kg} \mathrm{CO}_{2} \mathrm{e} / \mathrm{t}$ FPCM voor koeien met één geval van klinische mastitis, met $69 \mathrm{~kg} \mathrm{CO}_{2} \mathrm{e} / \mathrm{t}$ FPCM voor koeien met twee gevallen van klinische mastitis en met $92 \mathrm{~kg} \mathrm{CO} 2 \mathrm{e} / \mathrm{t}$ FPCM voor koeien met drie gevallen van klinische mastitis. Gevoeligheidsanalyses lieten zien dat het risico van vervroegde afvoer en emissies gerelateerd aan het fokken van vaarzen een belangrijk effect had op de resultaten.

In Hoofdstuk 4 is de impact van klauwaandoeningen bij melkkoeien op de uitstoot van broeikasgassen bepaald. Een soortgelijk dynamisch stochastisch simulatiemodel werd ontwikkeld als in hoofdstuk 2 en 3 om de dynamiek van drie soorten klauwaandoeningen (mortellaro, wittelijnaandoeningen en zoolzweren) en de bijbehorende productieverliezen binnen één lactatie 
te bepalen (verminderde melkproductie, verlengde tussenkalftijd en vervroegde afvoer). Vervolgens is een LCA uitgevoerd om de impact van de drie klauwaandoeningen op de uitstoot van broeikasgassen te bepalen. De uitstoot van broeikasgassen nam gemiddeld toe met $14(1,5 \%) \mathrm{kg}$ $\mathrm{CO}_{2} \mathrm{e} / \mathrm{t}$ FPCM per klauwaandoening (mortellaro, wittelijnaandoeningen en zoolzweren gecombineerd), variërend tussen 3 tot 71 . Deze toename werd veroorzaakt door vervroegde afvoer (39\%), verminderde melkproductie (34\%) en verlengde tussenkalftijd (17\%). De uitstoot van broeikasgassen nam gemiddeld toe met $4(0,4 \%) \mathrm{kg} \mathrm{CO}_{2} \mathrm{e} / \mathrm{t}$ FPCM per geval van mortellaro, met 39 (4,3\%) $\mathrm{kg} \mathrm{CO}_{2} \mathrm{e} / \mathrm{t}$ FPCM per geval van wittelijnaandoeningen en met 33 (3,6\%) $\mathrm{kg} \mathrm{CO}_{2} \mathrm{e} / \mathrm{t}$ FPCM per geval van zoolzweren.

In Hoofdstuk 5 zijn de economische gevolgen van subklinische ketose bepaald. Het dynamische stochastische simulatiemodel ontwikkeld in hoofdstuk 2 werd gebruikt om productieverliezen te schatten. Vervolgens werden de kosten geschat op basis van een verminderde melkproductie, weggegooide melk, behandelingskosten, verlengde tussenkalftijd en vervroegde afvoer van koeien. De totale kosten van subklinische ketose bedroegen $€$ 130 per geval per jaar, variërend tussen $€ 39$ tot $€_{348}$. Totale kosten van subklinische ketose per geval per jaar werden bepaald door een verlengde tussenkalftijd (36\%), verminderde melkproductie (24\%), behandelingskosten (19\%), weggegooide melk (14\%) en vervroegde afvoer (6\%). De meeste koeien met subklinische ketose hadden alleen subklinische ketose (61\%) en de kosten waren $€ 58$ per geval per jaar. Resultaten van de gevoeligheidsanalyse lieten zien dat de incidentie van de ziekte, de kans op vervroegde afvoer, de relaties van subklinische ketose met andere ziekten en de melkprijs resulteerden in een grote variatie in de kosten van subklinische ketose.

In hoofdstuk 6 worden methodische keuzes en praktische handvatten bediscussieerd. De discussie toonde het belang van variatie in het model, leeftijd van koeien, verschillende pathogenen en vormen van ziekten, en het analyseren van de effecten van verschillende productieparameters (bijvoorbeeld afvoer, reproductie). Betere gegevens over de prevalentie van ziekten, relaties tussen ziektes, het effect van ziekten op productie, broeikasgasemissies gerelateerd aan de productie van voer en mestbeheer, kunnen de resultaten preciezer maken.

In de discussie wordt het effect van de verschillende ziektes op de uitstoot van broeikasgassen per jaar vergeleken. Een geval van subklinische ketose verhoogde de uitstoot van broeikasgassen met $176 \mathrm{~kg} \mathrm{CO}_{2} \mathrm{e}$ per jaar, klinische mastitis met $498 \mathrm{~kg} \mathrm{CO}_{2} \mathrm{e}$ per jaar, mortellaro met $30 \mathrm{~kg} \mathrm{CO}_{2} \mathrm{e}$ per jaar, wittelijnaandoeningen met $336 \mathrm{~kg} \mathrm{CO}_{2} \mathrm{e}$ per jaar en zoolzweren met $280 \mathrm{~kg} \mathrm{CO}_{2} \mathrm{e}$ per jaar. 
Afvoer van koeien en weggegooide melk hebben de grootste bijdrage aan de toename van broeikasgassen. Prevalentie, type ziekte en bedrijfsmanagement (bijvoorbeeld afvoer van koeien, voer- en mestmanagement) hebben invloed op het effect van productieverliezen op broeikasgasemissies. Daarom zijn specifieke bedrijfsanalyses nodig om het effect van ziekten op broeikasgasemissies op een specifiek melkveebedrijf te bepalen.

Het verminderen van ziekten bij koeien kan gunstig zijn vanuit economisch perspectief en kan bijdragen aan een afname van broeikasgasemissies. Ziekten hebben verhoudingsgewijs een groter effect op economische gevolgen dan op de uitstoot van broeikasgassen. De bijdrage van productieverliezen verschilde vanuit broeikasgasemissies- en economisch oogpunt. Een vermindering van de melkproductie had het grootste effect op de economische gevolgen, terwijl afvoer van koeien en weggegooide melk het grootste effect hadden op de toename van de uitstoot van broeikasgassen.

Het huidige doel van de Nederlandse regering is om in 2030 de uitstoot van broeikasgassen door de landbouw te verminderen met 3,5 Mton, waarvan 1,0 Mton in de tuinbouw. Op basis van dit proefschrift kan worden geconcludeerd dat ziekten bij melkkoeien de broeikasgasemissies met ongeveer 0,4 Mton per jaar verhogen. Ziekten hebben de potentie om 15\% bij te dragen aan het Nederlandse overheidsdoel. Beleid ter vermindering van de uitstoot van broeikasgassen in de veehouderij (inclusief de zuivelsector) zou veehouders kunnen stimuleren om een bijdrage te leveren. Een nationaal programma om niet alleen meer bekendheid te geven aan de impact van verschillende ziekten bij koeien, maar ook de preventie en signalering ervan zou kunnen helpen om ziekten en broeikasgasemissies te verminderen. Het blijft echter de vraag wie de kosten moet dragen van een dergelijk programma. Andere strategieën om broeikasgasemissies te verminderen zijn niet altijd kosteneffectief. Het verminderen van ziekten kan echter zowel de uitstoot van broeikasgassen verminderen als het inkomen van de boer verhogen en het dierenwelzijn verbeteren. Daarom kan het verminderen van ziekten bij melkkoeien bijdragen aan duurzame ontwikkeling van de zuivelsector. 


\section{Dankwoord}

Vier jaar later, opeens is het PhD leven voorbij. Het was een bijzondere tijd! Duurzaamheid is een ontzettend belangrijk en leuk onderwerp. Ik ben dan ook erg blij en dankbaar dat ik onderzoek naar dit onderwerp heb kunnen doen. Aangezien mijn onderzoek een model studie is, heb ik deze tijd vooral achter de computer doorgebracht. Een heleboel mensen hebben mij (in)direct geholpen in deze periode. Ik wil hen dan ook graag bedanken.

Imke, wij namen beiden een gok vier jaar geleden omdat het nog onzeker was of dit project rond zou komen. Ik ben blij dat we die gok samen namen. Ondanks je drukke agenda, had je altijd tijd voor mijn onderzoek. Jouw enthousiasme, zien en denken in mogelijkheden hebben mij erg geholpen. Daarnaast heeft jouw kritische blik op methodiek en manuscripten mij een hoop geleerd. Ik kon mij geen betere dagelijkse begeleiders wensen dan Eddie en Corina. Eddie, jij ziet elk detail in manuscripten. Soms had ik het idee dat jij al een antwoord had gestuurd, voordat ik mijn mail had verzonden. Jouw deur stond altijd open voor een kort praatje en niet alleen om over onderzoek te praten. Vanaf nu zal je waarschijnlijk zelf de sportuitslagen weer in de gaten moeten houden. Corina, jouw kennis van melkveehouderij en levenscyclusanalyse hebben mij erg geholpen. Jouw precisie in het ontwikkelen van modellen brachten mij verder en jij hielp mij milieu analyses te begrijpen.

The first two years of my research were in cooperation with Elanco Animal Health. Geert, Maria, Roger, Rolf, and Theo, thank you for supporting this project. Geert, Roger, and Maria, thank you for the interesting discussions about subclinical ketosis and greenhouse gases. I also would like to thank George Tice, Douglas Miller, Christian Lofberg, Thomas Erlacher, Mike Overton, Mike Steele, Jan Arie Koorevaar, and Tom Vanholder for supporting this thesis.

Henk Hogeveen, bedankt dat je mee wilde denken en schrijven over subklinische ketose en economie.

Mijn PhD tijd heb ik bij de Animal Production Systems groep doorgebracht. Mijn PhD kamer heb ik 4 jaar gedeeld met vooral vrouwen. Linda, Heleen, Evelyne, Abigail, Ollie, Margret bedankt voor de leuke gesprekken, appie wandelingen, enz, en het aanhoren van mijn sportverhalen ;). Akke, wij begonnen tegelijk en ronden tegelijk onze $\mathrm{PhD}$ af. Het was gezellig om jou als buurvrouw te hebben. Daarnaast hebben jouw parate kennis en ideeën mij erg geholpen. Bedankt voor al onze discussies over modelleren, broeikasgassen en het leven. 
142 | Dankwoord

Tevens wil ik alle andere APS collega's bedanken voor de gezelligheid en discussies: Cindy, Iris, Aart, Louise, Laura, Hannah, Raimon, Brain, Evelien, Fokje, Theo, Lia, Simon, Windi, Titis.

Meerdere studenten hebben hun afstudeeropdracht bij mij gedaan. Gerben, Guilherme, Esmée, Joanne, en Céline. Bedankt voor jullie enthousiasme en de inzichten die jullie mij hebben gegeven. Buiten mijn werk wil ik meerdere personen bedanken. Kenny, David, Laurens, Oeds, Gerhard, Ralf, bedankt voor onze voetbalweekendjes, potjes PES, Star Wars avonden, Axis and Allies dagen, de Zaaier, vele discussies, enz, en vooral de gezelligheid! Jullie oprechte interesse in mijn onderzoek, maar vooral in mij als persoon waardeer ik erg! Kenny, ik vind je levensinstelling mooi en ik ben blij dat je mijn paranimf wilt zijn.

Ik heb afgelopen jaren met veel plezier getafeltennist bij SKF Veenendaal. Brenda en Pieter, bedankt voor alle leuke seizoenen en kampioenschappen. Theo, bedankt voor de trainingen en gezelligheid in de auto. Rouke en Hans, we spelen al jaren niet meer in hetzelfde team maar toch blijven we elkaar buiten tafeltennis om zien. Ik vind het leuk dat we contact hebben gehouden en bijpraten onder het genot van een etentje, biertje, of (slechte) voetbalwedstrijd.

Anne Nijland, bedankt voor het ontwerpen van de voorkant van mijn $\mathrm{PhD}$ boekje.

Ook wil ik mijn broers en (schoon)familie bedanken voor hun steun en interesse in mijn onderzoek. Pap en mam, bedankt voor alle kansen en steun die jullie mij altijd gegeven hebben. Leuk dat duurzaamheid ook jullie interesse heeft.

Ten slotte wil ik mijn vrouw bedanken. Lieve Willemijn, jij zorgt voor een goede balans tussen werk en leven. Bedankt voor het steunen afgelopen 4 jaar; samen met jou zijn, dat is echt belangrijk.

Pim Mostert

Wageningen, April 2018 


\section{About the author}

Pim Mostert was born on the $17^{\text {th }}$ of September 1986 in Leiden. After obtaining his BSc in Animal Sciences with a minor in economics of animal production, he started his MSc in Animal Sciences at Wageningen University. During his Msc, he also started the European Master in Animal Management, for which he studied in Toulouse for four months. His MSc thesis entitled 'Understanding the behaviour of broiler farmers and chain partners towards more animal friendly production' was conducted at the Animal Production

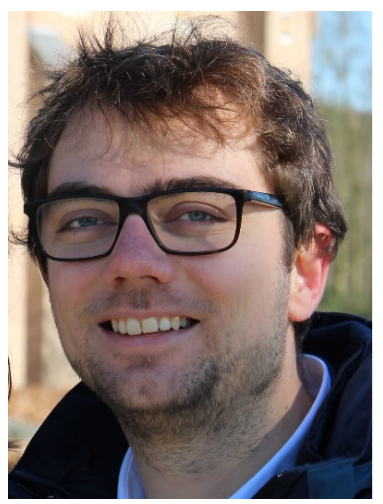
Systems group of Wageningen University and Wageningen Economic Research (Landbouw Economisch Instituut). His internship 'Quantifying methane emission from dairy cattle in Bangladesh and Kenya' was conducted at the Food and Agriculture Organization of the United Nations in Rome. Pim obtained his MSc degree in July 2013.

Pim started his PhD research at the Animal Production systems group in February 2014. In his $\mathrm{PhD}$ thesis, he developed a model and estimated the impact of diseases in dairy cows on greenhouse gas emissions and economic performance. Results of his research were presented at international conferences and were published in peer-reviewed journals. In his free time, Pim likes playing table tennis, soccer, traveling, and reading.

After the completion of his PhD thesis, Pim would like to continue working on sustainability and agriculture. 



\section{Publications}

\section{Refereed scientific journals}

Kok, A., Van Middelaar, C.E., Mostert, P.F., Van Knegsel, A.T.M., Kemp, B., De Boer, I.J.M., Hogeveen, H., 2017. Effects of dry period length on production, cash flows and greenhouse gas emissions of the dairy herd: A dynamic stochastic simulation model. PLoS ONE 12, e0187101.

Mostert, P.F., Bokkers, E.A.M., Van Middelaar, C.E., Hogeveen, H., De Boer, I.J.M., 2018. Estimating the economic impact of subclinical ketosis in dairy cattle using a dynamic stochastic simulation model. Animal 12, 145-154.

Mostert, P.F., van Middelaar, C.E., Bokkers, E.A.M., de Boer, I.J.M., 2018. The impact of subclinical ketosis in dairy cows on greenhouse gas emissions of milk production. J Clean Prod. $171,773-782$.

Mostert, P.F., Bokkers, E.A.M., de Boer, I.J.M., van Middelaar, C.E. The impact of clinical mastitis in dairy cows on greenhouse gas emissions of milk production. Submitted.

Mostert, P.F., van Middelaar, C.E., de Boer, I.J.M., Bokkers, E.A.M. The impact of foot lesions in dairy cows on greenhouse gas emissions of milk production. Submitted. 
146 | Publications

\section{Abstracts in conference proceedings}

Mostert, P.F., Bokkers, E.A.M., van Middelaar, C.E.; de Boer, I.J.M., 2015. Environmental and economic consequences of subclinical ketosis and related diseases in dairy farming. In: Book of abstracts of the Joint Annual Meeting 2015, Orlando, Florida, USA, p. 875-875.

Mostert, P.F., Bokkers, E.A.M., van Middelaar, C.E., de Boer, I.J.M., 2015. Environmental and economic consequences of subclinical ketosis and related diseases in dairy farming. In: Book of Abstracts of the 66th Annual Meeting of the European Federation of Animal Science, August 31September 4, Warsaw, Poland, p. 141-141

Mostert, P. F., Bokkers, E.A.M., van Middelaar, C. E., de Boer, I.J.M., 2016. The impact of subclinical ketosis in dairy cows on greenhouse gas emissions of milk production In: Book of Abstracts of the 1oth international conference on Life Cycle Assessment of Food, October 19-21, Dublin, Ireland, p. 127-132

Mostert, P.F., Bokkers, E.A.M., van Middelaar, C.E., de Boer, I.J.M., 2017. The impact of health problems in dairy cows on greenhouse gas emissions: a case study with mastitis. In Proceedings of the 7th International Conference on the Assessment of Animal Welfare at Farm and Group Level, September 5-8, Ede, the Netherlands, p. 51-51.

Mostert, P., van Middelaar, C., Bokkers, E., de Boer, I, 2017. The impact of mastitis in dairy cows on the carbon footprint of milk. In: Proceedings of the 5th European Buiatrics Forum, October 46, Bilbao, Spain, p. 64-64.

Mostert, P.F., van Middelaar, C.E., Bokkers, E.A.M., de Boer, I.J.M., 2017. How mastitis in dairy cows affects the carbon footprint of milk. Abstracts of the 68th Annual Meeting of the European Federation of Animal Science, August 28 - September 1, Tallinn, Estonia, p. 169-169.

Kok, A., van Middelaar, C.E., Mostert, P.F., van Knegsel, A.T.M., Kemp, B., de Boer, I.J.M., Hogeveen, H., 2017. Economic and environmental impact of dry period length in dairy cows. In: Proceedings of the 7th International Conference on the Assessment of Animal Welfare at Farm and Group Level, September 5-8, Ede, the Netherlands, p. 54-54. 


\section{Education certificate}

\section{Completed training and supervision plan ${ }^{1}$}

\section{The Basic Package (3.o ECTS)}

- WIAS Introduction Course (2014)

- Ethics and Philosophy in Life Sciences (2015)

International conferences (4.8 ECTS)

- ADSA, Orlando, USA (2015)

- $\quad$ EAAP, Warsaw, Poland (2015)

- $\quad$ LCA Food, Dublin, Ireland (2016)

- EBF, Bilbao, Spain (2017)

\section{Seminars and workshops (1.5 ECTS)}

- WIAS Science Day, Wageningen (2014, 2015, 2016, 2017, 2018)

\section{Presentations (8.o ECTS)}

- WIAS Science Day, Wageningen, poster (2015, 2016, 2017)

- ADSA, Orlando, USA, oral (2015)

- $\quad$ EAAP, Warsaw, Poland, oral (2015)

- $\quad$ LCA Food, Dublin, Ireland, oral (2016)

- $\quad$ EBF, Bilbao, Spain, oral (2017)

- WIAS Science Day, Wageningen, oral (2018)

\section{In-Depth Courses (9.0 ECTS)}

- Applied economic modelling for the veterinary sciences, Utrecht University (2014)

- Advanced LCA, Aalborg University, Denmark (2014)

- Environmental impact assessment of livestock systems, Wageningen University (2015)

\section{Professional Skills Support Courses (3.9 ECTS)}

- Techniques for Writing and Presenting a Scientific Paper (2015)

- Presenting with Impact (2016)

- Career Perspectives (2017)

\section{Research Skills Training (6.o ECTS)}

- Preparing own PhD research proposal (2014)

\section{Didactic Skills Training (9.o ECTS)}

- Supervision practicals 'Introduction to Animal Sciences' (2014, 2015, 2016)

- Supervision practicals 'Systems Approach in Animal Sciences' (2016, 2017)

- Thesis supervision of 4 BSc and 1 MSc students (2014-2018)

\section{Total: 45.2 ECTS}

${ }^{1}$ With the activities listed the PhD candidate has complied with the educational requirements set by the Graduate School of Wageningen Institute of Animal Sciences (WIAS) of Wageningen University \& Research, which comprises a minimum of 30 ECTS (European Credit Transfer and accumulation System). One ECTS equals a study load of 28 hours. 
148 | 


\section{Colophon}

The research described in this thesis was partly financed by Elanco Animal Health.

Cover design and illustrations at start of each chapter by Anne Nijland

Illustrations figure 2 in chapter 1 by Birgit Boogaard. Kuwona - Advice, Training \& illustrations Printed by GVO drukkers \& vormgevers B.V., Ede 
150 | 




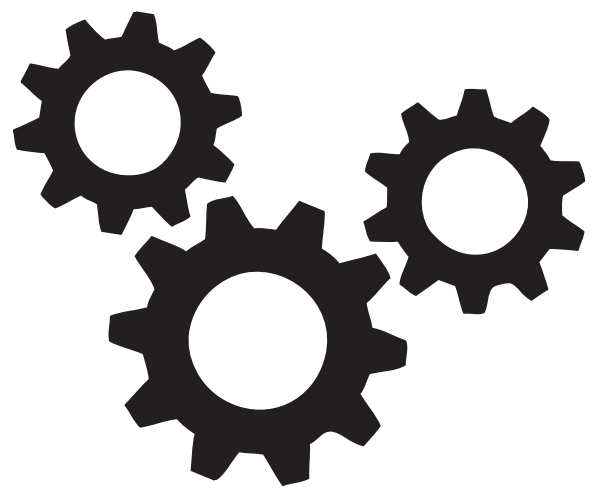

